\title{
Toekomst in techniek? : waarde-orientatie, beeldvorming en keuze-intenties van jongeren
}

Citation for published version (APA):

Willems, E. J. T. A., \& de Grip, A. (1993). Toekomst in techniek? : waarde-orientatie, beeldvorming en keuze-intenties van jongeren. Researchcentrum voor Onderwijs en Arbeidsmarkt, Faculteit der Economische Wetenschappen. ROA Reports No. 7 https://doi.org/10.26481/umarep.1993007

Document status and date:

Published: 01/01/1993

DOI:

10.26481/umarep.1993007

Document Version:

Publisher's PDF, also known as Version of record

\section{Please check the document version of this publication:}

- A submitted manuscript is the version of the article upon submission and before peer-review. There can be important differences between the submitted version and the official published version of record.

People interested in the research are advised to contact the author for the final version of the publication, or visit the DOI to the publisher's website.

- The final author version and the galley proof are versions of the publication after peer review.

- The final published version features the final layout of the paper including the volume, issue and page numbers.

Link to publication

\footnotetext{
General rights rights.

- You may freely distribute the URL identifying the publication in the public portal. please follow below link for the End User Agreement:

www.umlib.nl/taverne-license

Take down policy

If you believe that this document breaches copyright please contact us at:

repository@maastrichtuniversity.nl

providing details and we will investigate your claim.
}

Copyright and moral rights for the publications made accessible in the public portal are retained by the authors and/or other copyright owners and it is a condition of accessing publications that users recognise and abide by the legal requirements associated with these

- Users may download and print one copy of any publication from the public portal for the purpose of private study or research.

- You may not further distribute the material or use it for any profit-making activity or commercial gain

If the publication is distributed under the terms of Article $25 \mathrm{fa}$ of the Dutch Copyright Act, indicated by the "Taverne" license above, 


\section{TOEKOMST IN TECHNIEK?}

Waarde-oriëntatie, beeldvorming en keuze-intenties van jongeren

ROA-R-1993/7

E.J.T.A. Willems

A. de Grip

RESEARCHCENTRUM VOOR ONDERWIJS EN ARBEIDSMARKT

Rijksuniversiteit Limburg

Faculteit der Economische Wetenschappen

Maastricht, september 1993 
CIP-GEGEVENS KONINKLIJKE BIBLIOTHEEK, DEN HAAG

Willems, E.J.T.A.

Toekomst in techniek? : waarde-oriëntatie, beeldvorming en keuze-intenties van jongeren / E.J.T.A. Willems, A. de Grip. - Maastricht: Researchcentrum voor Onderwijs en Arbeidsmarkt, Rijksuniversiteit Limburg, Faculteit der Economische Wetenschappen. - Fig., tab. - (ROA-R1993/7)

Met lit. opg.

ISBN 90-5321-100-4

Trefw.: arbeidsmarkt; technici / onderwijs en arbeidsmarkt; Nederland. 
INHOUDSOPGAVE

Bladzijde

OVERZICHT VAN TABELLEN EN FIGUREN

VERANTWOORDING

v

Deel I: Doelstelling en opzet van het onderzoek

1. INLEIDING 3

1.1. Doelstelling van het onderzoek 3

1.2. Opzet van het rapport 6

2. OPZET VAN DE ENOUÊTE

2.1. Steekproeftrekking en respons 8

$\begin{array}{ll}\text { 2.2. Herweging van het databestand } & 9\end{array}$

Deel II: Waardering voor techniek

3. WAARDERING: INTERESSE EN HOUDING 15

3.1. Informatie over techniek 15

3.2. Waarderingsschalen met betrekking tot techniek 16

$\begin{array}{ll}\text { 3.3. Interesse voor techniek } & 17\end{array}$

3.4. Consequenties van techniek 21

3.5. Meisjes en techniek 25

4. WAARDERING VAN ENKELE SPECIFIEKE TECHNOLOGIEËN 29

5. DE WAARDERING VOOR TECHNIEK IN VOGELVLUCHT 37

Deel III: Imago van het technisch onderwijs

6. DE MOEILIJKHEIDSGRAAD VAN DE OPLEIDING 43

6.1. De bepaling van het relatieve imago van het technisch onderwijs 43

6.2. De moeilijkheidsgraad van de technische opleiding 44

7. ARBEIDSMARKTPOSITIE: WERK EN INKOMEN 48

7.1. Kans op werk 48

7.2. Inkomen $\quad 50$

7.3. De arbeidsmarktpositie van het technisch onderwijs 53 
8. KWALITATIEVE ASPECTEN VAN HET WERK 56

8.1. Zwaar werk 56

8.2. Stress 58

8.3. Vuil werk 60

8.4. Saai werk 62

8.5. Zelfstandigheid 64

8.6. Kwalitatieve aspecten van het werk van technisch opgeleiden 67

9. HET IMAGO VAN HET TECHNISCH ONDERWIJS IN VOGELVLUCHT 69

Deel IV: De keuze voor techniek

10. DE KEUZE NA HET BASISONDERWIJS EN DE VAKKENPAKKETKEUZE IN HET ALGEMEEN VOORTGEZET ONDERWIJS

10.1. De keuze na het basisonderwijs

10.2. De vakkenpakketkeuze in het algemeen voortgezet onderwijs 77

11. DE KEUZE NA DE HUIDIGE OPLEIDING 80

11.1. De keuze tussen leren en werken 80

11.2. De keuze voor techniek 82

12. DE KEUZE VOOR TECHNIEK IN VOGELVLUCHT 95

Deel V: Bes/uit

13. SAMENVATTING EN BELEIDSIMPLICATIES 103

$\begin{array}{ll}\text { LITERATUUR } & 111\end{array}$

BIJLAGEN:

$\begin{array}{ll}\text { A. VRAGENLIJSTEN JEUGD EN TECHNIEK } & 113\end{array}$

B. BETROUWBAARHEID VAN DE TECHNIEK-WAARDERINGSSCHALEN 127

C. OVERZICHT VAN GEBRUIKTE VARIABELEN IN DE MULTIVARIATE ANALYSES

D. ENKELE AANVULLENDE TABELLEN 


\section{OVERZICHT VAN TABELLEN EN FIGUREN}

Bladzijde

Figuur 1.1. Onderzoeksmodel

Tabel 2.1. Aantal benaderde scholen en respons van de scholen per opleidingscategorie

Tabel 2.2. Samenstelling van de respons van de leerlingen naar $\begin{array}{lr}\text { opleidingscategorie en geslacht } & 9\end{array}$

Tabel 2.3. Herwogen databestand naar opleidingscategorie en regio 10

Tabel 2.4. Herwogen databestand naar opleidingscategorie en geslacht 10

Tabel 3.1. Informatiebronnen over techniek naar opleidingscategorie en geslacht 15

Tabel 3.2. Interesse voor techniek naar geslacht 17

$\begin{array}{lll}\text { Figuur 3.1. Interesse voor techniek naar opleidingscategorie en geslacht } & 18\end{array}$

Tabel 3.3. $\quad$ Schattingsresultaten van een multivariate analyse van de interesse voor techniek naar opleidingscategorie (standaardfouten tussen haakjes) 20

Tabel 3.4. Houding ten opzichte van de consequenties van technologische ontwikkelingen naar geslacht

Figuur 3.2. Houding ten opzichte van de consequenties van technologische ontwikkelingen naar opleidingscategorie en geslacht

Tabel 3.5. Schattingsresultaten van een multivariate analyse van de houding ten opzichte van de consequenties van technologische ontwikkelingen naar opleidingscategorie (standaardfouten tussen haakjes) 24

Tabel 3.6. Houding ten opzichte van meisjes en techniek naar geslacht 25

Figuur 3.3. Houding ten opzichte van meisjes en techniek naar opleidingscategorie en geslacht 26

Tabel 3.7. Schattingsresultaten van een multivariate analyse van de houding ten opzichte van meisjes en techniek naar opleidingscategorie (standaardfouten tussen haakjes)

Tabel 4.1. Waardering van 'nieuwe apparaten' naar opleidingscategorie en geslacht

Tabel 4.2. Waardering van informatietechnologie naar opleidingscategorie en geslacht

Tabel 4.3. Kennis en waardering van kernenergie naar opleidingscategorie en geslacht

Tabel 4.4. Kennis en waardering van milieutechnologie naar opleidingscategorie en geslacht 33

Figuur 4.1. De interesse voor enkele technologische ontwikkelingen naar geslacht 34 Figuur 4.2. De inschatting van de economische gevolgen van enkele technologische ontwikkelingen naar geslacht 
Figuur 4.3. De inschatting van de gevolgen voor de werkloosheid van enkele technologische ontwikkelingen naar geslacht

Figuur 4.4. De waardering van enkele technologische ontwikkelingen naar geslacht

Tabel 6.1a-e. Verwachte moeilijkheidsgraad van vervolgopleidingen

Figuur 6.1. Het relatieve imago van het technisch onderwijs met betrekking tot de moeilijkheidsgraad van de opleiding naar opleidingscategorie en geslacht

Tabel 6.2. Schattingsresultaten van een multivariate analyse van de gepercipieerde relatieve moeilijkheidsgraad van de technische opleiding naar opleidingscategorie (standaardfouten tussen haakjes)

Tabel 7.1a-e. Verwachte kans op werk van vervolgopleidingen 138

Figuur 7.1 . Het relatieve imago van het technisch onderwijs met betrekking tot de kans op werk naar opleidingscategorie en geslacht

Tabel 7.2a-e. Verwachte inkomensverhoudingen van vervolgopleidingen

Figuur 7.2. Het relatieve imago van het technisch onderwijs met betrekking tot de kans op een hoog inkomen naar opleidingscategorie en geslacht

Tabel 7.3. Schattingsresultaten van een multivariate analyse van de gepercipieerde relatieve arbeidsmarktpositie van technisch opgeleiden naar opleidingscategorie (standaardfouten tussen haakjes)

Tabel 8.1a-e. Verwachte kans op lichamelijk zwaar werk van vervolgopleidingen

Figuur 8.1. Het relatieve imago van het technisch onderwijs met betrekking tot de kans op een lichamelijk zwaar beroep naar opleidingscategorie en geslacht

Tabel 8.2. Aandeel werkenden dat aangeeft dat lichamelijk zwaar werk hoofdzakelijk tot hun werk behoort naar opleidingsniveau en -richting

Tabel 8.3a-e. Verwachte kans op een beroep met veel stress van vervolgopleidingen143 Figuur 8.2. Het relatieve imago van het technisch onderwijs met betrekking tot de kans op een beroep met veel stress naar opleidingscategorie en geslacht

Tabel 8.4a-e. Verwachte kans op een beroep met vaak vuil werk van vervolgopleidingen

Figuur 8.3. Het relatieve imago van het technisch onderwijs met betrekking tot de kans op een beroep met vaak vuil werk naar opleidingscategorie en geslacht

Tabel 8.5. Aandeel werkenden dat aangeeft dat vuil werk hoofdzakelijk tot hun werk behoort naar opleidingsniveau en -richting

Tabel 8.6a-e. Verwachte kans op een beroep met vaak saai werk van vervolgopleidingen 
Figuur 8.4. Het relatieve imago van het technisch onderwijs met betrekking tot de kans op een beroep met vaak saai werk naar opleidingscategorie en geslacht

Tabel 8.7. Aandeel werkenden dat aangeeft dat saai werk hoofdzakelijk tot hun werk behoort naar opleidingsniveau en -richting

Tabel 8.8a-e. Verwachte kans op een beroep met veel zelfstandigheid van vervolgopleidingen

Figuur 8.5. Het relatieve imago van het technisch onderwijs met betrekking tot de kans op een beroep met veel zelfstandigheid naar opleidingscategorie en geslacht

Tabel 8.9. Aandeel werkenden dat aangeeft dat zelfstandig werk hoofdzakelijk tot hun werk behoort naar opleidingsniveau en -richting

Tabel 8.10. Schattingsresultaten van een multivariate analyse van de gepercipieerde relatieve kwalitatieve aspecten van het werk van technisch opgeleiden naar opleidingscategorie (standaardfouten tussen haakjes)

Tabel 10.1. Advies van de basisschool naar opleidingscategorie en geslacht

Tabel 10.3. Informatiebronnen over de keuze van de huidige opleiding naar opleidingscategorie en geslacht

Tabel 10.4. Spijt van de keuze voor de huidige opleiding naar opleidingscategorie en geslacht

Tabel 10.5. Keuze van het 'doorstroomprofiel' door MAVO- en HAVO/VWOleerlingen naar geslacht

Tabel 10.6a. Redenen voor het al dan niet kiezen van het vak frans door MAVO- en HAVO/VWO-leerlingen naar geslacht

Tabel 10.6b. Redenen voor het al dan niet kiezen van het vak geschiedenis door MAVO- en HAVO/VWO-leerlingen naar geslacht

Tabel 10.6c. Redenen voor het al dan niet kiezen van het vak wiskunde door MAVO- en HAVO/VWO-leerlingen naar geslacht

Tabel 10.6d. Redenen voor het al dan niet kiezen van het vak natuurkunde door MAVO- en HAVO/VWO-leerlingen naar geslacht

Tabel 10.6e. Redenen voor het al dan niet kiezen van het vak economie door MAVO- en HAVO/VWO-leerlingen naar geslacht

Tabel 11.1. Plannen na de huidige opleiding naar opleidingscategorie en geslacht 80 Tabel 11.2a-e. Keuze voor een vervolgopleiding naar geslacht 156 Tabel 11.3. Keuze voor een beroep naar opleidingscategorie en geslacht $\quad 158$

Figuur 11.1. De keuze voor techniek naar opleidingscategorie en geslacht

Tabel 11.4. De keuze voor verschillende vervolgrichtingen naar geslacht en opleidingsniveau van de ouders/verzorgers (rijpercentages per geslacht) 83 
Tabel 11.5. De keuze voor verschillende vervolgrichtingen naar geslacht en beroepsrichting van de ouders/verzorgers (rijpercentages per geslacht) 84

Tabel 11.6. De keuze voor verschillende vervolgrichtingen naar geslacht en een algemene typering van de leerling (rijpercentages per geslacht)

Tabel 11.7. De keuze voor verschillende vervolgrichtingen door MAVO- en HAVO/VWO-leerlingen naar geslacht en gemiddelde rapportcijfers voor A- en B-vakken (rijpercentages per geslacht)

Tabel 11.8. De keuze voor verschillende vervolgrichtingen door MAVO- en HAVO/VWO-leerlingen naar geslacht en de subjectieve inschatting van de eigen capaciteiten voor A- en B-vakken (rijpercentages per geslacht)

Tabel 11.9. De relatie tussen de rapportcijfers en de subjectieve inschatting van de eigen capaciteiten voor A- en B-vakken voor MAVO- en HAVO/VWO-leerlingen naar geslacht (rijpercentages per geslacht)

Tabel 11.10. De keuze voor verschillende vervolgrichtingen naar geslacht en de waardering voor techniek (rijpercentages per geslacht)

Tabel 11.11. De keuze voor verschillende vervolgrichtingen naar geslacht en de verwachte moeilijkheidsgraad van het technisch onderwijs (rijpercentages per geslacht)

Tabel 11.12. De keuze voor verschillende vervolgrichtingen naar geslacht en de verwachte arbeidsmarktpositie van technisch opgeleiden (rijpercentages per geslacht)

Tabel 11.13. De keuze voor verschillende vervolgrichtingen naar geslacht en de verwachte kwalitatieve aspecten van het werk van technisch opgeleiden (rijpercentages per geslacht)

Tabel 11.14. Schattingsresultaten van een multivariate analyse van de keuze voor de technische richting door MAVO- en HAVO/VWO-leerlingen (probitmodel; standaardfouten tussen haakjes)

Figuur 12.1. De trechter naar techniek per geslacht 96

Figuur 12.2. De stromen naar techniek

Tabel 13.1. Implicaties van veranderingen in het keuzegedrag met betrekking tot de technische richting

Tabel B.1. Gemiddelde, standaarddeviatie en item-rest-correlatie per item

Tabel B.2. Cronbach's $a$ voor de verschillende schalen

Tabel C.1. Overzicht van gebruikte variabelen in de multivariate analyses 


\section{VERANTWOORDING}

In dit rapport wordt verslag gedaan van het onderzoek 'Jeugd en Techniek' dat door het Researchcentrum voor Onderwijs en Arbeidsmarkt (ROA) in opdracht van het Ministerie van Economische Zaken, directie Algemeen Technologiebeleid, in het kader van het programma 'Technologie en Samenleving' is verricht. Het globale doel van de studie was het in beeld brengen van het maatschappelijk draagvlak voor technologische vernieuwing onder jongeren. Daarvoor is een enquête gehouden onder ruim 2.000 leerlingen van het voortgezet onderwijs, waarin vooral werd ingegaan op de waardering ten aanzien van techniek, het relatieve imago van het technisch onderwijs en het werkveld van technisch opgeleiden en de keuze-intenties voor de technische vakrichting. Naast deze uitgebreide rapportage is er tevens een meer samenvattend rapport verschenen in de door het Ministerie van Economische Zaken uitgebrachte reeks 'Beleidsstudies Technologie Economie' (Willems en De Grip, 1993).

Het onderzoek werd uitgevoerd door drs. E.J.T.A. Willems en dr. A. de Grip, met medewerking van drs. H. Berendsen. Dr. R.K.W. van der Velden verleende enkele belangrijke adviezen. Bij de verwerking van de gegevens werd assistentie verleend door A.M. Kleijnen en M.E.C. Reiners. Verder werd belangrijk ondersteunend werk verricht door M.M.J.L. Boere en L.M.S. Romans.

Een woord van dank wordt gericht aan de leden van de ten behoeve van dit onderzoek samengestelde begeleidingscommissie. Deze commissie bestond uit de volgende leden:

mr. H.W.H. van Bergen

Ministerie van Economische Zaken

drs. L. Dalderup

Stichting Publieksvoorlichting voor Wetenschap en Techniek (PWT)

drs. C.A. Holland

Ministerie van Economische Zaken (tot 1 november 1992)

dr. M.J. Meesters

Regioplan Onderwijs en Arbeidsmarkt

P.W. van Voorthuijsen (voorzitter) Ministerie van Economische Zaken

drs. R.A.M. van de Winkel Compaz Midden-Nederland

Voorts is een dankwoord aan alle deelnemende scholen en leerlingen op zijn plaats. Zonder hun medewerking was dit rapport uiteraard nooit tot stand gekomen. Verder gaat onze dank uit naar dhr. J.M.M. Mertens (LTS St. Joseph, Cadier en Keer), mevr. M. Meys (Scholengemeenschap Savelsbos, Gronsveld), dhr. F.L.G. Moers (Scholengemeenschap Trajectum, Maastricht) en dhr. J.W.M. Raedts (St. Maartenscollege, Maastricht). Zij waren allen zeer behulpzaam bij het beantwoorden van specifieke vragen met betrekking tot de keuzemogelijkheden en andere bijzonderheden van de diverse onderwijsvormen. Daarnaast is dank verschuldigd voor hun commentaar op de concept-vragenlijst en voor hun medewerking bij het organiseren van een proefenquête onder hun leerlingen. Tot slot wordt een dankwoord gericht aan de Organisatie voor Strategisch Arbeidsmarktonderzoek (OSA) voor het ter beschikking stellen van enkele gegevens van het arbeidsaanbodpanel. 

DEEL I

DOELSTELLING EN OPZET VAN HET ONDERZOEK 



\section{INLEIDING}

\subsection{Doelstelling van het onderzoek}

Een kennisintensieve technologische ontwikkeling wordt vaak als de motor voor de economische groei van ons land gezien (zie bijvoorbeeld Ministerie van Economische Zaken, 1990). De laatste jaren wordt er echter nogal eens op gewezen dat door de verminderde belangstelling voor het technisch onderwijs de (kennisintensieve) economische ontwikkeling van ons land dreigt te worden beperkt. Op verscheidene segmenten van de arbeidsmarkt bestaan er nu reeds tekorten aan technici, terwijl op met name de langere termijn deze tekorten naar verwachting sterk zullen toenemen (zie bijvoorbeeld Researchcentrum voor Onderwijs en Arbeidsmarkt, 1992a, Centraal Planbureau, 1992 en Berendsen, De Grip en Willems, 1991). In de notitie Technologie \& Samenleving (Ministerie van Economische Zaken, 1991; zie ook Holland, 1992) wordt aangegeven dat het technologiebeleid niet langer alleen moet zijn gericht op het stimuleren van technologische vernieuwing in bedrijven, maar ook op de bevordering van de integratie van technologie in de samenleving. In feite gaat het daarbij om het verbreden van het maatschappelijk draagvlak voor technologische vernieuwingen.

Om meer richting te kunnen geven aan de invulling van het overheidsbeleid op dit punt, is een adequate monitoring van de ontwikkeling van dit maatschappelijk draagvlak vanzelfsprekend een eerste vereiste. Daarbij is het belangrijk om een onderscheid te maken tussen enerzijds de publiekshouding ten aanzien van wetenschap en techniek en anderzijds de belangstelling voor technische beroepen of het technisch onderwijs. Het eerste is van groot belang voor de acceptatiebereidheid van de samenleving van technologische vernieuwingen, hetgeen mede bepalend is voor de vraagzijde van 'de markt voor technologische vernieuwing'. Het laatste is essentieel voor de aanbodzijde van deze markt. Vanuit zowel innovatie- als diffusie-oogpunt is een adequaat geschoolde beroepsbevolking immers van doorslaggevend belang voor het bewerkstelligen van verdergaande technologische vernieuwingen.

De globale hoofddoelstelling van dit onderzoek - het in beeld brengen van het maatschappelijk draagvlak voor technologische vernieuwing - kan op een tweetal punten worden geconcretiseerd. In de eerste plaats wordt de doelgroep nader afgebakend. Aangezien het technisch potentieel van de samenleving reeds in grote mate tijdens de periode waarin men initieel onderwijs volgt wordt bepaald, is het onderzoek toegespitst op jongeren van 14 à 15 jaar. Bovendien zijn door de toespitsing op deze doelgroep de onderzoeksresultaten, in ieder geval ten aanzien van de aanbodzijde van de markt voor technologische vernieuwing, relevant voor de te verwachten toekomstige ontwikkelingen. Een tweede concretisering heeft betrekking op het maatschappelijk draagvlak. Op dit punt worden de volgende drie elementen onderscheiden:

- de waarde-oriëntatie ten aanzien van techniek, c.q. technologische vernieuwingen;

- de beeldvorming ten aanzien van het technisch onderwijs en het werkveld van technisch opgeleiden;

- de keuze-intentie voor de technische vakrichting. 
Op elk van deze drie monitoring-indicatoren zal achtereenvolgens kort worden ingegaan.

Waarde-oriëntatie ten aanzien van techniek

De 'waarde-oriëntatie' ten aanzien van techniek geeft aan hoe jongeren staan tegenover technologische vooruitgang in het algemeen en bepaalde technologische ontwikkelingen in het bijzonder. Een eerste element van deze techniek-waarderingsschaal heeft betrekking op de interesse van jongeren voor techniek. Daarnaast wordt de houding van deze jongeren ten opzichte van de economische en maatschappelijke consequenties van technologische vernieuwing in beeld gebracht. Hierbij kan men bijvoorbeeld denken aan de verwachte gevolgen van de technologische ontwikkeling voor de werkloosheid en het milieu. Tenslotte zal worden nagegaan wat de houding van jongeren is ten opzichte van 'meisjes en techniek'.

\section{Beeldvorming ten aanzien van technisch onderwijs en technische beroepen}

Het relatieve imago van het technisch onderwijs is vanzelfsprekend ook een belangrijke maatstaf voor het maatschappelijk draagvlak voor technologische vernieuwingen. Bij dit imago wordt een onderscheid gemaakt tussen:

- de moeilijkheidsgraad van de opleiding;

- de arbeidsmarktpositie: werk en inkomen;

- $\quad$ enkele kwalitatieve aspecten van het werk.

Het beeld dat jongeren hebben van het technisch onderwijs wordt daarbij telkens gerelateerd aan hun percepties met betrekking tot andere - concurrerende - opleidingstypen. Bovendien wordt de beeldvorming op de hierboven genoemde aspecten zo mogelijk vergeleken met de beschikbare feitelijke informatie op deze punten.

\section{Keuze-intentie voor de technische richting}

De keuze-intentie van jongeren voor de technische richting zal in brede zin worden bekeken. In feite kan een onderscheid worden gemaakt tussen drie verschillende keuzemomenten. De eerste keuze betreft de keuze na het basisonderwijs voor een bepaald schooltype van het voortgezet onderwijs. Voor de jongeren in het algemeen voortgezet onderwijs (AVO) volgt enkele jaren later de keuze van het vakkenpakket, eventueel voorafgegaan door een keuze voor een bepaalde hoofdstroom. De derde keuze heeft tenslotte betrekking op de voorkeur voor een vervolgopleiding of de keuze voor een bepaald beroep. In dit onderzoek zal op alle drie genoemde keuzemomenten worden ingegaan, ofschoon de nadruk zal worden gelegd op de (uiteindelijke) vervolgkeuzes na het voortgezet onderwijs.

Voorts is het van belang mogelijke determinanten van de drie genoemde monitoring-indicatoren te achterhalen. Hierbij kan worden gedacht aan persoons- en omgevingskenmerken, maar ook aan de subjectieve inschatting door de jongeren van hun eigen capaciteiten. Het onderzoeksmodel kan dan schematisch worden weergegeven als in figuur 1.1. 
Figuur 1.1. Onderzoeksmodel

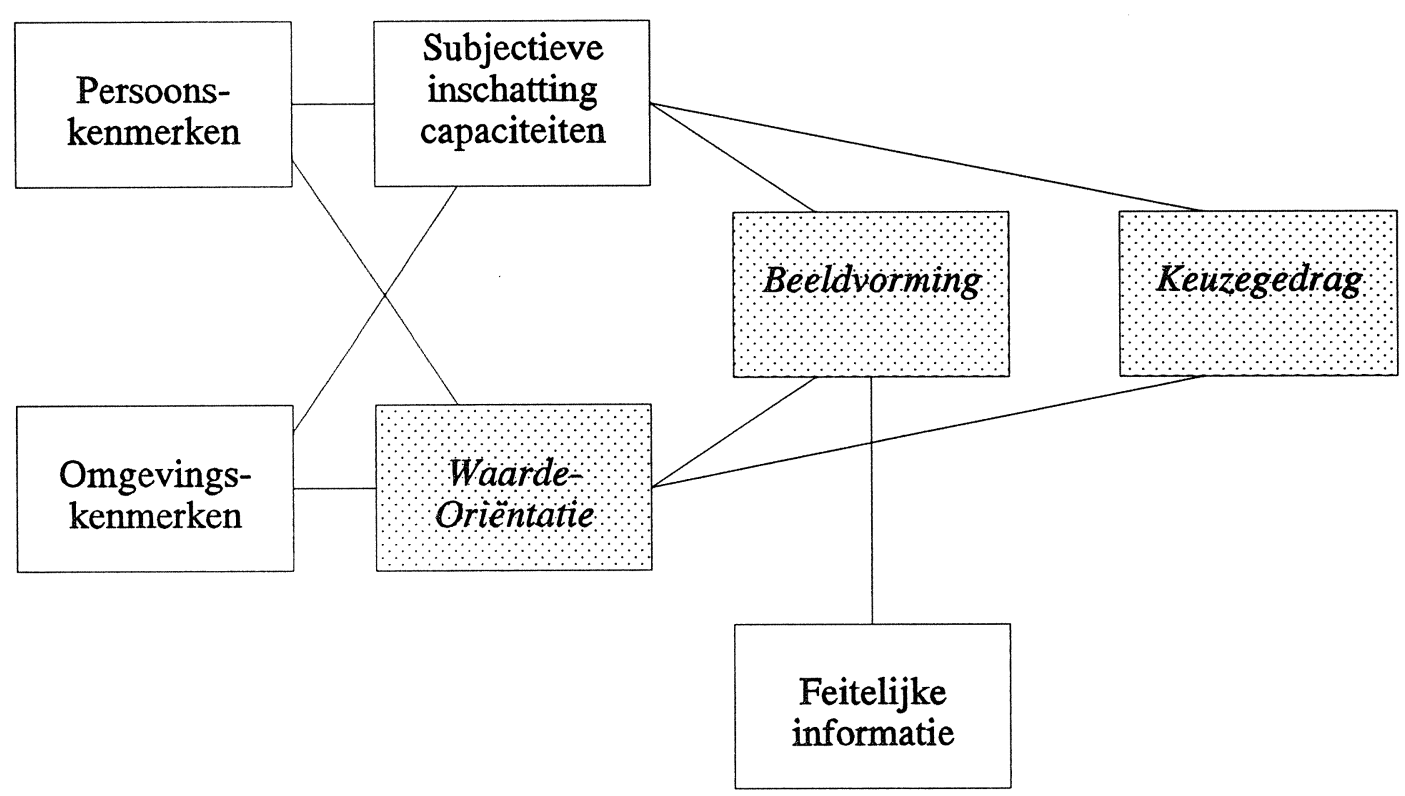

Naast het directe doel om de kernindicatoren - de publiekshouding van jongeren ten opzichte van techniek, het relatieve imago van het technisch onderwijs en het werkveld van technisch opgeleiden en het studiekeuzegedrag - te 'monitoren' en de relaties tussen deze indicatoren in kaart te brengen, zijn er ook enkele afgeleide doelstellingen van het onderzoek te noemen. In de eerste plaats zal worden getracht mogelijke knelpunten bij de keuze voor het technisch onderwijs of technische beroepen te traceren. Daarbij zal een verbijzondering worden gemaakt naar verscheidene opleidingsniveaus. Door het signaleren van dergelijke knelpunten wordt het wellicht mogelijk om meer specifieke doelgroepen te definiëren, waaruit (meer) belangstellenden voor het technisch onderwijs zouden kunnen worden geworven.

Om deze doelstellingen te kunnen realiseren, is in het najaar van 1992 een schriftelijke enquête gehouden onder ruim 2.000 leerlingen van het voortgezet onderwijs, verdeeld over de opleidingscategorieën Voorbereidend Beroepsonderwijs in de technische richting (VBOTechniek), Voorbereidend Beroepsonderwijs in de overige richtingen (VBO-Overig) ${ }^{1}$, Middelbaar Algemeen Voortgezet Onderwijs (MAVO) en Hoger Algemeen Voortgezet Onderwijs en Voorbereidend Wetenschappelijk Onderwijs (HAVO/VWO). Met deze vier opleidingscategorieën

1. Sinds 1 augustus 1992 is het VBO in de plaats gekomen van het Lager Beroepsonderwijs (LBO). 
zijn vrijwel alle opleidingen bestreken die rechtstreeks aansluiten op het basisonderwijs ${ }^{2}$, zodat landelijk representatieve uitspraken over de totale groep jongeren kunnen worden gedaan. De enquêtering heeft daarbij plaatsgevonden in het derde leerjaar van het VBO en het MAVO en het vierde leerjaar van het HAVO en $V_{W O}$. De gebruikte vragenlijst voor het $V W O$ is opgenomen in bijlage $A$ bij dit rapport ${ }^{4}$. Voor een beschrijving van de opzet van de enquête en de respons wordt verwezen naar hoofdstuk 2.

\subsection{Opzet van het rapport}

Het rapport is opgebouwd rondom de drie genoemde monitoring-indicatoren waarde-oriëntatie, beeldvorming en keuze-intentie. Deze komen respectievelijk aan de orde in de delen II, III en IV. Eerst wordt echter in hoofdstuk 2 van dit eerste deel nog ingegaan op de opzet van de enquête. Daarbij komen de steekproefopzet en de respons van zowel de scholen als de leerlingen aan bod. Daarna wordt kort ingegaan op de wijze van enquêtering. Voorts vindt in dit hoofdstuk een herweging van het databestand plaats, opdat landelijk representatieve uitspraken kunnen worden gedaan voor elk van de hierboven genoemde indicatoren.

In deel II van het rapport komt, zoals gezegd, de waardering onder jongeren voor techniek aan de orde. Hoofdstuk 3 besteedt daarbij aandacht aan de waarde-oriëntatie van leerlingen ten aanzien van techniek in het algemeen. Achtereenvolgens wordt ingegaan op de interesse voor techniek, de houding ten opzichte van de maatschappelijke en economische consequenties van techniek en de houding ten opzichte van de rol van meisjes in de techniek. Ook wordt de waardering voor techniek in zijn algemeenheid besproken. In hoofdstuk 4 wordt het bovengenoemde algemene beeld van techniek gedifferentieerd door in te gaan op enkele specifieke technologische ontwikkelingen. Tenslotte wordt in hoofdstuk 5 deel II kort samengevat.

Deel III van het rapport gaat vervolgens in op het imago van het technisch onderwijs. In hoofdstuk 6 wordt daarbij eerst aandacht besteed aan de gepercipieerde moeilijkheidsgraad van de technische (vervolg)opleidingen in relatie tot andere opleidingsrichtingen op een vergelijkbaar onderwijsniveau. Voorts komt in hoofdstuk 7 de arbeidsmarktpositie van de diverse opleidingsrichtingen aan de orde. Daarbij gaat het met name om het relatieve imago van de mogelijk te kiezen opleidingsrichtingen met betrekking tot de kans op werk en de kans op een hoog inkomen. Hoofdstuk 8 gaat daarna in op enkele kwalitatieve aspecten van het werkveld,

2. Enkele kleine opleidingstypen (bijvoorbeeld nautisch onderwijs), alsmede experimentele opleidingen zijn buiten beschouwing gebleven.

3. De argumentatie voor de keuze van de leerjaren is als volgt. Er is daarbij zoveel mogelijk voor gekozen de enquêtering te laten plaatsvinden rondom het keuzetijdstip van vakkenpakket of studierichting, zodat de gegeven antwoorden van de leerlingen op dit punt waarschijnlijk minder 'vrijblijvend' zijn.

4. De vragenlijsten voor VBO, MAVO en HAVO zijn op verzoek verkrijgbaar bij het secretariaat van het ROA. Overigens is vanwege de herkenbaarheid voor de leerlingen in de vragenlijsten nog de oude benaming LBO in plaats van VBO gehanteerd. 


$$
-7-
$$

zoals 'zwaar werk', 'stress', 'vuil werk' enz. In zowel hoofdstuk 7 als hoofdstuk 8 zal daarbij het gepercipieerde beeld worden vergeleken met meer feitelijke informatie over de desbetreffende kwantitatieve of kwalitatieve arbeidsmarktkenmerken. In hoofdstuk 9 wordt dit derde deel samengevat en zal worden getracht een totaalbeeld van het relatieve imago dat het technisch onderwijs onder jongeren heeft, te schetsen.

In deel IV gaat de aandacht uit naar de keuzes en keuze-intenties voor de technische richting. Hoofdstuk 10 beschrijft daarbij achtereenvolgens de keuze na het basisonderwijs en de vakkenpakketkeuze in het algemeen voortgezet onderwijs. In hoofdstuk 11 komt vervolgens de keuze na de huidige opleiding uitgebreid aan de orde. De centrale invalshoek in dit hoofdstuk zal de keuze-intentie voor de technische richting zijn. Hoofdstuk 12 vormt een samenvatting van dit vierde deel van het rapport.

Het rapport wordt in deel $V$ vervolgens afgesloten. Daarbij zullen eerst de voorgaande delen nogmaals globaal worden samengevat. Tenslotte zal worden ingegaan op de mogelijke beleidsimplicaties van de resultaten van dit onderzoek. Daarbij kan men denken aan het kwantificeren van mogelijke beleidsmaatregelen om het potentieel voor de technische richting te vergroten. Bovendien zullen in dit hoofdstuk specifieke doelgroepen gedefinieerd waarop potentiële campagnes om meer jongeren voor de technische richting te recruteren zich vooral zouden moeten richten. 


\section{OPZET VAN DE ENQUÊTE}

\subsection{Steekproeftrekking en respons}

In hoofdstuk 1 is reeds aangegeven dat het onderzoek betrekking heeft op de leerlingen van het voortgezet onderwijs, verdeeld over vier opleidingscategorieën. Om voor elk van deze vier categorieën - VBO-Techniek, VBO-Overig, MAVO en HAVO/VWO - representatieve uitspraken te kunnen doen, is gekozen voor een gestratificeerde steekproef. De beoogde omvang van deze steekproef bedroeg 80 deelnemende klassen in even zovele scholen, gelijk verdeeld over de vier opleidingscategorieën. Bovendien zou de steekproef zodanig moeten worden samengesteld dat de regionale spreiding overeenkomt met de werkelijke verhouding van de leerlingenaantallen.

De steekproeftrekking is gebaseerd op de gegevens van de Integrale Leerlingtelling (ILT) van het Ministerie van Onderwijs en Wetenschappen. Deze ILT is een registratie van het aantal leerlingen in het door dit Ministerie gefinancierd voortgezet onderwijs, verdeeld naar leerjaar. Daarbij gaat het om de cijfers per 15 september $1991^{5}$. Het lager agrarisch onderwijs, dat voor het merendeel wordt bekostigd door het Ministerie van Landbouw, Natuurbeheer en Visserij, is niet integraal in deze gegevens vertegenwoordigd. Op het te presenteren totaalbeeld - per opleidingscategorie - zal dit naar verwachting echter weinig invloed hebben.

Tabel 2.1. Aantal benaderde scholen en respons van de scholen per opleidingscategorie

\begin{tabular}{lccc}
\hline Opleidingscategorie & benaderd & \multicolumn{2}{c}{$\begin{array}{c}\text { positieve respons } \\
\text { abs. }\end{array}$} \\
& & & 50 \\
VBO-Techniek & 54 & 27 & 51 \\
VBO-Overig & 45 & 23 & 42 \\
W.v. VBO-Verzorgend & 24 & 10 & 55 \\
VBO-Economisch-Administratief & 11 & 6 & 70 \\
VBO-Agrarisch & 10 & 7 & 47 \\
MAVO & 51 & 24 & 45 \\
HAVO/VWO & & & 41 \\
W.v. HAVO & 47 & 21 & 50 \\
VWO & 27 & 11 & 48 \\
Totaal & 20 & 10 & 95 \\
\hline
\end{tabular}

In eerste instantie is op aselecte wijze een steekproef samengesteld van 153 scholen, rekening houdend met een gemiddelde negatieve en/of non-respons van circa 50\%. Deze scholen zijn in mei 1992 schriftelijk benaderd met het verzoek om deel te nemen aan de enquête. Aangezien

5. De resultaten van recentere tellingen zijn op dit moment nog niet beschikbaar. 
deze eerste steekproef voor enkele opleidingscategorieën in sommige regio's niet voldoende respons opleverde, is daarna nog een aantal scholen op aselecte wijze geselecteerd en vervolgens aangeschreven. Het totaal aantal benaderde scholen komt daarmee op 197. In tabel 2.1. is per opleidingstype aangegeven hoeveel scholen zijn benaderd en hoe groot de positieve respons (de bereidheid om in het onderzoek te participeren) is. Uit de tabel blijkt dat voor alle onderscheiden opleidingstypen het beoogd aantal scholen is bereikt. De totale positieve respons bedraagt 95 scholen, hetgeen overeenkomt met bijna $50 \%$. De regionale verdeling is goed te noemen, alhoewel de regio's west en zuid enigszins in de uiteindelijke steekproef zijn oververtegenwoordigd.

De schriftelijke enquête is telkens klassikaal gedurende één lesuur afgenomen in de periode oktober-november 1992. De afname heeft plaatsgevonden onder leiding van een door het ROA ingeschakelde testleider. De rol van deze testleider is daarbij zoveel mogelijk beperkt gebleven tot 'vraagbaak' voor de leerlingen. Vanuit de gedachte om de leerlingen de vragenlijst zoveel mogelijk met 'open mind' te laten invullen, hebben de testleiders geen uitgebreide inleiding gehouden over de doelstellingen van het onderzoek.

Tabel 2.2. geeft de samenstelling van de respons van de leerlingen, verdeeld naar opleidingscategorie en geslacht, weer. De totale respons bedraagt 2.315 leerlingen, overeenkomend met gemiddeld ongeveer 25 leerlingen per school. Het kleinste aantal deelnemende leerlingen in één school is 11 ; het grootste aantal respondenten van een school bedraagt $59^{6}$. In overeenstemming met het beeld van de respons bij de scholen, blijkt dat de vertegenwoordiging van $\mathrm{VBO}$-Techniek en MAVO-leerlingen verhoudingsgewijs iets hoger te zijn dan de deelname van de beide andere opleidingscategorieën.

Tabel 2.2. Samenstelling van de respons van de leerlingen naar opleidingscategorie en geslacht

\begin{tabular}{lccc}
\hline Opleidingscategorie & jongens & meisjes & totaal \\
\hline & $\%$ & $\%$ & $\%$ \\
VBO-Techniek & & 74 & 28 \\
VBO-Overig & 12 & 31 & 20 \\
MAVO & 27 & 32 & 29 \\
HAVO/VWO & 18 & 29 & 23 \\
Totaal & 1.285 & 1.021 & 2.315 \\
\hline
\end{tabular}

\subsection{Herweging van het databestand}

Zoals reeds werd opgemerkt, is gebruik gemaakt van een gestratificeerde steekproef. Om de resultaten op landelijk niveau representatief te laten zijn voor de totale groep jongeren van 14 à

6. Bij sommige scholen zijn meerdere klassen geënquêteerd om een evenredige verdeling van het aantal leerlingen van de diverse richtingen te verkrijgen. 
15 jaar, moet het databestand derhalve worden herwogen. Deze herweging vindt plaats aan de hand van de gegevens van de ILT, aangevuld met gegevens over het aantal leerlingen in het lager agrarisch onderwijs, welke afkomstig zijn van het Ministerie van Landbouw, Natuurbeheer en Visserij (1992). Als wegingsvariabelen zijn opleiding (verdeeld over de zeven onderscheiden opleidingstypen) en regio (uitgesplitst over de vier windstreken) genomen. In tabel 2.3. is op basis van het herwogen bestand voor de vier onderscheiden opleidingscategorieën de regionale spreiding weergegeven.

Tabel 2.3. Herwogen databestand naar opleidingscategorie en regio

\begin{tabular}{lcccc}
\hline Opleidingscategorie & noord & oost & west & zuid \\
\hline & $\%$ & $\%$ & $\%$ & 14 \\
VBO-Techniek & 17 & 15 & 14 & 16 \\
VBO-Overig & 10 & 20 & 16 & 29 \\
MAVO & 34 & 30 & 41 & 40 \\
HAVO/VWO & 39 & 36 & 989 & 579 \\
N & 243 & 504 & & \\
\hline
\end{tabular}

Aangezien de leerlinggegevens van het Ministerie van Landbouw, Natuurbeheer en Visserij niet geslachtsspecifiek zijn, is het niet mogelijk het databestand ook te herwegen naar geslacht. Wel kan op basis van het (naar opleiding en regio) herwogen bestand per opleidingscategorie de verdeling naar geslacht worden weergegeven (zie tabel 2.4.). Het blijkt dat - na herweging jongens en meisjes ongeveer gelijk in het databestand zijn vertegenwoordigd. Dit zal in grote lijnen in overeenstemming zijn met het landelijke beeld.

Tabel 2.4. Herwogen databestand naar opleidingscategorie en geslacht

\begin{tabular}{lccc}
\hline Opleidingscategorie & jongens & meisjes & totaal \\
\hline & $\%$ & $\%$ & $\%$ \\
VBO-Techniek & 26 & 3 & 15 \\
VBO-Overig & 9 & 24 & 16 \\
MAVO & 30 & 29 & 30 \\
HAVO/VWO & 35 & 44 & 39 \\
N & 1.134 & 1.176 & 2.315 \\
\hline
\end{tabular}

In het vervolg van dit rapport zal in de tabellen telkens het gewogen aantal waarnemingen (N) worden gepresenteerd. De statistische toetsen zullen zijn gebaseerd op een gedeeltelijk gewogen databestand (in principe alleen naar regio, maar voor VBO-Overig en HAVO/VWO ook over de onderliggende opleidingsrichtingen). De multivariate analyses zullen worden uitgevoerd 
$-11-$

met behulp van het ongewogen bestand. In deze tabellen wordt dan ook het ongewogen aantal waarnemingen $(n)$ gepresenteerd. 

DEEL II

WAARDERING VOOR TECHNIEK 



\section{WAARDERING: INTERESSE EN HOUDING}

\subsection{Informatie over techniek}

In dit tweede deel van het rapport zal worden ingegaan op de waardering onder jongeren voor techniek. Daarbij gaat het niet alleen om de interesse voor techniek en de houding van jongeren ten aanzien van eventuele economische of maatschappelijke gevolgen van technologische vernieuwing, maar ook om de houding van de leerlingen ten opzichte van meisjes in de technische sector.

Alvorens daar nader op in te gaan, zal eerst in deze paragraaf kort aandacht worden besteed aan de informatiebronnen van jongeren over techniek. Tabel 3.1. geeft aan wat voor de leerlingen de belangrijkste informatiebronnen over techniek zijn. Zoals bij vrijwel alle tabellen in dit rapport het geval zal zijn, wordt daarbij een uitsplitsing gegeven naar de vier onderscheiden opleidingscategorieën en naar geslacht. Door de VBO-leerlingen worden de docenten het vaakst genoemd als informatiebron. Opvallend is echter dat niet alle VBO-Techniek-leerlingen hun docenten beschouwen als belangrijk doorgeefluik van informatie over techniek. Klaarblijkelijk associëren deze leerlingen hun onderwijs niet altijd met techniek. Voor AVO-leerlingen blijken de kranten, radio of televisie de belangrijkste informatiebronnen te zijn. De docenten vormen voor deze leerlingen ook een belangrijke bron van informatie.

Tabel 3.1. Informatiebronnen over techniek naar opleidingscategorie en geslacht

\begin{tabular}{|c|c|c|c|c|c|c|c|c|}
\hline \multirow[t]{2}{*}{ Informatiebronnen } & \multicolumn{2}{|c|}{ VBO-Techniek } & \multicolumn{2}{|c|}{ VBO-Overig } & \multicolumn{2}{|c|}{ MAVO } & \multicolumn{2}{|c|}{ HAVO/VWO } \\
\hline & $\mathrm{j}$ & $\mathrm{m}$ & $\mathrm{j}$ & m & $\mathrm{j}$ & $\mathrm{m}$ & j & $\mathrm{m}$ \\
\hline & $\%$ & $\%$ & $\%$ & $\%$ & $\%$ & $\%$ & $\%$ & $\%$ \\
\hline docenten & 70 & 64 & 63 & 84 & 59 & 63 & 62 & 67 \\
\hline ouders/verzorgers & 50 & 45 & 54 & 43 & 51 & 41 & 52 & 45 \\
\hline vrienden/vriendinnen & 29 & 28 & 28 & 17 & 32 & 14 & 36 & 14 \\
\hline folders of kennismakingsdagen van & & & & & & & & \\
\hline scholen of bedrijven & 58 & 59 & 42 & 44 & 43 & 39 & 48 & 37 \\
\hline kranten, radio of televisie & 50 & 52 & 56 & 49 & 62 & 65 & 83 & 77 \\
\hline tijdschrift over techniek & 33 & 24 & 32 & 19 & 40 & 11 & 47 & 15 \\
\hline hobbyclub over techniek & 8 & 4 & 10 & 3 & 7 & 2 & 3 & 4 \\
\hline museum & 12 & 12 & 10 & 10 & 21 & 15 & 22 & 20 \\
\hline andere manier & 10 & 6 & 14 & 6 & 15 & 11 & 10 & 6 \\
\hline $\mathrm{N}$ & 292 & 38 & 96 & 275 & 337 & 338 & 396 & 503 \\
\hline
\end{tabular}

Uit de tabel blijkt verder dat de leerlingen van alle onderscheiden opleidingscategorieën de ouders zien als een belangrijke informatiebron op het punt van techniek: ongeveer de helft van de leerlingen heeft dit aangegeven. Ook folders of kennismakingsdagen van scholen of bedrijven gelden als belangrijk middel van informatie. Daarentegen blijken musea en vooral hobbyclubs 
relatief weinig te worden gebruikt als informatiebron. Een opvallend verschil tussen jongens en meisjes doet zich voor ten aanzien van de informatie van vrienden/vriendinnen en ten aanzien van technische tijdschriften. Jongens blijken op deze beide manieren vaker informatie over techniek te krijgen.

\subsection{Waarderingsschalen met betrekking tot techniek}

Voor alle drie de elementen van de waardering voor techniek ('interesse', 'consequenties van techniek' en 'meisjes en techniek') wordt nauw aangesloten bij het technologie-meetinstrument dat is ontwikkeld door De Klerk Wolters (1989). Dit instrument beoogt de attitude van jongens en meisjes ten aanzien van techniek te kwantificeren. De Klerk Wolters maakt daarbij een onderscheid tussen enerzijds schalen die de affectieve en conatieve aspecten van de attitude ten aanzien van techniek meten en anderzijds schalen die de cognitieve aspecten van deze attitude meten. Hij spreekt in dit verband van respectievelijk $A B$-schalen (Attitude-Behaviour) en $C$-schalen (Cognitive)'. Het onderzoek resulteert vervolgens in vier gemeenschappelijke attitude-dimensies: behalve de drie hiervoor reeds genoemde elementen interesse, consequenties en rolpatronen is dat de moeilijkheid van techniek. Op dit laatste aspect wordt in deel III van dit rapport teruggekomen.

Uitgaande van de vier attitude-instrumenten zijn er door De Klerk Wolters zes AB-schalen geconstrueerd. De dimensie interesse is daarbij opgesplitst in drie onderdelen, te weten 'techniek in het algemeen', 'techniek op school' en 'techniek als beroep'. Elk van de schalen bestaat daarbij uit een aantal beweringen ('items'), waarvan de leerlingen moeten aangegeven of zij het daarmee 'helemaal eens', 'eens', 'niet eens, niet oneens', 'oneens' of 'helemaal oneens' zijn'. Door middel van factoranalyse is door De Klerk Wolters nagegaan of de gebruikte schalen valide zijn. Daarnaast is getoetst of de schalen betrouwbaar en intern consistent zijn. Alle toetsen hadden daarbij een gunstig resultaat.

Door ons is vervolgens een aantal items - verdeeld over de drie elementen - van dit technologiemeetinstrument geselecteerd om de waardering ten aanzien van techniek te kunnen meten. Aangezien de (uitgebreide) schalen reeds zijn gevalideerd, is ervan uitgegaan dat de beperkte schalen eveneens valide zijn. Wel is de betrouwbaarheid van of deze qua hoeveelheid items beperkte schalen nagegaan. Het blijkt dat ook de beperkte schalen als voldoende betrouwbaar kunnen worden getypeerd. Voor een verdere toelichting en de resultaten van de betrouwbaarheidsanalyses wordt verwezen naar bijlage B.

1. Daarnaast wordt door De Klerk Wolters een verkorte versie van dit meetinstrument beschreven. Deze korte vragenlijst, genaamd Technology Attitude Scale (TAS), is primair ontwikkeld om techniekdocenten op een eenvoudige manier in de eigen klas de attitude ten aanzien van techniek te kunnen laten meten.

2. Men spreekt in dit verband van een Likertschaal-model (zie bijvoorbeeld Mueller, 1986). 


\subsection{Interesse voor techniek}

Bij de 'interesse'-schaal is door ons - in tegenstelling tot De Klerk Wolters - geen onderscheid gemaakt tussen drie vormen van interesse in techniek, maar is alleen het onderdeel techniek in het algemeen opgenomen. Daarbij zijn zes items geselecteerd. Een uiterst negatieve attitude ten aanzien van techniek op een bepaald item is gewaardeerd met 1 punt, terwijl een uiterst positieve houding 5 punten oplevert. In tabel 3.2. is per geslacht de gemiddelde score op de onderscheiden items weergegeven. Dit betekent dat een gemiddelde itemscore van hoger dan 3 per saldo een positieve attitude ten opzichte van techniek aangeeft en een score van lager dan 3 een negatieve attitude.

Tabel 3.2. Interesse voor techniek naar geslacht ${ }^{\mathrm{a}}$

Item jongens meisjes

Techniek interesseert me niet Ik lees niet graag technische tijdschriften

Als er een hobbyclub over techniek was, werd ik zeker lid

Er zouden meer televisieprogramma's over techniek moeten zijn

$\mathrm{Ik}$ vind het leuk om thuis zelf iets te repareren

Als er iets nieuws is uitgevonden, wil ik er graag meer van weten
$3,76 \quad 2,40$

$2,94 \quad 1,86$

$2,42 \quad 1,64$

$3,11 \quad 2,31$

$3,80 \quad 2,80$

$3,85 \quad 2,93$

a score groter dan 3 drukt positieve attitude uit

Het meest in het oog springend bij deze tabel is dat bij alle items blijkt dat jongens meer in techniek zijn geïnteresseerd dan meisjes. Bij de eerste bewering, die vrij direct naar de interesse in techniek vraagt, blijkt bij jongens een betrekkelijk hoge interesse (gemiddelde waarde van 3,76). De meisjes blijven daar sterk bij achter met een gemiddelde score die duidelijk beneden het schaalmidden van 3 blijft. Uit de achterliggende cijfers ${ }^{3}$ blijkt dat meer dan $50 \%$ van de meisjes het met de bewering 'Techniek interesseert me niet' (helemaal) eens is. Bij de jongens bedraagt dit percentage circa $20 \%$, terwijl $60 \%$ van de jongens het met deze stelling (helemaal) oneens is.

Voor zowel jongens als meisjes geldt dat van de in de enquête opgenomen elementen het zelf iets repareren en nieuwe uitvindingen tot de meest interessante aspecten van techniek worden gerekend. Ruim $65 \%$ van de jongens vindt het leuk om zelf iets te repareren. Bij de meisjes zegt echter slechts $30 \%$ dit leuk te vinden, terwijl ongeveer $40 \%$ reparatieklusjes niet interessant vindt. Bij de belangstelling voor nieuwe uitvindingen wordt een soortgelijk beeld waargenomen. Hieruit zou men kunnen afleiden dat jongens een redelijk grote interesse in techniek hebben. Dit leidt er echter niet toe dat men een technisch tijdschrift zou willen lezen of dat men lid zou worden van een technische hobbyclub. Jongens staan bovendien vrij indifferent tegenover TVprogramma's over techniek. Bij meisjes zijn technische tijdschriften, hobbyclubs over techniek

3. Vanwege de grote hoeveelheid gegevens zijn deze niet in tabelvorm in dit rapport opgenomen. 
en TV-programma's over techniek in het geheel niet populair.

In figuur 3.1. is per opleidingscategorie en geslacht aangegeven wat de gemiddelde score op de interesseschaal is. Met behulp van de stippellijn is daarbij het schaalmidden weergegeven. Vanzelfsprekend is ook in deze figuur goed zichtbaar dat de interesse voor techniek bij meisjes duidelijk kleiner is dan bij jongens. Dit verschil blijkt zich bij alle opleidingscategorieën voor te doen. Bovendien geldt voor alle opleidingscategorieën dat de interesse van meisjes voor techniek beneden het schaalmidden is. Jongens zijn daarentegen bij alle opleidingscategorieën wel redelijk in techniek geïnteresseerd.

Figuur 3.1. Interesse voor techniek naar opleidingscategorie en geslacht ${ }^{\mathrm{a}}$

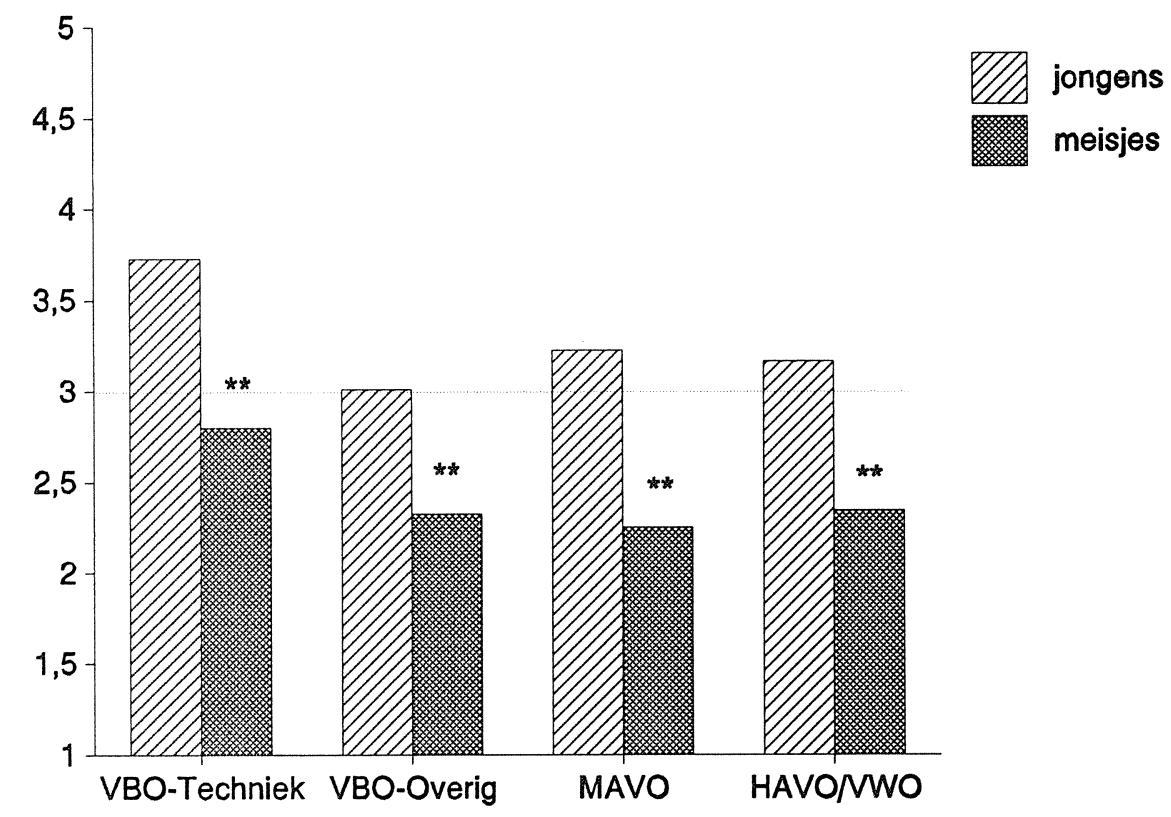

* = significant $5 \%$-niveau; ${ }^{*}=$ significant $1 \%$-niveau

a score groter dan 3 drukt positieve attitude uit

Zoals mocht worden verwacht, is de interesse bij VBO-Techniek-leerlingen significant hoger dan bij alle andere opleidingscategorieën. Opvallend is echter dat de meisjes van deze opleidingscategorie niet zo in techniek zijn geïnteresseerd. Weliswaar heeft deze groep gemiddeld duidelijk meer interesse voor techniek dan de andere meisjes van het voortgezet onderwijs, maar ook voor hen is de score op de interesseschaal beneden het schaalmidden. Waarschijnlijk hangt dit interessepatroon echter samen met het feit dat de meisjes van het VBOTechniek relatief vaker kiezen voor richtingen als consumptieve techniek ${ }^{4}$. Overigens moet

4. De enquête verschaft over de richtingkeuze binnen de onderscheiden VBO-sectoren geen informatie. 
hierbij worden opgemerkt dat er slechts weinig vrouwelijke VBO-Techniek-leerlingen in de enquête zijn opgenomen.

Verder is het opmerkelijk dat de interesse voor techniek bij VBO-Overig-leerlingen en dan vooral bij de jongens op deze opleiding vrij hoog is. Dit zou erop kunnen duiden dat al op jonge leeftijd een omvangrijke groep jongeren voor de technische richting 'verloren' lijkt te gaan, terwijl deze groep in potentie toch een redelijke interesse voor techniek heeft. Hierbij moet wel worden opgemerkt dat ook binnen het $\mathrm{VBO}-$ Overig - en dan vooral bij het agrarisch onderwijs - enkele opleidingsrichtingen bestaan die technisch zijn georiënteerd.

Tussen de beide onderscheiden AVO-opleidingstypen bestaat er slechts weinig verschil in de interesse voor techniek. De jongens van beide opleidingscategorieën hebben een redelijke interesse voor de techniek. Zoals voor alle opleidingscategorieën is de interesse onder meisjes echter veel lager.

Tot nu toe is slechts aandacht besteed aan de interesse voor techniek, waarbij een onderscheid is gemaakt tussen opleidingscategorie en geslacht. In het in hoofdstuk 1 beschreven onderzoeksmodel is echter reeds aangegeven dat er meer factoren (persoons- en omgevingskenmerken) van invloed zouden kunnen zijn op de waarde-oriëntatie ten aanzien van techniek. Om na te gaan welke factoren significant gerelateerd zijn aan de interesse van de leerlingen in techniek, is per opleidingscategorie een multivariate analyse uitgevoerd. Daarbij zijn de volgende (groepen) variabelen in de modellen opgenomen:

- geslacht;

- etniciteit;

- rapportcijfers;

- regio;

- $\quad$ typering van de leerling

- $\quad$ opleidingsniveau van de ouders ${ }^{6}$;

- beroepsrichting van de ouders.

De resultaten van de analyse zijn weergegeven in tabel 3.3. In bijlage $\mathrm{C}$ wordt een nadere toelichting gegeven op de gebruikte variabelen bij de in dit rapport gepresenteerde multivariate analyses.

5. Deze typering vindt plaats aan de hand van hetgeen de leerlingen het belangrijkste vinden voor hun eigen toekomst. De leerlingen die 'met mensen omgaan' het belangrijkste vinden zou men kunnen beschouwen als de meer sociaal-gerichte leerlingen. Degenen die respectievelijk 'carrière maken' en 'nuttig werk doen' het belangrijkste vinden zou men respectievelijk kunnen typeren als min of meer materialistisch- en idealistisch-georiënteerd.

6. Wanneer in dit rapport wordt gesproken van respectievelijk ouders, vader of moeder, wordt telkens bedoeld ouders/verzorgers, vader/verzorger en moeder/verzorgster. 
Tabel 3.3. Schattingsresultaten van een multivariate analyse van de interesse voor techniek naar opleidingscategorie (standaardfouten tussen haakjes)

\begin{tabular}{|c|c|c|c|c|c|c|c|c|}
\hline \multirow{2}{*}{$\begin{array}{l}\begin{array}{l}\text { Onafhankelijke } \\
\text { variabele }\end{array} \\
\text { constante }\end{array}$} & \multicolumn{2}{|c|}{ VBO-Techniek } & \multicolumn{2}{|c|}{ VBO-Overig } & \multicolumn{2}{|c|}{ MAVO } & \multicolumn{2}{|c|}{ HAVO/VWO } \\
\hline & $3,68^{* \prime}$ & $(0,15)$ & $3,14^{* *}$ & $(0,20)$ & $2,66^{* *}$ & $(0,54)$ & $2,96^{* *}$ & $(0,53)$ \\
\hline geslacht & $-0,96^{*}$ & $(0,11)$ & $-0,68^{* \prime}$ & $(0,10)$ & $-0,91^{* *}$ & $(0,10)$ & $-0,74^{* *}$ & $(0,09)$ \\
\hline etniciteit & 0,19 & $(0,11)$ & 0,09 & $(0,13)$ & 0,17 & $(0,19)$ & 0,20 & $(0,19)$ \\
\hline rapportcijfers A-vakken & n.v.t. & & n.v.t. & & $-0,08$ & $(0,08)$ & $-0,20 *$ & $(0,07)$ \\
\hline rapportcijfers B-vakken & n.v.t. & & n.v.t. & & $0,20^{* *}$ & $(0,06)$ & $0,28^{* *}$ & $(0,05)$ \\
\hline \multicolumn{9}{|l|}{ Regio } \\
\hline noord & 0,17 & $(0,11)$ & 0,01 & $(0,17)$ & $-0,30$ & $(0,21)$ & $-0,04$ & $(0,13)$ \\
\hline oost & 0,13 & $(0,11)$ & $0,34^{*}$ & $(0,12)$ & $-0,16$ & $(0,14)$ & 0,17 & $(0,13)$ \\
\hline west & \multicolumn{2}{|c|}{ referentie } & \multicolumn{2}{|c|}{ referentie } & \multicolumn{2}{|c|}{ referentie } & \multicolumn{2}{|c|}{ referentie } \\
\hline zuid & 0,11 & $(0,08)$ & 0,15 & $(0,10)$ & $-0,01$ & $(0,11)$ & 0,17 & $(0,11)$ \\
\hline \multicolumn{6}{|l|}{ Typering van de leerling } & $(0,13)$ & $-0,19$ & $(0,11)$ \\
\hline $\begin{array}{l}\text { met mensen omgaan } \\
\text { carrière maken }\end{array}$ & $\begin{array}{l}-0,23^{\circ} \\
-0,17^{\prime}\end{array}$ & $\begin{array}{l}(0,09) \\
(0,07)\end{array}$ & 0,07 & $(0,11)$ & 0,07 & $(0,13)$ & $-0,08$ & $(0,12)$ \\
\hline nuttig werk doen & \multicolumn{2}{|c|}{ referentie } & \multicolumn{2}{|c|}{ referentie } & \multicolumn{2}{|c|}{ referentie } & \multicolumn{2}{|c|}{ referentie } \\
\hline \multicolumn{9}{|l|}{ Opleidingsniveau vader } \\
\hline Algemeen onderwijs & \multicolumn{2}{|c|}{ referentie } & \multicolumn{2}{|c|}{ referentie } & \multicolumn{2}{|c|}{ referentie } & \multicolumn{2}{|c|}{ referentie } \\
\hline Lager beroepsonderwijs & 0,13 & $(0,08)$ & 0,21 & $(0,12)$ & $-0,03$ & $(0,15)$ & $-0,14$ & $(0,14)$ \\
\hline Middelbaar beroepsonderwijs & 0,19 & $(0,14)$ & 0,32 & $(0,20)$ & 0,20 & $(0,20)$ & $-0,18$ & $(0,18)$ \\
\hline Hoger onderwijs & 0,25 & $(0,15)$ & 0,18 & $(0,24)$ & 0,13 & $(0,18)$ & 0,02 & $(0,12)$ \\
\hline anders/weet niet & 0,11 & $(0,10)$ & 0,01 & $(0,14)$ & 0,12 & $(0,14)$ & $-0,11$ & $(0,15)$ \\
\hline \multicolumn{9}{|l|}{ Opleidingsniveau moeder } \\
\hline Algemeen onderwijs & \multicolumn{2}{|c|}{ referentie } & \multicolumn{2}{|c|}{ referentie } & \multicolumn{2}{|c|}{ referentie } & \multicolumn{2}{|c|}{ referentie } \\
\hline Lager beroepsonderwijs & 0,09 & $(0,09)$ & $-0,09$ & $(0,12)$ & 0,03 & $(0,12)$ & 0,15 & $(0,13)$ \\
\hline Middelbaar beroepsonderwijs & 0,22 & $(0,18)$ & $-0,04$ & $(0,21)$ & 0,17 & $(0,17)$ & 0,12 & $(0,16)$ \\
\hline Hoger onderwijs & 0,20 & $(0,32)$ & 0,14 & $(0,36)$ & $-0,29$ & $(0,34)$ & 0,05 & $(0,14)$ \\
\hline anders/weet niet & 0,03 & $(0,10)$ & 0,07 & $(0,15)$ & $-0,18$ & $(0,15)$ & $-0,08$ & $(0,17)$ \\
\hline Beroepsrichting vader & & & & & & & & \\
\hline $\begin{array}{l}\text { technisch } \\
\text { economisch }\end{array}$ & $\begin{array}{l}0,20^{\circ} \\
0,22^{\circ}\end{array}$ & $\begin{array}{l}(0,08) \\
(0,11)\end{array}$ & $\begin{array}{l}0,09 \\
0,01\end{array}$ & $\begin{array}{l}(0,10) \\
(0,12)\end{array}$ & $\begin{array}{l}-0,14 \\
-0,24\end{array}$ & $\begin{array}{l}(0,13) \\
(0,14)\end{array}$ & $\begin{array}{r}0,17 \\
-0,07\end{array}$ & $\begin{array}{l}(0,12) \\
(0,12)\end{array}$ \\
\hline $\begin{array}{l}\text { economisch } \\
\text { medisch/dienstverl./ }\end{array}$ & & & & & & & & \\
\hline verzorgend & 0,02 & $(0,14)$ & $-0,22$ & $(0,17)$ & $-0,27$ & $(0,20)$ & $-0,05$ & $(0,16)$ \\
\hline overig & refere & & refere & & refere & & refere & ntie \\
\hline weet niet & 0,29 & $(0,16)$ & 0,16 & $(0,19)$ & $-0,29$ & $(0,27)$ & $-0,31$ & $(0,29)$ \\
\hline Beroepsrichting moeder & & & & & & & & \\
\hline technisch & $-0,30$ & $(0,22)$ & $-0,12$ & $(0,27)$ & 0,42 & $(0,34)$ & 0,11 & $(0,40)$ \\
\hline economisch & $-0,23$ & $(0,13)$ & $-0,39^{*}$ & $(0,17)$ & $-0,13$ & $(0,20)$ & $-0,34^{* *}$ & $(0,13)$ \\
\hline $\begin{array}{l}\text { medisch/dienstverl./ } \\
\text { verzorgend }\end{array}$ & $-0,30^{*}$ & $(0,12)$ & $-0,37^{*}$ & $(0,14)$ & 0,04 & $(0,20)$ & $-0,34^{* *}$ & $(0,13)$ \\
\hline overig & refere & & refere & tie & refere & tie & refere & ntie \\
\hline $\begin{array}{l}\text { nooit beroep gehad/ } \\
\text { weet niet }\end{array}$ & $-0,23$ & $(0,12)$ & $-0,18$ & $(0,15)$ & 0,06 & $(0,21)$ & $-0,34^{*}$ & $(0,17)$ \\
\hline $\mathrm{n}$ & 755 & & 363 & & 330 & & 329 & \\
\hline $\mathrm{R}^{2}$ & 0,24 & & 0,30 & & 0,37 & & 0,38 & \\
\hline
\end{tabular}


Ook uit deze analyses blijkt dat het geslacht de belangrijkste factor is ten aanzien van de interesse in techniek. Rekening houdend met de overige in het model opgenomen factoren, kan worden vastgesteld dat meisjes variërend van 0,67 tot 0,96 lager scoren op de 5-puntsinteresseschaal dan jongens. Voor de beide onderscheiden AVO-opleidingscategorieën blijkt dat de interesse voor techniek ook sterk samenhangt met de rapportcijfers. HAVO/VWO-leerlingen met hoger cijfers voor de A-vakken zijn doorgaans minder geïnteresseerd in de technische richting, terwijl de leerlingen van beide AVO-opleidingscategorieën die hoog scoren voor Bvakken meer in techniek geïnteresseerd zijn. Voor leerlingen die in beide richtingen hoog, dan wel laag scoren, geldt per saldo dat zij meer in techniek zijn geïnteresseerd dan de leerlingen die alleen voor A-vakken hoge cijfers of alleen voor de B-vakken lage cijfers hebben. Voor het VBOOverig wordt een regio-effect waargenomen. Het blijkt dat de leerlingen in het oosten van het land meer in techniek zijn geïnteresseerd. Mogelijkerwijs hangt dit effect samen met de verschillen in de werkgelegenheidsstructuur tussen de regio's. Verder blijkt uit de tabel dat de VBO-Techniek-leerlingen die hebben aangegeven dat 'met mensen omgaan' of 'carrière maken' het belangrijkste is voor hun eigen toekomst significant minder in techniek zijn geïnteresseerd dan degenen die 'nuttig werk doen' het belangrijkste vinden.

Het opleidingsniveau van de ouders blijkt voor alle opleidingscategorieën niet van invloed te zijn op de interesse voor techniek. Daarentegen bestaat er wel een significant verband tussen de interesse en de beroepsrichting van de ouders. VBO-Techniek-leerlingen, waarvan de vader een technisch beroep heeft, blijken significant meer in techniek te zijn geïnteresseerd. Hier is derhalve sprake van een duidelijk vader/kind-effect. Ook de VBO-Techniek-leerlingen waarvan de vader een economisch beroep uitoefent blijken meer in techniek te zijn geïnteresseerd. Verder is het opvallend dat de leerlingen met een moeder, die in de medische/dienstverlenende sfeer werkzaam is (geweest) significant minder interesse in de technische richting blijken te hebben. Ook voor VBO-Overig-leerlingen is dit het geval, terwijl voor deze groep bovendien geldt dat degenen waarvan de moeder in de economische richting werkzaam is of was, minder technische interesse blijken te vertonen. Bij het HAVO/VWO wordt verder geconstateerd dat de leerlingen, waarvan de moeder in een economisch beroep of een beroep in de medische sfeer werkzaam is, minder in de techniek zijn geïnteresseerd.

\subsection{Consequenties van techniek}

Het tweede onderdeel van de techniek-waarderingsschaal betreft de houding van jongeren ten opzichte van de maatschappelijke en economische consequenties van techniek. In de vragenlijst zijn voor deze schaal tien verschillende items opgenomen. Daarbij gaat het om zowel meer economisch-gerichte items als meer sociaal-gerichte items. In tabel 3.4. zijn de items met hun gemiddelde schaalscore voor jongens en meisjes weergegeven.

Evenals bij de items met betrekking tot de interesse voor techniek, blijkt dat ook bij de beweringen ten aanzien van de maatschappelijke en economische consequenties van techniek jongens op alle onderdelen een positiever beeld hebben dan meisjes. De verschillen zijn echter minder pregnant dan bij de interesseschaal. In het algemeen kan worden opgemerkt dat zeker bij 
jongens een vrij positief beeld bestaat van de mogelijke gevolgen van technologische vernieuwingen. Ook meisjes scoren op de meeste items echter per saldo boven het schaalmidden.

Tabel 3.4. Houding ten opzichte van de consequenties van technologische ontwikkelingen naar geslacht $^{3}$

Item

jongens meisjes

Techniek is goed voor de toekomst van ons land

$4,05 \quad 3,64$

Techniek is niet belangrijk in het leven

4,10

3,83

Door techniek wordt het leven ingewikkelder

3,17

3,13

Omdat techniek vervuiling veroorzaakt, moeten we het minder gebruiken

3,46

2,93

Door techniek gaat alles beter

3,48

3,14

Techniek veroorzaakt een hoge werkloosheid

3,50

3,37

Techniek heeft meer goede dingen dan slechte dingen gebracht

3,58

3,19

Techniek is goed voor de economie van ons land

3,81

3,49

De wereld zou er beter uitzien zonder techniek

3,92

3,70

Ik vind dat we de wereld te snel laten veranderen door de techniek

3,10

2,90

${ }^{a}$ score groter dan 3 drukt positieve attitude uit

Wanneer wat dieper op de afzonderlijke items wordt ingegaan, dan blijkt dat vooral de economische gevolgen van de technologische ontwikkeling door de leerlingen vrij positief worden ingeschat. De per saldo iets negatievere waardering van meisjes op deze onderdelen hangt daarbij samen met het feit dat zij vaker een neutraal standpunt innemen, terwijl jongens daarentegen een meer uitgesproken mening etaleren. De vrij direct gestelde bewering 'Techniek is goed voor de economie van ons land' wordt door $65 \%$ van de jongens instemmend beantwoord, tegenover bijna $50 \%$ van de meisjes. De leerlingen hebben in het algemeen een iets minder positief beeld van de meer sociale consequenties van techniek. Op de stelling 'Ik vind dat we de wereld te snel laten veranderen door de techniek' wordt gemiddeld genomen zowel door jongens als door meisjes neutraal gereageerd. Het mogelijke milieuvervuilende aspect van technologische vernieuwing wordt door jongens en meisjes wel verschillend beoordeeld. Terwijl circa $50 \%$ van de jongens van mening is dat we op grond van de vervuilingsproblematiek niet minder van techniek gebruik hoeven te maken, is slechts $25 \%$ van de meisjes het met deze mening eens.

In figuur 3.2. wordt de houding ten opzichte van de economische en maatschappelijke consequenties van techniek nogmaals grafisch weergegeven, verdeeld naar opleidingscategorie en geslacht. De redelijk positieve waardering van techniek op dit punt, zoals reeds geconstateerd in tabel 3.4., blijkt zich voor te doen bij alle vier onderscheiden opleidingscategorieën. Ook blijkt voor alle vier categorieën dat meisjes een minder positief beeld hebben van de maatschappelijke consequenties van techniek dan jongens.

Uit de figuur blijkt bovendien dat tussen de vier opleidingscategorieën op dit punt niet zoveel verschillen bestaan. Wel kan worden geconstateerd dat de VBO-Techniek-leerlingen iets positiever staan tegenover de consequenties van technologische ontwikkelingen dan de 
leerlingen van de overige opleidingen. De VBO-Overig-leerlingen schatten de mogelijke gevolgen van technologische vernieuwing iets minder positief in.

Figuur 3.2. Houding ten opzichte van de consequenties van technologische ontwikkelingen naar opleidingscategorie en geslacht ${ }^{\mathrm{a}}$

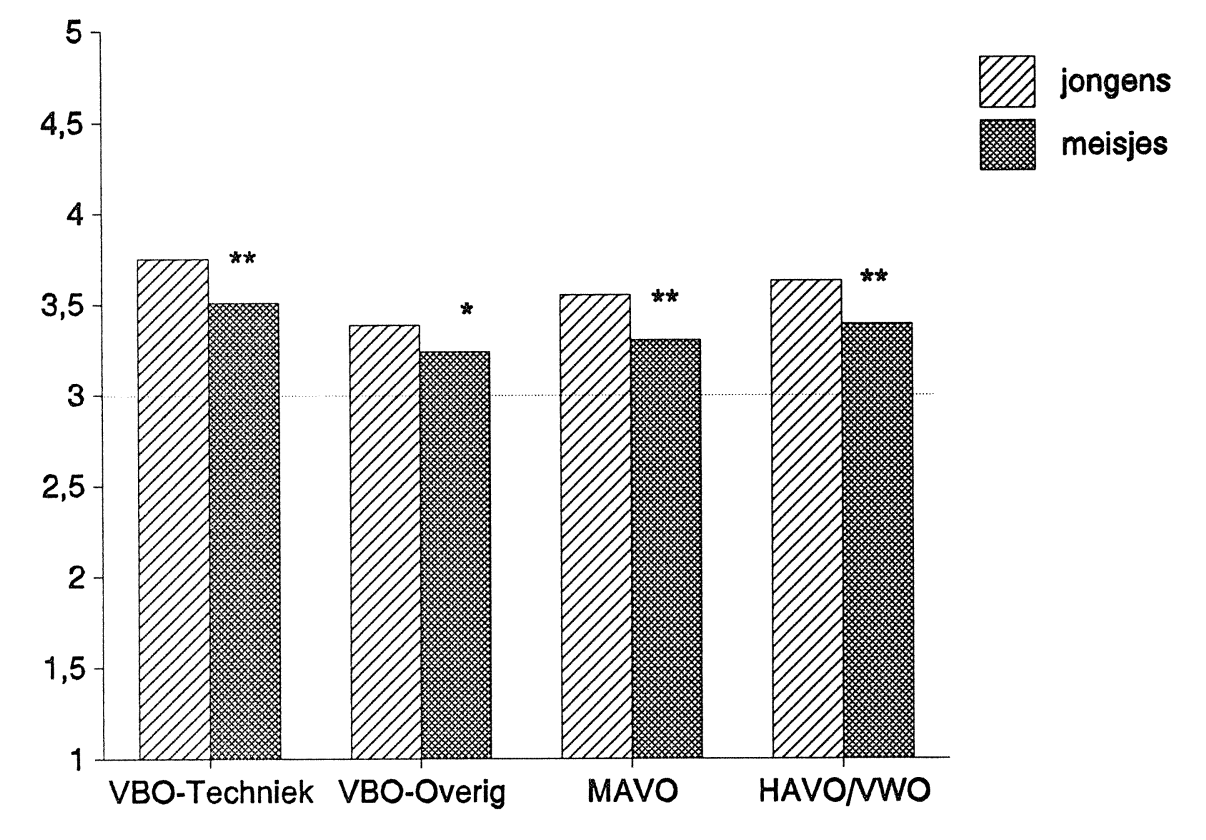

* = significant $5 \%$-niveau; ${ }^{*}=$ significant $1 \%$-niveau

a score groter dan 3 drukt positieve attitude uit

Ook voor dit element van de techniek-waarderingsschaal is een multivariaat model opgesteld. Daarbij zijn dezelfde onafhankelijke variabelen gebruikt als in paragraaf 3.3. De schattingsresultaten in tabel 3.5. laten zien dat met behulp van de opgenomen variabelen slechts een beperkt deel van de variantie in de gemiddelde waarderingsscores van de leerlingen kan worden verklaard. Dit heeft waarschijnlijk mede te maken met het feit dat deze variantie niet erg hoog is en dus een vrij groot gedeelte van de heterogeniteit samenhangt met de min of meer toevallige spreiding van de antwoorden die altijd bij dergelijk onderzoek zal optreden.

Uit de tabel kan wel wederom worden geconstateerd dat meisjes een negatiever beeld hebben van de maatschappelijke consequenties van techniek dan jongens. In tegenstelling tot de resultaten met betrekking tot de interesse voor techniek, blijkt de houding van de leerlingen ten opzichte van de consequenties van technologische vernieuwing niet samen te hangen met de rapportcijfers voor A- of B-vakken. Opvallend is verder dat de VBO-Overig-leerlingen in het zuiden en oosten en de HAVO/VWO-leerlingen in het zuiden van het land significant positiever tegenover techniek staan. 
Tabel 3.5. Schattingsresultaten van een multivariate analyse van de houding ten opzichte van de consequenties van technologische ontwikkelingen naar opleidingscategorie (standaardfouten tussen haakjes)

\begin{tabular}{|c|c|c|c|c|c|c|c|c|}
\hline \multirow{2}{*}{$\begin{array}{l}\begin{array}{l}\text { Onafhankelijke } \\
\text { variabele }\end{array} \\
\text { constante }\end{array}$} & \multicolumn{2}{|c|}{ VBO-Techniek } & \multicolumn{2}{|c|}{ VBO-Overig } & \multicolumn{2}{|c|}{ MAVO } & \multicolumn{2}{|c|}{ HAVO/VWO } \\
\hline & $3,80^{* *}$ & $(0,11)$ & $3,35^{\prime \prime}$ & $(0,13)$ & $2,93^{* *}$ & $(0,31)$ & $3,36^{* *}$ & $(0,31)$ \\
\hline geslacht & $-0,29^{*}$ & $(0,09)$ & $-0,14^{\prime \prime}$ & $(0,06)$ & $-0,24 *$ & $(0,06)$ & $-0,16^{* *}$ & $(0,06)$ \\
\hline etniciteit & $-0,10$ & $(0,08)$ & 0,09 & $(0,09)$ & $-0,14$ & $(0,11)$ & $-0,08$ & $(0,11)$ \\
\hline rapportcijfers A-vakken & n.v.t. & & n.v.t. & & 0,02 & $(0,04)$ & $-0,02$ & $(0,04)$ \\
\hline rapportcijfers B-vakken & n.v.t. & & n.v.t. & & 0,06 & $(0,04)$ & 0,06 & $(0,03)$ \\
\hline \multicolumn{9}{|l|}{ Regio } \\
\hline noord & $-0,10$ & $(0,08)$ & 0,01 & $(0,11)$ & 0,13 & $(0,12)$ & $-0,12$ & $(0,08)$ \\
\hline oost & 0,11 & $(0,08)$ & $0,17^{*}$ & $(0,08)$ & $-0,11$ & $(0,08)$ & \multirow{2}{*}{\multicolumn{2}{|c|}{ referentie }} \\
\hline west & \multicolumn{2}{|c|}{ referentie } & \multicolumn{2}{|c|}{ referentie } & \multicolumn{2}{|c|}{ referentie } & & \\
\hline zuid & $-0,01$ & $(0,07)$ & $0,14^{\circ}$ & $(0,06)$ & 0,02 & $(0,07)$ & $0,15^{*}$ & $(0,06)$ \\
\hline \multicolumn{9}{|l|}{ Typering van de leerling } \\
\hline met mensen omgaan & $-0,13$ & $(0,07)$ & 0,07 & $\begin{array}{l}(0,06) \\
(0,07)\end{array}$ & $\begin{array}{l}-0,00 \\
-0,01\end{array}$ & $\begin{array}{l}(0,07) \\
(0,07)\end{array}$ & $\begin{array}{l}0,02 \\
0,08\end{array}$ & $(0,07)$ \\
\hline $\begin{array}{l}\text { carrière maken } \\
\text { nuttig werk doen }\end{array}$ & \multicolumn{2}{|c|}{ referentie } & \multicolumn{2}{|c|}{ referentie } & \multicolumn{2}{|c|}{ referentie } & \multicolumn{2}{|c|}{ referentie } \\
\hline \multicolumn{9}{|l|}{ Opleidingsniveau vader } \\
\hline Algemeen onderwijs & \multicolumn{2}{|c|}{ referentie } & \multicolumn{2}{|c|}{ referentie } & \multicolumn{2}{|c|}{ referentie } & \multicolumn{2}{|c|}{ referentie } \\
\hline Lager beroepsonderwijs & 0,05 & $(0,07)$ & 0,08 & $(0,08)$ & $-0,04$ & $(0,09)$ & 0,10 & $(0,08)$ \\
\hline Middelbaar beroepsonderwijs & $-0,00$ & $(0,11)$ & 0,13 & $(0,13)$ & $-0,13$ & $(0,12)$ & $-0,19$ & $(0,11)$ \\
\hline Hoger onderwijs & 0,08 & $(0,12)$ & $-0,14$ & $(0,16)$ & 0,08 & $(0,10)$ & 0,10 & $(0,07)$ \\
\hline anders/weet niet & 0,01 & $(0,08)$ & $-0,06$ & $(0,09)$ & $-0,08$ & $(0,08)$ & $-0,20^{*}$ & $(0,09)$ \\
\hline \multicolumn{9}{|l|}{ Opleidingsniveau moeder } \\
\hline Algemeen onderwijs & \multicolumn{2}{|c|}{ referentie } & \multicolumn{2}{|c|}{ referentie } & \multicolumn{2}{|c|}{ referentie } & \multicolumn{2}{|c|}{ referentie } \\
\hline Lager beroepsonderwijs & $-0,02$ & $(0,07)$ & $-0,02$ & $(0,08)$ & 0,02 & $(0,07)$ & 0,03 & $(0,08)$ \\
\hline Middelbaar beroepsonderwijs & $-0,16$ & $(0,14)$ & $-0,03$ & $(0,14)$ & 0,17 & $(0,10)$ & $-0,15$ & $(0,09)$ \\
\hline Hoger onderwijs & 0,35 & $(0,25)$ & 0,18 & $(0,24)$ & $-0,18$ & $(0,20)$ & 0,06 & $(0,08)$ \\
\hline anders/weet niet & $-0,04$ & $(0,07)$ & $-0,11$ & $(0,09)$ & 0,09 & $(0,09)$ & 0,17 & $(0,10)$ \\
\hline Beroepsrichting vader & & & & & & & & \\
\hline technisch & $-0,01$ & $(0,06)$ & 0,04 & $(0,07)$ & $-0,05$ & $(0,08)$ & $0,17^{\circ}$ & $(0,07)$ \\
\hline verzorgend & $-0,05$ & $(0,11)$ & $-0,10$ & $(0,11)$ & $-0,12$ & $(0,12)$ & 0,10 & $(0,09)$ \\
\hline overig & refere & & refere & & refere & & referen & tie \\
\hline weet niet & 0,01 & $(0,12)$ & 0,01 & $(0,13)$ & $-0,08$ & $(0,16)$ & 0,12 & $(0,17)$ \\
\hline Beroepsrichting moeder & & & & & & & & \\
\hline technisch & 0,11 & $(0,17)$ & $-0,12$ & $(0,18)$ & 0,05 & $(0,20)$ & $\begin{array}{l}-0,24 \\
-0,15 *\end{array}$ & $(0,23)$ \\
\hline $\begin{array}{l}\text { economisch } \\
\text { medisch/dienstverl./ }\end{array}$ & & $(0,10)$ & $-0,05$ & $(0,11)$ & 0,03 & $(0,12)$ & $-0,15^{*}$ & $(0,07)$ \\
\hline verzorgend & $-0,01$ & $(0,09)$ & $-0,15$ & $\begin{array}{l}(0,09) \\
\text { tie }\end{array}$ & $\begin{array}{l}0,13 \\
\text { refere }\end{array}$ & $\begin{array}{l}(0,11) \\
\text { tie }\end{array}$ & $\begin{array}{l}-0,17^{*} \\
\quad \text { referen }\end{array}$ & $(0,08)$ \\
\hline nooit beroep gehad/ & & & & & & & & \\
\hline weet niet & $-0,01$ & $(0,09)$ & $-0,07$ & $(0,10)$ & 0,19 & $(0,12)$ & $-0,31^{* *}$ & $(0,10)$ \\
\hline$n$ & 455 & & 363 & & 330 & & 328 & \\
\hline $\mathrm{R}^{2}$ & 0,08 & & 0,13 & & 0,15 & & 0,21 & \\
\hline
\end{tabular}


Evenals de interesse voor techniek, bestaat er ook nauwelijks een relatie tussen de houding ten opzichte van de mogelijke consequenties van technologische ontwikkeling en het opleidingsniveau van de ouders. Wel laat de tabel zien dat HAVO/VWO-leerlingen, waarvan de moeder een economisch of medisch beroep uitoefent of heeft uitgeoefend een significant negatievere houding aannemen ten aanzien van de mogelijke gevolgen van technologische vernieuwing. Tot slot kan worden opgemerkt dat het beroep van de vader eveneens meespeelt bij de houding van de leerlingen. HAVO/VWO-scholieren met een vader die in de techniek werkzaam is (geweest) hebben een significant positiever beeld van de economische en maatschappelijke consequenties van techniek.

\subsection{Meisjes en techniek}

Het laatste element van de techniek-waarderingsschaal is de attitude van de leerlingen ten opzichte van de rol van meisjes in de techniek. Dit onderdeel is door middel van vier items in de vragenlijst opgenomen. Tabel 3.6. geeft een beeld van de gemiddelde scores van jongens en meisjes. Het blijkt dat de houding van jongeren op dit punt erg positief is. Wel hebben meisjes daarbij doorgaans nog een iets positiever beeld dan jongens.

Tabel 3.6. Houding ten opzichte van meisjes en techniek naar geslacht ${ }^{\mathrm{a}}$

Item jongens meisjes

Een meisje kan best een technisch beroep hebben

$4,45 \quad 4,73$

Jongens zijn meer geschikt om technische dingen te doen dan meisjes

a score groter dan 3 drukt positieve attitude uit

De stelling 'Een meisje kan best een technisch beroep hebben' wordt door maar liefst twee derde van de jongens en ruim $80 \%$ van de meisjes positief beoordeeld, resulterend in een gemiddelde itemscore van respectievelijk 4,45 en 4,73 . Ongeveer $60 \%$ van zowel de jongens als de meisjes vindt dat er meer meisjes in de techniek zouden moeten werken. Opvallend is daarbij dat meisjes dit niet vaker vinden dan jongens. Waarschijnlijk hangt dit samen met het interesse-aspect, dat reeds in paragraaf 3.3. aan de orde is geweest. De houding ten opzichte van de beide andere items is - ofschoon duidelijk positief - iets minder gunstig. Mogelijk kan dit worden verklaard door een dubbele interpretatiemogelijkheid van de desbetreffende items. Aan de ene kant kan men de beweringen beschouwen als eventuele verschillen in potentieel tussen jongens en meisjes, maar aan de andere kant ook als de feitelijke performance van jongens en meisjes. In dit laatste geval wordt het beeld vanzelfsprekend in belangrijke mate bepaald door het feit dat jongens op dit moment vaker een technische richting kiezen dan meisjes en dus ook meer kennis van de techniek zullen opdoen. 
Figuur 3.3. geeft vervolgens wederom een grafische weergave van de waarderingsscore, verdeeld naar opleidingscategorie en geslacht. Het in de tabel al duidelijk zichtbare beeld, wordt in deze figuur nogmaals voor alle opleidingscategorieën bevestigd. Tussen de vier opleidingscategorieën bestaat er wat dit betreft vrijwel geen verschil. Al met al kan worden geconcludeerd dat 'meisjes en techniek' eigenlijk geen item meer is onder de Nederlandse jeugd. Vrijwel iedereen is het erover eens dat meisjes best in de techniek werkzaam kunnen zijn.

Figuur 3.3. Houding ten opzichte van meisjes en techniek naar opleidingscategorie en geslacht

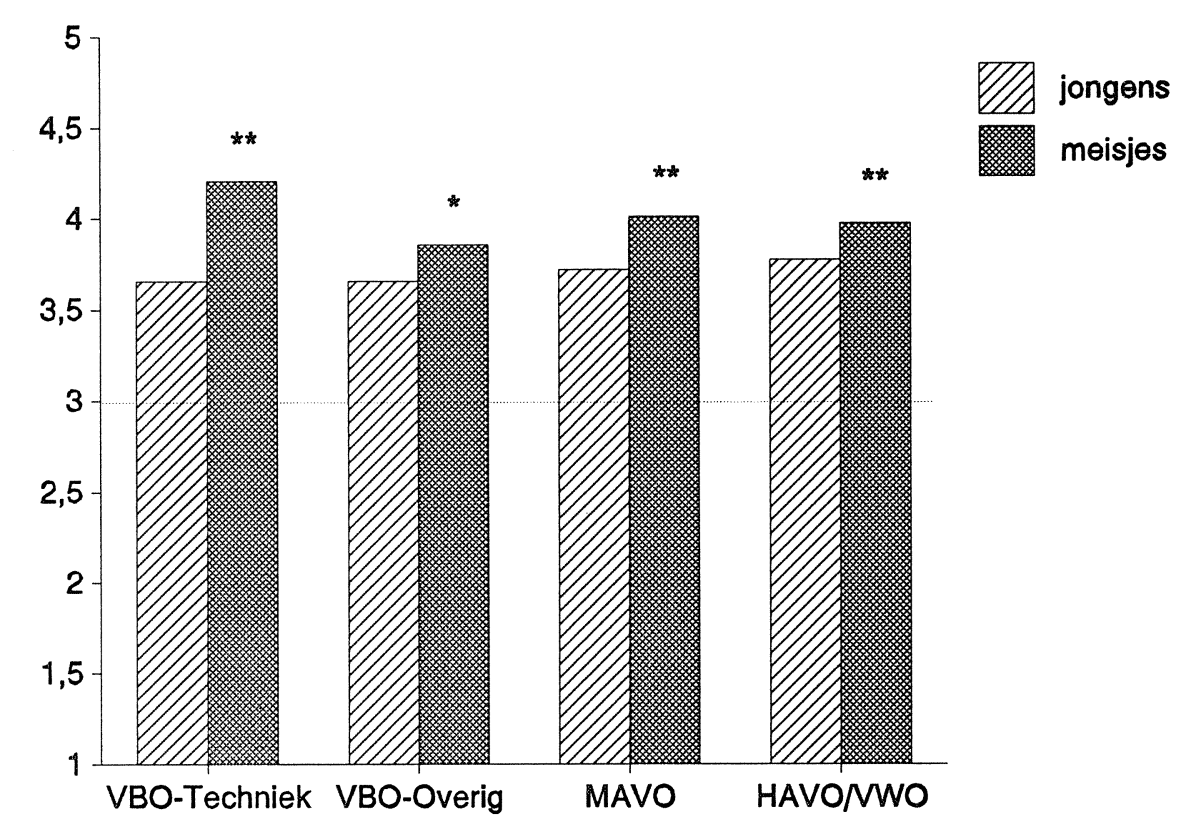

* = significant $5 \%$-niveau; ${ }^{*}=$ significant $1 \%$-niveau

a score groter dan 3 drukt positieve attitude uit

Tabel 3.7. geeft een beeld van de resultaten van de multivariate analyses. Ook hier blijkt dat slechts een klein deel van de variantie in de gemiddelde waarderingsscores met behulp van de opgenomen onafhankelijke variabelen kan worden verklaard. In de schattingsresultaten kan men wel terug zien dat voor alle vier de onderscheiden opleidingscategorieën geldt dat meisjes iets positiever tegenover de mogelijke rol van vrouwen in de techniek aankijken dan jongens. Het verschil bij het HAVO/VWO is echter niet significant. Verder is het opvallend dat etnische minderheden significant negatiever staan ten opzichte van het werken van meisjes in de techniek ${ }^{7}$. Wel kan hierbij worden opgemerkt dat onder jongeren uit de etnische minderheidsgroepen vaak überhaupt een traditioneel beeld bestaat van de rol van mannen en vrouwen in de

7. Dit kan met name worden geconstateerd bij de VBO-leerlingen; de enquête bevat overigens weinig leerlingen vanuit de groepen etnische minderheden voor de opleidingscategorieën MAVO en HAVO/VWO. 
Tabel 3.7. Schattingsresultaten van een multivariate analyse van de houding ten opzichte van meisjes en techniek naar opleidingscategorie (standaardfouten tussen haakjes)

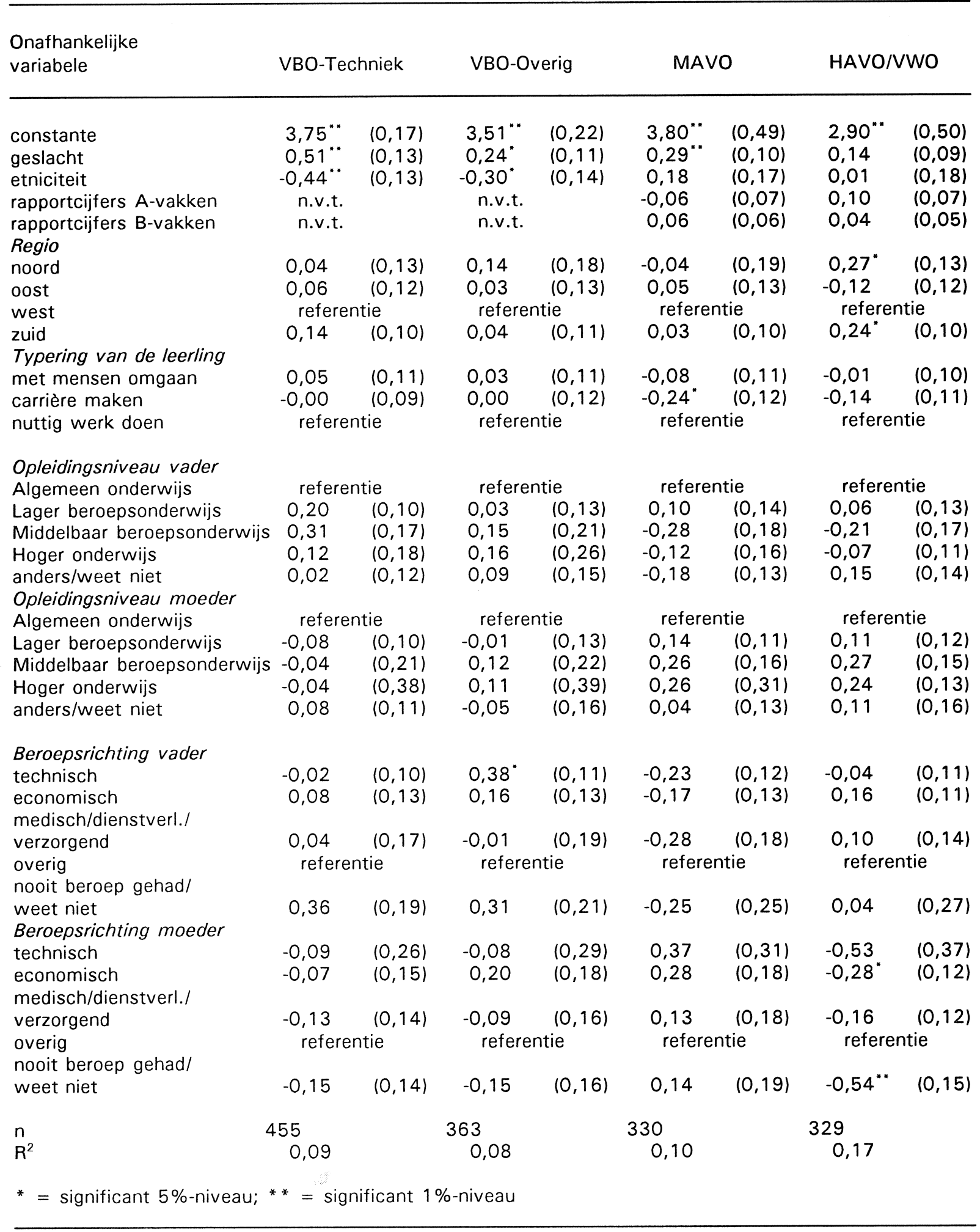


$-28-$

maatschappij. Daarnaast blijkt uit de tabel dat de MAVO-leerlingen die een goede carrière voor zichzelf erg belangrijk vinden negatiever staan tegenover de rol van meisjes in de techniek. Tenslotte wordt vermeld dat bij het VBO-Overig geldt dat de leerlingen met een technische vader significant positiever aankijken tegen 'meisjes en techniek'. 


\section{WAARDERING VAN ENKELE SPECIFIEKE TECHNOLOGIEËN}

$\mathrm{Na}$ de meer algemene waarde-oriëntatie ten aanzien van techniek, waaraan in het vorige hoofdstuk aandacht is besteed, wordt in dit hoofdstuk ingegaan op de waardering van jongeren van enkele specifieke technologieën. Uit soortgelijk onderzoek dat in 1985 is uitgevoerd onder de bevolking van 16 jaar en ouder bleek dat de oordelen over de verschillende vormen van technologische ontwikkelingen nogal uit elkaar lopen (Knulst en Van Beek, 1988; zie ook Ministerie van Onderwijs en Wetenschappen en Ministerie van Economische Zaken, 1991).

In dit hoofdstuk zullen vier soorten van technologische ontwikkeling nader worden bekeken. Achtereenvolgens zullen de volgende kerntechnologieën ${ }^{8}$ aan de orde komen:

- nieuwe apparaten;

- informatietechnologie;

- $\quad$ kernenergie;

- milieutechnologie.

Voor deze vier technologieën is telkens een blokje van vijf beweringen in de vragenlijst opgenomen. Bij elke bewering hebben de leerlingen op een vijfpuntsschaal moeten aangeven in hoeverre zij het daarmee eens zijn. Vier van de vijf opgenomen items zijn daarbij voor alle vormen van technologische innovatie gelijk. Telkens is één bewering op de desbetreffende technologie toegespitst.

Tabel 4.1. Waardering van 'nieuwe apparaten' naar opleidingscategorie en geslacht ${ }^{\mathrm{a}}$

\begin{tabular}{|c|c|c|c|c|c|c|c|c|}
\hline & \multicolumn{2}{|c|}{ VBO-Techniek } & \multicolumn{2}{|c|}{ VBO-Overig } & \multicolumn{2}{|c|}{ MAVO } & \multicolumn{2}{|c|}{ HAVO/VWO } \\
\hline & j & $\mathrm{m}$ & j & $\mathrm{m}$ & j & m & j & $\mathrm{m}$ \\
\hline $\begin{array}{l}\text { Ik zou graag meer over nieuwe } \\
\text { apparaten willen weten }\end{array}$ & 4,03 & 3,28 & 3,64 & 3,24 & 3,96 & 3,22 & 3,97 & 3,18 \\
\hline $\begin{array}{l}\text { Nieuwe apparaten zijn goed voor de } \\
\text { economie van ons land }\end{array}$ & 3,84 & 3,43 & 3,53 & 3,34 & 3,81 & 3,36 & 3,80 & 3,49 \\
\hline $\begin{array}{l}\text { Nieuwe apparaten veroorzaken een } \\
\text { hoge werkloosheid }\end{array}$ & 2,96 & 2,92 & 2,91 & 2,87 & 3,09 & 2,91 & 3,28 & 2,92 \\
\hline $\begin{array}{l}\text { Nieuwe apparaten maken het leven } \\
\text { niet aangenamer }\end{array}$ & 3,53 & 3,19 & 3,55 & 3,25 & 3,79 & 3,67 & 4,00 & 3,62 \\
\hline $\begin{array}{l}\text { Nieuwe apparaten zijn al met al } \\
\text { een goede zaak }\end{array}$ & 3,69 & 3,40 & 3,60 & 3,38 & 3,63 & 3,39 & 3,77 & 3,48 \\
\hline
\end{tabular}

De score op de items met betrekking tot de waardering van 'nieuwe apparaten'9 is per opleidingscategorie en geslacht weergegeven in tabel 4.1. De interesse voor nieuwe apparaten blijkt vrij groot te zijn. Ruim $70 \%$ van de jongens en bijna $40 \%$ van de meisjes wil graag meer

8. Vergelijk bijvoorbeeld Central Planning Bureau (1992).

9. Als voorbeelden zijn daarbij in de vragenlijst de CD-speler en de magnetron-oven genoemd. 
van nieuwe apparaten weten. Ook de economische gevolgen van de introductie van nieuwe apparaten worden door de leerlingen positief ingeschat, waarbij men overigens per saldo noch positief noch negatief reageert op de stelling dat nieuwe apparaten een hoge werkloosheid veroorzaken. Verder zijn de leerlingen in het algemeen van mening dat nieuwe apparaten het leven sterk veraangenamen. Mede daardoor komen zij waarschijnlijk tot de conclusie dat nieuwe apparaten al met al een goede zaak zijn.

Ook hier blijkt dat jongens de technologische ontwikkeling hoger waarderen dan meisjes. Op alle items en voor alle opleidingscategorieën is de score op de waarderingsschaal bij jongens hoger dan bij meisjes. Wel is het opvallend dat de HAVO/VWO-leerlingen nieuwe apparaten hoger waarderen dan de andere leerlingen. In meer algemene zin is immers gebleken dat VBOTechniek-leerlingen de hoogste waardering voor techniek hebben.

Een tweede specifieke technologie die in de enquête is behandeld betreft de informatietechnologie ${ }^{10}$. De score van de leerlingen op de diverse items is gepresenteerd in tabel 4.2. De interesse voor deze vorm van technologische ontwikkeling is opvallenderwijs veel minder groot dan de interesse voor nieuwe apparaten. Met name meisjes geven aan dat zij niet zo in informatietechnologie zijn geïnteresseerd.

Tabel 4.2. Waardering van informatietechnologie naar opleidingscategorie en geslacht ${ }^{\mathrm{a}}$

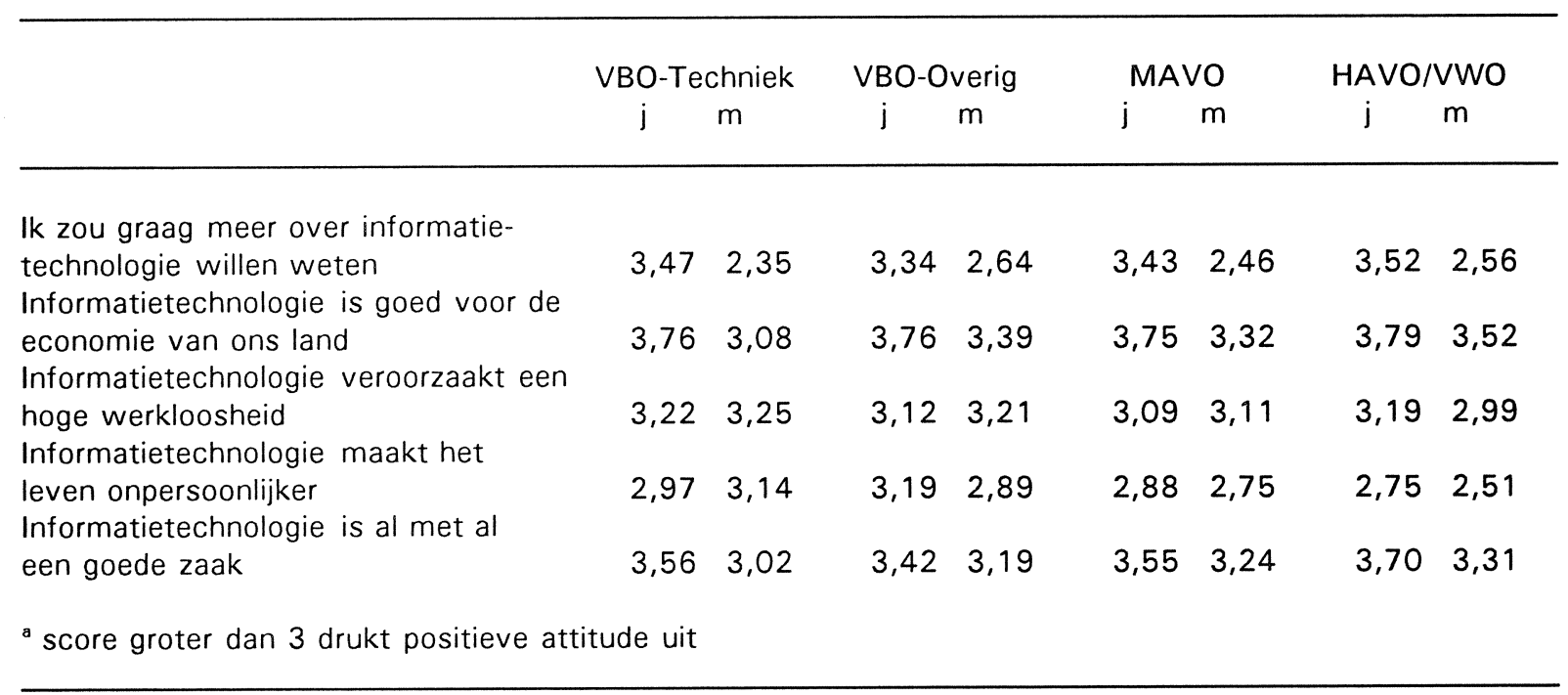

Het economische belang van informatietechnologie wordt door een groot deel van de leerlingen erkend. De score op het item 'Informatietechnologie is goed voor de economie van ons land' is vrij hoog. Daarentegen heeft men - evenals bij de waardering van nieuwe apparaten - geen uitgesproken positief of negatief beeld van de gevolgen van informatietechnologie voor de werkloosheid. Een belangrijke negatieve consequentie van de computerisering die nogal eens wordt genoemd is het onpersoonlijker worden van de samenleving. Ook door de jongeren wordt

10. In de vragenlijst is daaraan toegevoegd "(b.v. computers)". 
dit als bezwaar van informatietechnologie gezien, getuige hun reactie op het desbetreffende item. Ondanks dit negatieve aspect van de informatietechnologie zijn de leerlingen al met al toch vrij gunstig gestemd over deze technologie.

Met betrekking tot de verschillen tussen jongens en meisjes ten aanzien van de waardering van informatietechnologie kan worden opgemerkt dat ook hier het beeld geldt dat de waardering van jongens in het algemeen hoger is dan de waardering van meisjes. Een opvallende uitzondering is daarbij dat de vrouwelijke VBO-Techniek-leerlingen het onpersoonlijker worden van het leven door de informatietechnologie minder pessimistisch inzien dan de jongens op deze opleiding. Verder kan worden vastgesteld dat informatietechnologie, evenals 'nieuwe apparaten' al met al het hoogst door de HAVO/VWO-leerlingen wordt gewaardeerd.

Tabel 4.3. Kennis en waardering van kernenergie naar opleidingscategorie en geslacht ${ }^{\mathrm{a}}$

\begin{tabular}{|c|c|c|c|c|c|c|c|c|}
\hline & \multicolumn{2}{|c|}{ VBO-Techniek } & \multicolumn{2}{|c|}{ VBO-Overig } & \multicolumn{2}{|c|}{ MAVO } & \multicolumn{2}{|c|}{ HAVO/VWO } \\
\hline & j & $\mathrm{m}$ & j & m & $\mathrm{j}$ & m & $\mathrm{j}$ & m \\
\hline & $\%$ & $\%$ & $\%$ & $\%$ & $\%$ & $\%$ & $\%$ & $\%$ \\
\hline \multicolumn{9}{|l|}{ Kennis } \\
\hline wel eens gehoord van kernenergie & 94 & 93 & 94 & 89 & 95 & 91 & 100 & 99 \\
\hline nog nooit gehoord van kernenergie & 6 & 7 & 6 & 11 & 5 & 9 & 0 & 1 \\
\hline $\begin{array}{l}\mathrm{N} \\
\text { Cramer's V }\end{array}$ & \multicolumn{2}{|c|}{0,01} & \multicolumn{2}{|c|}{0,07} & \multicolumn{2}{|c|}{$0,09^{*}$} & \multicolumn{2}{|c|}{0,06} \\
\hline
\end{tabular}

\section{Waardering}

Ik zou graag meer over kernenergie willen weten

Kernenergie is goed voor de economie van ons land

$3,28 \quad 3,03$

$3,24 \quad 2,85$

$3,212,62$

$3,50 \quad 3,06$

Kernenergie veroorzaakt een hoge werkloosheid

Kernenergie is slecht voor het milieu kernenergie is al met al een goede zaak
$2,42 \quad 2,71$

$3,35 \quad 3,24$

$2,05 \quad 2,10$

$2,48 \quad 2,42$
$3,08 \quad 3,20$

$2,05 \quad 2,07$

$2,39 \quad 2,47$
$2,71 \quad 2,52$

$3,07 \quad 2,63$

$3,32 \quad 3,25$

$2,00 \quad 1,96$

$3,473,20$

$2,26 \quad 1,93$

$2,79 \quad 2,31$

${ }^{a}$ score groter dan 3 drukt positieve attitude uit

De derde specifieke technologie is kernenergie. Terwijl er in de enquête vanuit is gegaan dat de leerlingen weten wat met 'nieuwe apparaten' en informatietechnologie wordt bedoeld, is voor kernenergie expliciet gevraagd of men daarvan al eens eerder had gehoord. Uit tabel 4.3. blijkt dat de bekendheid met kernenergie in het algemeen redelijk groot is. Wel kan worden geconstateerd dat VBO-leerlingen iets minder vaak over deze technologie hebben gehoord. Verder is het opvallend dat voor het MAVO geldt dat meisjes significant iets minder bekend zijn 
met kernenergie dan jongens.

Uit de tabel blijkt verder dat de interesse voor kernenergie redelijk te noemen is. Daarbij blijkt dat meisjes wederom minder interesse voor deze vorm van technologische innovatie hebben dan jongens. Ongeveer $40 \%$ van alle jongeren blijkt graag meer over kernenergie te willen weten. Wel is het opvallend dat meisjes vaker meer willen weten van kernenergie dan van informatietechnologie. Het belang van kernenergie voor de economische ontwikkeling van ons land wordt door de Nederlandse jeugd betwijfeld. Voor een toenemende werkloosheid wordt daarbij overigens niet gevreesd. Als het meest negatieve aspect van kernenergie wordt het mogelijke milieuvervuilende karakter ervan gezien. Zeer waarschijnlijk is dit ook de doorslaggevende reden waarom de jongeren het gebruiken van kernenergie al met al een slechte ontwikkeling vinden.

In het algemeen kan worden opgemerkt dat de waardering voor kernenergie bij jongens groter is dan bij meisjes. Een uitzonderingspositie wordt daarbij ingenomen door het VBO-Overig. Behalve bij het item 'Ik zou graag meer over kernenergie willen weten' scoren meisjes op alle items hoger dan jongens. Ook deze vorm van technologische ontwikkeling wordt door de jongens van het HAVO/VWO het meest gunstig gewaardeerd. Bij meisjes is niet eenduidig vast te stellen welke opleidingscategorie de meeste waardering voor kernenergie heeft.

De laatste vorm van technologische ontwikkeling die in dit hoofdstuk aan de orde komt heeft betrekking op milieutechnologie. Ook hierbij is aan de leerlingen eerst gevraagd of zij al eens eerder van de desbetreffende technologie hadden gehoord. Het blijkt uit tabel 4.4. dat meer dan de helft van de leerlingen nog nooit van milieutechnologie heeft gehoord ${ }^{11}$. Daarbij kan worden opgemerkt dat de kennis over dit onderwerp bij meisjes lager is dan bij jongens ${ }^{12}$ en dat HAVO/VWO-leerlingen aangeven vaker van deze vorm van technologie te hebben gehoord $^{13}$. Gezien dit resultaat moeten de waarderingsscores op de verschillende items voorzichtig worden geïnterpreteerd. Veel leerlingen hebben namelijk - waarschijnlijk uit onbekendheid met het onderwerp - neutraal gereageerd op de geponeerde beweringen.

Uit de tabel komt desondanks naar voren dat de waardering voor milieutechnologie vrij hoog is. Mogelijk zou dit kunnen samenhangen met het feit dat het woord 'milieu' een erg positief beeld bij de leerlingen oproept. Verder blijkt dat de jongeren gereserveerd staan tegenover de vraag of het leven veel duurder wordt als gevolg van het gebruik van milieutechnologie. Hierbij kan worden opgemerkt dat de waardering voor technologie hoger is wanneer alleen wordt gekeken naar de leerlingen die aangeven wel eens van milieutechnologie te hebben gehoord.

11. Overigens was in de proefenquête ook nog een blokje vragen over biotechnologie opgenomen. Ook daarbij bleek dat een groot gedeelte van de leerlingen niet wist wat dat was.

12. Het is natuurlijk ook mogelijk dat meisjes vaker 'toegeven' dat zij nog nooit van milieutechnologie hebben gehoord.

13. Tussen deze beide opleidingen blijkt er overigens nauwelijks verschil op dit punt te bestaan. 
Tabel 4.4. Kennis en waardering van milieutechnologie naar opleidingscategorie en geslacht ${ }^{\mathrm{a}}$

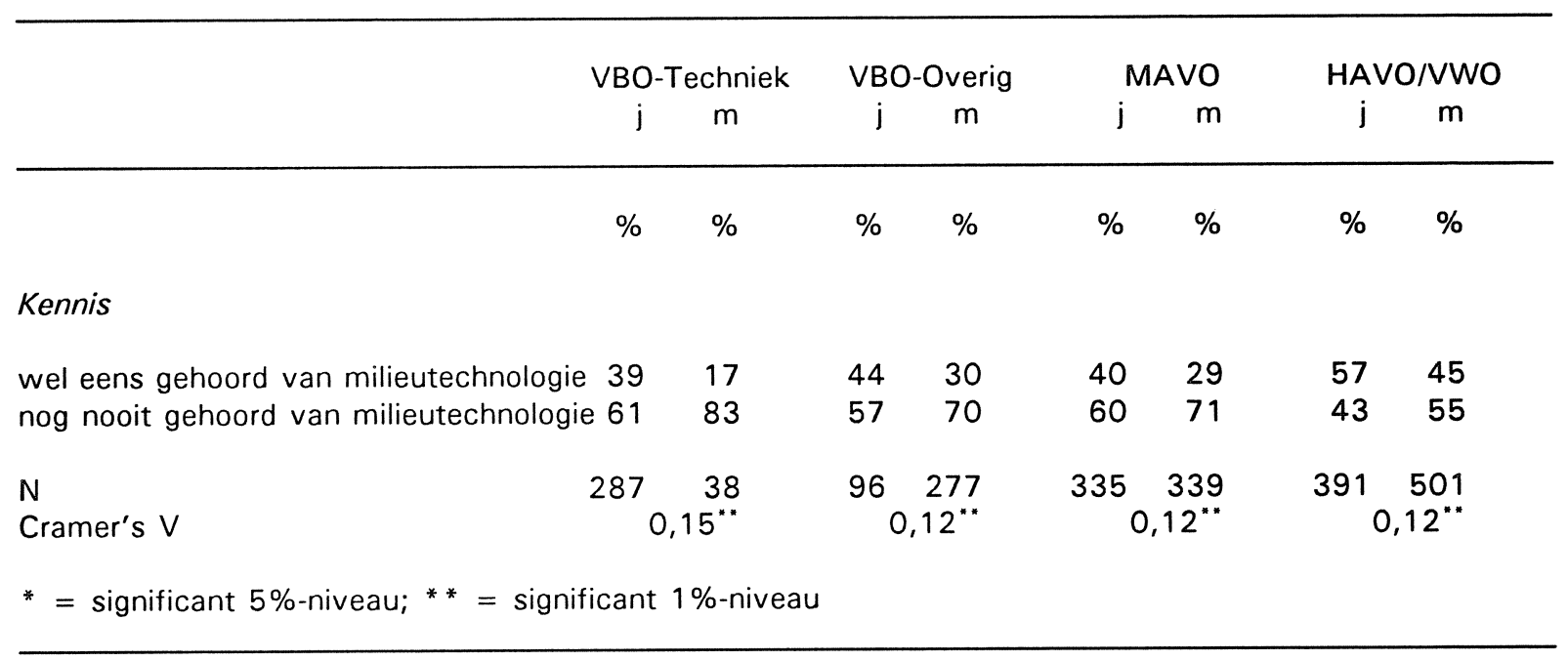

Waardering

Ik zou graag meer over milieutechnologie willen weten Milieutechnologie is goed voor de economie van ons land Milieutechnologie veroorzaakt een hoge werkloosheid

Milieutechnologie maakt het leven erg duur

Milieutechnologie is al met al een goede zaak

$\begin{array}{ll}3,58 & 3,28 \\ 3,52 & 3,15 \\ 3,35 & 3,34 \\ 2,80 & 3,06 \\ 3,64 & 3,27\end{array}$
$3,40 \quad 3,14$

$3,52 \quad 3,18$

$3,42 \quad 3,25$

$3,52 \quad 3,28$

$3,40 \quad 3,28$

$3,42 \quad 3,29$

${ }^{a}$ score groter dan 3 drukt positieve attitude uit

In het vervolg van dit hoofdstuk worden de vier onderscheiden technologieën nogmaals per item bekeken. Figuur 4.1. geeft aan hoe groot de interesse van de leerlingen voor de verschillende vormen van technologische ontwikkeling is. 'Nieuwe apparaten' mogen zich in de meeste interesse van de Nederlandse jeugd verheugen. Relatief veel leerlingen willen ook graag meer weten over milieutechnologie. Opvallend daarbij is dat ook meisjes redelijk zijn geïnteresseerd in beide technologieën, ofschoon hun interesse op dit punt wel significant lager is dan die van jongens. Het verschil in interesse is echter veel pregnanter bij informatietechnologie. Terwijl jongens een betrekkelijk grote interesse in deze technologie tonen, zeggen meisjes daarentegen dat dit hen vrijwel niet interesseert. Van de vier onderscheiden technologieën interesseert deze hen het minste. Jongens hebben het minste interesse in kernenergie.

In figuur 4.2. wordt een overzicht gegeven van de mogelijke economische gevolgen van de verschillende technologieën, zoals die door de leerlingen worden ingeschat. Zowel jongens als meisjes vinden dat de meeste technologieën goed zijn voor de economische ontwikkeling van ons land. Wel geldt daarbij dat meisjes een negatiever beeld van de gevolgen voor de economie hebben dan jongens. De betekenis van nieuwe apparaten en informatietechnologie voor de economie wordt door de Nederlandse jongeren het meest positief ingeschat. Ook van 
Figuur 4.1. De interesse voor enkele technologische ontwikkelingen naar geslacht ${ }^{\mathrm{a}}$

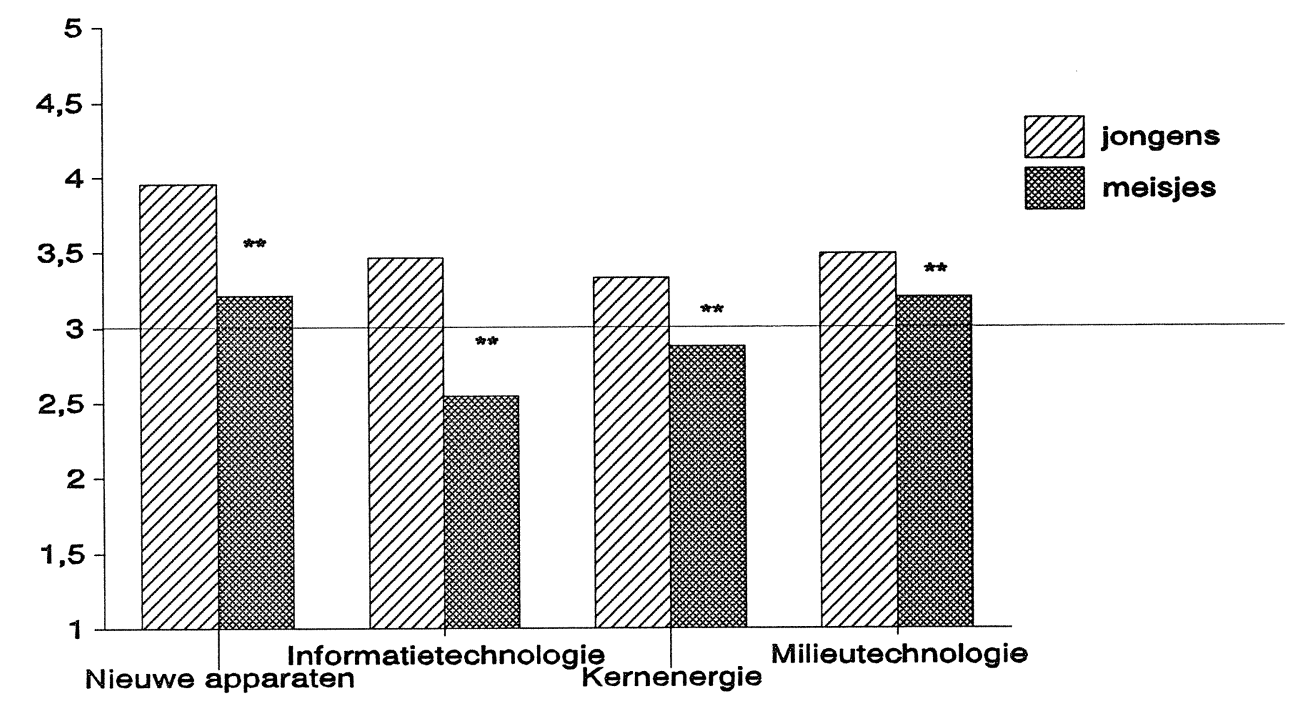

* = significant $5 \%$-niveau; ** = significant $1 \%$-niveau

a score groter dan 3 drukt positieve attitude uit

Figuur 4.2. De inschatting van de economische gevolgen van enkele technologische ontwikkelingen naar geslacht $^{\mathrm{a}}$

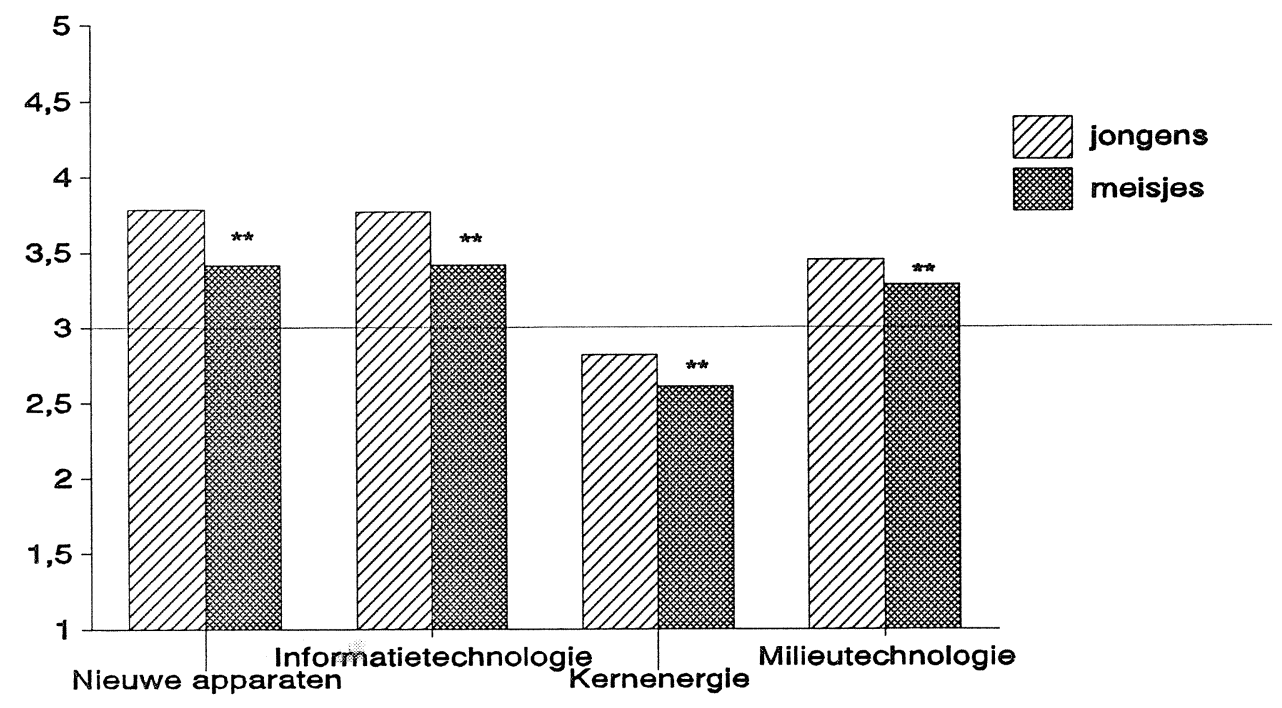

* = significant $5 \%$-niveau; * $=$ significant $1 \%$-niveau

a score groter dan 3 drukt positieve attitude uit 
milieutechnologie denkt men dat deze per saldo een gunstige invloed heeft op de Nederlandse economie. Alleen kernenergie kan volgens de jeugd niets toevoegen aan de economische positie van ons land.

Uit figuur 4.3. blijkt dat de leerlingen niet denken dat door het gebruik maken van nieuwe technologieën de werkloosheid zal stijgen. Voor alle onderscheiden technologieën verwachten de jongeren een in lichte mate gunstig effect op de werkloosheid. De leerlingen hebben daarbij het meest positieve beeld van milieutechnologie. Het minst positief denkt men over nieuwe apparaten.

Figuur 4.3. De inschatting van de gevolgen voor de werkloosheid van enkele technologische ontwikkelingen naar geslacht ${ }^{\mathrm{a}}$

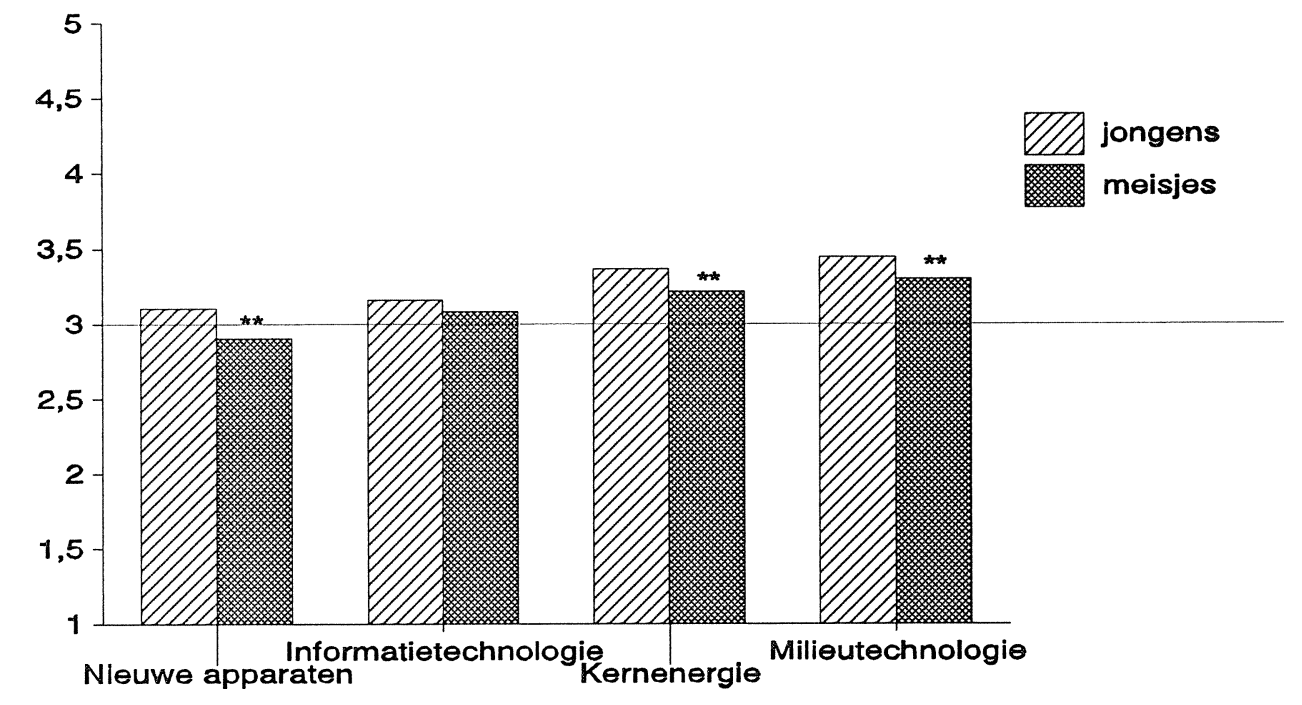

* = significant $5 \%$-niveau; * ${ }^{*}=$ significant $1 \%$-niveau

a score groter dan 3 drukt positieve attitude uit

Figuur 4.4. geeft tenslotte een overzicht van de algehele waardering van de Nederlandse jeugd over de vier vormen van technologische ontwikkeling. De figuur is daarbij gebaseerd op de scores op het item 'is al met al een goede zaak'. Het blijkt dat drie van de vier technologieën vrij positief worden gewaardeerd. Nieuwe apparaten en milieutechnologie mogen op de meeste sympathie van de jongeren rekenen. Ook informatietechnologie mag zich in een redelijke waardering verheugen. De leerlingen staan wel negatief tegenover kernenergie. Zoals hierboven reeds is aangegeven, hangt dat waarschijnlijk vooral samen met het negatieve beeld dat men heeft van de mogelijke milieuconsequenties. Voor alle onderscheiden technologieën wordt geconstateerd dat de waardering bij jongens significant hoger is dan bij meisjes. 
Figuur 4.4. De waardering van enkele technologische ontwikkelingen naar geslacht ${ }^{\mathrm{a}}$

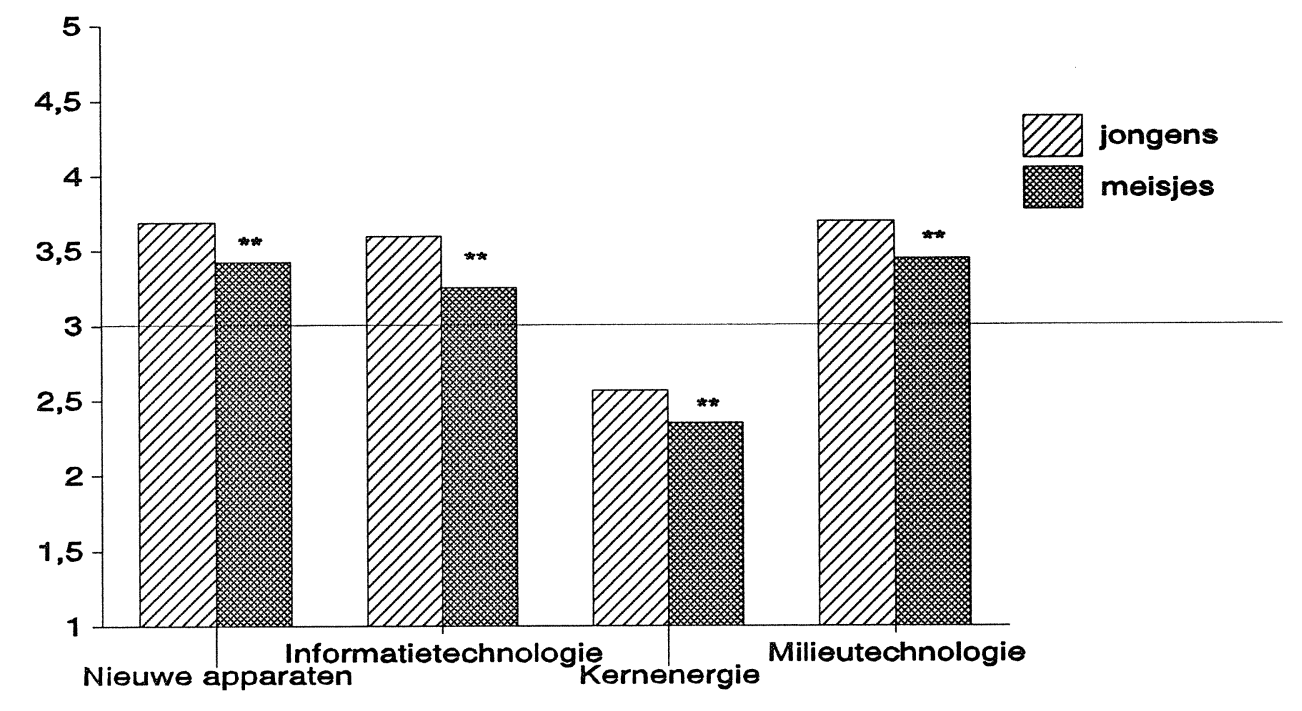

* = significant $5 \%$-niveau; ** = significant $1 \%$-niveau

a score groter dan 3 drukt positieve attitude uit

Wanneer een vergelijking wordt gemaakt van de bovenstaande resultaten met de resultaten zoals die voor de Nederlandse bevolking boven de 16 jaar zijn waargenomen (zie Knulst en Van Beek, 1988), dan blijken deze in grote mate overeen te komen ${ }^{14}$. Zowel kernenergie als milieutechnologie worden door de jongeren iets lager gewaardeerd dan door de rest van de bevolking. De tendenties zijn echter in beide onderzoeken hetzelfde. De waardering van informatietechnologie komt in beide onderzoeken vrijwel overeen. Uit deze resultaten zou men kunnen concluderen dat de houding van de Nederlanders ten opzichte van de verschillende vormen van technologische innovaties in de loop der jaren slechts weinig is veranderd. Bovendien betekent het feit dat ons onderzoek onder jongeren heeft plaatsgevonden dat wellicht ook op de wat langere termijn de houding van het gehele 'publiek' ten opzichte van technologische innovaties niet veel aan veranderingen onderhevig zal zijn.

14. Een vergelijking tussen jongeren en de overige bevolking van het algeheel oordeel over 'nieuwe apparaten' is niet mogelijk, omdat dit aspect niet in het onderzoek van Knulst en Van Beek is opgenomen. 


\section{DE WAARDERING VOOR TECHNIEK IN VOGELVLUCHT}

In dit tweede deel van het rapport is ingegaan op de waarde-oriëntatie ten aanzien van techniek. Eerst is daarbij de waardering van techniek in het algemeen aan de orde geweest. Daarna is nagegaan hoe de jongeren staan tegenover enkele specifieke technologieën.

Bij de beschrijving van de algemene waardering van techniek is een onderscheid gemaakt tussen drie elementen:

- interesse voor techniek;

- consequenties van techniek;

- meisjes en techniek.

Voor elk van deze elementen is met behulp van een aantal beweringen ('items'), waarbij de leerlingen hebben aangegeven in hoeverre zij het daarmee eens zijn, een techniekwaarderingsschaal geconstrueerd.

De interesse voor techniek blijkt bij jongens redelijk aanwezig te zijn. Meisjes zijn daarentegen in geringe mate in technische onderwerpen geïnteresseerd. Maar liefst meer dan de helft van alle meisjes heeft bij de enquête instemmend gereageerd op de stelling 'Techniek interesseert me niet', terwijl dit bij jongens nog geen $25 \%$ is. Voor alle opleidingscategorieën geldt dat jongens aan de positieve kant van de techniek-waarderingsscore zitten en meisjes aan de negatieve kant.

De VBO-Techniek-leerlingen zijn het meest in techniek geïnteresseerd, terwijl de leerlingen van het VBO-Overig de minste interesse tonen. Toch bestaat er met name bij de jongens van deze opleidingscategorie nog een redelijke interesse voor de technische richting. De beide in dit onderzoek onderscheiden AVO-opleidingscategorieën nemen op dit punt een tussenpositie in. Uit de uitgevoerde analyses is voorts gebleken dat de schoolprestaties (rapportcijfers) voor zowel de A- als de B-vakken significant samenhangen met de interesse van de leerlingen voor techniek: leerlingen met hoge cijfers voor de A-vakken zijn vaker minder in techniek geïnteresseerd, terwijl degenen die hoog scoren voor de B-vakken vaker een grotere interesse voor techniek vertonen. Verder blijkt er bij sommige opleidingscategorieën een samenhang te bestaan tussen de interesse voor techniek en de beroepsrichting van de ouders. Zo hebben de VBO-Techniek-leerlingen, waarvan de vader een technisch beroep heeft, meer interesse voor de techniek dan andere leerlingen van deze opleidingscategorie. De VBO-Techniek-leerlingen waarvan de moeder een medisch/verzorgend beroep uitoefent zijn daarentegen minder in techniek geïnteresseerd. Voor de leerlingen van het VBO-Overig blijkt dat degenen waarvan de moeder een economisch of een medisch/verzorgend beroep heeft minder interesse in techniek hebben. Hetzelfde beeld geldt voor de HAVO/VWO-leerlingen.

De mogelijke consequenties van technologische vernieuwing worden door de leerlingen in het algemeen vrij positief ingeschat. Ook hier blijkt echter weer dat meisjes een negatievere houding aannemen dan jongens. Vooral de gevolgen op het meer sociale vlak worden door meisjes negatiever beoordeeld. Al met al denken ook meisjes echter dat de positieve gevolgen van 
technologische vernieuwing de negatieve gevolgen overheersen.

De verschillen tussen de vier onderscheiden opleidingscategorieën met betrekking tot de houding ten opzichte van de consequenties van techniek zijn vrij gering. Wel blijkt dat de leerlingen van het HAVO/VWO waarvan de vader een technisch beroep heeft de gevolgen van de technologische ontwikkeling positiever inschatten.

Verder is aandacht besteed aan de houding ten opzichte van meisjes en techniek. Er blijken bij jongeren weinig twijfels meer te bestaan over de vraag of zowel jongens als meisjes in de techniek zouden moeten kunnen werken, hoewel jongens daar toch nog iets minder positief over denken dan meisjes. Het meest opvallend hierbij is echter dat de leerlingen afkomstig uit etnische minderheidsgroepen significant negatiever tegen de rol van meisjes in de techniek aankijken.

Vervolgens zijn, zoals gezegd, enkele specifieke technologieën op hun waardering door de leerlingen bekeken. Het gaat daarbij om de volgende vier kerntechnologieën:

- nieuwe apparaten;

- informatietechnologie;

- kernenergie;

- milieutechnologie.

Van deze vier technologieën worden nieuwe apparaten en milieutechnologie door de leerlingen al met al het hoogst gewaardeerd. Beide technologische ontwikkelingen scoren vrij hoog op de techniek-waarderingsschaal. Wel is het opmerkelijk dat meer dan de helft nog nooit van milieutechnologie heeft gehoord. Verder blijkt dat informatietechnologie eveneens op een vrij hoge waardering mag rekenen. Van de vier genoemde technologieën wordt alleen ten opzichte van kernenergie een negatieve houding aangenomen. Waarschijnlijk hangt dit samen met het feit dat veel jongeren vrezen voor het milieuvervuilende karakter van kernenergie.

Voor alle genoemde specifieke technologieën blijkt wederom dat jongens een hogere waardering hebben voor techniek dan meisjes. Verder is het opvallend dat de leerlingen van het HAVO/VWO het meest positief tegenover deze meer hoogwaardige technologieën staan. Bij de stellingen over techniek in het algemeen is immers de reactie van de VBO-Techniek-leerlingen het meest gunstig. Klaarblijkelijk bestaat er derhalve een eenzijdig beeld van wat 'techniek' inhoudt. Wellicht dat men bij techniek vaak denkt aan de elementen zoals die doorgaans in het voorbereidend of middelbaar technisch onderwijs aan de orde komen (bijvoorbeeld elektrotechniek, installatietechniek) en wordt techniek dus minder geassocieerd met de modernere technologische ontwikkelingen.

Concluderend kan men stellen dat het belang van technologische innovaties door de leerlingen wel in meerdere of mindere mate wordt ingezien. Een groot deel van de leerlingen is met name overtuigd van de economische voordelen die de technologische ontwikkeling biedt. De jongeren hebben echter wat meer twijfels over de overige maatschappelijke gevolgen van de techniek. 
Daarbij gaat het met name om het mogelijke milieuvervuilende aspect van de technologische ontwikkeling en het meer en meer ingewikkeld raken van de samenleving als gevolg van het introduceren van nieuwe technologische mogelijkheden.

Het grootste knelpunt bij de publiekshouding ten aanzien van techniek betreft echter de eigen interesse voor technische onderwerpen. Vooral meisjes geven aan dat 'de techniek' hen maar weinig interesseert. Opmerkelijk is echter dat de interesse voor de in dit deel besproken specifieke vormen van technologische ontwikkeling wel - ook bij meisjes - redelijk hoog is. Vooral 'nieuwe apparaten' worden door de leerlingen interessant gevonden. 



\section{DEEL III}

IMAGO VAN HET TECHNISCH ONDERWIJS 


\section{DE MOEILIJKHEIDSGRAAD VAN DE OPLEIDING}

\subsection{De bepaling van het relatieve imago van het technisch onderwijs}

In dit derde deel van het rapport zal worden nagegaan welk imago het technisch onderwijs onder de jongeren heeft. Dit imago wordt daarbij vanuit drie gezichtsvelden belicht. Eerst zal in dit hoofdstuk aandacht worden besteed aan het beeld dat de leerlingen hebben van de moeilijkheidsgraad van de verschillende opleidingsrichtingen. Vervolgens komt in hoofdstuk 7 aan de orde hoe de leerlingen de relatieve positie van verschillende onderwijsrichtingen op de arbeidsmarkt inschatten. Daarbij wordt zowel ingegaan op de kans op werk als op de verwachte inkomensverhoudingen. Hoofdstuk 8 beschrijft daarna de percepties van de jongeren met betrekking tot enkele kwalitatieve aspecten van het werk waarin men met de verschillende opleidingsrichtingen waarschijnlijk terecht komt. Op beide laatstgenoemde punten zal bovendien de beeldvorming worden vergeleken met meer feitelijke informatie hierover.

Voor het bepalen van het relatieve imago van het technisch onderwijs is aan de leerlingen gevraagd om verschillende opleidingsmogelijkheden op een aantal van de hierboven genoemde punten te rangschikken ${ }^{1}$. Daarbij kan men kiezen tussen enkele opleidingsrichtingen op het niveau dat direct aansluit op hun huidige opleidingsniveau. Voor de leerlingen van het VBO en het MAVO betekent dit dat zij een rangorde moeten aanbrengen tussen vier opleidingsrichtingen van het middelbaar beroepsonderwijs (MBO). De HAVO- en VWO-scholieren moeten respectievelijk zes opleidingsrichtingen van het hoger beroepsonderwijs ( $\mathrm{HBO}$ ) en zeven studierichtingen op universitair niveau rangschikken.

De plaats die het technisch onderwijs gemiddeld gezien in een bepaalde rangorde inneemt, wordt beschouwd als een indicatie voor het (relatieve) imago van het technisch onderwijs op het desbetreffende punt. Bovendien wordt op deze manier een beeld gekregen van de belangrijkste concurrenten van de technische richting op de verschillende opleidingsniveaus.

Met behulp van een eenvoudige formule ${ }^{2}$ wordt dit relatieve imago vervolgens uitgedrukt in een schaal van 0 tot 100 , waarbij een waarde van 0 een ten opzichte van de andere opleidingsrichtingen sterk negatief beeld van het technisch onderwijs weergeeft en een waarde van 100 een verhoudingsgewijs sterk positief beeld. De gebruikte indicator corrigeert enigszins voor het aantal vervolgopleidingen dat op een bepaald opleidingsniveau moet worden gerangschikt. Bij het vergelijken van het relatieve imago van het technisch onderwijs tussen de leerlingen van het

1. Een dergelijke methodiek is ook gevolgd door Kodde en Ritzen (1986).

2. $I=100-\frac{100}{n-1}(\bar{x}-1)$

waarbij: $I$ = indicator relatief imago technisch onderwijs;

$n=$ aantal onderscheiden opleidingsrichtingen (respectievelijk 4, 6 en 7 voor VBO en MAVO, HAVO en VWOI;

$\bar{x}=$ gemiddelde positie van het technisch onderwijs in de rangorde. 
VBO en het MAVO enerzijds en de leerlingen van het HAVO/VWO anderzijds moet er echter rekening mee worden gehouden dat de resultaten niet volledig vergelijkbaar zijn, aangezien de HAVO/VWO-leerlingen meer opleidingsrichtingen moeten rangschikken dan de VBO- en de MAVO-leerlingen. Overigens moet daarbij wel worden bedacht dat er op HBO- en WO-niveau ook daadwerkelijk meer keuzemogelijkheden zijn en dus ook de potentiële concurrentie van het technisch onderwijs groter is dan op MBO-niveau. De waarden van de imago-indicatoren voor het MAVO en de beide onderscheiden VBO-opleidingscategorieën kunnen wel direct met elkaar worden vergeleken.

\subsection{De moeilijkheidsgraad van de technische opleiding}

Het eerste element van het imago van het technisch onderwijs dat in dit deel van het rapport wordt geanalyseerd, betreft de gepercipieerde moeilijkheidsgraad van de opleiding. Eerst zal in deze paragraaf worden ingegaan op het beeld dat de leerlingen van de moeilijkheidsgraad van alle onderscheiden opleidingsrichtingen hebben. Vervolgens wordt specifiek aandacht besteed aan de positie van het technisch onderwijs op dit punt.

In de tabellen 6.1a. tot en met 6.1e., die zijn opgenomen in bijlage $D$ van dit rapport, is de gepercipieerde moeilijkheidsgraad van de onderscheiden opleidingsrichtingen weergegeven. Bijna de helft van alle leerlingen van het VBO-Techniek denkt dat het middelbaar economischadministratief onderwijs (MEAO) de moeilijkste van de onderscheiden vervolgrichtingen is. Ongeveer een kwart van de leerlingen denkt daarentegen dat het middelbaar technisch onderwijs (MTO) het moeilijkste is. Het middelbaar dienstverlenend en gezondheidszorgonderwijs (MDGO) en het middelbaar agrarisch onderwijs (MAO) behoren volgens de leerlingen tot de makkelijkere opleidingsrichtingen.

Ook de VBO-Overig-leerlingen verwachten dat het MEAO de moeilijkste vervolgopleiding is. Maar liefst $62 \%$ van de leerlingen is deze mening toegedaan. Bijna $20 \%$ van deze leerlingen denkt dat het MTO het moeilijkste is. Evenals de leerlingen van het VBO-Techniek rekenen de VBO-Overig-leerlingen het MDGO en het MAO tot de relatief makkelijke opleidingen.

Bij de MAVO-leerlingen bestaat eveneens het beeld dat het MEAO de moeilijkste vervolgopleiding is. Meer dan de helft van alle leerlingen denkt namelijk dat deze opleiding het moeilijkste is. Ook het MTO wordt door de MAVO-leerlingen tot de moeilijkere opleidingen gerekend. Bijna een kwart van alle leerlingen denkt dat dit de moeilijkste opleiding is. Het MDGO en het MAO zijn daarentegen volgens de MAVO-leerlingen relatief makkelijke opleidingsrichtingen.

Ruim $40 \%$ van de HAVO-leerlingen ${ }^{3}$ verwacht dat het hoger economisch-administratief

3. Aangezien de HAVO- en de VWO-leerlingen opleidingsrichtingen op een verschillend niveau hebben gerangschikt, worden de resultaten voor de opleidingscategorie HAVO/VWO hier voor de beide onderliggende opleidingstypen apart besproken. 
onderwijs (HEAO) de moeilijkste vervolgopleiding is. Het hoger technisch onderwijs (HTO) wordt door circa $35 \%$ van de HAVO-ers als de moeilijkste opleiding gezien. Het hoger pedagogisch onderwijs, het hoger agrarisch onderwijs en het hoger sociaal-cultureel onderwijs worden tot de makkelijkere opleidingsrichtingen gerekend, terwijl het hoger gezondheidszorgonderwijs op dit punt een middenpositie inneemt. Bij de VWO-leerlingen blijkt een enigszins afwijkend beeld. De VWO-leerlingen verwachten dat een studie in de medische wetenschappen het moeilijkste is. Daarnaast wordt een studie in de technische wetenschappen als een moeilijkere opleiding beschouwd. Ongeveer een derde van alle VWO-ers denkt dat dit de moeilijkste studie is. De studies letteren, sociale wetenschappen en vooral agrarische wetenschappen worden tot de relatief makkelijke opleidingen gerekend. Rechten en economie nemen een middenpositie in.

In figuur 6.1. is grafisch weergegeven wat het relatieve imago van het technisch onderwijs op het punt van de verwachte moeilijkheidsgraad van de opleiding is. Daarbij is een verschil gemaakt tussen het imago van het middelbaar technisch onderwijs, zoals dat wordt gezien door de leerlingen van het $\mathrm{VBO}$ en het MAVO, en het beeld van het hoger technisch onderwijs ${ }^{4}$, zoals de HAVO/VWO-leerlingen dat zien. Bovendien is in deze figuur een onderscheid gemaakt naar geslacht.

Figuur 6.1. Het relatieve imago van het technisch onderwijs met betrekking tot de moeilijkheidsgraad van de opleiding naar opleidingscategorie en geslacht

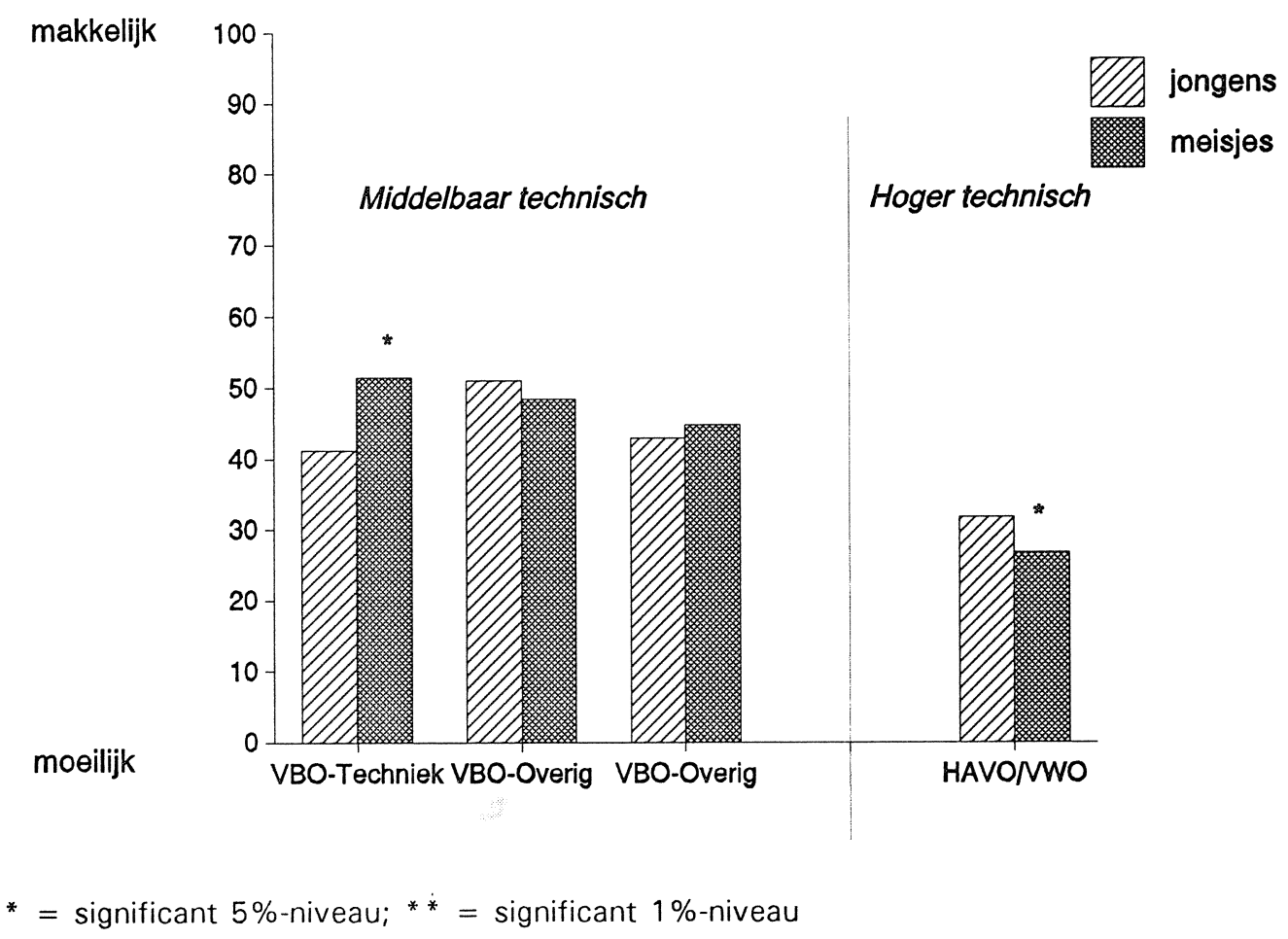

4. Hierbij wordt verder geen onderscheid gemaakt tussen technisch onderwijs op HBO- en WO-niveau. 
Tabel 6.2. Schattingsresultaten van een multivariate analyse van de gepercipieerde relatieve moeilijkheidsgraad van de technische opleiding naar opleidingscategorie (standaardfouten tussen haakjes)

\begin{tabular}{|c|c|c|c|c|c|c|c|c|}
\hline \multirow{2}{*}{$\begin{array}{l}\begin{array}{l}\text { Onafhankelijke } \\
\text { variabele }\end{array} \\
\text { constante }\end{array}$} & \multicolumn{2}{|c|}{ VBO-Techniek } & \multicolumn{2}{|c|}{ VBO-Overig } & \multicolumn{2}{|c|}{ MAVO } & \multicolumn{2}{|c|}{ HAVO/VWO } \\
\hline & $72,80^{* *}$ & $(13,93)$ & 20,76 & $(14,72)$ & 47,57 & $(27,24)$ & $85,37^{* *}$ & $(30,75)$ \\
\hline & $-0,68$ & $(5,89)$ & $-4,15$ & $(4,39)$ & 1,67 & $(4,61)$ & $-4,62$ & $(4,20)$ \\
\hline $\begin{array}{l}\text { etniciteit } \\
\text { rapportcijfers A-vakken }\end{array}$ & 8,26 & $(5,27)$ & $-24,38^{*}$ & $(5,52)$ & $-6,77$ & $(7,46)$ & $-4,99$ & $(7,69)$ \\
\hline $\begin{array}{l}\text { rapportcijfers A-vakken } \\
\text { rapportcijfers B-vakken }\end{array}$ & n.v.t. & & n.v.t. & & & $(3,09)$ & $-8,25^{*}$ & $(3,44)$ \\
\hline \multirow{2}{*}{\multicolumn{3}{|c|}{$\begin{array}{l}\text { Inschatting eigen capaciteiten } \\
\text { A-vakken }\end{array}$}} & n.v.t. & & $-1,14$ & $(2,73)$ & & \\
\hline & & & n.v.t. & & $-2,46$ & $(3,16)$ & 1,20 & $(3,18)$ \\
\hline \multirow{2}{*}{\multicolumn{9}{|c|}{$\begin{array}{l}\text { B-vakken } \\
\text { Regio }\end{array}$}} \\
\hline & & & & & & & & \\
\hline $\begin{array}{l}\text { noord } \\
\text { oost }\end{array}$ & $\begin{array}{r}4,29 \\
-0,19\end{array}$ & $\begin{array}{l}(5,10) \\
(5,05)\end{array}$ & $\begin{array}{r}4,76 \\
-1,01\end{array}$ & $\begin{array}{l}(7,17) \\
(5,16)\end{array}$ & $\begin{array}{r}8,09 \\
-4,45\end{array}$ & $\begin{array}{l}(8,81) \\
(5,48)\end{array}$ & $\begin{array}{r}7,87 \\
11,80^{*}\end{array}$ & $\begin{array}{l}(5,55) \\
(5,01)\end{array}$ \\
\hline $\begin{array}{l}\text { oost } \\
\text { west }\end{array}$ & \multicolumn{2}{|c|}{$\begin{array}{l}-0,19 \quad(5,0 b) \\
\text { referentie }\end{array}$} & \multicolumn{2}{|c|}{$\begin{array}{l}-1,01 \quad 13,1 \\
\text { referentie }\end{array}$} & \multicolumn{2}{|c|}{$\begin{array}{l}-4,45 \quad(0,40) \\
\text { referentie }\end{array}$} & \multicolumn{2}{|c|}{$\begin{array}{l}11,80 \quad(5,01) \\
\text { referentie }\end{array}$} \\
\hline zuid & $10,63^{* *}$ & $(4,03)$ & 3,70 & $(4,14)$ & $-3,18$ & $(4,39)$ & $-0,45$ & $(4,39)$ \\
\hline \multicolumn{7}{|l|}{ Typering van de leerling } & & \\
\hline $\begin{array}{l}\text { met mensen omgaan } \\
\text { carrière maken }\end{array}$ & $\begin{array}{l}-3,94 \\
-3,05\end{array}$ & $\begin{array}{l}(4,38) \\
(3,58)\end{array}$ & $\begin{array}{l}0,66 \\
7,91\end{array}$ & $\begin{array}{l}14,1 \\
14,6\end{array}$ & $\begin{array}{l}-2,82 \\
-1,90\end{array}$ & $\begin{array}{l}(4,90) \\
(4,95)\end{array}$ & $\begin{array}{l}0,52 \\
0,77\end{array}$ & $\begin{array}{l}(4,49) \\
(4,74)\end{array}$ \\
\hline nuttig werk doen & \multicolumn{2}{|c|}{ referentie } & \multicolumn{2}{|c|}{ referentie } & \multicolumn{2}{|c|}{$\begin{array}{l}-1,90 \text { referentie } \\
\text { res }\end{array}$} & \multicolumn{2}{|c|}{ referentie } \\
\hline \multicolumn{9}{|l|}{ Opleidingsniveau vader } \\
\hline Lager beroepsonderwijs & 7,81 & $(4,24)$ & 5,07 & $(5,14)$ & $-3,24$ & $(6,07)$ & 4,28 & $(5,80)$ \\
\hline Middelbaar beroepsonderwijs & $-9,47$ & $(6,74)$ & 4,17 & $(8,21)$ & $-5,34$ & $(7,8$ & 9,22 & $(7,14)$ \\
\hline derwijs & 4,59 & $(7,17)$ & $-1,74$ & $(10,10)$ & $-16,26^{*}$ & & 6,64 & $(4,79)$ \\
\hline anders/weet niet & $-3,65$ & $(4,96)$ & $-6,25$ & $(5,62)$ & $-7,69$ & $(5,59)$ & 6,79 & $(6,44)$ \\
\hline \multicolumn{3}{|l|}{$\begin{array}{l}\text { Opleidingsniveau moeder } \\
\text { Algemeen onderwijs }\end{array}$} & \multicolumn{2}{|c|}{ referentie } & \multicolumn{2}{|c|}{ referentie } & \multicolumn{2}{|c|}{ referentie } \\
\hline Lager beroepsonderwijs & 5,96 & $(4,07)$ & $-4,49$ & $(4,95)$ & 1,52 & $(4,82)$ & 1,71 & $(5,28)$ \\
\hline Middelbaar beroepsonderwijs & 10,87 & $(8,65)$ & 1,83 & $(8,58)$ & 12,17 & 16,7 & $-9,11$ & $(6,51)$ \\
\hline nderwijs & 22,54 & $(15,38)$ & $-16,60$ & 114,5 & $\begin{array}{l}6,53 \\
873\end{array}$ & $\begin{array}{r}(13,03) \\
(5,74)\end{array}$ & $\begin{array}{l}-3, \\
-4\end{array}$ & $\begin{array}{l}(5,78) \\
(6,94)\end{array}$ \\
\hline anders/weet niet & 6,77 & $(4,56)$ & & & & & & \\
\hline \multicolumn{9}{|l|}{ Beroepsrichting vader } \\
\hline $\begin{array}{l}\text { economisch } \\
\text { medisch/dienstverl./ }\end{array}$ & 2,97 & $(5,20)$ & 3,89 & $(5,10)$ & 3,27 & $(5,43)$ & $\begin{array}{l}0,00 \\
3,61\end{array}$ & $(4,74)$ \\
\hline \multirow{6}{*}{$\begin{array}{l}\text { medisch/dienstverl./ } \\
\text { verzorgend } \\
\text { overig } \\
\text { nooit beroep gehad/ } \\
\text { weet niet } \\
\text { Beroepsrichting moeder } \\
\text { technisch } \\
\text { economisch } \\
\text { medisch/dienstverl./ } \\
\text { verzorgend } \\
\text { overig } \\
\text { nooit beroep gehad/ } \\
\text { weet niet }\end{array}$} & $-0,81$ & $(6,73)$ & 12,18 & $(7,46)$ & 2,12 & $(7,73)$ & $-0,64$ & $(6,21)$ \\
\hline & refere & ntip & refere & & & & TEIEI & (tic \\
\hline & $-13,29$ & $(7,54)$ & 8,83 & $(8,07)$ & $-6,55$ & $(10,56)$ & 6,32 & $(12,19)$ \\
\hline & $\begin{array}{l}15,77 \\
-4,45\end{array}$ & $\begin{array}{r}(10,53) \\
(5,95)\end{array}$ & $\begin{array}{r}-13,05 \\
-8,15\end{array}$ & $\begin{array}{r}(11,13) \\
(7,10)\end{array}$ & $\begin{array}{r}10,06 \\
2,00\end{array}$ & $\begin{array}{r}(13,60) \\
(7,75)\end{array}$ & $\begin{array}{r}25,25 \\
4,15\end{array}$ & $\begin{array}{r}(15,81) \\
(5,15)\end{array}$ \\
\hline & $\begin{array}{l}-2,34 \\
\text { refere }\end{array}$ & entie & $\begin{array}{l}-7,65 \\
\text { refere }\end{array}$ & $n_{\text {ntie }}^{(6,11)}$ & $\begin{array}{l}6,17 \\
\text { refer }\end{array}$ & ntie $^{(7,51)}$ & $\begin{array}{l}7,39 \\
\text { refere }\end{array}$ & $e^{(5,24)}$ \\
\hline & $-2,40$ & $(5,79)$ & $-2,57$ & $(6,16)$ & 7,73 & $(8,14)$ & 6,08 & $(6,81)$ \\
\hline $\begin{array}{l}\text { interesse } \\
\text { consequenties }\end{array}$ & $\begin{array}{l}-2,75 \\
-6,38\end{array}$ & $\begin{array}{l}(2,50) \\
(3,26)\end{array}$ & $\begin{array}{l}-1,72 \\
10,25 *\end{array}$ & $\begin{array}{l}(2,38) \\
(3,66)\end{array}$ & $\begin{array}{r}-0,23 \\
0,81\end{array}$ & $\begin{array}{l}(2,33) \\
(3,96)\end{array}$ & $\begin{array}{l}2,73 \\
0,46\end{array}$ & $\begin{array}{l}(2,48) \\
(4,12)\end{array}$ \\
\hline $\begin{array}{l}n \\
R^{2}\end{array}$ & 451 & & 358 & & 316 & & 317 & \\
\hline $\mathrm{R}^{2}$ & 0,09 & & 0,13 & & 0,07 & & 0,15 & \\
\hline
\end{tabular}


Uit de figuur blijkt dat de leerlingen het technisch onderwijs tot de moeilijkere opleidingen rekenen. Vooral op het niveau van het hoger onderwijs schat men de technische richting als relatief moeilijk in. Daarbij zijn er weinig significante verschillen tussen jongens en meisjes. Wel is het opvallend dat de vrouwelijke VBO-Techniek-leerlingen de technische richting minder moeilijk inschatten dan hun mannelijke collega's op deze opleiding. Verder blijkt dat de meisjes van het HAVO/VWO het technisch onderwijs significant moeilijker inschatten dan jongens.

Met een eenvoudig multivariaat model wordt nagegaan of er belangrijke verklaringsgronden kunnen worden aangedragen voor het beeld, dat de leerlingen hebben van de relatieve moeilijkheidsgraad van de technische opleiding. De schattingsresultaten van dit model zijn weergegeven in tabel 6.2. Het blijkt dat de opgenomen onafhankelijke variabelen in het algemeen de gepercipieerde relatieve moeilijkheidsgraad van de opleiding slechts in zeer geringe mate verklaren.

De tabel laat zien dat er, in tegenstelling tot figuur 6.1., voor geen van de vier onderscheiden opleidingscategorieën sprake is van een significant verschil tussen jongens en meisjes op het punt van de verwachte moeilijkheidsgraad van het technisch onderwijs. Het meest opvallend bij het VBO-Overig is dat bij de leerlingen uit de etnische minderheidsgroepen het technisch onderwijs een veel negatiever imago heeft op dit punt. Voor het HAVO/VWO wordt een significante relatie met het gemiddelde rapportcijfer voor de A-vakken waargenomen: naarmate de leerlingen hoger scoren voor deze vakken, schatten zij de relatieve moeilijkheidsgraad van het hoger technisch onderwijs hoger in. Daarnaast denken de HAVO/VWO-leerlingen die zichzelf minder goed in de B-vakken vinden dat het technisch onderwijs in vergelijking met andere opleidingsrichtingen moeilijker is. Verder blijkt dat de VBO-Techniek-leerlingen in het zuiden van het land verwachten dat het technisch onderwijs minder moeilijk is.

Het opleidingsniveau en de beroepsrichting van de ouders blijken vrijwel niet samen te hangen met het beeld dat de leerlingen van de moeilijkheidsgraad van het technisch onderwijs hebben. Alleen de MAVO-leerlingen waarvan de vader een opleiding in het hoger onderwijs heeft gevolgd, blijken een vervolgopleiding in de technische richting significant vaker relatief moeilijk te vinden. Tenslotte schatten de VBO-Overig-leerlingen die positiever staan tegenover de mogelijke consequenties van de technologische ontwikkeling de moeilijkheidsgraad van de technische opleiding relatief hoger in. 


\section{ARBEIDSMARKTPOSITIE: WERK EN INKOMEN}

\subsection{Kans op werk}

In de tabellen 7.1a. tot en met 7.1e. (zie bijlage D) is een overzicht gegeven van de door de leerlingen verwachte kans op werk met de verschillende vervolgopleidingen. De VBO-Techniekleerlingen zien de beste arbeidsmarktkansen binnen hun eigen opleidingsrichting ${ }^{5}$. Maar liefst $70 \%$ van de VBO-Techniek-leerlingen denkt dat het MTO van de vier onderscheiden MBOopleidingsrichtingen de grootste kans op werk biedt. Het MEAO en het MDGO nemen achtereenvolgens de tweede en derde positie op de ranglijst van de vervolgopleidingen met de grootste kans op werk in. Het MAO wordt door het overgrote deel van de leerlingen gezien als een opleiding met een relatief slechte positie op de arbeidsmarkt.

De leerlingen van het VBO-Overig hebben het meest positieve beeld met betrekking tot de kans op werk voor de schoolverlaters van het MDGO en het MEAO. Klaarblijkelijk dicht men de vervolgopleidingen die aansluiten op de huidige opleiding de beste perspectieven op de arbeidsmarkt toe. Opvallend is dat het MTO slechts de derde positie op de ranglijst van opleidingen met de grootste kans op werk inneemt. Maar $15 \%$ van de leerlingen denkt dat men met deze opleiding de grootste kans op werk heeft. Het agrarisch onderwijs wordt wederom de slechtste kansen op de arbeidsmarkt toegedicht.

Verder blijkt dat de MAVO-leerlingen de kans op werk voor MEAO-schoolverlaters het hoogst inschatten. Ruim 40\% van de leerlingen denkt dat met deze opleiding de kans op werk het grootst is. Ongeveer een kwart van de leerlingen verwacht dat het MTO de beste kansen op de arbeidsmarkt biedt, terwijl een even groot deel van de MAVO-leerlingen het MDGO op dit punt het meest positief inschat. Het agrarisch onderwijs wordt ook door de MAVO-ers een relatief slechte positie op de arbeidsmarkt toegedicht.

De HAVO-leerlingen schatten de kans op werk het hoogste in voor het HTO en het HEAO. Meer dan de helft van alle HAVO-ers rekenen beide opleidingen tot de twee opleidingsrichtingen met de beste arbeidsmarktperspectieven. Het hoger gezondheidszorg- en het hoger pedagogisch onderwijs nemen qua verwacht arbeidsmarktperspectief een middenpositie in, terwijl het hoger sociaal-cultureel en met name het hoger agrarisch onderwijs een bij de leerlingen naar verwachting relatief slechte arbeidsmarktpositie hebben in vergelijking met de overige opleidingsrichtingen. Door de VWO-leerlingen worden de afgestudeerden in de technische wetenschappen de beste kansen op de arbeidsmarkt toegeschreven. Maar liefst $39 \%$ van de leerlingen denkt dat de afgestudeerden van een dergelijke studie de beste kans op werk hebben. Ook voor de afgestudeerden in de medische wetenschappen wordt een relatief gunstige positie op de arbeidsmarkt verwacht. In de door de leerlingen aangegeven rangorde met betrekking tot de kans op werk volgen daarna respectievelijk de studies economie, sociale wetenschappen en

5. Dit is vergelijkbaar met de resultaten van Stijnen en Wieling (1988), die vinden dat de leerlingen van het lager technisch onderwijs de kans op werk het hoogst inschatten voor hun eigen vakrichting. 
Oo

ML

het

nes

VB

$\mathrm{He1}$

ink

MA

not

Vel

ver

Oo

hor

op

gez

Res

opl

pes

ver

De

de

we

bes

eer

bes

tec

$\mathrm{On}$

hor

lett

Fig

het

dat

ink

jon

rechten. Voor de studies letteren en agrarische wetenschappen wordt de relatief kleinstı op werk verwacht.

Uit figuur 7.1. blijkt dat het imago van het technisch onderwijs met betrekking tot de $\mathbf{k}$ werk vooral bij jongens relatief hoog is. Voor alle vier de onderscheiden opleidingscates wordt echter geconstateerd dat het beeld van de relatieve arbeidsmarktpositie van het tec onderwijs bij meisjes significant negatiever is. Vooral de meisjes van het VBO-Overig MAVO schatten de kans op werk voor middelbaar technisch opgeleiden relatief laag in. laat de figuur zien dat onder de leerlingen van het VBO-Techniek en het HAVO/VWO het gunstige beeld van de technische opleiding op dit punt bestaat.

Figuur 7.1. Het relatieve imago van het technisch onderwijs met betrekking tot de kans op wt opleidingscategorie en geslacht

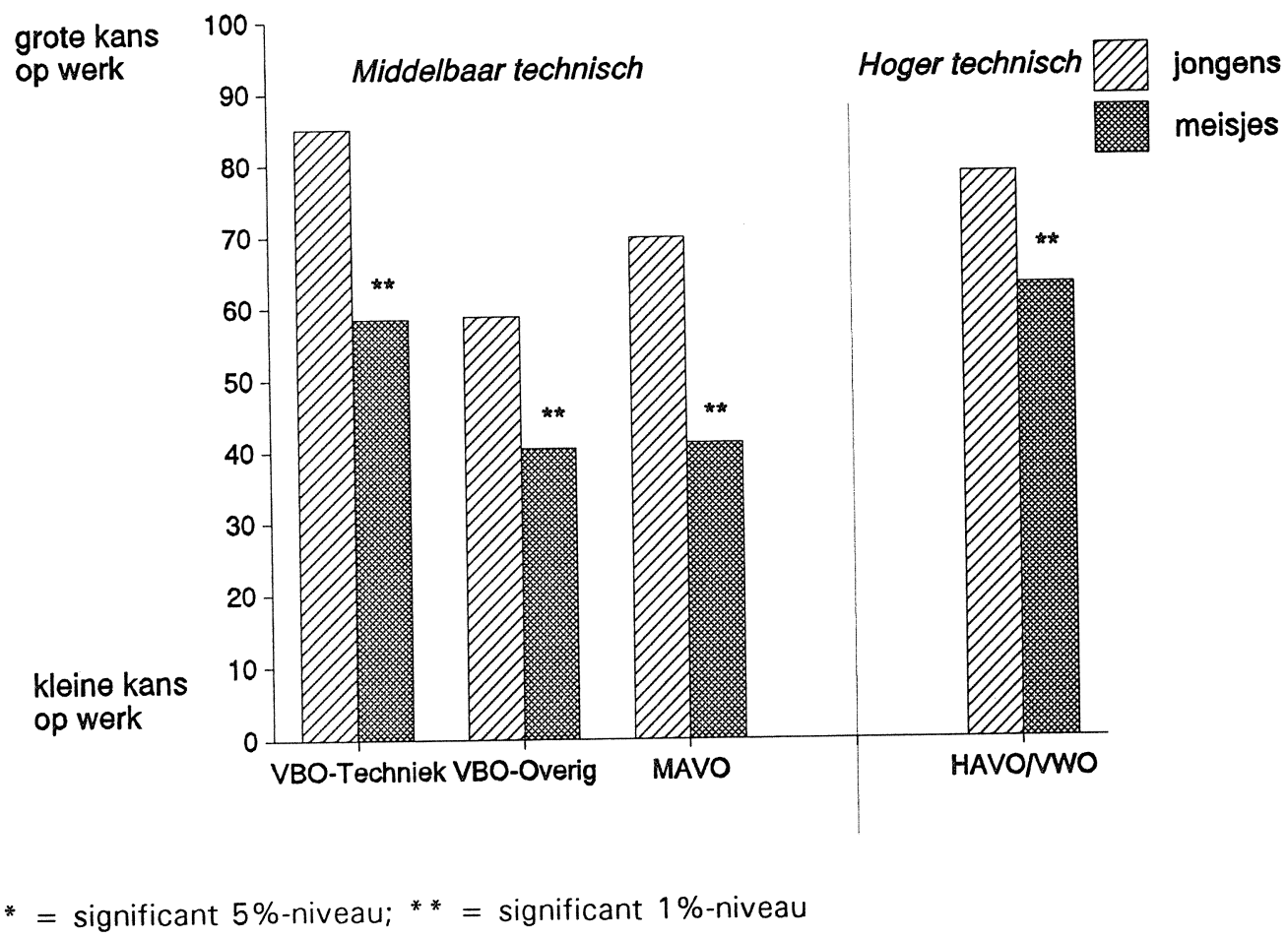

Het hierboven gepresenteerde beeld dat de leerlingen hebben van de kans op werk verschillende mogelijke vervolgopleidingen kan worden vergeleken met de beschikba feitelijke gegevens hierover. Door deze confrontatie van de percepties van de leerlinger daadwerkelijke situatie kan een beeld worden verkregen van mogelijke misverstanden $c$ de Nederlandse jongeren heersen met betrekking tot de arbeidsmarktpositie van het tı onderwijs.

Voor de vergelijking met de actuele arbeidsmarktsituatie worden de volgende $\subseteq$ 
geeft het Centraal Bureau voor de Statistiek (1987) enig inzicht in de relatieve inkomenspositie van middelbaar technisch opgeleiden.

In het algemeen blijken de leerlingen de bestaande inkomensverhoudingen tussen de opleidingen redelijk goed in te schatten. Een belangrijk verschilpunt tussen het beeld dat de leerlingen hebben en de daadwerkelijke inkomenssituatie is echter de positie van het economisch onderwijs. De leerlingen denken dat met een dergelijke opleiding het hoogste inkomen kan worden bereikt, maar dit strookt niet met de situatie zoals die momenteel - gemiddeld gezien voor de schoolverlaters geldt. Door dit waarschijnlijk onterecht te gunstige imago van het economisch onderwijs wordt vooral de relatieve positie van het technisch onderwijs te laag ingeschat.

Tenslotte lijkt ook het minder positieve beeld dat meisjes van de verdiensten van technisch opgeleiden hebben ongegrond. Op basis van de RUBS-enquête blijkt dat de inkomens van vrouwelijke technisch opgeleiden hoger zijn dan de inkomens van vrouwelijke schoolverlaters van de andere opleidingsrichtingen. Verder kan worden opgemerkt dat terwijl op MBO-niveau de salarissen van vrouwen gemiddeld duidelijk lager zijn dan die van mannen, de schoolverlaters van het MTO hierop een uitzondering vormen. Bij dit opleidingstype wordt vrijwel geen verschil in gemiddeld inkomen geconstateerd. Overigens is het niet uitgesloten dat in de loop van de carrière grotere inkomensverschillen tussen mannen en vrouwen ontstaan.

\subsection{De arbeidsmarktpositie van het technisch onderwijs}

In deze paragraaf zal worden ingegaan op mogelijke determinanten van het beeld dat de leerlingen hebben van de arbeidsmarktpositie van het technisch onderwijs. Daarbij zal geen onderscheid worden gemaakt tussen de beide aspecten van de relatieve arbeidsmarktpositie (kans op werk en kans op een hoog inkomen) ${ }^{7}$. In tabel 7.3. worden de schattingsresultaten van de multivariate analyse gepresenteerd. Duidelijk blijkt dat het relatieve imago van het technisch onderwijs op het gebied van de verwachte arbeidsmarktpositie van de afgestudeerden bij meisjes ongunstiger is dan bij jongens. Alleen bij het VBO-Overig is het verschil tussen jongens en meisjes op dit punt niet significant. Voor het MAVO wordt verder een significant positieve invloed van de rapportcijfers voor de B-vakken op het relatieve imago van het technisch onderwijs geconstateerd.

Evenals ten aanzien van de verwachte moeilijkheidsgraad van het technisch onderwijs, blijkt ook op het punt van de verwachte arbeidsmarktpositie van technisch opgeleiden dat het opleidingsniveau en de beroepsrichting van de ouders hierop vrijwel geen invloed hebben. Wel hebben de VBO-Techniek-leerlingen waarvan de moeder een opleiding in het lager beroepsonderwijs heeft gevolgd, een negatiever beeld van de arbeidsmarktpositie van technisch opgeleiden. Ook VBO-Overig-leerlingen waarvan de moeder een medisch/dienstverlenend beroep

7. De indicator voor de verwachte relatieve arbeidsmarktpositie van het technisch onderwijs is bepaald als het ongewogen gemiddelde van beide onderliggende indicatoren. 
Tabel 7.3. Schattingsresultaten van een multivariate analyse van de gepercipieerde relatieve arbeidsmarktpositie van technisch opgeleiden naar opleidingscategorie (standaardfouten tussen haakjes)

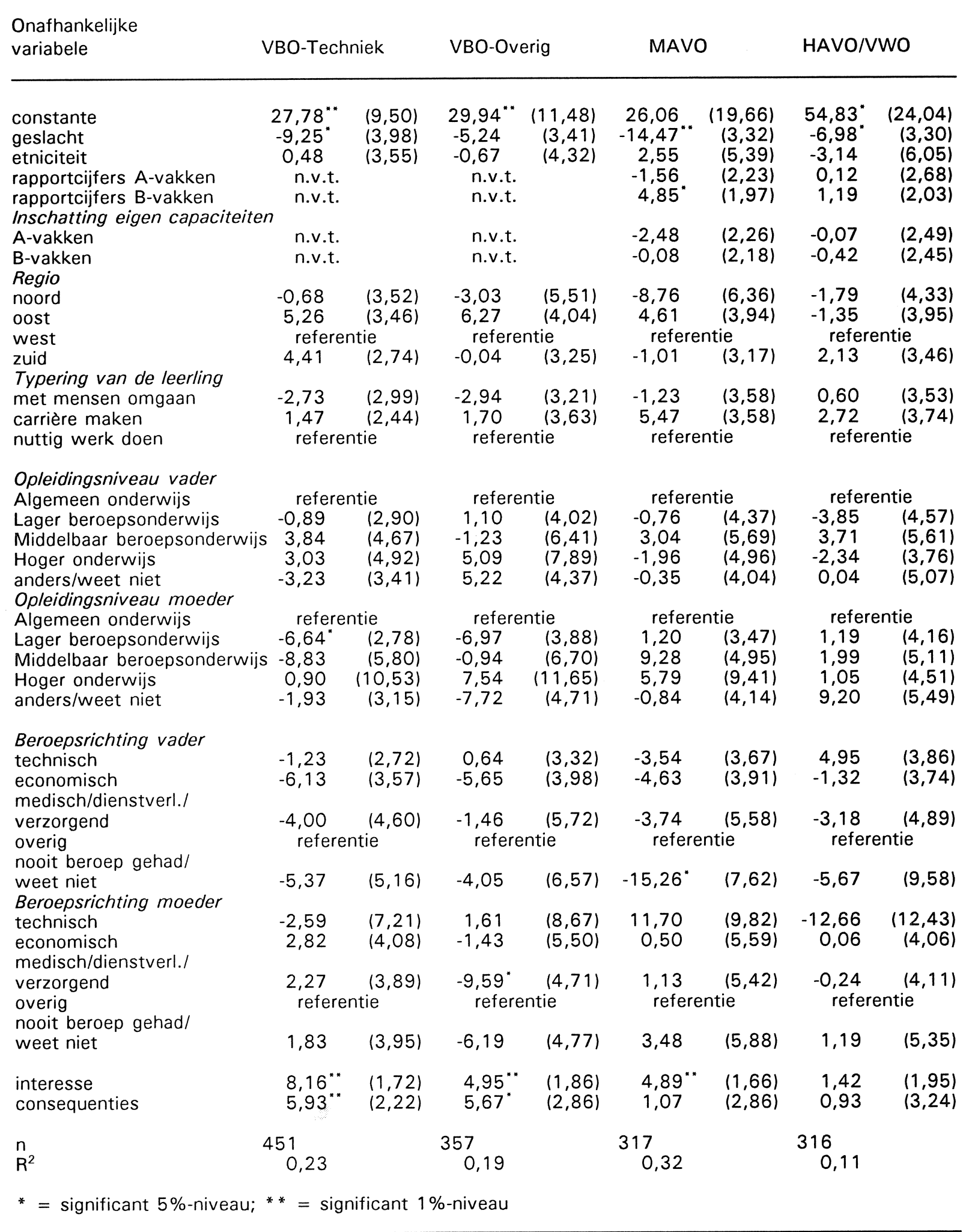


heeft, schatten de kans op de arbeidsmarkt voor technisch opgeleiden verhoudingsgewijs lager in.

Tenslotte laat de tabel zien dat er een duidelijk positieve relatie is tussen de verwachte arbeidsmarktpositie van technisch opgeleiden en de interesse van de leerlingen in techniek. Alleen bij het HAVO/VWO is het verschil niet significant. Verder blijkt dat de VBO-leerlingen die een positievere houding aannemen ten opzichte van de mogelijke gevolgen van de technologische ontwikkeling ook de arbeidsmarktpositie van technisch opgeleiden positiever inschatten. 


\section{KWALITATIEVE ASPECTEN VAN HET WERK}

\subsection{Zwaar werk}

De tabellen 8.1a. tot en met 8.1e. van bijlage $\mathrm{D}$ bij dit rapport geven een beeld van de door de leerlingen verwachte kans op lichamelijk zwaar werk, indien voor een bepaalde vervolgopleiding wordt gekozen. Maar liefst $40 \%$ van de VBO-Techniek-leerlingen is van mening dat MTOopgeleiden het vaakst zwaar werk moeten verrichten. Ook agrarisch opgeleiden wordt door deze leerlingen een fysiek zware baan toegedicht. Daarentegen wordt voor de schoolverlaters van het MDGO en het MEAO de kans op zwaar werk relatief klein geacht.

Een geheel ander beeld wordt waargenomen onder de VBO-Overig-leerlingen. Zij denken dat de MDGO-opgeleiden de grootste kans op zwaar werk hebben. Ruim een kwart van de leerlingen denkt daarentegen dat het MTO de opleidingsrichting is waarmee men vaak zwaar werk moet doen. Een ongeveer even groot deel van de leerlingen denkt dat het MAO dit is. De VBO-Overigleerlingen zijn van mening dat de kans op zwaar werk met een MEAO-opleiding verhoudingsgewijs gering is. Maar liefst $75 \%$ van de leerlingen is deze mening toegedaan.

De MAVO-leerlingen denken dat men met middelbaar agrarisch onderwijs de grootste kans op lichamelijk zwaar werk heeft. Daarna wordt aan de schoolverlaters van respectievelijk het MDGO en het MTO de meest zware baan toegedicht. Voor beide opleidingsrichtingen blijkt dat ongeveer een kwart van de MAVO-ers verwacht dat de opgeleiden het vaakst zwaar werk hebben. Ook door de leerlingen van het MAVO wordt verwacht dat MEAO-ers de kleinste kans op een fysiek zware baan hebben.

Het merendeel van HAVO-leerlingen schat de kans op zwaar werk het hoogste in voor de afgestudeerden van het hoger agrarisch onderwijs. Een veel geringer deel van de leerlingen denkt dat de afgestudeerden van het hoger gezondheidszorgonderwijs en het hoger technisch onderwijs relatief vaak een lichamelijk zware baan hebben. Het hoger sociaal-cultureel, het hoger pedagogisch en vooral het hoger economisch onderwijs hebben bij de HAVO-leerlingen het imago van opleidingen waarmee men niet vaak een lichamelijk zware baan zal krijgen.

Volgens de VWO-leerlingen hebben de afgestudeerden van de agrarische wetenschappen de grootste kans om in een lichamelijk zware baan terecht te komen, op enige afstand gevolgd door degenen met een studie in de medische wetenschappen. Met een studie letteren, economie of rechten wordt de kans op zwaar werk daarentegen erg klein geacht, terwijl sociale wetenschappen en technische wetenschappen op dit punt een middenpositie innemen.

In figuur 8.1. is de relatieve positie van het technisch onderwijs op het punt van de verwachte kans op lichamelijk zwaar werk grafisch weergegeven, waarbij een verbijzondering is gemaakt naar opleidingscategorie en geslacht. Bij alle opleidingscategorieën blijkt dat het technisch onderwijs wordt gerekend tot de opleidingen waarmee men in verhouding tot de andere opleidingsrichtingen een grote kans loopt om in een lichamelijk zwaar beroep terecht te komen. 
Opvallend daarbij is dat dit beeld van het werkveld bij de leerlingen van het VBO-Techniek het meest extreem is. Alleen bij de MAVO-leerlingen wordt op dit punt een significant verschil tussen jongens en meisjes geconstateerd: de jongens die op het MAVO zitten hebben een negatiever beeld van het technisch onderwijs dan de meisjes. In het algemeen kan worden opgemerkt dat met name het economisch onderwijs op dit punt in de ogen van de leerlingen een veel aantrekkelijker perspectief biedt dan het technisch onderwijs.

Figuur 8.1. Het relatieve imago van het technisch onderwijs met betrekking tot de kans op een lichamelijk zwaar beroep naar opleidingscategorie en geslacht

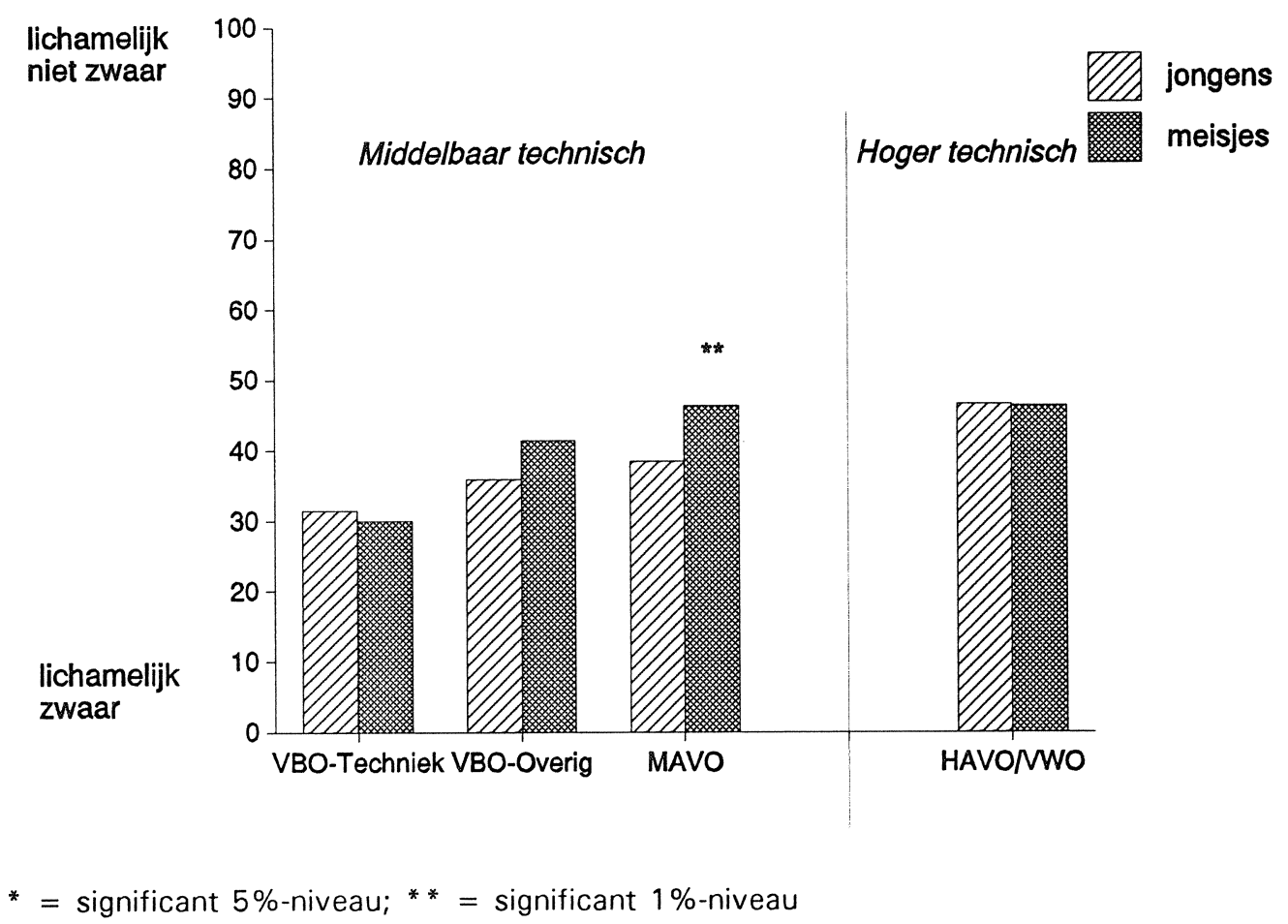

Het beeld dat de leerlingen hebben van de kwaliteit van het werk van technisch opgeleiden kan eveneens worden vergeleken met meer feitelijke informatie. Daarbij wordt gebruik gemaakt van de gegevens van de vijfde golf van het arbeidsaanbodpanel van de Organisatie voor Strategisch Arbeidsmarktonderzoek (OSA), die is gehouden in het najaar van 1992 (zie Allaart, Kunnen, Praat, De Voogd-Hamelink en Vosse, 1993). In tabel 8.2. is weergegeven welk percentage van de arbeidskrachten met een bepaalde opleidingsachtergrond regelmatig zwaar werk moet doen. Daarbij is een onderscheid gemaakt naar de verschillende opleidingsrichtingen op MBO- en op hoger niveau. Vanwege de te geringe celvulling voor HBO- en WO-opgeleiden bij de OSA-data is het helaas niet mogelijk om deze twee opleidingsniveaus afzonderlijk in beeld te brengen.

De vergelijking van de verwachtingen van de leerlingen met de meer feitelijke informatie over de lichamelijke zwaarte van het werk levert een opvallend beeld op. In tegenstelling tot hetgeen de 
leerlingen denken, blijkt uit de OSA-gegevens dat technisch opgeleiden in verhouding tot de andere opleidingscategorieën niet vaak lichamelijk zwaar werk doen. Vooral op hoger niveau heeft slechts een zeer klein deel van de werkende technisch opgeleiden lichamelijk zwaar werk. Bij de middelbaar technisch opgeleiden is dit aandeel aanmerkelijk groter, maar duidelijk lager dan bij degenen met een MAO- of MDGO-opleiding.

Tabel 8.2. Aandeel werkenden dat aangeeft dat lichamelijk zwaar werk hoofdzakelijk tot hun werk behoort naar opleidingsniveau en -richting

Opleiding

lichamelijk

zwaar werk

$\%$

Middelbaar agrarisch onderwijs

50

Middelbaar technisch onderwijs

Middelbaar economisch-administratief onderwijs

37

Middelbaar dienstverlenend/gezondheidszorg onderwijs

16

52

Hoger onderwijs: pedagogisch/letteren

5

Hoger onderwijs: agrarisch

15

Hoger onderwijs: technisch

4

Hoger onderwijs: economisch/juridisch

Hoger onderwijs: gezondheidszorg/medisch

Bron: OSA

\subsection{Stress}

Terwijl de VBO-Techniek-leerlingen denken dat MTO-opgeleiden relatief vaak een fysiek zware baan hebben, verwacht men voor de schoolverlaters van het MEAO een relatief grote kans op een psychisch zwaar beroep (zie de tabellen 8.3a. tot en met 8.3e. van bijlage D). Bijna de helft van de leerlingen acht de kans op een beroep met veel stress het grootste voor deze opleidingscategorie. Ook van het MDGO heeft men op dit punt een vrij negatief beeld. De leerlingen van het VBO-Techniek denken dat met een MTO- of een MAO-opleiding de kans op een beroep met veel stress relatief klein is.

Bij de leerlingen van het VBO-Overig blijkt een soortgelijk beeld te bestaan. Ook van deze leerlingen verwacht ongeveer de helft dat de schoolverlaters van het MEAO de grootste kans hebben om in een beroep met veel stress terecht te komen. De relatieve positie van het MTO en het MAO op dit punt wordt door de VBO-Overig-leerlingen, evenals bij de VBO-Techniekleerlingen het geval is, gunstig ingeschat.

De percepties van de MAVO-leerlingen op het punt van de verwachte kans op een beroep met veel stress zijn nog extremer. Meer dan de helft van alle MAVO-ers denkt dat de toekomstige banen van MEAO-ers psychisch het meest zwaar belastend zijn. Slechts ongeveer $5 \%$ van de MAVO-leerlingen acht de kans op stress het grootst voor schoolverlaters van het MTO. Meer 
dan een kwart van de leerlingen denkt daarentegen dat deze schoolverlaters de kleinste kans op een psychisch zwaar beroep hebben.

Bij de HAVO-leerlingen wordt niet het hoger economisch onderwijs, maar het hoger pedagogisch onderwijs gezien als een opleiding waarvan de afgestudeerden in hun werk relatief vaak met stress te maken krijgen. Ook voor de afgestudeerden van het hoger sociaal-cultureel onderwijs wordt een relatief grote kans op stress verwacht. Voor het hoger gezondheidszorgonderwijs, het hoger technisch onderwijs en het hoger agrarisch onderwijs is de verwachte kans op een beroep met veel stress verhoudingsgewijs klein.

De VWO-leerlingen denken dat de afgestudeerden in de medische wetenschappen en in de rechten het vaakst een stressvolle baan hebben. Ook voor degenen die een studie in de sociale wetenschappen en, zij het in iets mindere mate, voor degenen die een economiestudie hebben afgerond wordt de kans op stress vrij groot geacht. Volgens de VWO-ers hebben de afgestudeerden in de agrarische wetenschappen, letteren en technische wetenschappen in hun werk in verhouding tot de afgestudeerden van de andere opleidingsrichtingen weinig met stress te kampen.

Figuur 8.2. Het relatieve imago van het technisch onderwijs met betrekking tot de kans op een beroep met veel stress naar opleidingscategorie en geslacht

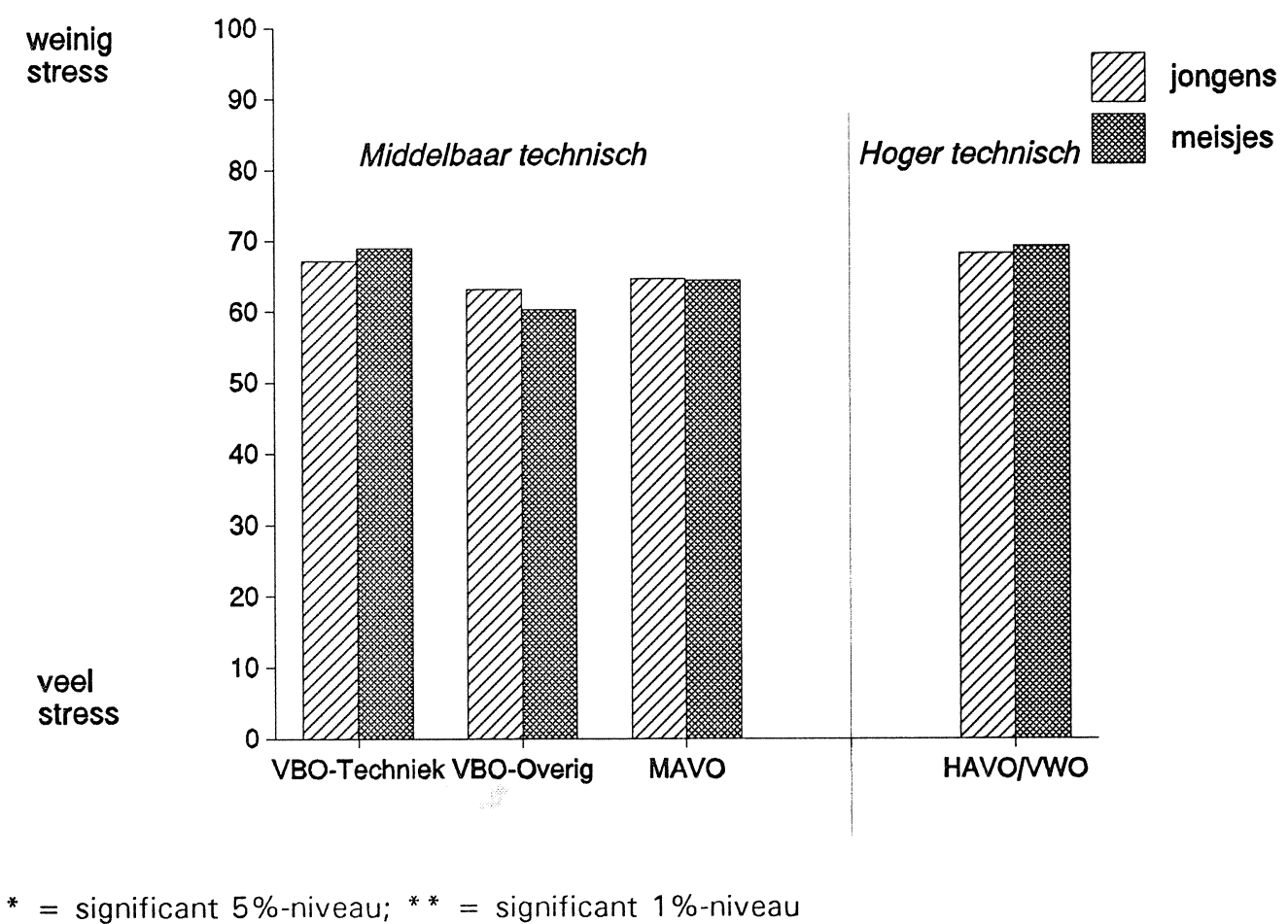


Ook voor dit aspect van de kwaliteit het werkveld van technisch opgeleiden is een grafische weergave gemaakt. Uit figuur 8.2. kan worden geconcludeerd dat het imago van het technisch onderwijs op het punt van de verwachte kans op een beroep met veel stress vrij gunstig is. Dit geldt voor alle vier onderscheiden opleidingscategorieën. Bovendien zijn er op dit punt geen significante verschillen tussen jongens en meisjes. Het OSA-arbeidsaanbodpanel bevat helaas geen gegevens over de mate van stress in het werk, zodat op dit punt geen vergelijking met meer feitelijke informatie wordt gemaakt.

\subsection{Vuil werk}

Als derde kwalitatieve aspect van het werkveld van technisch opgeleiden in vergelijking met de werkvelden van andere opleidingsrichtingen komt in deze paragraaf de kans op vuil werk aan de orde. In bijlage $D$ is in de tabellen 8.4a. tot en met 8.4e. een overzicht opgenomen van de verwachtingen van de leerlingen ten aanzien van de kans dat men met een bepaalde vervolgopleiding in een beroep terecht komt, waarbij men vaak vuil werk moet doen. De leerlingen van het VBO-Techniek achten deze kans het kleinst voor MEAO-opgeleiden. Maar liefst ruim $70 \%$ van de leerlingen is deze mening toegedaan. Daarna wordt voor de schoolverlaters van het MDGO de kleinste kans op vuil werk verwacht. Daarentegen wordt gedacht dat MTO- en MAO-opgeleiden relatief vaak in beroepen terecht komen waarin men dikwijls vuil werk moet doen.

Eenzelfde beeld blijkt er bij de leerlingen van het VBO-Overig te bestaan. Ook zij verwachten voor MEAO-ers de kleinste kans op vuil werk, terwijl de verwachting is dat MTO- en vooral MAO-schoolverlaters in verhouding tot de andere opleidingsrichtingen vaak vuil werk moeten doen. Een dergelijke beeldvorming op dit punt is er eveneens bij de leerlingen van het MAVO. Zij positioneren de onderscheiden opleidingsrichtingen op dezelfde manier ten opzichte van elkaar.

De leerlingen van het HAVO verwachten ook dat de economische richting de beste vooruitzichten heeft wat betreft het krijgen van een baan waarbij men niet vaak vuil werk hoeft te doen. Ruim $60 \%$ van de HAVO-leerlingen denkt dat de kans op vuil werk het kleinst is voor afgestudeerden van het hoger economisch onderwijs. Ook voor het hoger pedagogisch onderwijs is het beeld op dit punt relatief gunstig. Daarentegen schat bijna $70 \%$ van de leerlingen de kans op vuil werk het grootste in voor de afgestudeerden van het hoger agrarisch onderwijs. Het hoger technisch onderwijs wordt eveneens tot de opleidingsrichtingen gerekend waarbij men vaak vuil werk moet doen. Het hoger sociaal-cultureel onderwijs en het hoger gezondheidszorgonderwijs nemen tenslotte een middenpositie in.

Bij de VWO-leerlingen is de verwachting dat de afgestudeerden in de letteren, rechten of economie het minst vaak met vuil werk in aanraking komen. Deze leerlingen schatten de kans op vuil werk het grootste in voor de afgestudeerden in de agrarische wetenschappen en in de medische wetenschappen. Volgens de VWO-leerlingen is voor de afgestudeerden in de technische wetenschappen of sociale wetenschappen de kans op vuil werk niet uitgesproken groot of klein. 
Uit de samenvattende figuur 8.3. komt naar voren dat het technisch onderwijs door de leerlingen tot de opleidingen wordt gerekend, waarmee de kans op vuil werk groter is dan gemiddeld. Opvallend daarbij is dat de meisjes van de opleidingscategorieën HAVO/VWO en VBO-Overig op dit punt een negatiever beeld hebben dan de jongens van de desbetreffende opleidingen. Verder is het opmerkelijk dat het relatieve imago van het technisch onderwijs wat betreft de kans op vuil werk het meest negatief is bij de leerlingen van het VBO-Techniek. Een soortgelijk resultaat is eerder ook geconstateerd ten aanzien van de kans op een lichamelijk zwaar beroep.

Figuur 8.3. Het relatieve imago van het technisch onderwijs met betrekking tot de kans op een beroep met vaak vuil werk naar opleidingscategorie en geslacht

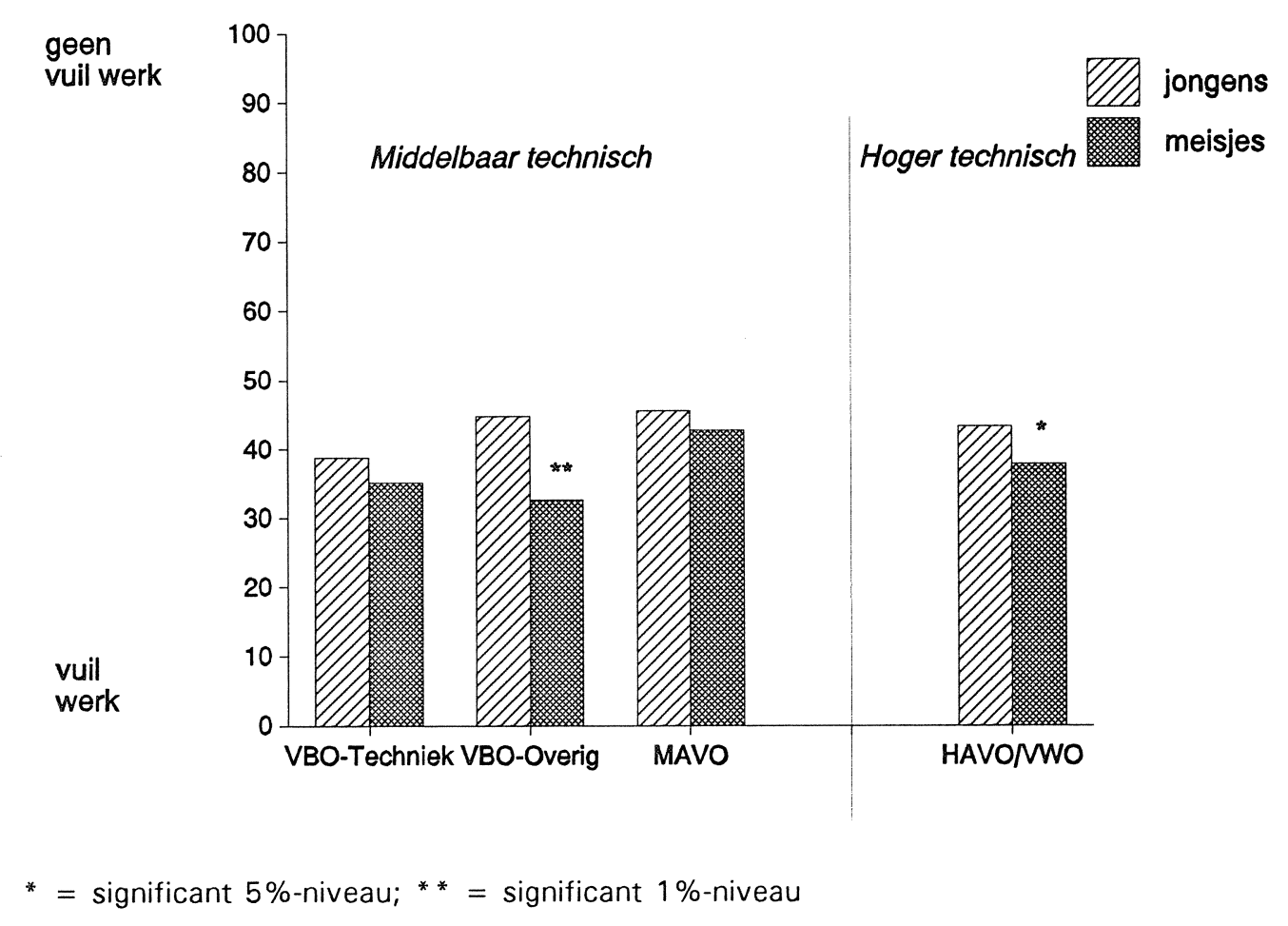

In tabel 8.5. is aangegeven welk deel van de werkenden, verbijzonderd naar opleidingsniveau en -richting, daadwerkelijk regelmatig vuil werk $^{8}$ moet verrichten. Op MBO-niveau neemt de technische richting van de vier onderscheiden richtingen de tweede plaats in op de lijst van opleidingen met regelmatig vuil werk. De technisch opgeleiden op HBO- en WO-niveau hebben in hun werk echter nauwelijks met vuil werk te maken. Slechts $4 \%$ van de arbeidskrachten geeft aan dat vuil werk een substantieel deel uitmaakt van hun dagelijkse werkzaamheden. Veel leerlingen hebben derhalve een te negatief beeld van het werk van hoger technisch opgeleiden

8. In de OSA-vragenlijst wordt overigens geen onderscheid gemaakt tussen vuil werk en werk bij hoge temperaturen. 
op dit punt. Met name het werk van medisch opgeleiden wordt daarentegen door de leerlingen te positief ingeschat.

Tabel 8.5. Aandeel werkenden dat aangeeft dat vuil werk hoofdzakelijk tot hun werk behoort naar opleidingsniveau en -richting

Opleiding

vuil werk

$\%$

Middelbaar agrarisch onderwijs 39

Middelbaar technisch onderwijs

31

Middelbaar economisch-administratief onderwijs

Middelbaar dienstverlenend/gezondheidszorg onderwijs

Hoger onderwijs: pedagogisch/letteren

Hoger onderwijs: agrarisch $\quad 23$

Hoger onderwijs: technisch 4

Hoger onderwijs: economisch/juridisch

Hoger onderwijs: sociaal-cultureel 1

Hoger onderwijs: gezondheidszorg/medisch 8

Bron: OSA

\subsection{Saai werk}

Ruim $60 \%$ van de VBO-Techniek-leerlingen denkt dat het werk van MEAO-opgeleiden saai is. (zie de tabellen 8.6a. tot en met 8.6e. van bijlage D). Ook voor de schoolverlaters van het MDGO wordt door VBO-Techniek-leerlingen een vrij saai beroepsperspectief verwacht, terwijl bovendien het relatieve imago van het middelbaar agrarisch onderwijs op dit punt niet erg gunstig is. Het merendeel van de VBO-Techniek-leerlingen blijkt van mening te zijn dat men met een MTO-opleiding in beroepen terecht komt waarbij de kans op saai werk het kleinst is. Bijna $60 \%$ van de leerlingen is deze mening toegedaan.

Ook de leerlingen van het VBO-Overig denken dat MEAO-ers de grootste kans hebben om in beroepen terecht te komen die saai zijn. Voor de schoolverlaters van het MDGO wordt de kleinste kans op saai werk verwacht. Bij het VBO-Overig nemen het agrarisch en het technisch onderwijs een middenpositie in. De MAVO-leerlingen verwachten eveneens dat het werk van MEAO-opgeleiden in verhouding tot de andere opleidingscategorieën saai is. Het beeld dat de MAVO-ers van de drie andere onderscheiden opleidingsrichtingen hebben ontloopt elkaar niet zo veel.

De leerlingen van het HAVO hebben een vergelijkbaar beeld van de verschillende opleidingsrichtingen wat betreft de kans op saai werk. Ongeveer de helft van de leerlingen verwacht dat de afgestudeerden van het hoger economisch onderwijs het vaakst in beroepen terecht komen waar je vaak saai werk moet doen. Degenen die hoger gezondheidszorgonderwijs hebben gevolgd, hebben volgens de HAVO-ers de kleinste kans op saai werk. De VWO-leerlingen denken dat de afgestudeerden in de letteren de meeste kans op een saaie baan hebben. Ook de 
afgestudeerden in de economie en de rechten hebben naar verwachting in verhouding tot de andere studierichtingen vaak een beroep dat saai is. Voor degenen die een studie in de medische wetenschappen hebben afgerond wordt de kleinste kans op saai werk verwacht.

Figuur 8.4. toont een grafische weergave van het relatieve imago van het technisch onderwijs met betrekking tot de verwachte kans op saai werk, verbijzonderd naar opleidingscategorie en geslacht. Opvallend is dat de meisjes van alle vier de onderscheiden opleidingscategorieën significant vaker dan jongens het werk van technisch opgeleiden met saai werk associëren. Terwijl de jongens in het algemeen de kans op saai werk voor technisch opgeleiden als relatief klein inschatten, bestaat bij de meisjes een veel negatiever beeld. Dit zal waarschijnlijk samenhangen met het feit dat meisjes techniek ook minder interessant vinden dan jongens (zie deel II van dit rapport). Verder kan worden opgemerkt dat de leerlingen van het VBO-Techniek het meest gunstige beeld hebben van het werk van technisch opgeleiden op het vlak van de kans dat men vaak saai werk moet doen.

Figuur 8.4. Het relatieve imago van het technisch onderwijs met betrekking tot de kans op een beroep met vaak saai werk naar opleidingscategorie en geslacht

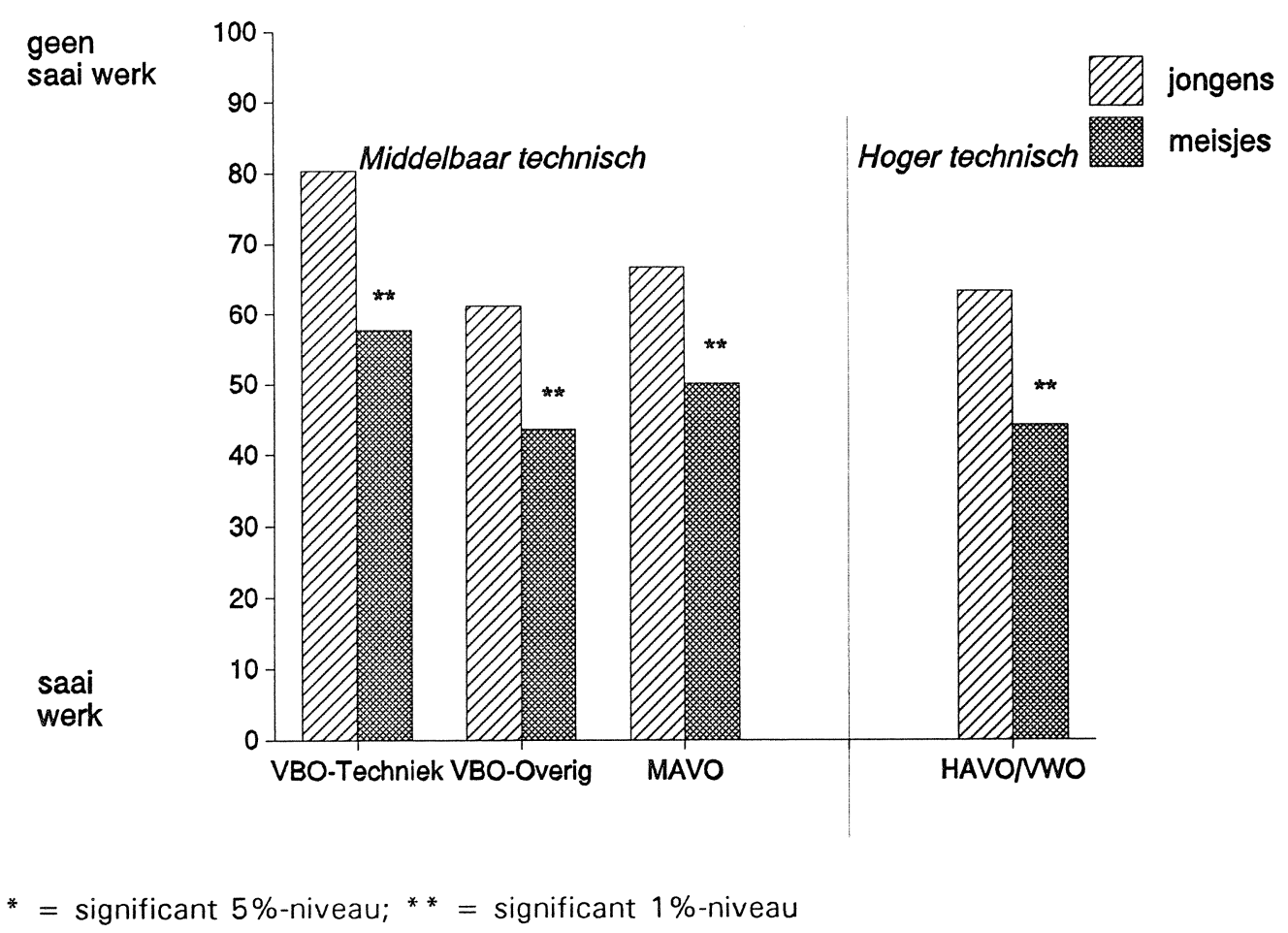

Ook van dit kwalitatieve aspect van het werk kan een vergelijking worden gemaakt tussen het beeld dat de leerlingen hebben en de feitelijke situatie. In tabel 8.7. wordt een overzicht 
$-64-$

gegeven van het deel van de werkenden dat vaak saai werk moet doen ${ }^{9}$. Van de MTOopgeleiden zegt circa $30 \%$ regelmatig saai werk te moeten doen. Bij de MAO- en de MEAOopgeleiden is dit aandeel ongeveer even groot, terwijl MDGO-opgeleiden relatief vaak saai werk hebben. Opvallend is dat de leerlingen van het VBO-Overig het werkveld van de MDGOopgeleiden als het minst saai typeren. Met name bij deze leerlingen bestaat er derhalve een discrepantie tussen hun beeldvorming en de daadwerkelijke situatie. Voor leerlingen van het VBO-Techniek en het MAVO stemt het beeld dat zij op dit punt van het technisch onderwijs hebben redelijk overeen met de feitelijke situatie, ofschoon daarbij moet worden opgemerkt dat meisjes dit iets te negatief inschatten.

Tabel 8.7. Aandeel werkenden dat aangeeft dat saai werk hoofdzakelijk tot hun werk behoort naar opleidingsniveau en -richting

Opleiding saai werk

$\%$

Middelbaar agrarisch onderwijs 32

Middelbaar technisch onderwijs $\quad 31$

Middelbaar economisch-administratief onderwijs $\quad 30$

Middelbaar dienstverlenend/gezondheidszorg onderwijs $\quad 50$

Hoger onderwijs: pedagogisch/letteren $\quad 20$

Hoger onderwijs: agrarisch 31

Hoger onderwijs: technisch $r$

Hoger onderwijs: economisch/juridisch $r$

Hoger onderwijs: sociaal-cultureel

Hoger onderwijs: gezondheidszorg/medisch $\quad 25$

Bron: OSA

De hoger technisch opgeleiden (zowel HBO- als WO-niveau) beschouwen hun werk in vergelijking tot de andere richtingen op het vergelijkbare niveau als het minst saai. Het beeld dat de leerlingen hebben stemt dus niet overeen met de feitelijke situatie. Vooral het werkveld van de medisch opgeleiden wordt op dit punt door de leerlingen te positief ingeschat. Tot slot kan worden opgemerkt dat de OSA-gegevens helaas geen detaillering toestaan naar opleidingsniveau en -richting en geslacht. Derhalve kan niet goed worden nagegaan of technisch opgeleide vrouwen relatief vaker saai werk hebben dan hun mannelijke collega's, zoals het beeld dat de vrouwelijke leerlingen hebben suggereert.

\subsection{Zelfstandigheid}

Het laatste kwalitatieve aspect van het werk dat in deze paragraaf aan de orde komt, betreft de mate van zelfstandigheid in de beroepsuitoefening. Uit de in bijlage $D$ weergegeven tabellen 8.8a. tot en met 8.8e. blijkt dat VBO-Techniek-leerlingen denken dat MTO-opgeleiden het vaakst dingen in hun werk zelfstandig kunnen regelen. Bijna $45 \%$ van de leerlingen denkt dat de

9. In de OSA-vragenlijst is dit opgenomen als "herhaling van dezelfde eenvoudige werkzaamheden". 
$-65-$

kans op een beroep met veel zelfstandigheid voor deze opleidingscategorie het grootst is. De leerlingen denken dat daarna de middelbaar agrarisch opgeleiden de meeste zelfstandigheid in hun werk hebben. Voor MEAO-ers en MDGO-ers wordt de kleinste kans op een beroep met veel zelfstandigheid verwacht.

In tegenstelling tot de leerlingen van het VBO-Techniek, verwachten de VBO-Overig-leerlingen dat schoolverlaters van het MTO verhoudingsgewijs het vaakst in beroepen terecht komen waarbij je niet veel zelfstandig kunt regelen. De beeldvorming van de andere drie onderscheiden opleidingsrichtingen is niet veel van elkaar verschillend, ofschoon wel kan worden opgemerkt dat er erg grote verschillen zijn in het beeld dat men op dit punt heeft van het werkveld van MEAO-ers. Bijna een derde deel van de leerlingen verwacht dat MEAO-opgeleiden de grootste kans op een baan met veel zelfstandigheid hebben, terwijl een ongeveer even groot deel denkt dat MEAO-ers juist de kleinste kans hebben op werk waarin men veel zelfstandig kan regelen.

De MAVO-leerlingen zien in het middelbaar agrarisch onderwijs een opleiding waarmee men relatief vaak een beroep kan uitoefenen dat een grote zelfstandigheid kent. Ook voor MEAO-ers wordt een vrij positief beeld op dit punt verwacht. Het middelbaar technisch onderwijs neemt duidelijk een middenpositie in, terwijl de MAVO-ers voor de schoolverlaters van het MDGO de slechtste perspectieven op een beroep met veel zelfstandigheid verwachten.

Ook de leerlingen van het HAVO zien als positief aspect van een agrarische opleiding de verwachte kans op een beroep met veel zelfstandigheid. Daarnaast wordt voor de afgestudeerden van het hoger economisch onderwijs verwacht dat men naar verhouding veel dingen in het werk zelfstandig kan regelen. Voor het hoger sociaal-cultureel onderwijs, het hoger technisch onderwijs en het hoger gezondheidszorgonderwijs is het imago met betrekking tot de kans op een beroep met veel zelfstandigheid niet gunstig, maar ook niet ongunstig te noemen. De kleinste kans op het zelfstandig kunnen uitoefenen van de functie wordt toegedicht aan de afgestudeerden van het hoger pedagogisch onderwijs.

De VWO-leerlingen denken eveneens dat de agrarische en de economische richting de meeste kans op een baan met een grote mate van zelfstandigheid biedt. Ook de afgestudeerden in de technische wetenschappen wordt verhoudingsgewijs een redelijke mate van zelfstandigheid toegedicht. Degenen die een studie in de medische wetenschappen hebben afgerond, hebben volgens de leerlingen van het VWO de kleinste kans op een beroep met veel zelfstandigheid.

Uit figuur 8.5. blijkt dat meisjes een significant negatiever beeld hebben van de mate van zelfstandigheid die technisch opgeleiden in hun werk hebben. Dit geldt voor de leerlingen van alle vier onderscheiden opleidingscategorieën. Bij de leerlingen van het VBO-Techniek is de beeldvorming op dit punt het meest gunstig. De leerlingen van het VBO-Overig, en dan met name de meisjes, denken het meest negatief over het technisch onderwijs ten aanzien van de verwachte mate van zelfstandigheid in de toekomstige beroepsuitoefenening van technisch opgeleiden. 
Figuur 8.5. Het relatieve imago van het technisch onderwijs met betrekking tot de kans op een beroep met veel zelfstandigheid naar opleidingscategorie en geslacht

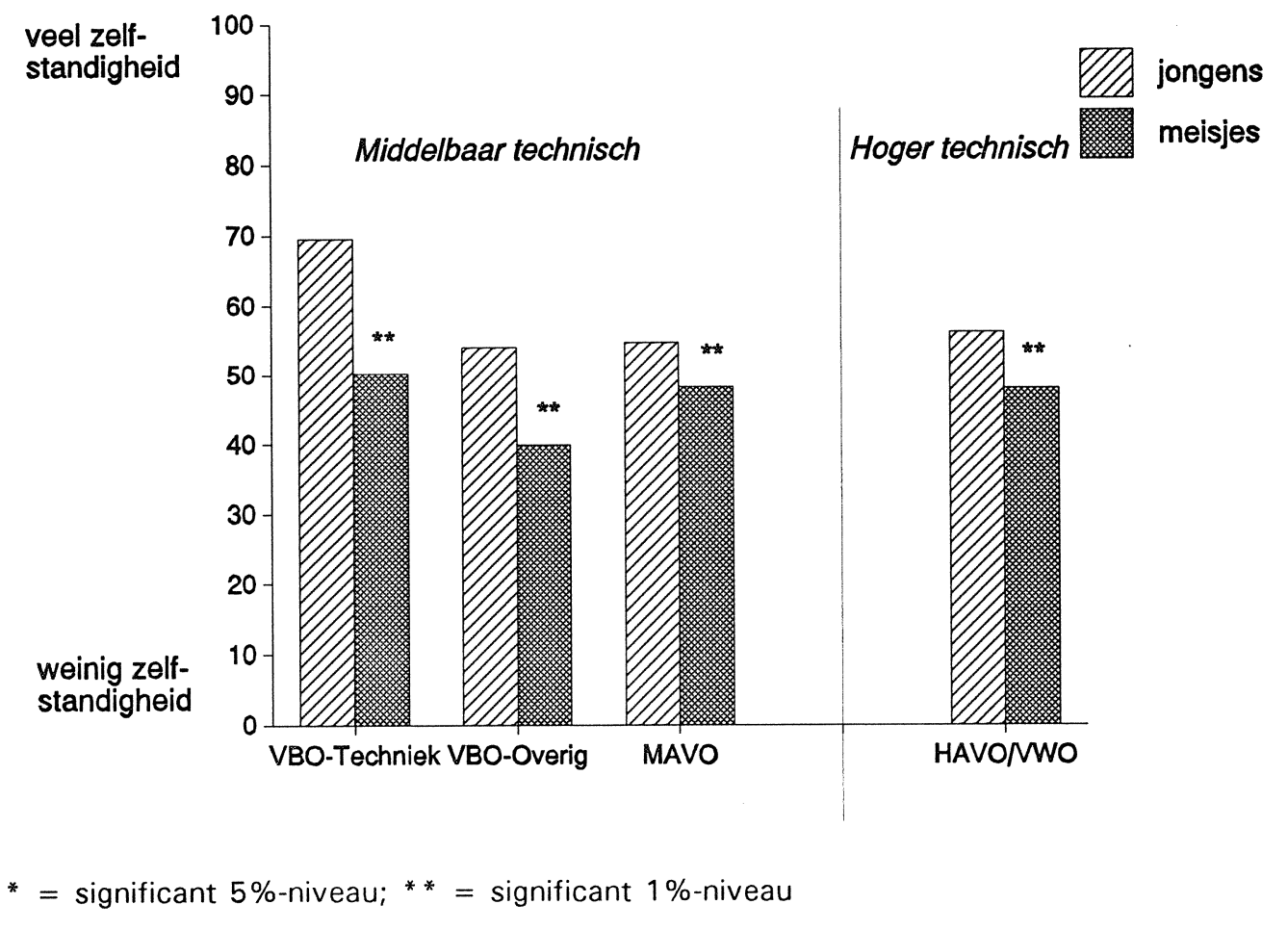

Tabel 8.9. Aandeel werkenden dat aangeeft dat zelfstandig werk hoofdzakelijk tot hun werk behoort naar opleidingsniveau en -richting

Opleiding

zelfstandig werk

$\%$

Middelbaar agrarisch onderwijs

Middelbaar technisch onderwijs

Middelbaar economisch-administratief onderwijs

84

Middelbaar dienstverlenend/gezondheidszorg onderwijs

Hoger onderwijs: pedagogisch/letteren

Hoger onderwijs: agrarisch

Hoger onderwijs: technisch

Hoger onderwijs: economisch/juridisch

Hoger onderwijs: sociaal-cultureel

Hoger onderwijs: gezondheidszorg/medisch 
In tabel 8.9. wordt een beeld geschetst van de feitelijke situatie op dit punt, zoals waargenomen in de OSA-arbeidsaanbodenquête ${ }^{10}$. Ook op het punt van de mate van zelfstandigheid die men in het werk heeft, blijkt het beeld dat de leerlingen van het werk van technisch opgeleiden hebben iets te ongunstig. Dit is vooral het geval bij de leerlingen van het VBO-Overig. Ook de HAVO/VWO-leerlingen blijken ten onrechte te denken dat men met andere dan de technische richting een grotere kans heeft op een baan die een grote mate van zelfstandigheid biedt. Met name het economisch/juridisch onderwijs heeft ten onrechte een beter imago dan het hoger en universitair technisch onderwijs.

\subsection{Kwalitatieve aspecten van het werk van technisch opgeleiden}

In deze paragraaf zal worden getracht om relaties te leggen tussen het beeld dat de leerlingen hebben van de vijf hierboven genoemde kwalitatieve aspecten van het werk van technisch opgeleiden en enkele persoons-, omgevings- of andere min of meer individuele kenmerken. Daartoe is een multivariate analyse ${ }^{11}$ verricht, waarvan de resultaten worden gepresenteerd in tabel 8.10. Het blijkt dat meisjes een iets negatievere kijk op de kwaliteit van de arbeid van technisch opgeleiden hebben dan jongens. De verschillen zijn echter alleen voor het VBO-Overig en het HAVO/VWO significant. Opmerkelijk is verder dat de VBO-leerlingen uit de etnische minderheidsgroepen een significant negatiever beeld hebben van het werk van technisch opgeleiden.

Uit de tabel blijkt verder dat de leerlingen uit het noorden van het land iets negatiever zijn over de kwalitatieve werkgelegenheidsaspecten van technisch opgeleiden dan de leerlingen in de rest van het land, waarbij het verschil bij de HAVO/VWO-leerlingen significant is. Wellicht kan dit worden verklaard uit het feit dat in het noorden van het land de meer traditionele industrieën sterker zijn vertegenwoordigd, welke mogelijk meer worden gekenmerkt door minder goede secundaire arbeidsomstandigheden. Het opleidingsniveau en de beroepsrichting van de ouders is vrijwel niet van invloed op het beeld dat de leerlingen hebben van de kwalitatieve aspecten van het werk van technisch opgeleiden in vergelijking met de andere opleidingscategorieën.

Tot slot wordt een positief verband geconstateerd tussen het imago van het werkveld van technisch opgeleiden en de interesse voor techniek in het algemeen. Dit is overeenkomstig het beeld dat in hoofdstuk 7 naar voren is gekomen ten aanzien van de verwachte arbeidsmarktpositie. Overigens is het verband bij het VBO-Overig niet significant. Er wordt verder geen significant verband waargenomen tussen het verwachte secundaire arbeidsomstandigheden van technisch opgeleiden bij de leerlingen en hun houding ten opzichte van de mogelijke economische en andere maatschappelijke consequenties van technologische ontwikkeling.

10. De corresponderende vraag in de OSA-enquête is "[Bestaat uw werk] hoofdzakelijk uit werk waaraan je zelf nog iets kunt regelen?".

11. De indicator voor het imago van de kwalitatieve aspecten van het werk van technisch opgeleiden is bepaald als het ongewogen gemiddelde van de vijf onderliggende indicatoren. Overigens kan worden opgemerkt dat de (hier niet weergegeven) resultaten van afzonderlijke multivariate analyses naar elk van de onderscheiden elementen van de kwaliteit van de arbeid een soortgelijk beeld laten zien. 
Tabel 8.10. Schattingsresultaten van een multivariate analyse van de gepercipieerde relatieve kwalitatieve aspecten van het werk van technisch opgeleiden naar opleidingscategorie (standaardfouten tussen haakjes)

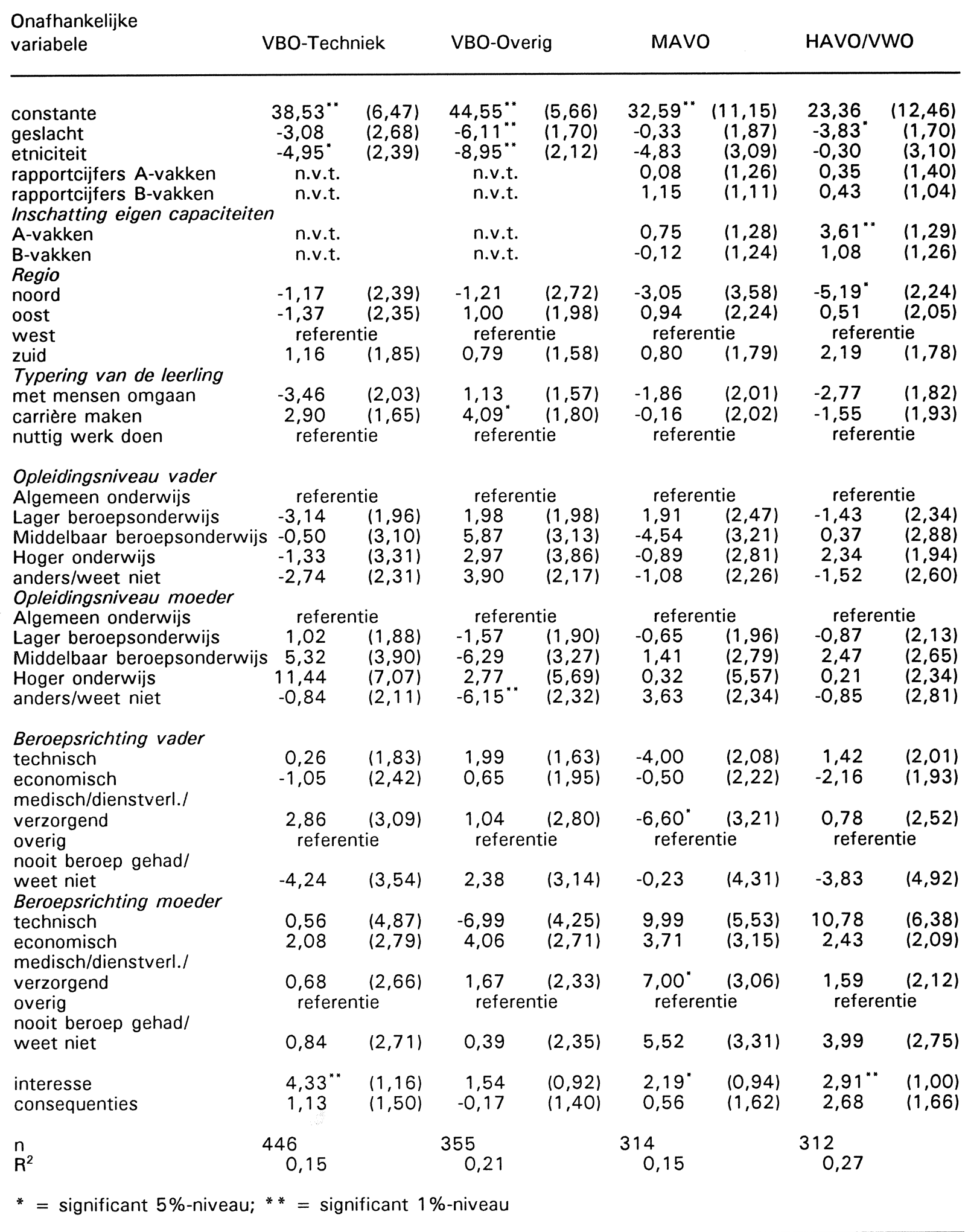




\section{HET IMAGO VAN HET TECHNISCH ONDERWIJS IN VOGELVLUCHT}

Het derde deel van het rapport beschrijft het beeld dat de leerlingen hebben van het technisch onderwijs en het werkveld waarin men met een technische opleiding terecht komt. Dit is in dit rapport geoperationaliseerd als de verwachtingen van de leerlingen ten aanzien van verschillende opleidingsmogelijkheden die direct aansluiten op het niveau van hun huidige opleiding. Daarbij is een onderscheid gemaakt tussen drie facetten van het imago:

- de moeilijkheidsgraad van de opleiding;

- de arbeidsmarktpositie: werk en inkomen;

- enkele kwalitatieve aspecten van het werk.

Het imago van het technisch onderwijs wordt daarbij telkens gezien in verhouding tot het imago van de andere opleidingsrichtingen, zodat tevens zicht wordt verkregen op de opleidingsrichtingen die op een bepaald punt een grotere aantrekkingskracht hebben dan het technisch onderwijs. Op deze wijze wordt in feite de concurrentiepositie die het technisch onderwijs inneemt in de studie- en beroepskeuzebeslissingen in beeld gebracht.

Vooral op de hogere niveaus ( $\mathrm{HBO}$ en WO) heeft het technisch onderwijs bij de leerlingen een vrij negatief imago op het punt van de verwachte moeilijkheidsgraad. Veel HAVO/VWOleerlingen verwachten dat het technisch onderwijs de moeilijkste richting is. Bij meisjes is dit beeld daarbij nog extremer dan bij jongens. De VBO- en MAVO-leerlingen rekenen het middelbaar technisch onderwijs weliswaar ook tot de moeilijkere richtingen, maar het middelbaar economisch-administratief onderwijs is naar hun verwachting moeilijker. Uit de uitgevoerde analyses is verder gebleken dat de VBO-Overig-leerlingen die tot een etnische minderheidsgroep behoren de technische richting vaker als een moeilijke opleidingsrichting inschatten.

Voorts is ingegaan op de verwachte arbeidsmarktpositie van technisch opgeleiden, waarbij een onderscheid is gemaakt tussen de kans op werk en de relatieve inkomenspositie. In het algemeen blijkt dat de leerlingen de kans op werk voor technisch opgeleiden vrij gunstig inschatten. Opvallend daarbij is wel dat meisjes een veel negatiever beeld van de werkgelegenheidssituatie van technisch opgeleiden hebben dan jongens. Daarnaast blijkt dat de leerlingen van het VBO-Overig negatiever aankijken tegen de kans op werk voor degenen die een technische opleiding hebben afgerond. Deze leerlingen verwachten dat MDGO- en MEAOschoolverlaters gemakkelijker een baan kunnen vinden.

Een vergelijkbaar verwachtingspatroon bestaat er bij de leerlingen ten aanzien van de verwachte kans op een relatief hoog inkomen. Ook hier is het beeld dat de jongeren van het technisch onderwijs hebben vrij gunstig. Meisjes schatten de (toekomstige) inkomenspositie van technisch opgeleiden weliswaar ook op dit punt iets minder positief in, maar het verschil met de jongens is duidelijk kleiner dan ten aanzien van de verwachte kans op werk met een technisch opleiding. VBO-Overig en MAVO-leerlingen hebben het minst gunstige beeld van de verwachte inkomenspositie van technisch opgeleiden. Zij verwachten dat MEAO-opgeleiden het meest zullen verdienen. 
Behalve het verschil tussen jongens en meisjes ten aanzien van de verwachte arbeidsmarktpositie van technisch opgeleiden, zijn er nog enkele andere kenmerken van de leerlingen van invloed op het imago dat het technisch onderwijs op dit punt bij hen heeft. Zo hebben MAVOleerlingen die hogere cijfers halen voor de B-vakken een positiever beeld van de verwachte arbeidsmarktpositie van technisch opgeleiden. De beroepsrichting en het opleidingsniveau van de beide ouders heeft vrijwel geen invloed op de beeldvorming van de leerlingen op dit punt. Wel blijkt er een positief verband te bestaan tussen enerzijds de interesse voor techniek en de houding ten opzichte van de mogelijke consequenties van technologische vernieuwingen en anderzijds de verwachtingen ten aanzien van de relatieve positie van technisch opgeleiden op de arbeidsmarkt.

Het hierboven beschreven beeld dat de leerlingen hebben van de arbeidsmarktpositie van technisch opgeleiden is ook vergeleken met meer feitelijke informatie hierover. In het algemeen kan worden geconcludeerd dat de leerlingen vrij goed op de hoogte zijn van de daadwerkelijke situatie op de arbeidsmarkt voor wat betreft de relatieve kans op werk en de inkomensverhoudingen tussen de verschillende opleidingsrichtingen. Wel heeft men een verhoudingsgewijs te rooskleurig beeld van de arbeidsmarktpositie van economisch opgeleiden, hetgeen vanzelfsprekend een negatief effect heeft op de verwachte relatieve positie van het technisch onderwijs. Verder kan worden opgemerkt dat er op basis van de momenteel beschikbare arbeidsmarktgegevens geen aanwijzingen zijn dat de relatieve positie van technisch opgeleide vrouwen slechter is dan de relatieve positie van mannen met de desbetreffende opleidingsachtergrond. Het negatievere imago dat het technisch onderwijs bij meisjes heeft, lijkt derhalve ongegrond.

Het derde onderdeel van het imago van het technisch onderwijs dat in dit deel van het rapport aan de orde is geweest, heeft betrekking op de kwalitatieve aspecten van het werk waarin de leerlingen denken met een bepaalde vervolgopleiding terecht te komen. Daarbij zijn achtereenvolgens vijf aspecten nader belicht:

- lichamelijk zwaar werk;

- $\quad$ stress;

- vuil werk;

- $\quad$ saai werk;

- $\quad$ werk met veel zelfstandigheid.

Een groot deel van de leerlingen denkt dat technisch opgeleiden relatief vaak lichamelijk zwaar werk moeten verrichten. Vooral bij de leerlingen van het VBO-Techniek is het beeld van het technisch onderwijs op dit punt erg negatief. Het bij de leerlingen verwachte beeld ten aanzien van de kans op een psychisch zware baan ('stress') voor technisch opgeleiden is daarentegen veel gunstiger. De jongeren verwachten doorgaans niet dat technisch opgeleiden vaak met stress in hun werk te maken krijgen.

De kans op een beroep waarbij men vaak vuil werk moet doen wordt echter voor technisch opgeleiden weer vrij groot geacht. Daarbij is het opmerkelijk dat opnieuw de VBO-Techniek- 
leerlingen hier het meest negatief tegen aan kijken. Daarnaast hebben de meisjes van het VBOOverig en het HAVO/VWO een duidelijk negatiever beeld van de kwaliteit van het werk van technisch opgeleiden op dit punt dan de jongens van deze opleidingscategorieën. Ten aanzien van de verwachte kans op saai werk bestaat er een duidelijk verschil van inzicht tussen jongens en meisjes. Terwijl jongens het werk van technisch opgeleiden bij uitstek als niet saai typeren, schatten meisjes de kans op saai werk in verhouding tot de andere opleidingsrichtingen veel groter in. Een dergelijk verschillend beeld bestaat er eveneens ten aanzien van de verwachte mate van zelfstandigheid die technisch opgeleiden verhoudingsgewijs hebben. De kans voor technisch opgeleiden op een baan die men zelfstandig kan uitoefenen wordt door meisjes relatief lager ingeschat dan door jongens. Het beeld dat jongens van het technisch onderwijs op dit punt hebben is overwegend gunstig, maar minder positief dan het beeld met betrekking tot de verwachte kans op een niet saaie baan.

Ook voor de kwalitatieve aspecten van het werk is een multivariate analyse verricht om de belangrijkste determinanten te achterhalen van het beeld dat de leerlingen hebben van het werkveld van technisch opgeleiden. Meisjes hebben iets minder positieve verwachtingen ten aanzien van de kwaliteit van de arbeid van technisch opgeleiden in vergelijking met de andere opleidingscategorieën. Opvallend is verder dat leerlingen van etnische minderheidsgroepen een duidelijk negatiever beeld hebben van de kwalitatieve aspecten van het werk van technisch opgeleiden dan autochtone leerlingen. Voorts blijkt dat de leerlingen die in het noorden van het land wonen op dit punt iets negatiever zijn. Evenals bij de verwachte (kwantitatieve) arbeidsmarktpositie van technisch opgeleiden, wordt bij de kwalitatieve werkgelegenheidsaspecten een positieve relatie waargenomen met de interesse die de leerlingen hebben in techniek. Er is op dit punt echter geen duidelijk verband met de houding van de leerlingen ten opzichte van de maatschappelijke en economische gevolgen van de technologische ontwikkeling.

De percepties van de leerlingen ten aanzien van de kwalitatieve aspecten van het werk van technisch opgeleiden in verhouding tot de andere opleidingsrichtingen zijn eveneens vergeleken met de beschikbare meer feitelijke gegevens hierover. Het blijkt dat het beeld dat de leerlingen hebben van de kwalitatieve aspecten van het werk van technisch opgeleiden minder in overeenstemming is met de werkelijkheid dan hun beeld van de meer kwantitatieve verhoudingen op de arbeidsmarkt. Vooral de kans om met een technische opleiding in een fysiek zware baan terecht te komen, wordt door de leerlingen te negatief ingeschat. Dit geldt zowel voor de lagere als voor de hogere niveaus. Daar staat tegenover dat met name de VBO- en de MAVO-leerlingen op dit punt een te gunstig beeld hebben van het dienstverlenend en gezondheidszorgonderwijs. Bovendien denken de leerlingen ten onrechte dat technisch opgeleiden vaker vuil werk moeten doen. Vooral op hoger niveau is nauwelijks sprake van vuil werk. Met name de VBO-Overig-leerlingen staan te negatief tegenover de kans op saai werk voor technisch opgeleiden en de mate van zelfstandigheid die technisch opgeleiden verhoudingsgewijs in hun werk hebben. Ten aanzien van de kans op saai werk is de beeldvorming onder deze leerlingen van het werkveld van MDGO-opgeleiden te gunstig. Verder zien zij voor de opgeleiden in de economische richting ten onrechte een relatief te grote mate 
$-72-$

van zelfstandigheid. Bij de HAVO/VWO-leerlingen heeft met name het economisch/juridisch onderwijs ten onrechte een beter imago ten aanzien van de zelfstandigheid dit men in het werk heeft dan het hoger en universitair technisch onderwijs. 
DEEL IV

DE KEUZE VOOR TECHNIEK 



\section{DE KEUZE NA HET BASISONDERWIJS EN DE VAKKENPAKKETKEUZE IN HET ALGEMEEN VOORTGEZET ONDERWIJS}

\subsection{De keuze na het basisonderwijs}

In dit vierde deel van het rapport staat de keuze voor techniek centraal. Eerst wordt daarbij in dit hoofdstuk achtereenvolgens ingegaan op de keuze na het basisonderwijs en de pakketkeuze van de leerlingen op het AVO. In hoofdstuk $11 \mathrm{komt}$ vervolgens de opleidings- en/of beroepsrichtingkeuze na het (huidige) voortgezet onderwijs aan bod, met als centrale invalshoek de keuze voor techniek.

Tabel 10.1. geeft een overzicht van het opleidingsadvies dat de leerlingen op de basisschool hebben gekregen, verbijzonderd naar hun huidige opleidingscategorie en geslacht. Het blijkt dat bij de meeste opleidingscategorieën ruim $60 \%$ van de leerlingen het advies van de basisschool heeft opgevolgd. Bij de meisjes van het VBO-Overig heeft $83 \%$ het door de basisschool gegeven advies opgevolgd.

Tabel 10.1. Advies van de basisschool naar opleidingscategorie en geslacht

\begin{tabular}{|c|c|c|c|c|c|c|c|c|}
\hline \multirow[t]{2}{*}{ Advies } & \multicolumn{2}{|c|}{ VBO-Techniek } & \multicolumn{2}{|c|}{ VBO-Overig } & \multicolumn{2}{|c|}{ MAVO } & \multicolumn{2}{|c|}{ HAVO/VWO } \\
\hline & j & m & j & m & j & $\mathrm{m}$ & j & $\mathrm{m}$ \\
\hline & $\%$ & $\%$ & $\%$ & $\%$ & $\%$ & $\%$ & $\%$ & $\%$ \\
\hline LBO & 36 & 38 & 35 & 40 & 3 & 6 & 2 & 2 \\
\hline LBO/MAVO & 30 & 29 & 31 & 43 & 12 & 20 & 2 & 4 \\
\hline MAVO & 17 & 15 & 11 & 7 & 33 & 36 & 9 & 6 \\
\hline MAVO/HAVO & 8 & 10 & 11 & 6 & 31 & 26 & 14 & 18 \\
\hline HAVO & 2 & 1 & 0 & - & 10 & 5 & 13 & 14 \\
\hline HAVO/VWO & 2 & 3 & 0 & 1 & 8 & 7 & 30 & 33 \\
\hline VWO & 1 & - & - & 0 & 1 & 0 & 28 & 23 \\
\hline weet niet (meer) & 4 & 4 & 12 & 2 & 2 & 1 & 1 & - \\
\hline $\mathrm{N}$ & 293 & 38 & 96 & 275 & 340 & 341 & 399 & 510 \\
\hline
\end{tabular}

Zoals blijkt uit tabel 10.2., is het advies van de basisschool voor veel leerlingen niet de belangrijkste reden waarom men voor de huidige opleiding heeft gekozen. Dit geldt vooral voor de VBO-leerlingen. Als belangrijkste reden voor de keuze van de huidige opleiding wordt door de leerlingen aangegeven: 'omdat ik dat zelf wilde'. Niet verrassend is verder dat de VBO-leerlingen relatief vaak aangeven dat het beroep dat men later wil uitoefenen een belangrijke reden voor de opleidingskeuze is geweest. Ook de mogelijkheid tot het volgen van bepaalde vervolgopleidingen wordt door deze leerlingen vrij vaak als reden genoemd. Dit laatste is ook door een grote groep HAVO/VWO-leerlingen als een belangrijk argument voor hun opleidingskeuze genoemd. De mening van de ouders is daarentegen voor het overgrote deel van de VBO- 
leerlingen niet doorslaggevend voor hun huidige opleidingskeuze. Bij de AVO-leerlingen, en dan met name bij de MAVO-ers, is de mening van de ouders wel bij nogal wat leerlingen van belang geweest.

Tabel 10.2. Redenen voor de keuze van de huidige opleiding naar opleidingscategorie en geslacht

\begin{tabular}{|c|c|c|c|c|c|c|c|c|}
\hline \multirow[t]{2}{*}{ Redenen } & \multicolumn{2}{|c|}{ VBO-Techniek } & \multicolumn{2}{|c|}{ VBO-Overig } & \multicolumn{2}{|c|}{ MAVO } & \multicolumn{2}{|c|}{ HAVO/VWO } \\
\hline & j & $\mathrm{m}$ & j & $\mathrm{m}$ & $\mathrm{j}$ & $\mathrm{m}$ & j & m \\
\hline & $\%$ & $\%$ & $\%$ & $\%$ & $\%$ & $\%$ & $\%$ & $\%$ \\
\hline \multicolumn{9}{|l|}{ omdat ik dat advies van de } \\
\hline $\begin{array}{l}\text { basisschool kreeg } \\
\text { omdat mijn ouders/verzorgers }\end{array}$ & 16 & 19 & 15 & 28 & 41 & 43 & 38 & 35 \\
\hline dat wilden & 5 & 9 & 7 & 12 & 22 & 24 & 19 & 13 \\
\hline omdat ik dat zelf wilde & 72 & 77 & 64 & 67 & 53 & 69 & 77 & 79 \\
\hline omdat mijn vrienden/vriendinnen & 3 & 6 & 3 & 8 & 8 & 10 & 8 & 11 \\
\hline omdat deze opleiding nodig is voor de & & & & & & & & \\
\hline opleiding die ik hierna wil volgen & 23 & 29 & 23 & 25 & 17 & 11 & 30 & 22 \\
\hline $\begin{array}{l}\text { omdat deze opleiding nodig is voor het } \\
\text { beroep dat ik later wil uitoefenen }\end{array}$ & 43 & 27 & 39 & 24 & 8 & 5 & 15 & 10 \\
\hline om een andere reden & $\begin{array}{r}43 \\
8\end{array}$ & 17 & $\begin{array}{l}39 \\
11\end{array}$ & $\begin{array}{l}24 \\
18\end{array}$ & 20 & $\begin{array}{r}5 \\
15\end{array}$ & $\begin{array}{l}15 \\
11\end{array}$ & 12 \\
\hline $\mathrm{N}$ & 294 & 38 & 96 & 279 & 342 & 346 & 400 & 512 \\
\hline
\end{tabular}

Tabel 10.3. Informatiebronnen over de keuze van de huidige opleiding naar opleidingscategorie en geslacht

\begin{tabular}{|c|c|c|c|c|c|c|c|c|}
\hline \multirow[t]{2}{*}{ Informatiebronnen } & \multicolumn{2}{|c|}{ VBO-Techniek } & \multicolumn{2}{|c|}{ VBO-Overig } & \multicolumn{2}{|c|}{ MAVO } & \multicolumn{2}{|c|}{ HAVO/VWO } \\
\hline & j & $\mathrm{m}$ & $\mathrm{j}$ & m & $\mathrm{j}$ & $\mathrm{m}$ & $\mathrm{j}$ & m \\
\hline & $\%$ & $\%$ & $\%$ & $\%$ & $\%$ & $\%$ & $\%$ & $\%$ \\
\hline onderwijzer(es) basisschool & 58 & 65 & 56 & 67 & 72 & 71 & 74 & 75 \\
\hline ouders/verzorgers & 33 & 39 & 37 & 33 & 38 & 37 & 41 & 48 \\
\hline vrienden/vriendinnen & 10 & 10 & 16 & 11 & 12 & 12 & 10 & 10 \\
\hline folders of kennismakingsdagen & & & & & & & & \\
\hline $\begin{array}{l}\text { van de scholen } \\
\text { kranten tiidschriften }\end{array}$ & 45 & 41 & 43 & 42 & 40 & 37 & 48 & 42 \\
\hline $\begin{array}{l}\text { kranten, tijdschriften, } \\
\text { radio of televisie }\end{array}$ & 7 & 5 & 3 & 3 & 6 & 3 & 7 & 6 \\
\hline andere manier & 8 & 12 & 6 & 7 & 10 & 10 & 4 & 9 \\
\hline $\mathrm{N}$ & 291 & 37 & 96 & 278 & 342 & 341 & 392 & 511 \\
\hline
\end{tabular}

Tabel 10.3. geeft aan op welke manier de leerlingen iets te weten zijn gekomen over de opleidingen die men na de basisschool kon kiezen. De onderwijzer(es) van de basisschool blijkt 
de belangrijkste informatiebron bij de opleidingskeuze na de basisschool. Opvallend daarbij is echter dat de VBO-leerlingen dit minder vaak noemen. Dit zou er wellicht op kunnen duiden dat aan de mogelijkheden om een opleiding in het VBO te kiezen op de basisschool weinig aandacht wordt besteed.

Verder blijkt uit de tabel dat folders en kennismakingsdagen van de scholen een belangrijke bron van informatie vormen. Ook de ouders blijken een belangrijke informatiebron te zijn. Vrienden/ vriendinnen en radio of televisie blijken slechts in geringe mate te fungeren als informatiebron voor de keuze van het voortgezet onderwijs.

Uit tabel 10.4. blijkt dat in het algemeen slechts weinig leerlingen spijt hebben van hun keuze voor de huidige opleiding in het voortgezet onderwijs. De jongens van het MAVO hebben het vaakst spijt van hun keuze. Voor het merendeel waren deze spijtoptanten liever naar het HAVO/VWO gegaan. Ook VBO-Techniek wordt echter een aantal malen als alternatief genoemd.

Tabel 10.4. Spijt van de keuze voor de huidige opleiding naar opleidingscategorie en geslacht

\begin{tabular}{|c|c|c|c|c|c|c|c|c|}
\hline & \multicolumn{2}{|c|}{ VBO-Techniek } & \multicolumn{2}{|c|}{ VBO-Overig } & \multicolumn{2}{|c|}{ MAVO } & \multicolumn{2}{|c|}{ HAVO/VWO } \\
\hline & j & $\mathrm{m}$ & $\mathrm{j}$ & $\mathrm{m}$ & $\mathrm{j}$ & $\mathrm{m}$ & j & m \\
\hline & $\%$ & $\%$ & $\%$ & $\%$ & $\%$ & $\%$ & $\%$ & $\%$ \\
\hline geen spijt & 95 & 88 & 93 & 91 & 85 & 92 & 97 & 95 \\
\hline wel spijt & 5 & 13 & 7 & 9 & 15 & 8 & 3 & 5 \\
\hline $\mathrm{N}$ & 290 & 39 & 96 & 275 & 340 & 345 & 399 & 510 \\
\hline liever gedaan: & & & & & & & & \\
\hline MAVO & 23 & 57 & 53 & 63 & & & - & 10 \\
\hline HAVO/VWO & 30 & 29 & 17 & 15 & 78 & 82 & 67 & 80 \\
\hline VBO-Techniek & 23 & - & - & 3 & 13 & 5 & - & - \\
\hline VBO-Overig & 18 & - & - & 16 & 5 & 9 & 24 & \\
\hline anders & 7 & 14 & 31 & 4 & 5 & 5 & 9 & 10 \\
\hline $\mathrm{N}$ & 12 & 4 & 6 & 23 & 49 & 26 & 13 & 22 \\
\hline
\end{tabular}

\subsection{De vakkenpakketkeuze in het algemeen voortgezet onderwijs}

De leerlingen van het algemeen voortgezet onderwijs is gevraagd naar hun vakkenpakketkeuze. Bij het HAVO gaat het om de feitelijke pakketkeuze, terwijl de MAVO- en de VWO-leerlingen alleen kunnen aangeven welke vakken zij waarschijnlijk gaan kiezen. De door de leerlingen samengestelde vakkenpakketten zijn door ons ingedeeld naar de vier 'doorstroomprofielen', zoals die mogelijk in de toekomst voor het HAVO/VWO zullen gelden (zie Ministerie van Onderwijs en Wetenschappen, 1991 en 1992). Deze profielen zijn echter niet volledig compatibel te maken met de huidige mogelijkheden die de leerlingen hebben bij hun vakkenpakketkeuze. Een groot aantal van de huidige vakken zal namelijk in de nieuwe opzet 
worden opgesplitst in twee deelvakken, één algemeen deelvak en één meer specifiek deelvak ${ }^{1}$. Bovendien kunnen momenteel allerlei vakkenpakketten worden gekozen, die na de invoering van de doorstroomprofielen in het voortgezet onderwijs niet meer mogelijk zijn.

De huidige plannen gaan uit van vier doorstroomprofielen voor zowel het HAVO als het VWO. Voor het MAVO wordt vooralsnog echter gesproken over drie profielen. In dit rapport zullen desondanks de gekozen vakkenpakketten voor het gehele AVO worden gerubriceerd volgens vier profielen, waarbij door ons de volgende criteria zijn gehanteerd:

- bij de keuze voor (1) wiskunde (wiskunde A of wiskunde B), (2) natuurkunde en (3) scheikunde: profiel 'Natuur en techniek';

- bij de keuze voor (1) frans, duits of engels, (2) economie/handelskennis en (3) wiskunde (A of B), maar geen biologie: profiel 'Economie en maatschappij';

- bij de keuze voor (1) frans of duits en (2) geschiedenis: profiel 'Cultuur en maatschappij';

- bij de keuze voor (1) wiskunde (A of B) en (2) biologie: profiel 'Natuur en gezondheidszorg'.

Indien een vakkenpakket volgens deze criteria in meer dan één profiel zou passen, dan is dit ingedeeld bij het eerstgenoemde profiel van de hierboven gepresenteerde opsomming. Daarnaast is het mogelijk dat een vakkenpakket aan geen van de vier genoemde criteria voldoet. Verder moet worden beseft dat de indeling van de huidige vakkenpakketten in de genoemde doorstroomprofielen enigszins arbitrair is. Wanneer de leerlingen uitsluitend uit deze vier profielen kunnen kiezen zal de daadwerkelijke keuze mogelijk hiervan afwijken. Desalniettemin geeft de bovenstaande indeling ongetwijfeld toch een duidelijke weergave van de voorkeuren die onder de leerlingen van het AVO leven.

Tabel 10.5. geeft een overzicht van de keuzes voor een bepaald doorstroomprofiel. Het blijkt duidelijk dat er een sterk significant verschil is tussen de vakkenpakketkeuzes van jongens en meisjes. Jongens kiezen veel vaker voor het profiel 'Natuur en techniek', terwijl meisjes relatief dikwijls een voorkeur uitspreken voor het profiel 'Natuur en gezondheidszorg' ${ }^{2}$. In het algemeen wordt echter het profiel 'Economie en maatschappij' het vaakst gekozen. Het profiel 'Cultuur en maatschappij' is daarentegen het minst populair. Overigens kan worden opgemerkt dat van de VWO-leerlingen een aanzienlijk groter deel voor 'Natuur en techniek' kiest dan van de leerlingen van de andere AVO-opleidingen.

Uit de tabel kan worden geconcludeerd dat door de pakketkeuze in het AVO met name voor meisjes een loopbaan in de techniek reeds grotendeels wordt uitgesloten. Op MAVO-niveau speelt dit nog iets sterker dan op HAVO/VWO-niveau. Deze pakketkeuzes, en vanzelfsprekend ook de keuze voor het VBO-Overig die door een aantal leerlingen op nog jongere leeftijd wordt gemaakt, houden in dat al op vrij jonge leeftijd het potentieel voor de technische richting sterk wordt gereduceerd.

1. Dit is enigszins vergelijkbaar met de huidige opdeling van het vak wiskunde in wiskunde $A$ en wiskunde $\mathrm{B}$.

2. De Jong, Oosterbeek, Roeleveld en Webbink (1992) vinden een soortgelijk beeld. 
Tabel 10.5. Keuze van het 'doorstroomprofiel' door MAVO- en HAVO/VWO-leerlingen naar geslacht

\begin{tabular}{|c|c|c|}
\hline Doorstroomprofiel & MAVO & HAVO/VWO \\
\hline & j m & j $\quad \mathrm{m}$ \\
\hline
\end{tabular}

\begin{tabular}{|c|c|c|c|c|}
\hline & $\%$ & $\%$ & $\%$ & $\%$ \\
\hline Natuur en techniek & 37 & 15 & 41 & 20 \\
\hline Natuur en gezondheidszorg & 16 & 46 & 9 & 22 \\
\hline Economie en maatschappij & 41 & 25 & 44 & 35 \\
\hline Cultuur en maatschappij & 7 & 15 & 7 & 23 \\
\hline N & 280 & 230 & 358 & 419 \\
\hline Cramer's V & \multicolumn{2}{|c|}{$0,39^{* *}$} & \multicolumn{2}{|c|}{$0,33^{* *}$} \\
\hline
\end{tabular}

In de tabellen 10.6a. tot en met 10.6b., die zijn opgenomen in bijlage $D$, wordt een overzicht gegeven van de redenen waarom leerlingen bepaalde vakken wel of juist niet hebben gekozen of denken te gaan kiezen. Daarbij is gekeken naar vijf vakken, te weten frans, geschiedenis, wiskunde (voor MAVO-leerlingen) of wiskunde B (voor HAVO/VWO-leerlingen), natuurkunde en handelskennis (MAVO), economie (HAVO) of economie I (VWO).

In het algemeen kan worden geconcludeerd dat de cijfers voor het vak, of men het vak al dan niet leuk vindt en of men het vak moeilijk of juist makkelijk vindt de belangrijkste redenen zijn waarom leerlingen een bepaald vak al dan niet kiezen. Bij de keuze voor de vakken wiskunde en natuurkunde hebben de leerlingen zich ook laten leiden door het argument dat men dit vak nodig (denkt te) hebben voor de vervolgopleiding die men wil gaan volgen of het beroep dat men later graag wil uitoefenen. Aan de andere kant is ook de beslissing om wiskunde of natuurkunde niet te kiezen vaak ingegeven door het niet nodig hebben van deze vakken voor de vervolgopleiding of het beroep dat men voor ogen heeft.

Verder is het opmerkelijk dat de ouders volgens de leerlingen geen belangrijke invloed hebben op de keuze van het vakkenpakket, terwijl zij bij de keuze voor de huidige (AVO-lopleiding nog wel een belangrijke stem hadden. Tot slot is het opvallend dat aan de mening van de docenten en de dekaan slechts een geringe invloed wordt toebedeeld. Alleen de keuze van HAVO/VWOleerlingen om wiskunde $B$ niet te kiezen schijnt redelijk vaak te zijn voortgekomen uit een advies van de docenten of de dekaan. 


\section{DE KEUZE NA DE HUIDIGE OPLEIDING}

\subsection{De keuze tussen leren en werken}

In dit hoofdstuk wordt ingegaan op de voorgenomen studie- of beroepskeuze aan het einde van de huidige opleiding. De nadruk ligt daarbij op de vraag of de leerlingen al dan niet voor de technische richting kiezen. Daarbij zal telkens een beeld worden geschetst van de (univariate) relatie tussen dit keuzegedrag en diverse persoons- en omgevingskenmerken. Ook wordt gekeken of er een relatie bestaat tussen dit keuzegedrag en de waardering voor techniek en het beeld dat de leerlingen hebben van het technisch onderwijs en de technische beroepen. Tenslotte zal met behulp van een multivariate analyse een overzicht worden gegeven van de factoren die daadwerkelijk van invloed zijn op de keuze van leerlingen om al dan niet voor de technische richting te kiezen.

Tabel 11.1. geeft aan wat de leerlingen van de onderscheiden opleidingscategorieën na hun huidige opleiding van plan zijn te gaan doen: leren, werken of eventueel een combinatie van beide. Van de VBO-leerlingen wil circa $70 \%$ verder gaan leren. Ongeveer $10 \%$ is van plan te gaan werken. De overige leerlingen kiezen vrijwel allemaal voor een opleiding in het leerlingwezen of een in-service opleiding. Bij het AVO willen slechts enkele leerlingen direct na hun huidige opleiding gaan werken. Van de MAVO-ers wil ruim $10 \%$ na het eindexamen gaan werken in combinatie met leren. Bij het HAVO/VWO is dit nog geen $5 \%$. Kortom, het overgrote deel van de leerlingen wil na hun huidige opleiding nog een andere full-time opleiding volgen.

Tabel 11.1. Plannen na de huidige opleiding naar opleidingscategorie en geslacht

\begin{tabular}{|c|c|c|c|c|c|c|c|c|}
\hline \multirow[t]{2}{*}{ Plannen } & \multicolumn{2}{|c|}{ VBO-Techniek } & \multicolumn{2}{|c|}{ VBO-Overig } & \multicolumn{2}{|c|}{ MAVO } & \multicolumn{2}{|c|}{ HAVO/VWO } \\
\hline & j & m & j & $\mathrm{m}$ & j & $m$ & $\mathrm{j}$ & m \\
\hline & $\%$ & $\%$ & $\%$ & $\%$ & $\%$ & $\%$ & $\%$ & $\%$ \\
\hline verder leren & 66 & 80 & 72 & 70 & 87 & 88 & 96 & 94 \\
\hline werken & 10 & 8 & 10 & 7 & 2 & 1 & 1 & 1 \\
\hline werken en leren & 23 & 13 & 18 & 22 & 11 & 11 & 4 & 5 \\
\hline eigen huishouden & 0 & - & - & 2 & - & - & - & - \\
\hline $\mathrm{N}$ & 293 & 39 & 96 & 279 & 342 & 345 & 400 & 512 \\
\hline Cramer's V & & 10 & & 0,09 & & 0,04 & & 0,04 \\
\hline
\end{tabular}

In de in bijlage D opgenomen tabellen 11.2a. tot en met 11.2b. is voor de leerlingen, die hebben aangegeven dat zij na hun huidige opleiding verder willen leren, weergegeven welke vervolgopleiding zij van plan zijn te gaan volgen. Daarbij moet worden bedacht dat het hier gaat om de voorkeuren op een tijdstip dat bijna twee jaar voor het eindexamen ligt (voor de VWO-leerlingen zelfs bijna drie jaar). Dit betekent dat de uiteindelijke keuzes van het hier gepresenteerde beeld 
zouden kunnen afwijken ${ }^{3}$.

Het blijkt dat ruim $80 \%$ van de mannelijke VBO-Techniek-leerlingen die verder willen leren, kiezen voor een opleiding in het MTO. Opvallend is echter dat van de meisjes van het VBOTechniek slechts ongeveer $20 \%$ voor het MTO kiest. Een groot gedeelte van deze meisjes verdwijnt derhalve uiteindelijk toch uit de technische richting. De belangrijkste concurrentie komt hier van het MDGO (zowel de medische als de verzorgende richting). Wellicht hangt de geringe doorstroom van deze groep meisjes naar het MTO samen met het feit dat meisjes binnen het VBO-Techniek vaak richtingen als consumptieve techniek volgen ${ }^{4}$. Overigens moet hierbij ook worden opgemerkt dat er slechts weinig vrouwelijke VBO-Techniek-leerlingen in de enquête zijn opgenomen.

Zoals mocht worden verwacht, gaat van de doorleerders van het VBO-Overig het merendeel naar het MEAO en het MDGO. Opvallend is echter dat van de jongens van het VBO-Overig toch nog $14 \%$ bij een technische opleiding (MTO) terecht komt. Voor het grootste deel betreft dit een doorstroom vanuit het lager agrarisch onderwijs.

Ruim een derde van de MAVO-leerlingen wil na de huidige opleiding (eerst) naar het HAVO. Ongeveer een kwart van de jongens die na het MAVO verder willen gaan leren, kiest voor het MTO. Bij de meisjes is dit slechts $4 \%$. Bij hen zijn het MDGO en het MEAO de meest populaire vervolgopleidingen.

Ook bij het HAVO-ers wil een vrij groot gedeelte van de leerlingen (22\%) eerst een algemeen voortgezette vervolgopleiding (VWO) gaan volgen. Bij degenen die kiezen voor een beroepsopleiding is de belangstelling voor het technisch onderwijs vrij gering ${ }^{5}$. Voor de jongens komt de grootste concurrentie daarbij van het economisch-administratief onderwijs IMEAO en HEAO), terwijl bij de meisjes naast het economisch-administratief onderwijs ook een relatief hoge doorstroom naar het pedagogisch onderwijs (PABO, Lerarenopleidingen) wordt geconstateerd. Van de VWO-leerlingen is een vrij groot gedeelte van plan een technische vervolgopleiding te kiezen. Ook bij de meisjes is de doorstroom naar een technische studierichting in vergelijking met het MAVO en het HAVO hoog. Daarnaast gaat de grootste belangstelling van de jongens van het VWO uit naar het economisch onderwijs, terwijl bij meisjes een studie in de medische wetenschappen vrij populair is.

3. Voor meer gegevens over de doorstroom binnen het onderwijs en de uitstroom uit het onderwijs wordt verwezen naar de Onderwijsmatrices van het Centraal Bureau voor de Statistiek (CBS).

4. Zoals reeds eerder aangegeven, verschaft de enquête over de richtingkeuze binnen de onderscheiden VBO-sectoren geen informatie.

5. Overigens kan een aantal leerlingen via het VWO alsnog in de techniek terecht komen (zie bijvoorbeeld Van Dijck, 1991). Op grond van de vakkenpakketkeuze van de HAVO-leerlingen is een relatief hoge doorstroom naar de technische richting voor de onderzochte groep echter niet waarschijnlijk. 
Van de jongens van het VBO-Techniek, die niet full-time willen verder leren, wil ruim $70 \%$ een technisch beroep uitoefenen (zie tabel 11.3. in bijlage D). Bij de meisjes die na hun VBOTechniek-opleiding willen gaan werken (of werken en leren) kiest, evenals bij de meisjes die verder willen leren, slechts een beperkt gedeelte voor een technisch beroep. Van de jongens die momenteel een opleiding in het VBO-Overig volgen en die niet of niet full-time verder willen leren, kiest een beperkt gedeelte voor een technisch beroep.

Zoals bleek uit tabel 11.1., wil slechts een klein deel van de AVO-leerlingen direct na hun huidige opleiding gaan werken. Van de jongens die direct na het MAVO-eindexamen wel willen gaan werken, kiezen de meesten een technisch of een veiligheidsberoep. Bij de meisjes van deze opleidingscategorie heeft het grootste deel een voorkeur voor een dienstverlenend beroep. De zeer kleine groep jongens die direct na de HAVO/VWO-opleiding wil gaan werken, kiezen vooral voor technische beroepen, terwijl de meisjes van het HAVO/VWO met name belangstelling hebben voor een beroep in de medische sfeer.

\subsection{De keuze voor techniek}

In deze paragraaf zal vanuit verschillende invalshoeken nader worden belicht welke leerlingen na de opleiding die zij nu volgen al dan niet voor de technische richting kiezen. Daarbij wordt verder geen onderscheid gemaakt tussen een technische vervolgopleiding en een technisch beroep. Figuur 11.1. geeft een totaaloverzicht van de keuze voor techniek, verbijzonderd naar opleidingscategorie en geslacht. In de figuur zijn daarbij de leerlingen die (eerst) een algemeen voortgezette vervolgopleiding kiezen buiten beschouwing gelaten.

Figuur 11.1. De keuze voor techniek naar opleidingscategorie en geslacht

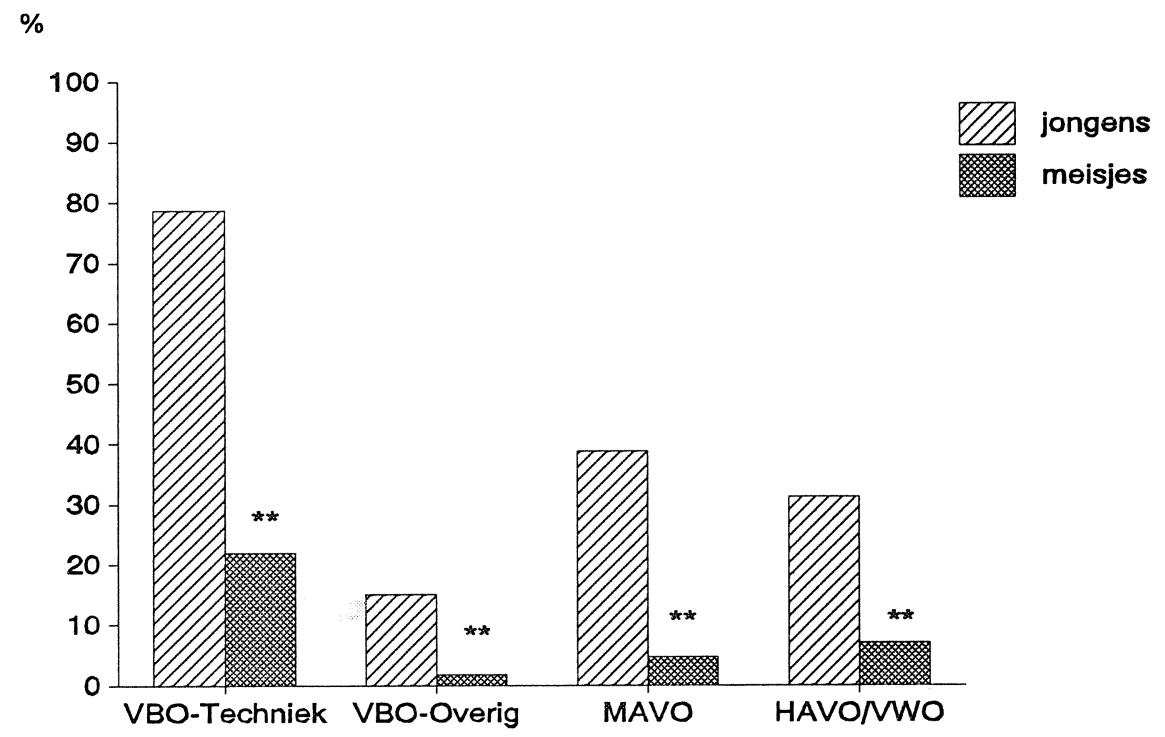

* = significant $5 \%$-niveau; * $=$ significant $1 \%$-niveau 
Totaal gezien wil minder dan de helft van de jongens en slechts ongeveer $5 \%$ van de meisjes in de techniek terecht komen. Daarbij geldt voor alle opleidingscategorieën dat het aandeel dat voor techniek kiest bij meisjes significant veel lager is dan bij jongens. Zoals reeds aangegeven, is de belangstelling voor de techniek het grootst bij de VBO-Techniek-leerlingen en het geringst bij de leerlingen van het VBO-Overig. Van de mannelijke MAVO-leerlingen wil bijna $40 \%$ de technische richting in. Bij het HAVO/VWO is dit ruim $30 \%$. Zoals in de vorige paragraaf reeds is aangegeven, kiezen de HAVO-leerlingen aanmerkelijk minder vaak voor de technische richting dan de VWO-leerlingen. Van de vrouwelijke AVO-leerlingen kiest slechts een klein gedeelte uiteindelijk voor techniek.

\section{Opleidingsniveau van de ouders}

Tabel 11.4. De keuze voor verschillende vervolgrichtingen naar geslacht en opleidingsniveau van de ouders/verzorgers (rijpercentages per geslacht)

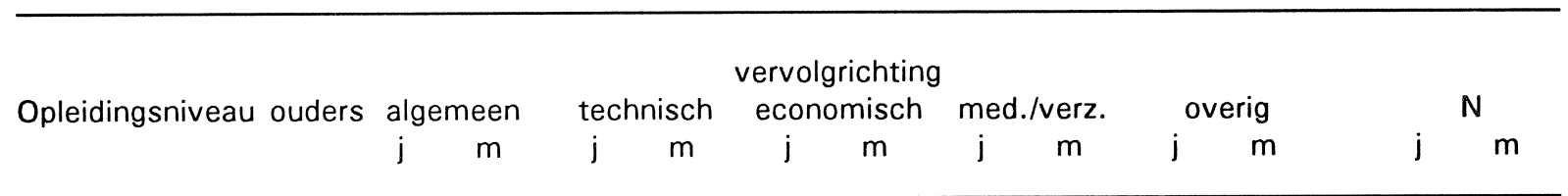

Opleidingsniveau vader/verzorger

$\begin{array}{lrrrrrrrrrrrr}\text { Lager onderwijs } & 6 & 10 & 47 & 1 & 20 & 20 & 8 & 49 & 19 & 19 & 76 & 50 \\ \text { MAVO } & 21 & 18 & 38 & 4 & 14 & 23 & 5 & 35 & 22 & 19 & 146 & 173 \\ \text { HAVO/VWO } & 19 & 22 & 34 & 1 & 22 & 13 & 7 & 32 & 17 & 30 & 83 & 103 \\ \text { LBO } & 5 & 15 & 50 & 6 & 21 & 15 & 6 & 41 & 18 & 24 & 207 & 233 \\ \text { MBO } & 16 & 6 & 42 & 4 & 20 & 29 & 8 & 32 & 14 & 29 & 70 & 60 \\ \text { HBO } & 15 & 14 & 41 & 7 & 22 & 18 & 8 & 25 & 15 & 35 & 82 & 80 \\ \text { Universiteit } & 32 & 27 & 28 & 8 & 15 & 17 & 11 & 28 & 14 & 20 & 72 & 68 \\ \text { anders/weet niet } & 14 & 14 & 36 & 4 & 24 & 20 & 5 & 42 & 20 & 19 & 239 & 254\end{array}$

verschil tussen vervolgrichtingen bij jongens: Cramer's $\mathrm{V}=0,11^{\prime \prime}$ verschil tussen vervolgrichtingen bij meisjes: Cramer's $V=0,11^{* *}$

Opleidingsniveau moeder/verzorgster

$\begin{array}{lrrrrrrrrrrrr}\text { Lager onderwijs } & 11 & 12 & 34 & 8 & 28 & 31 & 10 & 39 & 17 & 11 & 65 & 56 \\ \text { MAVO } & 12 & 20 & 39 & 4 & 20 & 18 & 5 & 33 & 25 & 25 & 241 & 244 \\ \text { HAVO/VWO } & 28 & 28 & 29 & 4 & 20 & 17 & 9 & 22 & 15 & 28 & 78 & 95 \\ \text { LBO } & 9 & 10 & 53 & 3 & 18 & 17 & 5 & 46 & 15 & 24 & 210 & 318 \\ \text { MBO } & 16 & 15 & 46 & 4 & 18 & 4 & 3 & 47 & 17 & 30 & 73 & 70 \\ \text { HBO } & 19 & 27 & 29 & 5 & 19 & 11 & 13 & 21 & 18 & 36 & 26 & 51 \\ \text { Universiteit } & 24 & 22 & 16 & 20 & 30 & 30 & 13 & 13 & 18 & 15 & 20 & 22 \\ \text { anders/weet niet } & 17 & 12 & 37 & 6 & 21 & 28 & 7 & 40 & 18 & 12 & 265 & 171\end{array}$

verschil tussen vervolgrichtingen bij jongens: Cramer's $V=0,11^{*}$ verschil tussen vervolgrichtingen bij meisjes: Cramer's $V=0,16^{* *}$

* = significant $5 \%$-niveau; ${ }^{*}=$ significant $1 \%$-niveau

In tabel 11.4. is de keuze van de leerlingen voor de verschillende vervolgrichtingen gerelateerd aan het opleidingsniveau van de ouders. Het blijkt dat er zowel bij de jongens als bij de meisjes 
een significante relatie bestaat tussen hun richtingkeuze en het opleidingsniveau van de beide ouders. Voor meisjes geldt bovendien dat het opleidingsniveau van de moeder van meer belang is voor de vervolgkeuze dan het opleidingsniveau van de vader. Van de jongens, waarvan de vader een academische opleiding heeft gevolgd, kiest slechts een relatief klein deel (direct) voor de technische richting. Bij de meisjes is een dergelijk verband niet aanwezig. Opvallend genoeg blijkt bij de meisjes, dat degenen waarvan de moeder een hogere opleiding (HBO of universiteit), of een hogere algemene opleiding (HAVO/VWO) heeft gevolgd, relatief minder vaak de 'traditionele' medisch/verzorgende richting kiezen en vaker in de technische richting terecht willen komen.

Beroepsrichting van de ouders

Tabel 11.5. De keuze voor verschillende vervolgrichtingen naar geslacht en beroepsrichting van de ouders/verzorgers (rijpercentages per geslacht)

Beroepsrichting ouders $\begin{array}{cccccccc}\text { vervolgrichting } & \text { overig } & N & N\end{array}$

Beroepsrichting vader/verzorger

\begin{tabular}{|c|c|c|c|c|c|c|c|c|c|c|c|c|}
\hline technisch & 9 & 17 & 48 & 5 & 20 & 18 & 7 & 39 & 17 & 21 & 367 & 331 \\
\hline economisch & 20 & 15 & 33 & 5 & 26 & 19 & 6 & 32 & 15 & 28 & 256 & 265 \\
\hline \multicolumn{13}{|c|}{ medisch/dienstverlenend/ } \\
\hline verzorgend & 23 & 19 & 33 & 6 & 22 & 11 & 9 & 45 & 13 & 20 & 87 & \\
\hline overig & 14 & 14 & 38 & 3 & 14 & 20 & 6 & 39 & 28 & 24 & 210 & \\
\hline weet niet & 3 & 20 & 50 & 3 & 14 & 27 & 10 & 35 & 20 & 13 & 41 & \\
\hline
\end{tabular}

verschil tussen vervolgrichtingen bij jongens: Cramer's $V=0,14^{* *}$

verschil tussen vervolgrichtingen bij meisjes: Cramer's $V=0,09$

\section{Beroepsrichting moeder/verzorgster}

\begin{tabular}{|c|c|c|c|c|c|c|c|c|c|c|c|c|}
\hline technisch & 12 & 7 & 48 & 25 & 5 & 28 & 11 & 30 & 24 & 10 & 20 & 17 \\
\hline economisch & 18 & 19 & 35 & 4 & 24 & 19 & 8 & 34 & 16 & 24 & 243 & 238 \\
\hline \multicolumn{13}{|c|}{ medisch/dienstverlenend/ } \\
\hline verzorgend & 15 & 14 & 41 & 4 & 16 & 16 & 6 & 41 & 22 & 25 & 312 & \\
\hline $\begin{array}{l}\text { overig } \\
\text { nooit beroep gehad/ }\end{array}$ & 15 & 17 & 39 & 9 & 20 & 24 & 10 & 22 & 17 & 28 & 121 & \\
\hline weet niet & 11 & 14 & 44 & 3 & 26 & 20 & 3 & 45 & 15 & 15 & 245 & \\
\hline
\end{tabular}

verschil tussen vervolgrichtingen bij jongens: Cramer's $V=0,09^{*}$

verschil tussen vervolgrichtingen bij meisjes: Cramer's $V=0,13^{* *}$

* = significant $5 \%$-niveau; * ${ }^{*}=$ significant $1 \%$-niveau

Tabel 11.5. geeft een beeld van de keuze van de leerlingen voor de verschillende vervolgrichtingen in relatie tot de beroepsrichting van de ouders. Het blijkt dat jongens zich in het algemeen meer laten 'leiden' door het beroep van de vader en meisjes meer door het beroep van de moeder. Zo kiezen jongens waarvan de vader een technisch beroep heeft of heeft 
gehad, zelf ook verhoudingsgewijs vaak voor de technische richting. Overigens moet hierbij worden opgemerkt dat jongens waarvan de vader niet in de technische richting werkzaam is, relatief vaak eerst nog een algemeen voortgezette vervolgopleiding gaan volgen. Deze leerlingen zouden daarna alsnog in de technische richting terecht kunnen komen. Bij meisjes wordt een soortgelijk beeld waargenomen. Meisjes, waarvan de moeder een medisch beroep uitoefent of heeft uitgeoefend, kiezen zelf ook vaker voor deze richting.

\section{Algemene typering van de leerling}

In de enquête is de leerlingen ook gevraagd wat zij voor zichzelf het belangrijkste voor de toekomst vinden: met mensen omgaan, carrière maken of nuttig werk doen. Op deze manier kan enigszins worden aangegeven of een leerling meer 'sociaal-georiënteerd', meer 'materialistisch-georiënteerd, dan wel meer 'idealistisch-georiënteerd' is. In tabel 11.6. is de keuze voor de verschillende vervolgrichtingen uitgezet tegen deze wat zou kunnen worden genoemd 'algemene typering van de leerling'.

Tabel 11.6. De keuze voor verschillende vervolgrichtingen naar geslacht en een algemene typering van de leerling (rijpercentages per geslacht)

\begin{tabular}{|c|c|c|c|c|c|c|c|c|c|c|c|c|}
\hline \multirow[t]{2}{*}{$\begin{array}{l}\text { Belangrijkste voor } \\
\text { eigen toekomst }\end{array}$} & \multicolumn{2}{|c|}{ algemeen } & \multicolumn{2}{|c|}{ technisch } & \multicolumn{2}{|c|}{$\begin{array}{l}\text { vervolgrichting } \\
\text { economisch }\end{array}$} & \multicolumn{2}{|c|}{ med./verz. } & \multicolumn{2}{|c|}{ overig } & \multicolumn{2}{|r|}{$\mathrm{N}$} \\
\hline & j & m & j & $\mathrm{m}$ & j & $\mathrm{m}$ & j & m & j & $\mathrm{m}$ & j & m \\
\hline met mensen omgaan & 18 & 14 & 30 & 2 & 21 & 16 & 11 & 43 & 21 & 24 & 223 & 545 \\
\hline carrière maken & 15 & 20 & 40 & 5 & 26 & 31 & 6 & 24 & 13 & 20 & 446 & 236 \\
\hline nuttig werk doen & 11 & 16 & 48 & 11 & 12 & 15 & 6 & 36 & 23 & 22 & 306 & 244 \\
\hline \multicolumn{13}{|c|}{$\begin{array}{l}\text { verschil tussen vervolgrichtingen bij jongens: Cramer's } V=0,16^{* *} \\
\text { verschil tussen vervolgrichtingen bij meisjes: Cramer's } V=0,20^{* *}\end{array}$} \\
\hline
\end{tabular}

De tabel laat het te verwachten stereotiepe beeld zien. De leerlingen die het belangrijk vinden om met mensen om te gaan kiezen relatief dikwijls voor een vervolgopleiding of beroep in de medisch/verzorgende sfeer. Leerlingen die daarentegen een groot belang hechten aan een goede carrière, geven de economische richting relatief vaak als hun voorkeur aan, al moet daarbij worden opgemerkt dat bij de carrièregerichte jongens ook een grote groep voor de technische richting kiest. Verder vinden de leerlingen die voor de technische richting kiezen relatief vaak nuttig werk doen belangrijk. Overigens zijn de geschetste verschillen het meest duidelijk bij de meisjes zichtbaar.

Capaciteiten voor A- en B-vakken

Tabel 11.7. geeft een overzicht van de relatie tussen de keuze voor de verschillende vervolgrichtingen en de 'feitelijke' capaciteiten van de leerlingen, zoals die tot uiting komen in 
de rapportcijfers die men gemiddeld voor de A- en de B-vakken heeft behaald ${ }^{6}$. De tabel heeft alleen betrekking op de leerlingen van het AVO. Het blijkt dat de cijfers voor de A-vakken niet of nauwelijks een rol spelen bij de keuze voor een vervolgopleiding of een beroep. Een uitzondering op dit punt vormen de meisjes die gemiddeld een laag rapportcijfer voor de A-vakken hebben. Zij kiezen relatief vaak voor de medische of verzorgende richting.

Tabel 11.7. De keuze voor verschillende vervolgrichtingen door MAVO- en HAVO/VWO-leerlingen naar geslacht en gemiddelde rapportcijfers voor A- en B-vakken (rijpercentages per geslacht)

\begin{tabular}{|c|c|c|c|c|c|c|c|c|c|c|c|c|}
\hline \multirow[t]{2}{*}{ Gemiddeld cijfer } & \multicolumn{2}{|c|}{ algemeen } & \multicolumn{2}{|c|}{ technisch } & \multicolumn{2}{|c|}{$\begin{array}{l}\text { vervolgrichting } \\
\text { economisch }\end{array}$} & \multicolumn{2}{|c|}{ med./verz. } & \multicolumn{2}{|c|}{ overig } & \multicolumn{2}{|r|}{$\mathbf{N}$} \\
\hline & $\mathrm{j}$ & $\mathrm{m}$ & j & $\mathrm{m}$ & j & $\mathrm{m}$ & $\mathrm{j}$ & $\mathrm{m}$ & j & $\mathrm{m}$ & j & $m$ \\
\hline \multicolumn{13}{|l|}{ A-vakken } \\
\hline lager dan 6 & 26 & 18 & 29 & - & 18 & 27 & 2 & 45 & 24 & 10 & 77 & 54 \\
\hline tussen 6 en 7 & 22 & 21 & 27 & 6 & 29 & 18 & 8 & 30 & 15 & 26 & 312 & 333 \\
\hline minstens een 7 & 20 & 24 & 27 & 5 & 25 & 20 & 5 & 24 & 24 & 29 & 231 & 339 \\
\hline
\end{tabular}

verschil tussen vervolgrichtingen bij jongens: Cramer's $V=0,12$

verschil tussen vervolgrichtingen bij meisjes: Cramer's $V=0,12^{*}$

B-vakken

$\begin{array}{lllllllllllll}\text { lager dan 6 } & 21 & 20 & 6 & 3 & 43 & 21 & 2 & 28 & 28 & 28 & 68 & 137 \\ \text { tussen 6 en 7 } & 16 & 16 & 27 & 3 & 29 & 24 & 6 & 30 & 23 & 27 & 217 & 313 \\ \text { minstens een 7 } & 26 & 30 & 32 & 9 & 20 & 13 & 8 & 25 & 15 & 23 & 331 & 258\end{array}$

verschil tussen vervolgrichtingen bij jongens: Cramer's $V=0,19^{* *}$

verschil tussen vervolgrichtingen bij meisjes: Cramer's $V=0,16^{* *}$

* = significant $5 \%$-niveau; ${ }^{*}=$ significant $1 \%$-niveau

In tegenstelling tot de cijfers voor de A-vakken, is het gemiddeld rapportcijfer voor de B-vakken zowel bij jongens als bij meisjes wel van belang voor de richtingkeuze. Daarbij is de invloed bij jongens groter dan bij meisjes. Zoals mocht worden verwacht, hebben de cijfers voor de Bvakken een sterk selecterend effect op de keuze voor een technische vervolgrichting. Erg opvallend is echter dat meisjes die vrij hoog scoren voor de B-vakken (minstens een 7) toch slechts in geringe mate belangstelling hebben voor de technische richting. Slechts $9 \%$ van deze groep geeft aan door te willen gaan in de techniek, terwijl van de vergelijkbare groep jongens

6. Voor het gemiddeld cijfer voor de A-vakken wordt het gemiddelde genomen van de cijfers voor de vakken nederlands, frans, duits, engels, geschiedenis en aardrijkskunde, voorzover deze vakken in het schooljaar voorafgaand aan de enquête werden gevolgd. Het gemiddeld rapportcijfer voor de Bvakken is opgebouwd uit de cijfers voor wiskunde, natuurkunde, scheikunde en biologie, vanzelfsprekend ook voorzover deze vakken in het afgelopen schooljaar werden gevolgd. 
$32 \%$ aangeeft voor de technische richting te kiezen?. Hierbij moet echter wel worden opgemerkt dat een vrij groot deel van deze meisjes (eerst) naar een algemeen voortgezette opleiding doorstroomt.

Naast deze meer objectieve vaststelling van de capaciteiten van de leerlingen is ook aan de leerlingen gevraagd hoe zij zelf over hun capaciteiten voor de A- en de B-richting denken ${ }^{8}$. Uit de resultaten die zijn gepresenteerd in tabel 11.8. blijkt dat het beeld dat de leerlingen van hun eigen capaciteiten hebben significant van invloed is op hun vervolgkeuze. Het blijkt dat met name jongens die hun capaciteiten voor de A-vakken laag inschatten relatief vaak voor een technische richting kiezen. De leerlingen die hun capaciteiten voor de B-vakken hoog inschatten blijken verhoudingsgewijs vaak voor de technische richting te kiezen. Opmerkelijk daarbij is wel dat jongens veel vaker voor de techniek kiezen dan meisjes met een vergelijkbare perceptie van hun eigen kwaliteiten ten aanzien van de B-vakken. Bij de meisjes is ook voor degenen die zichzelf goed vinden in de B-vakken de medisch/verzorgende richting het meest populair.

Tabel 11.8. De keuze voor verschillende vervolgrichtingen door MAVO- en HAVO/VWO-leerlingen naar geslacht en de subjectieve inschatting van de eigen capaciteiten voor A- en B-vakken (rijpercentages per geslacht)

\begin{tabular}{|c|c|c|c|c|c|c|c|}
\hline \multirow{2}{*}{ Inschatting capaciteiten } & \multirow{2}{*}{$\begin{array}{l}\text { algemeen } \\
\mathrm{j} \quad \mathrm{m}\end{array}$} & technisch & $\begin{array}{c}\text { vervolgrichting } \\
\text { economisch }\end{array}$ & med./verz. & overig & \multicolumn{2}{|c|}{$\mathrm{N}$} \\
\hline & & $\mathrm{j} \quad \mathrm{m}$ & j m & $\mathrm{j} \quad \mathrm{m}$ & j m & j & $\mathrm{m}$ \\
\hline
\end{tabular}

$\begin{array}{llllllllllllr}\text { A-vakken } & & & & & & & & & & & & \\ & 26 & 17 & 44 & 7 & 15 & 14 & 2 & 39 & 13 & 22 & 72 & 77 \\ \text { laag } & 18 & 22 & 31 & 6 & 27 & 20 & 7 & 31 & 17 & 21 & 273 & 370 \\ \text { gemiddeld } & 25 & 22 & 19 & 3 & 27 & 21 & 6 & 22 & 24 & 32 & 266 & 285 \\ \text { hoog } & 25\end{array}$

verschil tussen vervolgrichtingen bij jongens: Cramer's $V=0,16^{* *}$ verschil tussen vervolgrichtingen bij meisjes: Cramer's $V=0,15^{\text {"* }}$

B-vakken

\begin{tabular}{|c|c|c|c|c|c|c|c|c|c|c|c|}
\hline laag & 18 & 19 & 14 & 2 & 38 & 22 & 3 & 25 & 28 & 32 & 71 \\
\hline gemiddeld & 23 & 22 & 22 & 4 & 25 & 19 & 9 & 31 & 21 & 25 & 283 \\
\hline hoog & 22 & 29 & 35 & 13 & 23 & 13 & 4 & 31 & 16 & 13 & 277 \\
\hline
\end{tabular}

verschil tussen vervolgrichtingen bij jongens: Cramer's $V=0,16^{* *}$ verschil tussen vervolgrichtingen bij meisjes: Cramer's $V=0,19^{* *}$

* = significant $5 \%$-niveau; ${ }^{*}=$ significant $1 \%$-niveau

7. Enigszins vergelijkbaar is het resultaat van Van Heugten (1993), die vindt dat jongens op het VWO met een laag cijfer voor wiskunde toch relatief vaak voor wiskunde B kiezen, terwijl bij de vergelijkbare groep meisjes niet of nauwelijks het geval is.

8. Deze subjectieve inschatting van hun eigen capaciteiten is gebaseerd op uitspraken hierover met betrekking tot de vakken frans en geschiedenis voor de A-vakken en wiskunde en natuurkunde voor de B-vakken. 
Wanneer tabel 11.7. en tabel 11.8. met elkaar worden vergeleken, dan lijkt er vooral bij meisjes een discrepantie te bestaan tussen de feitelijke performance voor de B-vakken en de subjectieve inschatting van hun capaciteiten voor deze vakken. Om na te gaan of dat inderdaad het geval is, is in tabel 11.9. het verband weergegeven tussen de feitelijke capaciteiten, in de vorm van de gemiddelde rapportcijfers, en het beeld dat de leerlingen zelf van deze capaciteiten hebben.

Tabel 11.9. De relatie tussen de rapportcijfers en de subjectieve inschatting van de eigen capaciteiten voor A- en B-vakken voor MAVO- en HAVO/VWO-leerlingen naar geslacht (rijpercentages per geslacht)

\begin{tabular}{|c|c|c|c|c|c|c|c|c|}
\hline \multirow{3}{*}{ Rapportcijfer } & \multicolumn{6}{|c|}{ subjectieve inschatting eigen capaciteiten } & \multirow{2}{*}{\multicolumn{2}{|c|}{$\mathrm{N}$}} \\
\hline & \multicolumn{2}{|c|}{ laag } & \multicolumn{2}{|c|}{ gemiddeld } & \multicolumn{2}{|c|}{ hoog } & & \\
\hline & j & $\mathrm{m}$ & j & $\mathrm{m}$ & j & $\mathrm{m}$ & j & $\mathrm{m}$ \\
\hline \multicolumn{9}{|l|}{ A-vakken } \\
\hline lager dan 6 & 28 & 21 & 41 & 55 & 31 & 24 & 89 & 59 \\
\hline tussen 6 en 7 & 15 & 13 & 54 & 62 & 31 & 25 & 361 & 377 \\
\hline minstens een 7 & 2 & 5 & 32 & 41 & 66 & 55 & 251 & 406 \\
\hline \multicolumn{9}{|l|}{ B-vakken } \\
\hline lager dan 6 & 34 & 76 & 45 & 22 & 21 & 3 & 78 & 140 \\
\hline tussen 6 en 7 & 13 & 41 & 57 & 47 & 29 & 12 & 252 & 352 \\
\hline minstens een 7 & 3 & 14 & 36 & 48 & 61 & 37 & 388 & 307 \\
\hline
\end{tabular}

Uit de tabel blijkt dat jongens in het algemeen positiever over hun eigen capaciteiten zijn dan meisjes. Dit geldt zowel voor de A- als de B-vakken. De verschillen ten aanzien van de B-richting zijn daarbij echter het meest pregnant. Jongens schatten hun capaciteiten in vergelijking met hun rapportcijfers vrij positief in, terwijl meisjes juist erg negatief denken over hun mogelijkheden op dit punt. Zo vindt bijvoorbeeld slechts $34 \%$ van de jongens met gemiddeld minder dan een zes als rapportcijfer voor de B-vakken dat zij slecht zijn in de B-richting. Meest opvallend is echter dat nog geen $40 \%$ van de meisjes met gemiddeld meer dan een zeven voor de B-vakken zichzelf goed vindt in deze richting. Van deze meisjes denkt $14 \%$ zelfs dat zij slecht zijn in de B-richting.

\section{Waardering voor techniek}

Tabel 11.10. geeft een overzicht van de relatie tussen de keuze van de leerlingen voor de verschillende vervolgrichtingen en hun waardering ten aanzien van technologische vernieuwingen. Bij deze waardering is een onderscheid gemaakt tussen de interesse in techniek en de houding ten opzichte van de mogelijke gevolgen van de technologische ontwikkeling. In tegenstelling tot de drie voorgaande tabellen hebben de resultaten daarbij betrekking op het gehele voortgezet onderwijs en dus niet alleen op de AVO-leerlingen. 
Tabel 11.10. De keuze voor verschillende vervolgrichtingen naar geslacht en de waardering voor techniek (rijpercentages per geslacht)

\begin{tabular}{|c|c|c|c|c|c|c|}
\hline \multirow[t]{2}{*}{$\begin{array}{l}\text { Waardering } \\
\text { voor techniek }\end{array}$} & \multicolumn{5}{|c|}{$\begin{array}{l}\text { vervolgrichting } \\
\text { technisch economisch med./verz. }\end{array}$} & \multirow{2}{*}{${ }_{m}^{N}$} \\
\hline & $\mathrm{j} \quad \mathrm{m}$ & $\mathrm{j} \quad \mathrm{m}$ & j $\quad m$ & $\mathrm{j} \quad \mathrm{m}$ & j $\quad m$ & \\
\hline
\end{tabular}

Interesse

$\begin{array}{lrrrrrrrrrrrr}\text { laag } & 20 & 16 & 10 & 2 & 38 & 21 & 10 & 38 & 22 & 24 & 195 & 683 \\ \text { gemiddeld } & 18 & 17 & 30 & 8 & 21 & 17 & 9 & 38 & 22 & 20 & 395 & 296 \\ \text { hoog } & 8 & 15 & 63 & 20 & 12 & 12 & 3 & 29 & 13 & 24 & 415 & 68\end{array}$

verschil tussen vervolgrichtingen bij jongens: Cramer's $V=0,31^{* *}$ verschil tussen vervolgrichtingen bij meisjes: Cramer's $V=0,17^{* *}$

\section{Consequenties}

\begin{tabular}{|c|c|c|c|c|c|c|c|c|c|c|c|c|}
\hline laag & 13 & 10 & 21 & 3 & 17 & 22 & 6 & 36 & 44 & 28 & 22 & \\
\hline gemiddeld & 17 & 16 & 27 & 4 & 23 & 18 & 9 & 39 & 24 & 22 & 460 & 665 \\
\hline hoog & 12 & 17 & 52 & 7 & 19 & 20 & 5 & 34 & 13 & 23 & 523 & 335 \\
\hline
\end{tabular}

verschil tussen vervolgrichtingen bij jongens: Cramer's $V=0,20$ "*

verschil tussen vervolgrichtingen bij meisjes: Cramer's $V=0,08$

* = significant $5 \%$-niveau; $*$ * significant $1 \%$-niveau

Niet verbazingwekkend is dat het aandeel van de leerlingen dat kiest voor een technische vervolgrichting toeneemt naarmate men meer interesse heeft voor de techniek. Opvallend is echter dat van de meisjes met een grote interesse voor techniek toch slechts $20 \%$ uiteindelijk voor de technische richting denkt te gaan kiezen. Bij de jongens is dit $63 \%$.

De houding die de jongens aannemen tegenover mogelijke maatschappelijke en economische consequenties van technologische vernieuwing is eveneens van invloed op de vervolgkeuze. Van degenen die deze gevolgen van technologische vernieuwingen positiever inschatten gaat een groter deel verder in de technische richting. Bij de meisjes wordt een dergelijk effect echter nauwelijks waargenomen. Slechts $7 \%$ van de meisjes met een positief beeld van de maatschappelijke en economische consequenties van technologische vernieuwing kiest voor de technische richting.

\section{Imago van het technisch onderwijs}

Vervolgens wordt de relatie tussen de richtingkeuze van de leerlingen en het (relatieve) imago van het technisch onderwijs nader belicht. Daarbij wordt een onderscheid gemaakt naar de drie in deel III van dit rapport onderscheiden elementen: de moeilijkheidsgraad van de opleiding, de arbeidsmarktpositie van de schoolverlaters en de kwalitatieve aspecten van het werk. Eerst wordt in tabel 11.11. een beeld geschetst van de relatie tussen de keuze voor de verschillende vervolgrichtingen en het beeld dat de leerlingen hebben van de moeilijkheidsgraad van de 
opleiding. Het blijkt dat het verwachte beeld van de moeilijkheidsgraad van het technisch onderwijs vrijwel niet van invloed is op de keuze voor een bepaalde vervolgrichting.

Tabel 11.11. De keuze voor verschillende vervolgrichtingen naar geslacht en de verwachte moeilijkheidsgraad van het technisch onderwijs (rijpercentages per geslacht)

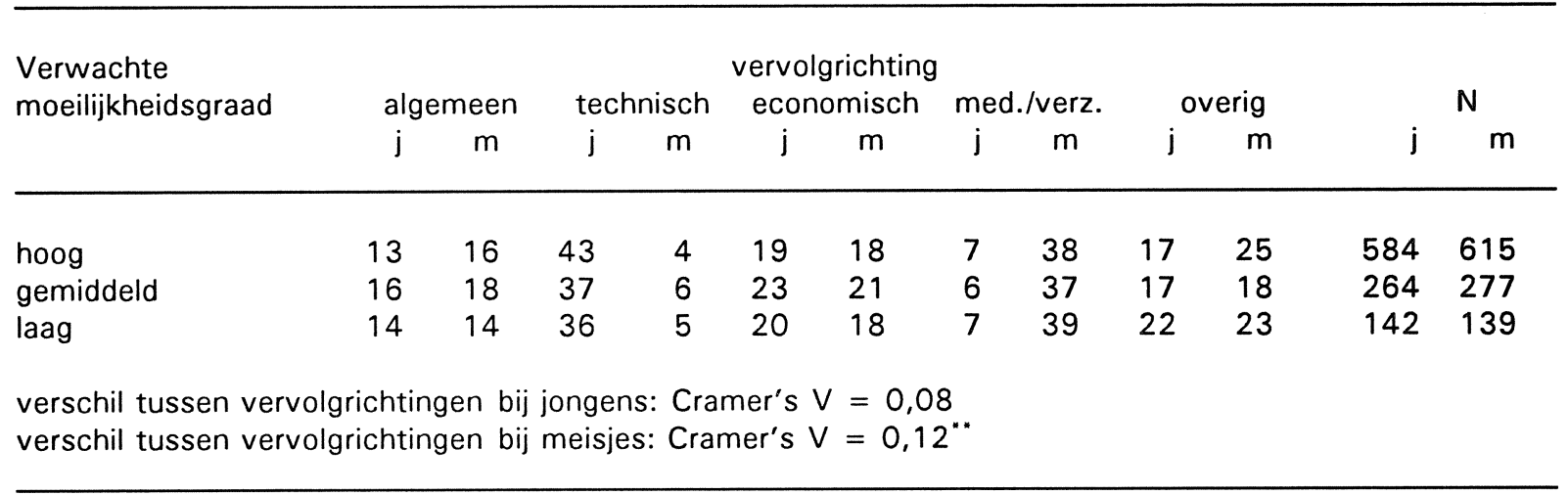

Tabel 11.12. geeft vervolgens een beeld van de relatie tussen de keuze-intentie en de verwachte relatieve arbeidsmarktpositie van het technisch onderwijs. Het blijkt dat van de leerlingen die een positief beeld van het technisch onderwijs hebben op het punt van de kans op werk of de kans op een hoog inkomen, verhoudingsgewijs vaak voor de technische richting kiezen. Daarbij lijkt het verband bij meisjes zwakker te zijn dan bij jongens.

Tabel 11.12. De keuze voor verschillende vervolgrichtingen naar geslacht en de verwachte arbeidsmarktpositie van technisch opgeleiden (rijpercentages per geslacht)

Imago $\quad \begin{aligned} & \text { algemeen } \\ & \text { j }\end{aligned}$

Kans op werk

$\begin{array}{lllllllllllll}\text { klein } & 19 & 17 & 17 & 4 & 28 & 18 & 10 & 43 & 25 & 18 & 190 & 491 \\ \text { gemiddeld } & 15 & 15 & 29 & 5 & 32 & 17 & 8 & 37 & 16 & 25 & 224 & 260 \\ \text { groot } & 12 & 15 & 52 & 7 & 14 & 22 & 5 & 26 & 17 & 30 & 577 & 279\end{array}$

verschil tussen vervolgrichtingen bij jongens: Cramer's $V=0,23^{* *}$

verschil tussen vervolgrichtingen bij meisjes: Cramer's $V=0,13^{* *}$

Inkomen

$\begin{array}{lllllllllllll}\text { laag } & 14 & 16 & 26 & 2 & 26 & 18 & 9 & 47 & 24 & 16 & 230 & 387 \\ \text { gemiddeld } & 15 & 16 & 37 & 5 & 22 & 19 & 7 & 37 & 19 & 22 & 386 & 374 \\ \text { hoog } & 14 & 16 & 51 & 8 & 16 & 18 & 5 & 24 & 14 & 34 & 378 & 272\end{array}$

verschil tussen vervolgrichtingen bij jongens: Cramer's $V=0,15^{* *}$

verschil tussen vervolgrichtingen bij meisjes: Cramer's $V=0,17^{* *}$

* = significant $5 \%$-niveau; ${ }^{*}=$ significant $1 \%$-niveau 
Tabel 11.13. De keuze voor verschillende vervolgrichtingen naar geslacht en de verwachte kwalitatieve aspecten van het werk van technisch opgeleiden (rijpercentages per geslacht)

\begin{tabular}{|c|c|c|c|c|c|c|c|}
\hline \multirow{2}{*}{ Imago } & algemeen & technisch & $\begin{array}{l}\text { vervolgrichting } \\
\text { economisch }\end{array}$ & med./verz. & overig & \multicolumn{2}{|c|}{$\mathrm{N}$} \\
\hline & j m & j m & j m & $\mathrm{j} \quad \mathrm{m}$ & $\mathrm{j} \quad \mathrm{m}$ & j & $\mathrm{m}$ \\
\hline
\end{tabular}

\section{Zwaar werk}

$\begin{array}{lrlllllllllll}\text { grote kans } & 14 & 16 & 42 & 4 & 20 & 23 & 5 & 39 & 18 & 18 & 600 & 513 \\ \text { gemiddeld } & 17 & 15 & 36 & 5 & 22 & 16 & 7 & 38 & 17 & 26 & 258 & 369 \\ \text { kleine kans } & 11 & 18 & 37 & 7 & 22 & 11 & 11 & 33 & 19 & 31 & 139 & 155\end{array}$

verschil tussen vervolgrichtingen bij jongens: Cramer's $V=0,08$ verschil tussen vervolgrichtingen bij meisjes: Cramer's $V=0,12^{* *}$

\section{Stress}

$\begin{array}{lrrrrrrrrrrrr}\text { grote kans } & 8 & 18 & 39 & 3 & 22 & 18 & 10 & 40 & 20 & 21 & 211 & 221 \\ \text { gemiddeld } & 16 & 14 & 39 & 4 & 19 & 21 & 6 & 44 & 21 & 17 & 400 & 415 \\ \text { kleine kans } & 15 & 17 & 42 & 6 & 21 & 18 & 6 & 29 & 15 & 29 & 384 & 397\end{array}$

verschil tussen vervolgrichtingen bij jongens: Cramer's $V=0,09$ verschil tussen vervolgrichtingen bij meisjes: Cramer's $V=0,13^{\text {"* }}$

\section{Vuil werk}

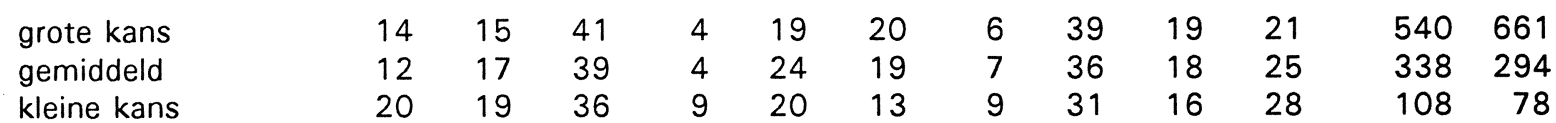

verschil tussen vervolgrichtingen bij jongens: Cramer's $V=0,08$ verschil tussen vervolgrichtingen bij meisjes: Cramer's $V=0,08$

\section{Saai werk}

$\begin{array}{lrrrrrrrrrrrr}\text { grote kans } & 17 & 15 & 21 & 1 & 27 & 18 & 11 & 42 & 23 & 23 & 235 & 533 \\ \text { gemiddeld } & 20 & 15 & 30 & 5 & 22 & 18 & 9 & 40 & 19 & 20 & 307 & 328 \\ \text { kleine kans } & 9 & 21 & 56 & 13 & 15 & 23 & 3 & 19 & 16 & 25 & 446 & 173\end{array}$

verschil tussen vervolgrichtingen bij jongens: Cramer's $V=0,23^{* *}$ verschil tussen vervolgrichtingen bij meisjes: Cramer's $V=0,18^{* *}$

\section{Zelfstandigheid}

$\begin{array}{lrrrrrrrrrrrr}\text { kleine kans } & 16 & 14 & 30 & 3 & 27 & 20 & 8 & 46 & 18 & 17 & 343 & 492 \\ \text { gemiddeld } & 17 & 19 & 35 & 4 & 21 & 19 & 5 & 34 & 22 & 26 & 319 & 365 \\ \text { grote kans } & 9 & 17 & 55 & 10 & 13 & 15 & 6 & 25 & 16 & 33 & 328 & 173\end{array}$

verschil tussen vervolgrichtingen bij jongens: Cramer's $V=0,17^{* *}$ verschil tussen vervolgrichtingen bij meisjes: Cramer's $V=0,17^{* *}$

* = significant $5 \%$-niveau; * $=$ significant $1 \%$-niveau 
De relatie tussen de keuze voor de verschillende vervolgrichtingen en het imago van het technisch onderwijs op het punt van de kwalitatieve aspecten van het werk is weergegeven in tabel 11.13. Van de vijf opgenomen aspecten blijken er met name twee van belang te zijn voor de keuze voor de technische richting. Van de leerlingen die denken dat technisch opgeleiden relatief vaak saai werk doen, kiezen er naar verhouding weinig voor de technische richting. Naarmate het beeld dat de leerlingen op dit punt van het technisch onderwijs hebben echter positiever wordt, neemt het percentage dat kiest voor de technische richting sterk toe. Vooral de belangstelling voor de medisch/verzorgende richting is kleiner onder de leerlingen die verwachten dat het werk van technisch opgeleiden niet saai is. Jongens kiezen daarnaast in verhouding minder vaak voor de economisch-administratieve richting. Daarnaast blijkt het aandeel leerlingen dat voor techniek kiest groter te zijn, naarmate men positiever denkt over de mate van zelfstandigheid die technisch opgeleiden in hun werk hebben. Ook hier blijkt dat de belangstelling voor de medisch/verzorgende richting geringer wordt en dat bovendien minder leerlingen voor de economische vervolgrichting kiezen.

Bij meisjes is er bovendien een zwak verband tussen de keuze-intentie en het beeld dat men heeft met betrekking tot de kans op lichamelijk zwaar werk en de kans op een beroep met veel stress. Bij de jongens wordt een dergelijk verband niet waargenomen. Voor zowel jongens als meisjes is er geen significant verband tussen de keuze voor de onderscheiden vervolgrichtingen en de gepercipieerde kans op vuil werk.

\section{Multivariate analyse}

De hierboven beschreven partiële analyses geven een eerste inzicht in de relatie tussen de keuze voor techniek en aantal persoons-, omgevings- en andere kenmerken en de houding van de leerlingen ten aanzien van technologische ontwikkeling en het imago van het technisch onderwijs. Door middel van een integrale analyse, waarbij alle relevante variabelen in een modelvergelijking ${ }^{9}$ worden opgenomen, kan beter worden nagegaan welke factoren dominant zijn in de verklaring van de keuze voor de technische richting. Omdat het percentage leerlingen van het $V B O-T e c h n i e k$ dat een technisch beroep of een technische vervolgopleiding kiest vrij groot is, en het aandeel VBO-Overig-leerlingen dat de technische richting in slaat juist vrij klein is, zijn beide opleidingscategorieën niet in de multivariate analyses opgenomen. Vanwege schattingstechnische redenen is bovendien geen apart model opgesteld voor het MAVO enerzijds en het HAVO/VWO anderzijds. Wel is een variabele in het model opgenomen om een mogelijk verschil tussen MAVO-ers en HAVO/VWO-ers in beeld te kunnen brengen.

Uit de in tabel 11.14. gepresenteerde schattingsresultaten komen twee relaties heel duidelijk naar voren. In de eerste plaats is de belangstelling van meisjes voor de technische richting significant (veel) kleiner dan de intentie van jongens om de techniek in te gaan. In de tweede plaats blijkt dat - niet verrassend - de keuze voor techniek sterk samenhangt met de interesse

9. Daartoe wordt gebruikt gemaakt van een zogenaamd probit keuzemodel. Zie bijvoorbeeld Amemiya (1981). 
Tabel 11.14. Schattingsresultaten van een multivariate analyse van de keuze voor de technische richting door MAVO- en HAVO/VWO-leerlingen (probitmodel; standaardfouten tussen haakjes)

Onafhankelijke

variabele

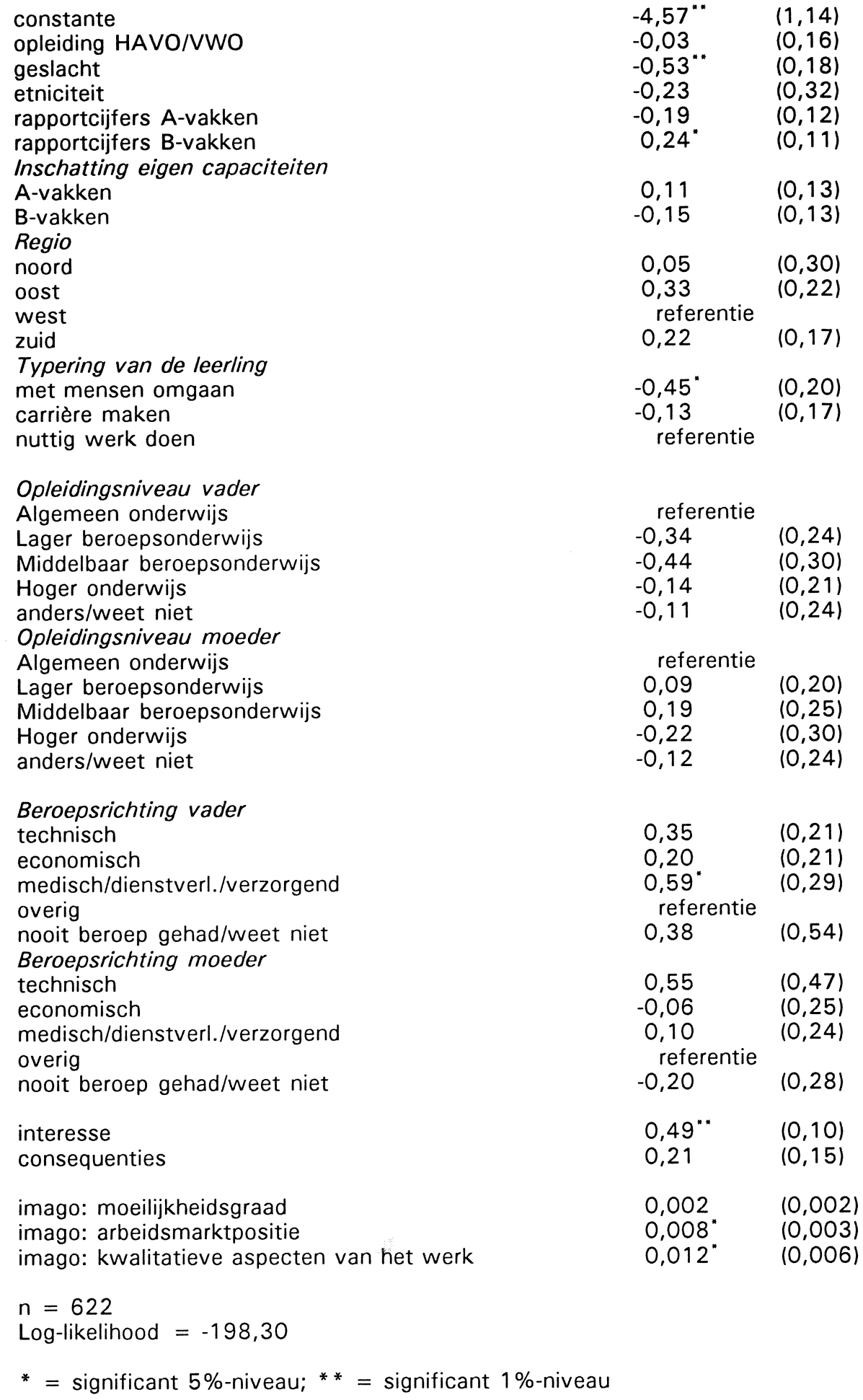


van de leerlingen voor technische onderwerpen ${ }^{10}$. Daarnaast wordt geconstateerd dat het beeld dat de jongeren van de arbeidsmarktpositie van technisch opgeleiden hebben van significant positieve invloed is op de keuze voor de technische richting. Het effect van deze factor is echter gering. Ook het beeld dat de leerlingen hebben van de kwalitatieve aspecten van het werk is significant gerelateerd aan de keuze-intentie voor de technische richting. Op grond van de in tabel 11.13. gepresenteerde resultaten is het aannemelijk dat vooral de kans op saai werk en de kans op een in redelijke zelfstandigheid uit te oefenen functie een belangrijke rol spelen. Verder blijkt dat de leerlingen met hoge cijfers voor de B-vakken vaker voor de technische richting willen kiezen. Leerlingen die met mensen omgaan het belangrijkste vinden voor hun eigen toekomst, kiezen daarentegen minder vaak voor een technische opleiding of een technisch beroep.

De conclusie bij de tabel kan luiden dat het al dan niet kiezen voor de technische richting vooral te maken heeft met interesse en dat er weinig andere directe knelpunten zijn die deze keuze belemmeren. Vooral meisjes later het afweten als het op techniek aankomt ${ }^{11}$. Ook bij de verklarende analyses van de interesse voor techniek is gebleken dat het geslacht een belangrijke factor is. Aspecten als het imago van het technisch onderwijs spelen wel een rol bij de keuze voor de technische richting, maar lijken vooralsnog minder belangrijk.

10. Ook Van Heugten (1993) concludeert dat de interesse de belangrijkste factor is ten aanzien van het al dan niet kiezen voor de technische richting.

11. De resultaten van aparte multivariate analyses voor jongens en meisjes laten een vergelijkbaar beeld zien als gepresenteerd in tabel 11.14 . 


\section{DE KEUZE VOOR TECHNIEK IN VOGELVLUCHT}

In dit vierde deel van het rapport is nader ingegaan op de gemaakte en de nog te maken richtingkeuzes van de leerlingen van het voortgezet onderwijs. Daarbij zijn de volgende drie keuzemomenten onderscheiden:

- de keuze na het basisonderwijs;

- de vakkenpakketkeuze in het algemeen voortgezet onderwijs;

- de keuze na de huidige opleiding.

De keuze voor de technische richting kan derhalve worden beschreven in termen van een trechter: bij elke keuzemoment wordt de doorvoer naar de techniek geringer. Vooral bij meisjes is het uiteinde van de trechter erg smal. In figuur 12.1. is dit weergegeven. Figuur 12.2. gaat daarbij verder in op de stromen die er naar de techniek zijn.

De trechter naar techniek begint bij de basisschool waar het potentieel voor de technische richting in theorie nog $100 \%$ bedraagt $^{12}$. Bij het eerste keuzemoment aan het einde van de basisschool wordt op 12-jarige leeftijd het potentieel voor de technische richting beperkt tot $91 \%$ van alle jongens en $76 \%$ van de meisjes. Van de jongens kiest namelijk $9 \%$ voor het VBOOverig en van de meisjes blijkt $24 \%$ hiervoor te kiezen ${ }^{13}$. Relatief vaak geven de meisjes aan dat zij deze opleiding (mede) zijn gaan volgen op advies van de basisschool. Overigens blijkt dat VBO-leerlingen de docenten van de basisschool verhoudingsgewijs weinig zien als informatiebron voor opleidingen in het voortgezet onderwijs, hetgeen er op zou kunnen wijzen dat het $\mathrm{VBO}$ in het basisonderwijs relatief weinig aandacht krijgt.

De leerlingen van het AVO moeten aan het einde van het derde of vierde leerjaar, dat wil zeggen op 15- à 16-jarige leeftijd, hun vakkenpakket samenstellen. Bij dit keuzemoment treedt derhalve een tweede vernauwing van de trechter op. Van de jongens kiest $39 \%$ een sterk op de techniek georiënteerd vakkenpakket. Bij de meisjes is dit slechts $18 \%$. Een belangrijk criterium om B-vakken wel of juist niet te kiezen is de mening deze vakken al dan niet nodig te hebben voor de vervolgopleiding of het beroep dat men voor ogen heeft. Door de vakkenpakketkeuze in het AVO staat in totaal voor circa de helft van alle jongens de keuze voor techniek nog open, terwijl bij de meisjes slechts ongeveer een zesde van alle uitstromers van het basisonderwijs overblijft voor de technische richting.

Het belangrijkste aandachtspunt in dit deel van het rapport betreft de 'uiteindelijke' keuze voor techniek na de huidige opleiding. Van de mannelijke VBO-Techniek-leerlingen wil bijna $80 \%$ later verder gaan in de technische richting. Slechts ongeveer $20 \%$ van de meisjes die deze opleiding volgen blijkt uiteindelijk voor de techniek te kiezen. Dit lage percentage hangt waarschijnlijk samen met het feit dat meisjes op het VBO-Techniek relatief vaak kiezen voor richtingen als

12. Natuurlijk kunnen kinderen van de basisschool al wel (enige) voorkeur voor een bepaalde richting hebben ontwikkeld.

13. Volledigheidshalve moet worden opgemerkt dat van de VBO-Overig-leerlingen uiteindelijk nog een klein gedeelte in de techniek terecht komt (zie ook figuur 12.2.). 


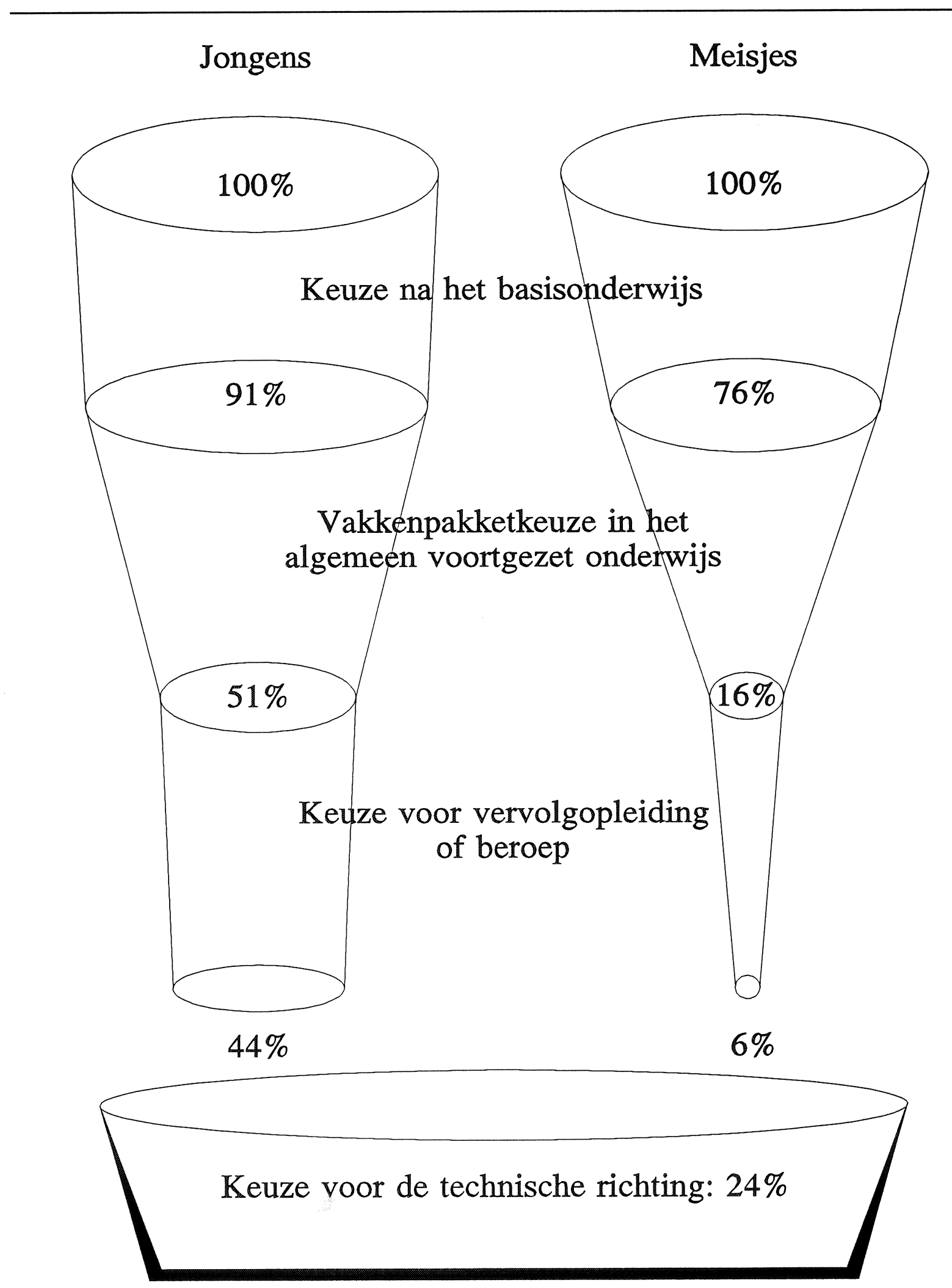


consumptieve techniek.

Zoals mocht worden verwacht, is de belangstelling voor de technische richting onder VBOOverig-leerlingen vrij gering. Ongeveer $15 \%$ van de jongens die deze opleiding volgen, wil verder gaan in de techniek. Dit heeft vooral betrekking op leerlingen die vanuit het lager agrarisch onderwijs doorstromen naar de technische richting. De keuze voor techniek door meisjes van het VBO-Overig is vrijwel nihil.

Van de jongens op het MAVO kiest bijna $40 \%$ voor de technische richting ${ }^{14}$. Ook bij deze opleidingscategorie blijkt de belangstelling voor de techniek onder meisjes zeer gering te zijn. Nog geen $5 \%$ geeft aan deze richting in te willen. Bij het HAVO/VWO wil ruim $30 \%$ van de jongens en circa $7 \%$ van de meisjes een vervolgopleiding in de technische richting kiezen.

De doorstroom vanuit het AVO naar de technische richting kan nog nader worden belicht. Uit figuur 12.2. blijkt dat van de leerlingen die een sterk op de exacte richting georiënteerd vakkenpakket (willen) kiezen slechts circa $40 \%$ doorstroomt naar de technische richting. Daarbij kan worden aangetekend dat vooral de doorstroom van meisjes erg klein is. De grootste concurrentie wordt hier gevormd door beroepen en opleidingen in de medische of verzorgende sfeer. Verder kan worden opgemerkt dat de stroom naar de techniek van leerlingen die niet het profiel 'Natuur en techniek' hebben gekozen gering is.

Totaal gezien komt slechts $24 \%$ van alle jongeren uiteindelijk in de technische richting terecht. Bij de jongens is de stroom naar de techniek met $44 \%$ redelijk groot. Door alle vernauwingen van de trechter blijkt echter maar $6 \%$ van de meisjes naar de technische richting door te stromen. Daarbij moet bovendien worden opgemerkt dat in de figuren ten onrechte wordt aangenomen dat alle technisch opgeleiden in een technisch beroep op de arbeidsmarkt terecht komen. In de praktijk blijkt namelijk dat er nogal eens sprake is van een doorstroom naar andere beroepsgroepen (zie bijvoorbeeld ROA, 1992a en Berendsen, De Grip en Willems, 1991).

In dit deel deze studie is ook een relatie gelegd tussen de keuze voor techniek en een aantal 'kenmerken' van de leerlingen. Het blijkt dat de jongens, waarvan de vader een algemeen voortgezette, dan wel een universitaire opleiding heeft gevolgd, relatief minder vaak voor de technische richting kiezen. Bij meisjes is van een dergelijke relatie geen sprake. Wel laten de enquêteresultaten zien dat meisjes, waarvan de moeder een HAVO/VWO-, HBO- of universitaire opleiding heeft gevolgd, verhoudingsgewijs minder vaak de medisch/verzorgende richting op willen gaan en iets vaker voor de techniek kiezen.

Ten aanzien van de relatie tussen de keuze voor de technische richting en de beroepsrichting van de ouders blijkt er nog steeds bij nogal wat jongeren een duidelijke 'zo vader, zo zoon'-, danwel 'zo moeder, zo dochter'-relatie te bestaan. Jongens waarvan de vader een technisch

14. Bij de figuren 11.1. en 11.2. zijn de leerlingen die van het MAVO naar het HAVO of van het HAVO naar het VWO willen gaan buiten beschouwing gebleven. 


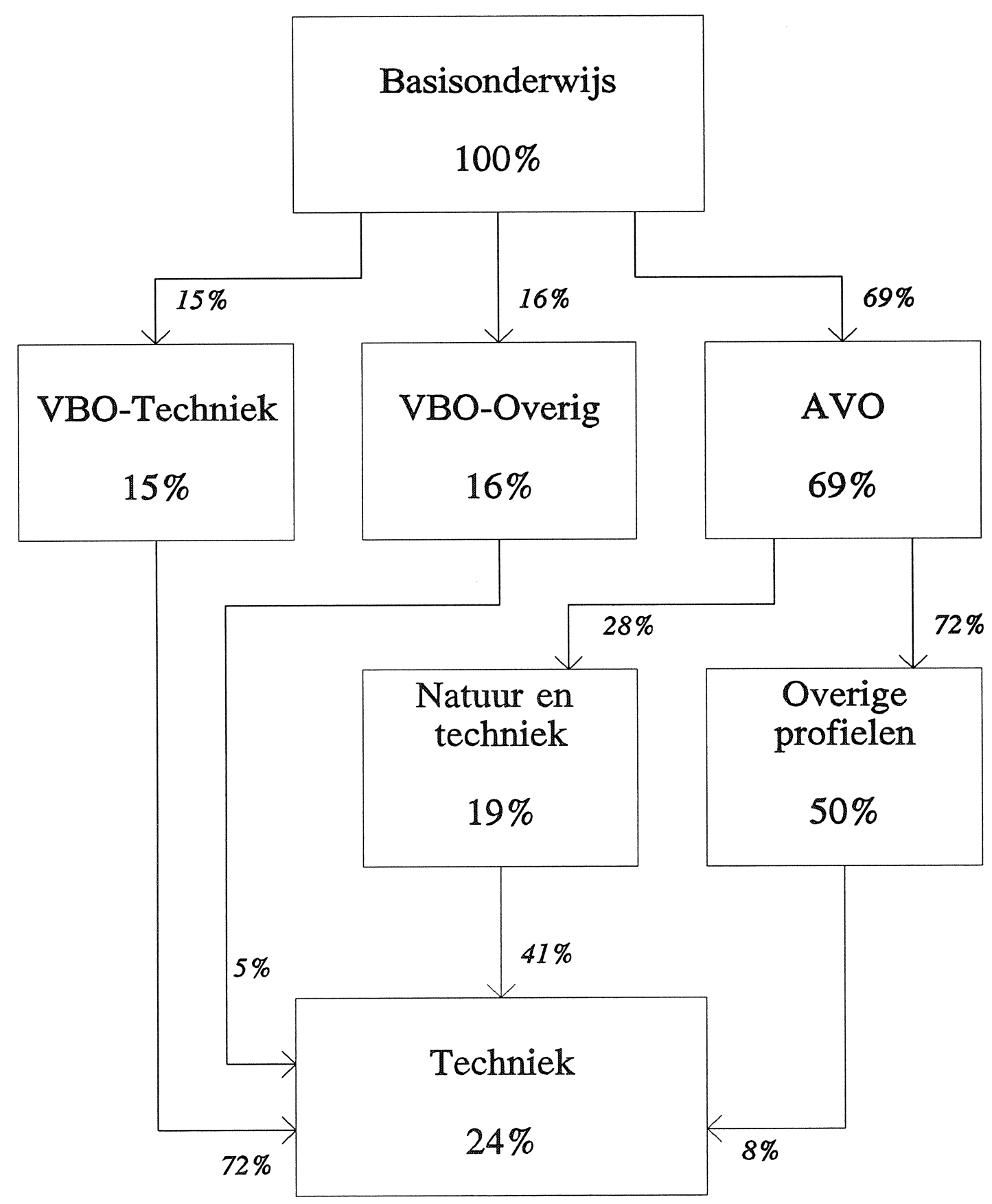


beroep heeft, kiezen zelf ook relatief vaak voor deze richting. Ook geldt dat de dochters van moeders met een technisch beroep relatief vaak voor de technische richting kiezen, al moet daarbij worden opgemerkt dat het aantal meisjes, waarvan de moeder in de technische richting werkzaam is (geweest) erg klein is.

Voorts blijkt dat de leerlingen die aangeven graag met mensen om te gaan een relatief grotere voorkeur hebben voor de medisch/verzorgende richting. De leerlingen die een goede carrière erg belangrijk vinden kiezen vaker voor de economische richting, terwijl degenen die vooral nuttig werk willen doen, meer belangstelling hebben voor de technische richting.

De rapportcijfers voor de A-vakken blijken nauwelijks gerelateerd te zijn aan de keuze voor bepaalde vervolgrichtingen. De cijfers voor de B-vakken zijn echter sterk selecterend bij de keuze voor de technische richting. De meningen van de leerlingen zelf over hun capaciteiten voor A- en B-vakken zijn eveneens in sterke mate bepalend voor hun vervolgkeuze. Opvallend is echter dat er een groot verschil bestaat tussen jongens en meisjes met betrekking tot het zichzelf goed of juist niet goed vinden voor een bepaald vak. Dit speelt met name bij de Bvakken. Aan de ene kant blijkt dat jongens met gemiddeld een laag cijfer voor de B-vakken veel minder vaak dan meisjes vinden dat zij slecht zijn in deze vakken, terwijl aan de andere kant meisjes met hoge cijfers voor de B-vakken vaker dan jongens van zichzelf vinden dat zij niet goed in deze vakken zijn.

Ook is nagegaan of er een verband bestaat tussen de keuze-intentie voor de technische richting en de beide andere 'monitoring-indicatoren' (waardering van techniek en imago van het technisch onderwijs), die respectievelijk in de delen II en III van dit rapport aan de orde zijn geweest. Bij de waardering voor techniek is daarbij een onderscheid gemaakt tussen de interesse voor techniek en de houding ten opzichte van de mogelijke economische en andere maatschappelijke gevolgen van de technologische ontwikkeling. Er blijkt een duidelijke relatie te bestaan tussen de interesse voor techniek en de keuze voor de technische richting. Opmerkelijk is echter dat van de meisjes die veel interesse in techniek hebben, slechts $20 \%$ voor de technische richting wil kiezen. Verder blijkt dat jongens die positiever denken over de consequenties van de technologische vernieuwing relatief vaak kiezen voor de technische richting. Overigens is het niet duidelijk hoe de causaliteit van dit verband ligt.

Het imago van het technisch onderwijs kan worden opgesplitst in drie verschillende elementen: de moeilijkheidsgraad van de opleiding, de arbeidsmarktpositie (de kans op werk en de hoogte van het inkomen) en de kwalitatieve aspecten van het werk. Vooral bij de laatste twee componenten is er sprake van een duidelijke relatie met de keuze voor techniek. Jongeren die de arbeidsmarktpositie van technisch opgeleiden relatief gunstig inschatten, kiezen vaker voor een beroep of opleiding in de technische richting. Ook het beeld dat men heeft van de kwaliteit van de arbeid van technisch opgeleiden is van invloed op de keuze voor de technische richting. Met name de verwachte kans op saai werk en de ingeschatte kans op een baan met veel zelfstandigheid zijn gerelateerd aan de keuze-intentie voor de technische richting. 
Wanneer deze bovengenoemde univariate verbanden worden samengebracht in een multivariaat model, dan blijkt echter dat de keuze voor techniek in belangrijke mate wordt bepaald door slechts twee kenmerken van de leerling ${ }^{15}$ : het geslacht en de interesse voor technische onderwerpen. Ook gaat er een positief effect uit van het imago van het technisch onderwijs op de keuze voor techniek. De omvang van dit effect is echter klein.

15. Daarbij wordt opgemerkt dat dit model alleen betrekking heeft op de AVO-leerlingen. 


\section{DEEL V}

BESLUIT 


\section{SAMENVATTING EN BELEIDSIMPLICATIES}

Het beschikbare 'menselijk kapitaal' en meer in bijzonder het innovatiepotentieel van de (beroeps)bevolking wordt dikwijls beschouwd als een noodzakelijke randvoorwaarde voor een positieve ontwikkeling van de nationale economie. Dit betekent dat er voldoende belangstellenden moeten zijn voor het technisch onderwijs en het werken in een technisch beroep. Daarnaast is een positieve publiekshouding ten aanzien van wetenschap en techniek van belang voor het creëren van een voldoende breed maatschappelijk draagvlak voor technologische vernieuwingen. In dit rapport is nagegaan hoe groot dit maatschappelijk draagvlak momenteel is. Daarbij is het onderzoek toegespitst op de jongeren van circa 14 à 15 jaar oud. Concreet zijn drie elementen van het maatschappelijk draagvlak aan de orde geweest:

- de waardering voor techniek;

- het imago van het technisch onderwijs;

- de keuze voor techniek.

Met betrekking tot de waardering voor techniek zijn drie facetten onderscheiden, te weten de interesse voor techniek, de houding ten opzichte van de mogelijke economische en andere maatschappelijke consequenties van technologische ontwikkelingen en de houding ten opzichte van de rol van meisjes in de technische richting. Daarbij is ook nagegaan of er een verschil bestaat tussen de waardering voor techniek in het algemeen en de waardering voor enkele specifieke technologieën.

Het blijkt dat jongens in het algemeen een vrij grote interesse in technische onderwerpen hebben. Daarentegen geven veel meisjes aan dat zij nauwelijks in techniek zijn geïnteresseerd. Dit beeld geldt voor vrijwel elke opleidingscategorie, waarbij wel kan worden opgemerkt dat, zoals mocht worden verwacht, de interesse voor techniek iets groter is bij de VBO-Techniekleerlingen en iets lager bij de leerlingen van het VBO-Overig.

De jongeren hebben in het algemeen een vrij positief beeld van de maatschappelijke consequenties van technologische vernieuwing, al is er bij meisjes sprake van een wat minder positieve houding dan bij jongens. Meisjes schatten met name de sociale gevolgen negatiever in. Zij hebben echter doorgaans wel een positief beeld van de invloed van de technologische ontwikkeling op de economische groei.

Vrijwel alle leerlingen staan positief tegenover de rol van vrouwen in de techniek. Daarbij zijn jongens toch iets minder positief dan meisjes, al is het verschil niet groot. Wel opmerkelijk is de duidelijk negatievere houding die de leerlingen uit etnische minderheidsgroepen aannemen ten opzichte van meisjes en techniek.

Behalve de waardering voor techniek in algemene zin, is ook de waardering voor enkele specifieke technologieën in beeld gebracht. Daarbij zijn achtereenvolgens onderscheiden: nieuwe apparaten, informatietechnologie, kernenergie en milieutechnologie. Deze technologieën worden door de jongeren - met uitzondering van kernenergie - vrij gunstig gewaardeerd. Vooral het 
economische belang van deze 'moderne' technologieën wordt door de leerlingen positief gewaardeerd. Het is bovendien opvallend dat de interesse voor deze specifieke vormen van technologie groter is dan de interesse voor techniek in het algemeen.

Het tweede facet van het maatschappelijk draagvlak voor technologische vernieuwingen dat in dit rapport in beeld is gebracht, is het imago van het technisch onderwijs. Achtereenvolgens is daarbij ingegaan op de verwachte moeilijkheidsgraad van de opleiding, de verwachte arbeidsmarktpositie van technici en het beeld dat de leerlingen hebben van enkele kwalitatieve aspecten van het werk van technisch opgeleiden. Hierbij is telkens gekeken naar de positionering van het technisch onderwijs ten opzichte van andere 'concurrerende' opleidingsrichtingen op hetzelfde niveau.

Het technisch onderwijs heeft bij de jongeren het imago van een moeilijke opleiding. Met name de leerlingen van het HAVO/VWO verwachten dat een studie in de technische richting relatief moeilijk is. Bij meisjes is dit beeld nog sterker dan bij jongens. Ook leerlingen van etnische minderheidsgroepen denken relatief vaak dat technisch onderwijs moeilijk is in verhouding tot de andere opleidingsrichtingen.

De leerlingen hebben daarentegen een vrij positief beeld van de arbeidsmarktpositie van technisch opgeleiden. Hun kans op werk wordt relatief erg groot geacht, terwijl men ook positieve verwachtingen heeft over de relatieve inkomenspositie van technisch opgeleiden. Bij meisjes is het beeld dat men heeft van de arbeidsmarktpositie overigens minder positief dan bij jongens. Ook de VBO-Overig-leerlingen zijn op beide punten duidelijk negatiever dan de andere leerlingen.

Ten aanzien van de kwalitatieve aspecten van het werk van technisch opgeleiden kan worden opgemerkt dat veel leerlingen op deze punten een vrij 'traditioneel' beeld hebben. Het werk van technisch opgeleiden is volgens hen in vergelijking met het werkveld van degenen met een andere opleiding zwaar, waarbij men bovendien verwacht dat technisch opgeleiden regelmatig vuil werk moeten doen. Daarentegen verwacht men dat de psychische belasting van het werk van technisch opgeleiden gering is. Ook acht men de kans op saai werk in vergelijking met de andere opleidingscategorieën niet groot, terwijl voor technisch opgeleiden bovendien een redelijke mate van zelfstandigheid in het werk wordt verwacht. Overigens moet bij deze laatste twee aspecten van de kwaliteit van het werk worden opgemerkt dat meisjes op deze punten een duidelijk negatiever beeld hebben van het werk van technisch opgeleiden dan jongens. Ook blijkt dat jongeren die behoren tot een etnische minderheidsgroep een negatiever beeld hebben van de kwalitatieve aspecten van het werk van technisch opgeleiden dan autochtone leerlingen.

Het beeld dat de leerlingen hebben van de kwantitatieve arbeidsmarktpositie en de kwaliteit van de arbeid van technisch opgeleiden is ook afgezet tegen de beschikbare meer feitelijke gegevens hierover. Geconcludeerd kan worden dat de leerlingen in het algemeen redelijk goed op de hoogte zijn van de gunstige arbeidsmarktpositie die technisch opgeleiden momenteel hebben. Daarentegen is het beeld dat men heeft van de kwalitatieve aspecten van het werk van 
technisch opgeleiden niet geheel juist. De leerlingen blijken hier in het algemeen een te negatief beeld van te hebben. Vooral het beeld dat technisch opgeleiden relatief vaak een fysiek zware baan hebben strookt niet geheel met de werkelijkheid. Ook op een aantal andere punten is het beeld dat de leerlingen van het technisch onderwijs hebben iets te negatief. Zo denken HAVOen VWO-leerlingen ten onrechte dat hoger en universitair opgeleiden relatief vaak vuil werk doen. Ook de kans dat men regelmatig saai werk moet doen, wordt vooral voor hoger technisch opgeleiden te negatief ingeschat. Dit is met name bij meisjes het geval, al moet daarbij de kanttekening worden geplaatst dat deze meisjes mogelijk een andere visie hebben op wat saai werk is dan degenen die in een technisch beroep werkzaam zijn. Het werkveld van medisch opgeleiden wordt daartegen met betrekking tot de saaiheid van het werk te positief ingeschat. Een belangrijke constatering is waarschijnlijk ook dat veel leerlingen ten onrechte denken dat economisch opgeleiden meer zelfstandigheid in hun werk hebben dan technisch opgeleiden.

Het derde aspect van het maatschappelijk draagvlak voor technologische vernieuwing dat is onderzocht, is de keuze-intentie voor de technische richting. Dit keuzeproces is in dit rapport beschreven als een trechtermodel, waarbij op drie plaatsen een al dan niet grote vernauwing optreedt van het aanbod van jongeren voor werk in de technische richting. De eerste vernauwing vindt plaats aan het einde van de basisschool. Een klein gedeelte van de jongens en een vrij groot deel van de meisjes kiest op 12-jarige leeftijd voor niet-technisch voorbereidend beroepsonderwijs. De tweede vernauwing van de trechter betreft de keuze van het vakkenpakket die de leerlingen van het $A V O$ op circa 15-jarige leeftijd moeten maken. Veel leerlingen grijpen die mogelijkheid aan om één of meer exacte vakken te laten 'vallen'. Tot slot vindt aan het einde van het voortgezet onderwijs de derde vernauwing van de trechter plaats. Op 16- tot 18-jarige leeftijd maken de leerlingen hun min of meer 'uiteindelijke' keuze voor een al dan niet technisch beroep of technische studie. De onderzoeksresultaten laten zien dat in totaal nog geen kwart van alle leerlingen voor de technische richting denkt te gaan kiezen. Zeker bij meisjes is het uiteinde van de trechter erg nauw: amper $5 \%$ is van plan verder te gaan in de technische richting.

Uit de uitgevoerde analyses naar de mogelijke factoren die de keuze voor de technische richting verklaren, kan een aantal relaties worden afgeleid. Zo blijkt er bijvoorbeeld een 'zo vader, zo zoon'-effect te bestaan: jongens waarvan de vader een technisch beroep uitoefent, kiezen vaker voor de technische richting. Ook is het al dan niet kiezen van de technische richting sterk gerelateerd aan de cijfers die de leerlingen voor de B-vakken halen. Verder blijkt dat de studieof beroepskeuze van de leerlingen samenhangt met het beeld dat men heeft van de arbeidsmarktpositie en de kwaliteit van de arbeid van technisch opgeleiden.

Wanneer echter in een meer samenhangend verband naar de mogelijke verklaringsgronden voor het al dan niet kiezen voor de technische richting wordt gekeken, dan blijkt dat twee factoren hierbij een cruciale rol spelen: het geslacht en de interesse voor techniek in het algemeen. Bovendien blijkt er een (zwak) positief verband te bestaan tussen de arbeidsmarktverwachtingen voor technisch opgeleiden en de keuze-intentie voor de technische richting. Daarbij kan worden opgemerkt dat de twee belangrijkste factoren sterk aan elkaar zijn gerelateerd. Ook andere 
persoons- of omgevingskenmerken, zoals bijvoorbeeld de beroepsrichting van de ouders of de rapportcijfers voor de B-vakken, zullen waarschijnlijk in meerdere of mindere mate doorwerken in hun interesse in techniek en derhalve indirect van invloed zijn op het keuzegedrag van de leerlingen. Daarnaast bestaat er een vrij duidelijke relatie tussen de interesse van de leerlingen voor techniek en het beeld dat zij van de arbeidsmarktpositie en het werkveld van technisch opgeleiden hebben.

De belangrijkste conclusie van het onderzoek op dit punt is dat voor het verkrijgen van een groter potentieel voor de technische richting vooral de belangstelling onder meisjes dient te worden vergroot. Om een beter inzicht te krijgen in de betekenis van wijzigingen in het keuzegedrag van meisjes zullen de implicaties daarvan in beeld worden gebracht. Daarbij wordt eerst ingegaan op de drie in het trechtermodel beschreven keuzemomenten. Vervolgens worden enkele specifieke doelgroepen gedefinieerd van waaruit meer belangstellenden voor de technische richting zouden kunnen worden gerecruteerd.

Het eerste 'uitvalmoment' van meisjes betreft de keuze na het basisonderwijs voor een opleiding binnen het VBO-Overig. Momenteel kiest $24 \%$ van de meisjes voor een van deze opleidingsrichtingen. Wanneer dit percentage met $5 \%$-punt zou kunnen worden teruggebracht ten gunste van het VBO-Techniek dan betekent dit dat, uitgaande van het huidige aantal leerlingen, jaarlijks ongeveer 1.000 extra technisch opgeleide vrouwen op de arbeidsmarkt terecht zullen komen, onder de veronderstelling dat de overige keuzeverhoudingen niet veranderen ('ceteris paribus'). Dit komt overeen met een toename van de 'uiteindelijke' keuze voor techniek met $2 \%$ van het huidige totaal aantal kiezers voor de technische richting, hetgeen neerkomt op een totale groei van de keuze voor techniek met nauwelijks 0,5\%-punt.

Het tweede uitvalmoment treedt, zoals gezegd, op bij de vakkenpakketkeuze in het voortgezet onderwijs. Slechts $18 \%$ van de meisjes van het AVO kiest voor het doorstroomprofiel 'Natuur en techniek'. Als dit percentage met $5 \%$-punt zou kunnen worden opgehoogd, terwijl in het overige keuzegedrag niets verandert, komt dit bij het huidige aantal leerlingen neer op uiteindelijk ruim 750 extra belangstellenden voor de techniek.

Het uiteinde van de trechter naar techniek is bij meisjes zo nauw dat slechts $6 \%$ van de meisjes uiteindelijk in de technische richting terecht komt. Wanneer dit percentage met $5 \%$-punt zou kunnen worden verhoogd, levert dit vanzelfsprekend het grootste aantal extra belangstellenden voor de technische richting op. Bij het huidige leerlingenaantal komt dit neer op een jaarlijks extra aanbod van circa 5.000 technisch opgeleiden. Ten opzichte van het huidige aantal leerlingen dat uiteindelijk voor de technische richting kiest, is dit een toename van ongeveer $10 \%$.

Bovenstaande 'scenario's' geven een indruk van het kwantitatieve effect van op zich niet al te rigoureuze aanpassingen in het keuzegedrag van meisjes. Ze geven echter geen goed beeld van wat op dit punt op middellange-termijn enigszins realistische beleidsdoelstellingen zouden kunnen zijn. Bovendien zullen met name de gewenste veranderingen die optreden in de 
richtingkeuze na het basisonderwijs en de vakkenpakketkeuze in het voortgezet onderwijs, ook al zouden deze veranderingen relatief snel kunnen worden bewerkstelligd, slechts op de langere termijn kunnen doorwerken in het aanbod van technisch opgeleiden. Het is derhalve realistischer om na te gaan wat het kwantitatieve effect is van een veranderend keuzegedrag van specifieke doelgroepen die reeds meer affiniteit met de technische richting hebben.

Een eerste doelgroep is wat dit betreft de groep meisjes van het AVO die gemiddeld een 7 heeft voor de B-vakken. Hiervan kiest slechts $9 \%$ (direct) voor de technische richting, terwijl dit bij de jongens $32 \%$ is. Wanneer zou kunnen worden bewerkstelligd dat een doelstelling van een gelijk keuzegedrag van jongens en meisjes op dit punt voor de helft wordt bereikt, dat wil zeggen dat $16 \%$ van de meisjes van het AVO met gemiddeld een 7 voor de B-vakken voor de technische richting zou kiezen, dan zullen bij het huidige leerlingenaantal en onder de veronderstelling dat de overige keuzepatronen niet veranderen circa 2.000 mensen additioneel voor de technische richting beschikbaar komen. Het totaal aantal leerlingen dat voor de technische richting kiest zal daardoor met $4 \%$ stijgen.

De tweede doelgroep die hier expliciet wordt genoemd, betreft de leerlingen die het profiel 'Natuur en techniek' hebben gekozen. Van deze leerlingen - zowel jongens als meisjes - kiest slechts $41 \%$ uiteindelijk voor de technische richting. De belangrijkste 'concurrentie' van andere opleidingsrichtingen is hierbij afkomstig van de medisch/verzorgende richting, op ruime afstand gevolgd door de economische richting. Als het percentage dat voor techniek kiest met $5 \%$-punt zou kunnen worden verhoogd tot $46 \%$, levert dit eveneens jaarlijks circa 2.000 extra technisch opgeleiden op. Bij elkaar levert een veranderd keuzegedrag van deze beide laatstgenoemde potentiële doelgroepen - gecorrigeerd voor dubbeltellingen - op middellange-termijn mogelijk een extra aanbod van technisch opgeleiden van jaarlijks ongeveer 3.000 leerlingen. Dit komt neer op een toename van $6 \%$.

In tabel 13.1. zijn de kwantitatieve effecten van de op middellange-termijn enigszins realistische veranderingen in het keuzegedrag van de leerlingen op de 'uiteindelijke' keuze voor de technische richting nog eens op een rijtje gezet. Hieruit kan worden afgeleid dat de resultaten van een beleid dat is gericht op het stimuleren van de studie- en beroepskeuze in de technische richting naar alle waarschijnlijkheid slechts beperkt zullen zijn. Daarbij moet bovendien worden beseft dat het al een hele opgave zal zijn om de hierboven geformuleerde doelstellingen te realiseren. Dit temeer daar blijkt dat de keuze voor de technische richting slechts in beperkte mate wordt beïnvloed door de gevolgen van een onterecht negatief imago van de arbeidsmarktpositie en de kwalitatieve aspecten van het werk van technisch opgeleiden. Op dit punt biedt vrijwel alleen de onterechte beeldvorming ten aanzien van de fysieke belasting in technische beroepen en - vooral ten aanzien van de hogere technische beroepen - de mate waarin vuil werk moet worden verricht een concreet aanknopingspunt voor voorlichtingscampagnes e.d. Daarnaast zou kunnen worden gedacht aan specifiek op allochtone jongeren gerichte voorlichting en curriculumontwikkeling, met name gericht op het werken van meisjes in de techniek en de moeilijkheidsgraad van het technisch onderwijs. 
Tabel 13.1. Implicaties van veranderingen in het keuzegedrag met betrekking tot de technische richting

toename 'uiteindelijk' aanbod technisch opgeleiden

Na de basisschool:

- $\quad 5 \%$-punt meer meisjes gaan naar VBO-

Techniek in plaats van naar VBO-Overig

Vakkenpakketkeuze in het voortgezet onderwijs:

- $\quad 5 \%$-punt meer meisjes kiezen voor profiel 'Natuur en techniek'

Keuze na het voorgezet onderwijs:

- $\quad 5 \%$-punt meer meisjes kiezen voor de technische richting

Specifieke doelgroepen

- $\quad 16 \%$ in plaats van $9 \%$ van de meisjes van het AVO met gemiddeld minstens een 7 voor de B-vakken kiest voor de technische richting

- $\quad 46 \%$ in plaats van $41 \%$ van de AVOleerlingen met het profiel 'Natuur en techniek' kiezen voor de technische richting 2.000

- Combinatie van beide voorgaande veranderingen

Dit brengt ons tot de conclusie dat, wanneer het beleid zich tot doel stelt dat, gezien de internationale concurrentiepositie van de Nederlandse economie, het potentieel aan technisch opgeleiden moet worden vergroot, dit vraagt om een 'brede aanpak', waarbij de verschillende actoren allemaal hun steentje zullen moeten bijdragen ${ }^{1}$. Enkele mogelijke elementen van een dergelijk wellicht toekomstig te voeren beleid zullen hieronder nader worden aangegeven.

Zoals reeds eerder is opgemerkt, is een belangrijke conclusie van het onderzoek dat één van de cruciale knelpunten ten aanzien van de keuze voor de technische richting de te geringe interesse voor techniek is. Dit maakt dat het versterken van het technisch potentieel van de Nederlandse samenleving zowel wat betreft het aantal technisch opgeleiden, als ook het maatschappelijk draagvlak voor technologische ontwikkelingen in het algemeen, slechts op basis van een langetermijn beleid kan worden bewerkstelligd. Een concreet aanknopingspunt voor het vergroten van de interesse van jongeren voor techniek is de positieve houding van jongeren ten opzichte van bepaalde moderne technologieën. Hierop zou in de curriculumontwikkeling wellicht beter kunnen worden ingespeeld. Daarnaast is het van belang dat het techniekonderwijs voor de leerlingen toegankelijk en herkenbaar is. Het zou dichter moeten staan bij de eigen belevingswereld van de

1. Men zou in dit verband kunnen spreken van een Deltaplan. Een beeldspraak die hier mede op zijn plaats is daar de deltawerken bij uitstek kunnen worden gezien als een symbool voor het technisch potentieel van ons land. 
leerlingen. Mogelijk dat in het kader van een 'thematische aanpak' het techniekonderwijs in meerdere of mindere mate zou kunnen worden geïntegreerd in andere vakken. Daarbij geldt dat dit alles reeds zou moeten plaatsvinden op een zo jong mogelijke leeftijd. Ofschoon de invoering van het vak techniek in de per 1 augustus 1993 ingaande basisvorming in het voortgezet onderwijs in principe kan worden gezien als een goede stap in deze richting, is het echter noodzakelijk om ook reeds in het basisonderwijs kinderen meer met techniek vertrouwd te maken $^{2}$. Daarbij is het van groot belang dat dit techniekonderwijs ook binnen de dagelijkse belevingswereld van meisjes past.

Bij een dergelijk lange-termijn beleid is echter niet alleen een rol weggelegd voor de overheid en het onderwijsveld. Minstens even belangrijk is de bijdrage die het bedrijfsleven zou moeten leveren aan het vergroten van de interesse voor de technische richting. Daarbij kan bijvoorbeeld wordt gedacht aan bedrijfsbezoeken van jonge kinderen. Daarnaast mag van het bedrijfsleven worden verwacht dat zij bijdraagt aan het wegnemen van het negatieve imago van het werk van technisch opgeleiden bij met name meisjes. Bovendien zijn er vooral op hoger niveau opleidingsrichtingen die financieel aantrekkelijker zijn dan de technische richting, zodat ook op het gebied van de beloning een taak voor het bedrijfsleven is weggelegd.

Eveneens is uit het onderzoek gebleken dat het technisch onderwijs in het algemeen als moeilijk wordt getypeerd. Ook hierop zouden de betrokken partijen een gericht beleid kunnen voeren. Het technisch onderwijs zou wellicht zorg kunnen dragen voor bepaalde onderwijskundige verbeteringen, waaronder een betere begeleiding van de leerlingen en studenten met studieproblemen, zodat deze minder snel buiten de boot vallen. De overheid zou kunnen denken aan het invoeren van (meer) positieve prikkels om voor de technische richting te kiezen. Voorbeelden hiervan zijn maatregelen ten aanzien van de lengte van de maximale studieduur of additionele voorzieningen in de sfeer van de studiefinanciering. Voor het bedrijfsleven kan eveneens een rol zijn weggelegd in de vorm van het bieden van goede (stage)faciliteiten aan de studenten of het aangaan van lange-termijn samenwerkingsprojecten met scholen.

Grootscheepse campagnes om de keuze voor de techniek te bevorderen, zoals die in het verleden zijn gevoerd (bijvoorbeeld Kies exact en Vrouwen gezocht voor mannenwerk) lijken al met al niet het geëigende middel om de gestelde doelstellingen te bereiken ${ }^{3}$. Een belangrijk nadeel van dergelijke grootscheepse campagnes is dat zij zijn gericht op jongeren die wellicht niet formeel, maar in feite al wel een keuze voor een bepaalde hoofdrichting hebben gemaakt of op zijn minst bepaalde richtingen reeds hebben uitgesloten. Wat dit betreft is het illustratief dat

2. Daarmee wordt reeds een begin gemaakt door middel van het 'Actieplan Techniek voor het basisonderwijs', dat door de Ministeries van Onderwijs en Wetenschappen en Economische Zaken is ontwikkeld. Een belangrijk element in dit plan is de aandacht voor het techniekonderwijs in de lerarenopleiding.

3. Van der Aa, Hofman en Latuheru (1990) vinden dat dergelijke campagnes wel leiden tot een grote naambekendheid van de technische richting, maar geven aan dat de invloed ervan beperkt is. Wel zouden deze campagnes een bevestiging kunnen geven van (waarschijnlijk) reeds gemaakte beroepsof opleidingskeuzes. 
er een groot verschil is tussen de positieve houding die de leerlingen tegenover het werken van vrouwen in de techniek aannemen en het geringe aantal meisjes dat daadwerkelijk voor een technische studie of technisch werk kiest. Het is derhalve beter om op dit punt een meer op specifieke doelgroepen gericht beleid te voeren. Daarbij kan men bijvoorbeeld denken aan de meisjes met hoge cijfers voor de B-vakken en de leerlingen die een exact vakkenpakket kiezen. Ook bij de leerlingen die behoren tot de etnische minderheidsgroepen lijkt, zoals gezegd, een latent potentieel voor de technische richting aanwezig te zijn.

Naast het voeren van een dergelijk breed gedragen beleid is het echter gewenst om de arbeidsmarktpositie van technisch opgeleiden voortdurend te 'monitoren'. Er zal scherp in de gaten moeten worden gehouden waar tekorten aan technici dreigen en waar mogelijk overschotten ontstaan. Anders dreigt immers het gevaar dat het momenteel goede imago dat het technisch onderwijs op het gebied van de arbeidsmarktpositie heeft, verloren gaat, mede als gevolg van de relatief grote conjunctuurgevoeligheid van de werkgelegenheid in veel technische beroepsgroepen (zie ROA, 1992a). Dit zou men enigszins kunnen vergelijken met de problematiek zoals die zich regelmatig in de zorgsector en op de arbeidsmarkt voor leerkrachten heeft voorgedaan. Als grote tekorten worden afgewisseld met grote overschotten, is het voor leerlingen lastig de arbeidsmarktpositie van een opleiding op de juiste waarde te schatten. Daarbij is het voorts van belang om de verschillende segmenten van de arbeidsmarkt voor technici apart te beschouwen. Uiteraard moet daarbij de blik waar mogelijk vooruit zijn gericht.

Het moge duidelijk zijn dat een dergelijk techniek-stimuleringsplan alleen kans van slagen heeft als alle drie onderscheiden actoren, de overheid, de onderwijsinstellingen en het bedrijfsleven hieraan deelnemen. Daarbij kan een onderscheid worden gemaakt tussen enerzijds een korte- of middellange-termijn beleid dat er op is gericht om de huidige en binnenkort te verwachten knelpunten op de arbeidsmarkt op te lossen en anderzijds een lange termijn-beleid dat ervoor moet zorgen dat er een structureel breder draagvlak ontstaat, zowel voor het technisch potentieel van de beroepsbevolking, als voor het maatschappelijk draagvlak voor technologische vernieuwing in het algemeen. 


\section{LITERATUUR}

Aa, R. van der, W.H.A. Hofman, E.J. Latuheru (1990), Perspectief in techniek, Rotterdams Instituut voor Sociologisch en Bestuurskundig Onderzoek, Rotterdam.

Allaart, P.C., R. Kunnen, W.C.M. Praat, A.M. de Voogd-Hamelink, J.P.M. Vosse (1993), Trendrapport aanbod van arbeid 1993, OSA-rapport nr. 17, Den Haag.

Amemiya, T. (1981), Qualitative Response Models: A Survey, Journal of Economic Literature, jrg. 19, blz. 1483-1536.

Berendsen, H., A. de Grip, E.J.T.A. Willems (1991), De arbeidsmarkt voor onderzoekers 19902010, Beleidsstudies Technologie Economie no. 13, Ministerie van Economische Zaken, Den Haag.

Centraal Bureau voor de Statistiek (1987), Lonen en loonkosten, Sociaal-economische maandstatistiek, jrg. 4, no. 10, blz. 36-45.

Centraal Planbureau (1992), Nederland in drievoud; Een scenariostudie van de Nederlandse economie 1990-2015, SDU Uitgeverij, Den Haag.

Central Planning Bureau (1992), Scanning the Future; A Long-Term Scenario Study of the World Economy 1990-2015, SDU Publishers, The Hague.

Dijck, M. van (1991), Indirecte leerroutes tot het HBO, (in)efficiënte leerroutes?, Tijdschrift voor Hoger Onderwijs, blz. 162-172.

Gimbrère, M.C. (1992), Arbeidsmarktpositie van afgestudeerden van de Agrarische Hogescholen; Jaargang 1990, Stichting SHAO, Wageningen.

Heugten, J. van (1993), Vakkenpakketkeuze op het VWO; Attitudes tegenover een B-pakket en een technische studie, OCTO-report 93-01, Eindhoven.

Holland, C.A. (1992), Technologie en samenleving, in: J.W.A. van Dijk, L.G. Soete (red.), Technologie in een economie met open grenzen, Samsom, Alphen aan den Rijn/Zaventem, blz. 295-307.

Jong, U. de, H. Oosterbeek, J. Roeleveld, H.D. Webbink (1992), Verder studeren, voornemens van eindexamenkandidaten 1991; Een panelstudie onder scholieren en studenten, Ministerie van Onderwijs en Wetenschappen, Zoetermeer.

Klerk Wolters, F. de (1989), The Attitude of Pupils Towards Technology, proefschrift, Eindhoven.

Knulst, W., P. van Beek (1988), Publiek en techniek; opvattingen over technologische vernieuwingen, Sociaal en Cultureel Planbureau, Cahier nr. 57, Rijswijk.

Kodde, D.A., J.M.M. Ritzen (1986), Vraag naar hoger onderwijs. Eindrapport, Ministerie van Onderwijs en Wetenschappen, Serie beleidsgerichte studies Hoger Onderwijs en Wetenschappelijk Onderzoek nr. 6, Den Haag.

Loo, P.J.E. van de, G.W.M. Ramaekers, R.K.W. van der Velden (1992), HBO-Monitor 1991 (diverse sectorrapportages), Voorlichtingsdienst HBO-Raad, Den Haag. 
Ministerie van Economische Zaken (1990), Economie met open grenzen, Tweede Kamer, vergaderjaar 1989-1990, 21.670, nrs. 1-2, Den Haag.

Ministerie van Economische Zaken (1991), Technologie \& Samenleving, Hoofdlijnen notitie, Den Haag.

Ministerie van Landbouw, Natuurbeheer en Visserij (1992), Landbouwonderwijs in beeld/1991, Den Haag.

Ministerie van Onderwijs en Wetenschappen (1991), Profiel van de tweede fase voortgezet onderwijs, Zoetermeer.

Ministerie van Onderwijs en Wetenschappen (1992), Profiel van de tweede fase voortgezet onderwijs, vervolgnota, Zoetermeer.

Ministerie van Onderwijs en Wetenschappen, Ministerie van Economische Zaken (1991), TWIN, Technologie- en Wetenschapsindicatoren, Zoetermeer/Den Haag.

Mueller, D.J. (1986), Measuring Social Attitudes; A Handbook for Researchers and Practitioners, Teachers College Press, New York/London.

Researchcentrum voor Onderwijs en Arbeidsmarkt (1992a), De arbeidsmarkt naar opleiding en beroep tot 1994, ROA-R-1992/1, Maastricht.

Researchcentrum voor Onderwijs en Arbeidsmarkt (1992b), Statistische bijlage: De arbeidsmarkt naar opleiding en beroep tot 1994; Actualisering 1992, ROA-R-1992/8B, Maastricht.

Stijnen, F.H.H.C., M.H. Wieling (1988), Arbeidsmarktverwachting en arbeidsmarktpositie van LTS-ers; Verslag van een enquête onder eindexamenleerlingen en schoolverlaters van de Technische School Maastricht, Rijksuniversiteit Limburg, FdEW, ROA, Maastricht.

Wieling, M.H., P.J.E. van de Loo, R.K.W. van der Velden (1993a), Waar komen onze schoolverlaters terecht? De uitstroom en bestemming van het schooljaar 1990/1991, LDC, Leeuwarden.

Wieling, M.H., P.J.E. van de Loo, R.K.W. van der Velden (1993b), Waar komen de schoolverlaters van het middelbaar technisch onderwijs terecht? De uitstroom en bestemming van het schooljaar 1990/1991, LDC, Leeuwarden.

Willems, E.J.T.A., A. de Grip (1993), Jongeren en techniek; Studie- en beroepskeuzes, waardering en beeldvorming ten aanzien van techniek, Beleidsstudies Technologie Economie, Ministerie van Economische Zaken, Den Haag. 
BIJLAGE A

VRAGENLIJSTEN JEUGD EN TECHNIEK 



\title{
VRAGENLIJST JEUGD EN TECHNIEK 1992
}

\author{
VWO-4
}

\section{Let op:}

- Lees de vragen zorgvuldig door.

- Kruis een hokje aan of vul je antwoord in op de stippellijntjes.

- Er is telkens maar één antwoord mogelijk, tenzij anders aangegeven.

- S.v.p. een blauwe pen gebruiken (geen potlood of rode pen!).

Naam van de school:

Plaats: 


\section{Algemeen}

1. Wanneer ben je geboren?

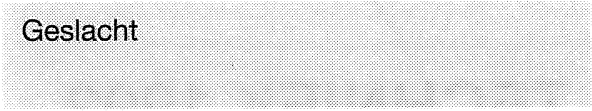

3. Tot welke etnische groep behoor je?

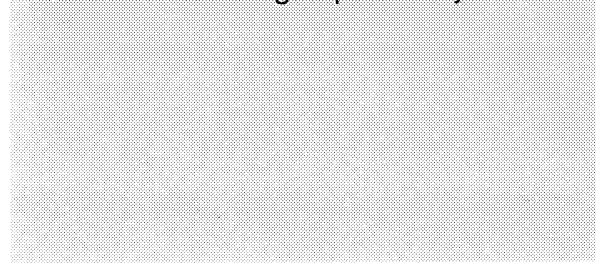

4. Vul de cijfers in die je aan het eind van de derde klas op je rapport had (afronden op hele cijfers).

Als je een vak niet gehad hebt, zet dan een streepje! jaar: 19

9-10

maand:

\begin{tabular}{|l|l}
\hline 1 & Nederlandse \\
\hline 2 & Surinaamse \\
\hline 3 & Antilliaanse \\
\hline 4 & Turkse \\
\hline 5 & Marokkaanse \\
\hline 6 & anders, namelijk \\
\hline
\end{tabular}

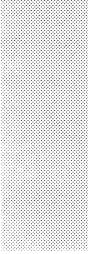

Nederlands

Frans

15

16

Duits

Engels

Geschiedenis/staatsinrichting Aardrijkskunde

Wiskunde

Natuurkunde

Scheikunde

Biologie

\section{Ouders}

5. Wat is de (hoogste) opleiding die je ouders/verzorgers hebben gevolgd?

Lager Onderwijs

MAVO, (M)ULO

HAVO, VWO, MMS, HBS, Gymnasium enz.

LBO

b.v. LTS, Ambachtsschool, LHNO, Huishoudschool, LEAO enz.

$\mathrm{MBO}$

b.v. MTS, MEAO, Verpleegkunde enz.

$\mathrm{HBO}$

b.v. HTS, HEAO, Pedagogische Academie enz.

Universiteit

een andere opleiding, namelijk weet ik echt niet moeder/verzorgster
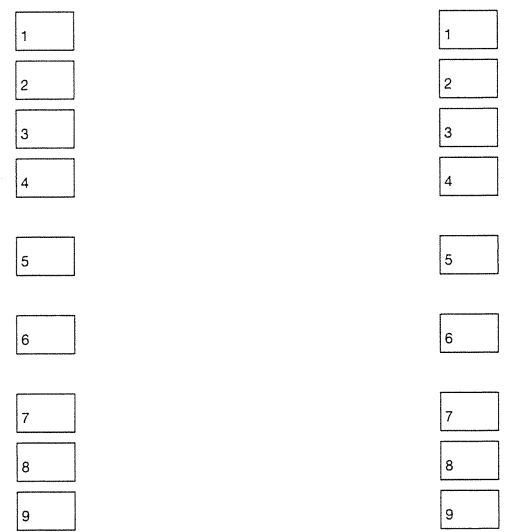
6. Welke van de onderstaande mogelijkheden is momenteel op je ouders/verzorgers van toepassing?

vader/verzorger

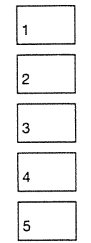

heeft betaald werk

is werkloos

is arbeidsongeschikt (WAO)

werkt uitsluitend in huishouden

anders, namelijk

7. Wat voor soort beroep hebben je ouders/verzorgers?

Als één van hen of beiden op dit moment geen betaald werk hebben, kruis dan het beroep aan dat hij/zij als laatste heeft uitgeoefend.

vader/verzorger

onderwijzend beroep

b.v. leraar, kleuterleidster enz.

agrarisch beroep

b.v. akkerbouwer, landbouwkundige, tuinder enz.

technisch beroep

b.v. elektricien, ingenieur, technisch tekenaar, operator enz.

transportberoep

b.v. chauffeur, piloot, schipper, conducteurenz.

medisch beroep

b.v. arts, verpleegkundige, fysiotherapeut enz.

economisch of administratief beroep

b.v. bankemployé, boekhouder, secretaresse, managerenz.

handelsberoep

b.v. winkelier, vertegenwoordiger, verkoperenz.

dienstverlenend beroep

b.v. kok, schoonmaker, bejaardenverzorger,

kapper, schoonheidsspecialistenz.

veiligheidsberoep

b.v. politieagent, brandweerman, beroepsmilitair enz

een ander beroep, namelijk

heeft nooit een beroep gehad

weet ik echt niet moeder/verzorgster

moeder/verzorgster
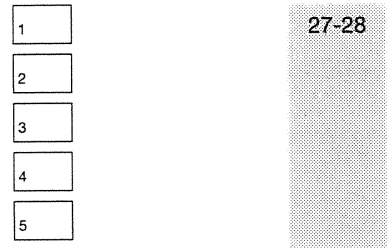

29-32
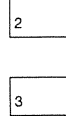

4

5
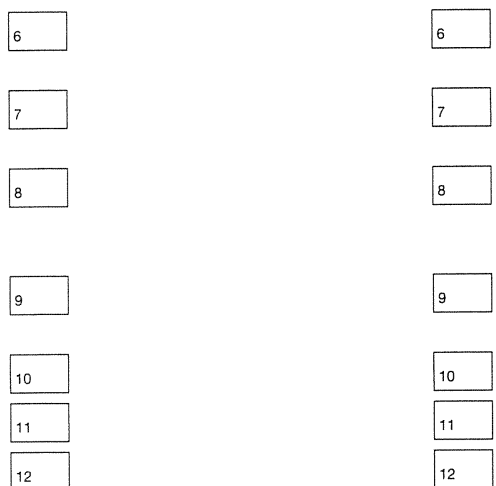

\section{Huidige opleiding}

8. Welke opleiding werd jou aan het eind van de basisschool geadviseerd?

\begin{tabular}{ll}
\hline 1 & LBO \\
\hline 2 & LBO/MAVO \\
\hline 3 & MAVO \\
\hline 4 & MAVO/HAVO \\
\hline 5 & HAVO \\
\hline 6 & HAVO/VWO \\
\hline 7 & VWO \\
8 & weet ik niet (meer)
\end{tabular}


9.

Waarom ben je naar de opleiding gegaan waarop je nu zit?

Hier mag je meer dan één antwoord aankruisen!

10. Hoe ben je te weten gekomen welke opleidingen je na de basisschool kon kiezen?

Hier mag je meer dan één antwoord aankruisen!

11a. Heb je er spijt van dat je naar de opleiding bent gegaan waarop je nu zit?

b. Welke opleiding had je dan liever gedaan?

12a. Geef van de volgende vakken aan of je van jezelf vindt dat je er goed of slecht in bent.
vakje 1 = erg goed
vakje 2 = goed
vakje $3=$ niet goed, niet slecht
vakje $4=$ slecht
vakje 5 = erg slecht

Frans

Geschiedenis

Wiskunde

Natuurkunde

b. Geef van deze vakken ook aan of je ze moeilijk of makkelijk vindt.

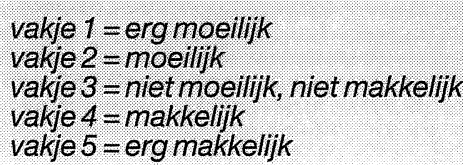

Frans

Geschiedenis

Wiskunde

Natuurkunde

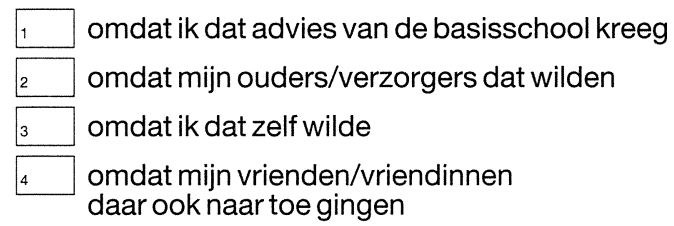

$5 \quad$ omdat deze opleiding nodig is voor de opleiding die ik hierna wil volgen

6 omdat deze opleiding nodig is voor het beroep dat ik later wil uitoefenen

$7 \quad$ om een andere reden, namelijk

1 door de onderwijzer(es) op de basisschool

+ ja $\rightarrow$ gaverder met vraag $11 b$
$2 \quad$ nee $\rightarrow$ gaverder met vraag 12

\begin{tabular}{|c|c|}
\hline 1 & lager agrarisch onderwijs (b.v. LAS) \\
\hline 2 & lager technisch onderwijs (b.v. LTS) \\
\hline 3 & lager economisch-administratief onderwijs (b.v. LEAO) \\
\hline 4 & lager dienstverlenend/verzorgend onderwijs (b.v. LHNO) \\
\hline 5 & MAVO \\
\hline 6 & HAVO \\
\hline & een andere opleiding, namelijk \\
\hline
\end{tabular}

erg

goed
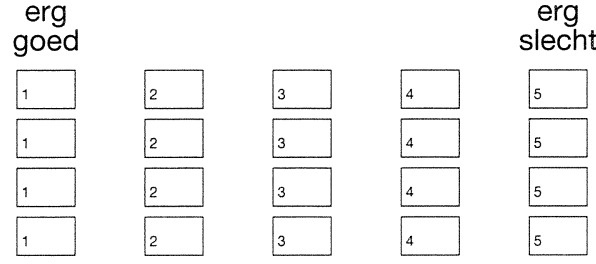

49

50

51

52 
13. Als je nu je vakkenpakket voor het eindexamen zou moeten kiezen, welke zeven vakken zou je dan kiezen?

Kruis zeven vakken aan! Bedenk hierbij dat je in ieder geval Nederlands en tenminste één van de talen Frans, Duits of Engels moet kiezen en dat je ten hoogste één expressievakmag kiezen.

Geschiedenis/staatsinrichting

Wiskunde A

Wiskunde $B$

Natuurkunde

Scheikunde

Biologie

Economie I

Economie II

Handvaardigheid I (handenarbeid)

Handvaardigheid II (textiele werkvormen)

Tekenen

Muziek

een ander vak, namelijk

14. Geef voor de genoemde vakken aan wat voor jou de belangrijkste redenen zijn om het wel of juist niet te kiezen.

Kruis voor ieder vak ten hoogste drie redenen aan!

Werk daarbij de vraag per vak af!

mijn cijfers voor dit vak

of ik dit vak leuk vind

of ik dit vak moeilijk of makkelijk vind

of mijn vrienden/vriendinnen

dit vak ook kiezen

of ik een leuke docent voor dit vak krijg

of ik dit vak nodig heb voor de vervolgopleiding die ik hierna wil volgen

of ik dit vak nodig heb voor het beroep dat ik wil uitoefenen

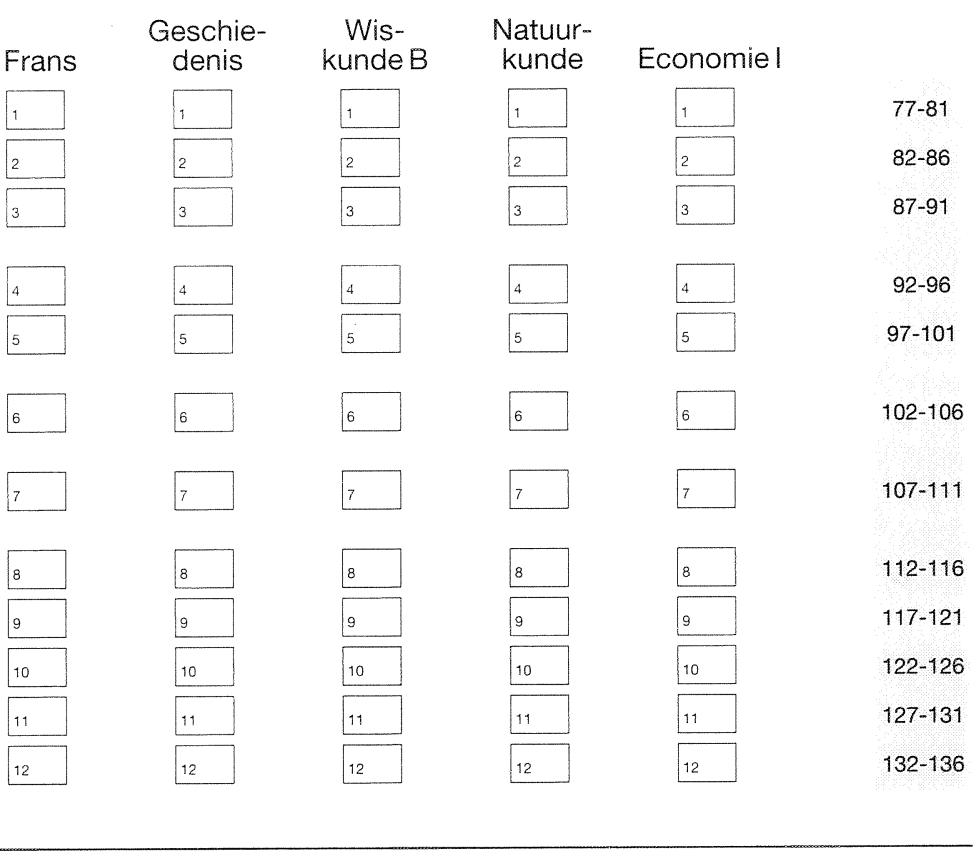

of dit vak past bij de andere vakken die ik denk te gaan kiezen

de mening van mijn ouders/verzorgers de mening van mijn vrienden/vriendinnen de mening van mijn docenten/dekaan andere redenen

rijg

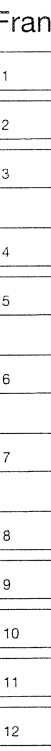

\section{Na deze opleiding}

15. Geef aan wat je het belangrijkste vindt .... met mensen omgaan 
16. Wat denk je na het behalen van het VWO-diploma te gaan doen?

Als je na het behalen van je einddiploma eerst in militaire dienst gaat, kruis dan aan wat je daarna denkt te gaan doen!

17. Waarom wil je na het VWO verder leren? Hier mag je meer dan één antwoord aankruisen!

18. Welke opleiding wil je dan gaan volgen? een part-time opleiding
140 b.v. PABO, Lerarenopleiding

2 agrarische opleiding in het $\mathrm{HBO}$ b.v. HAS, HTUS

3 technische of laboratoriumopleiding in het $\mathrm{HBO}$ b.v. HTS, HLO

4 medische opleiding in het $\mathrm{HBO}$ b.v. HBO-V, fysiotherapie

$5 \quad$ economische opleiding in het $\mathrm{HBO}$ b.v. HEAO

6 sociale opleiding in het $\mathrm{HBO}$ b.v. maatschappelijk werk, sociaal-pedagogische hulpverlening

$7 \quad$ kunstopleiding in het $\mathrm{HBO}$ b.v. Kunstacademie, Conservatorium, Toneelacademie

8 universitaire opleiding in de letteren b.v. talenstudies, geschiedenis

$9 \quad$ universitaire opleiding in de agrarische wetenschappen

10 universitaire opleiding in de technische wetenschappen b.v. wiskunde, natuurkunde

11 universitaire studie in de medische wetenschappen b.v. geneeskunde, tandheelkunde, diergeneeskunde

12 universitaire opleiding in de economische wetenschappen

13 universitaire opleiding in de rechten

14 universitaire opleiding in de sociale wetenschappen b.v. sociologie, psychologie

15 een andere opleiding, namelijk

Ga verder met vraag 22 
19. Waarom wil je na het WWO gaan werken?

Hier mag je meer dan één antwoord aankruisen!

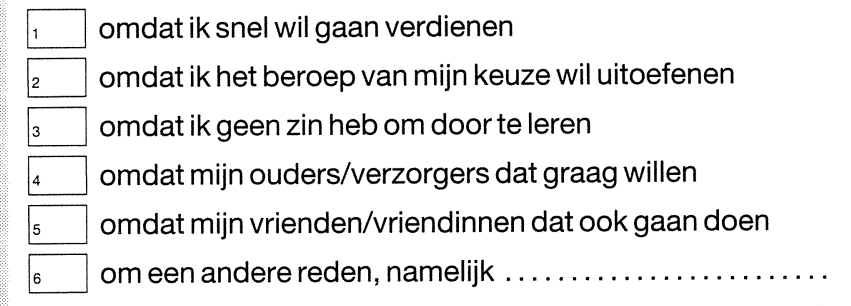

Ga verder met vraag 21

20. Waarom wil je na het $\mathrm{VWO}$ gaan werken gecombineerd met een part-time opleiding? Hiermagje meer dan één antwoord aankruisen!

21. Welk beroep wil je dan gaan uitoefenen?

\begin{tabular}{|c|c|}
\hline 1 & agrarisch beroep \\
\hline & 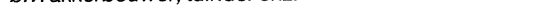 \\
\hline 2 & $\begin{array}{l}\text { technisch beroep } \\
\text { b.v. technisch tekenaar, operatorenz. }\end{array}$ \\
\hline 3 & transportberoep \\
\hline & o.v. criaumeur, scripper, comiductear enz. \\
\hline 4 & $\begin{array}{l}\text { medisch beroep } \\
\text { b.v. verpleegkundige, ziekenverzorgerenz. }\end{array}$ \\
\hline 5 & economisch-administratief beroep \\
\hline & b.v. accountant, boekhouder, secretaresse enz. \\
\hline 6 & handelsberoep \\
\hline 7 & dienstverlenend beroep \\
\hline & b.v. kok, kapper, schoonheidsspecialist enz. \\
\hline 8 & veiligheidsberoep \\
\hline 9 & een ander beroep, namelijk ......... \\
\hline
\end{tabular}

\section{Onderwijs en arbeidsmarkt}

22.
Bij de volgende vragen moet je een
volgorde aangeven. Geef daarbij telkens een nummering aan van 1 tot en met 7 .

\section{VOORBEELD}

Welke opleiding wordt volgens jou het meeste door meisjes gekozen?

$1=$ meeste
tot en met
$7=$ minste.
Als je denkt dat meisjes het vaakst Letteren kiezen, gevolgd door Sociale wetenschappen, Rechten, Economie, Medische wetenschappen, Technische wetenschappen en tenslotte Agrarische wetenschappen, vul je dit als volgt in:

\section{. 1. . Letteren}

(b.v. talenstudies, geschiedenis)

..7 .. Agrarische wetenschappen

..6 . . Technische wetenschappen (b.v. wiskunde, natuurkunde)

.. 4.. Economie

.. 3. . Rechten

..2. Sociale wetenschappen

..5 .. Medische wetenschappen 
a. Met welke opleiding heeft men volgens jou de grootste kans op werk?

1 grootste $k$ ans

toten met

$7=k l e i n s t e k a n s$

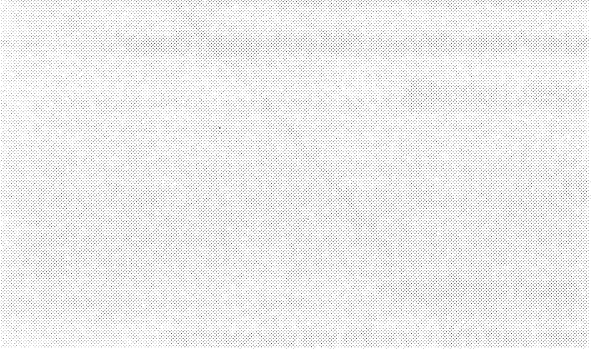

b. Met welke opleiding heeft men volgens jou de grootste kans een hoog inkomen te verdienen?

$1=$ grootste $k$ ans

tot en met

$7=$ kleinste $k a n s$.
Letteren

(b.v. talenstudies, geschiedenis)

Agrarische wetenschappen

Technische wetenschappen

(b.v. wiskunde, natuurkunde)

Economie

Rechten

Sociale wetenschappen

Medische wetenschappen

toten met

$7=$ kleinste $k a n s$ de grootste kans een beroep te krijgen dat veel spanningen ('stress') met zich meebrengt?

$1=$ groots
tot en met

$7=$ kleinste $k a n s$

Letteren

(b.v. talenstudies, geschiedenis)

Agrarische wetenschappen

Technische wetenschappen

(b.v. wiskunde, natuurkunde)

Economie

Rechten

175

(b.v. talenstudies, geschiedenis)

Agrarische wetenschappen (b.v. wiskunde, natuurkunde)

(b.v. talenstudies, geschiedenis)

Agrarische wetenschappen

Technische wetenschappen (b.v. wiskunde, natuurkunde)

1
3
7
4
7

78

79

80

Rechten

Sociale wetenschappen

Medische wetenschappen 
e. Met welke opleiding heeft men volgens jou de grootste kans een beroep te krijgen waarbij je vaak vuil werk moet doen?

$1=$ grootste $k$ ans

toten met

$7=k$ leinste $k$ ans
Letteren

(b.v. talenstudies, geschiedenis)

Agrarische wetenschappen

Technische wetenschappen

(b.v. wiskunde, natuurkunde)

Economie

Rechten

Sociale wetenschappen

Medische wetenschappen f. Met welke opleiding heeft men volgens jou de grootste kans een beroep te krijgen waarbij je vaak saai werk moet doen?

1 = grootste kans

tot en met

$7=$ kleinste kans.
Letteren

(b.v. talenstudies, geschiedenis)

Agrarische wetenschappen

Technische wetenschappen

(b.v. wiskunde, natuurkunde)

\section{Economie}

Rechten

Sociale wetenschappen

Medische wetenschappen g. Met welke opleiding heeft men volgens jou de grootste kans een beroep te krijgen waarin je veel dingen zelfstandig kunt regelen?

1 = grootste kans

tot en met

$7=$ kleinste kans.
Letteren

(b.v. talenstudies, geschiedenis)

Agrarische wetenschappen

Technische wetenschappen

(b.v. wiskunde, natuurkunde)

\section{Economie}

Rechten

Sociale wetenschappen

Medische wetenschappen h. Welke opleiding is volgens jou het moeilijkste?

$1=$ moeilijkste

toten met

$7=$ makkelijkste.
Letteren

(b.v. talenstudies, geschiedenis)

Agrarische wetenschappen

Technische wetenschappen

(b.v. wiskunde, natuurkunde)

\section{Economie}

Rechten

Sociale wetenschappen

Medische wetenschappen 


\section{Techniek}

23. Wat is jouw mening over de volgende beweringen?

vakje $1=$ helemaal eens

vakje 2 =eens

vakje $3=$ niet eens, niet oneens

vakje $4=$ oneens

vakje 5 = helemaal oneens

a. Techniek interesseert me niet.

b. Een meisje kan best een technisch beroep hebben.

c. Techniek is goed voor de toekomst van ons land.

d. Ik lees niet graag technische tijdschriften.

e. Techniek is niet belangrijk in het leven.

f. Door techniek wordt het leven ingewikkelder.

g. Als er een hobbyclub over techniek was, werd ik zeker lid.

helemaal

eens

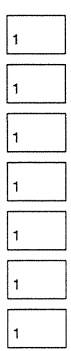

h. Omdat techniek vervuiling veroorzaakt, moeten we het minder gebruiken.

i. Door techniek gaat alles beter.

j. Erzouden meer televisieprogramma's over techniek moeten zijn.

k. Jongens zijn meer geschikt om technische dingen te doen dan meisjes.

I. Ik vind het leuk om thuis zelf iets te repareren.

m. Techniek veroorzaakt een hoge werkloosheid.

n. Jongens weten meer van techniek dan meisjes.

o. Techniek heeft meer goede dingen dan slechte dingen gebracht.

p. Techniek is goed voor de economie van ons land.

q. Er zouden meer meisjes in de techniek moeten werken.

r. De wereld zou er beter uitzien zonder techniek.

s. Als er iets nieuws is uitgevonden, wil ik er graag meer van weten.

t. I $\mathrm{k}$ vind dat we de wereld te snel laten veranderen door de techniek.
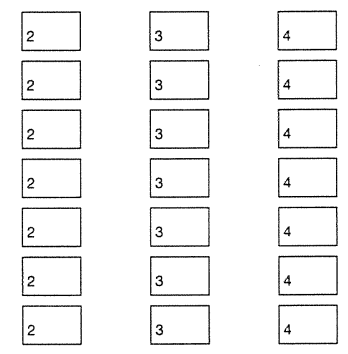

helemaal oneens
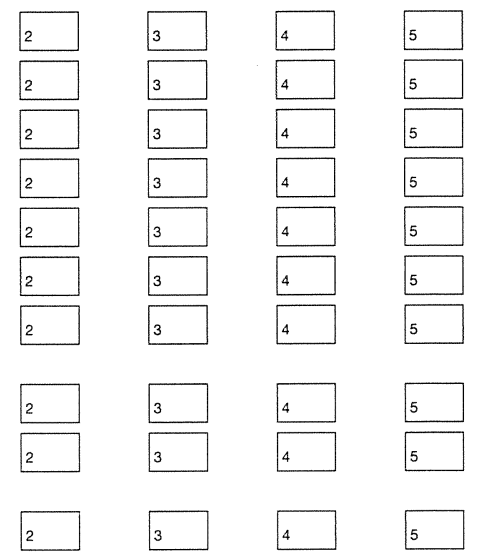

229
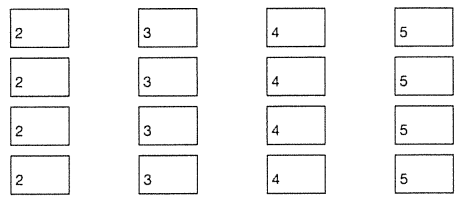

230

231

232

233

234

235

236

237

238

239

De volgende beweringen gaan over nieuwe apparaten. Daarbij kun je denken aan de CD-speler, magnetron-oven enz.
24a. Ik zou graag meer over nieuwe apparaten willen weten.
b. Nieuwe apparaten zijn goed voor de economie van ons land.
c. Nieuwe apparaten veroorzaken een hoge werkloosheid.
d. Nieuwe apparaten maken het leven niet aangenamer.
e. Nieuwe apparaten zijn al met al een goede zaak.

helemaal

eens
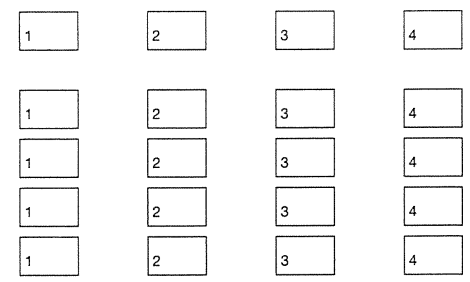

helemaal oneens

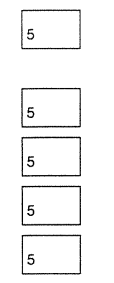


De volgende beweringen gaan over informatietechnologie (b.v. computers).

\section{helemaal \\ eens}

25a. Ik zou graag meer over informatietechnologie willen weten.

b. Informatietechnologie is goed voor de economie van ons land.

c. Informatietechnologie veroorzaakt een hoge werkloosheid.

d. Informatietechnologie maakt het leven onpersoonlijker.

e. Informatietechnologie is al met al een goede zaak.
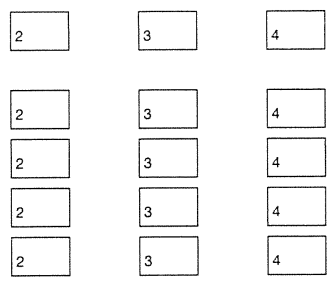

De volgende vragen gaan over kernenergie.

26. Heb je wel eens eerder gehoord van

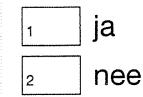
kernenergie?

nee

27.

Geef je mening over de volgende

beweringen.

helemaal

eens

a. Ik zou graag meer over kernenergie willen weten.

b. Kernenergie is goed voor de economie van ons land.

c. Kernenergie veroorzaakt een hoge werkloosheid.

d. Kernenergie is slecht voor het milieu.

e. Kernenergie is al met al een goede zaak.
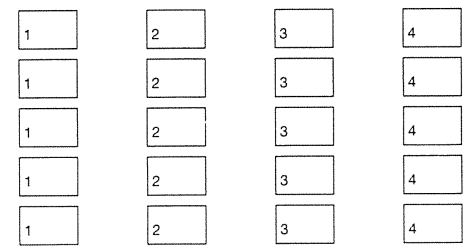

helemaal oneens

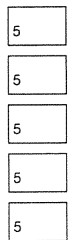

Nu komen enkele vragen over milieutechnologie.

28. Hebje wel eens eerder gehoord van milieutechnologie?

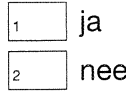

29. Geef ook je mening over de volgende beweringen.

helemaal eens

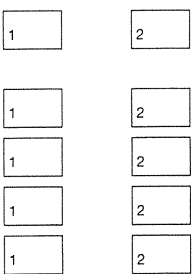

helemaal oneens

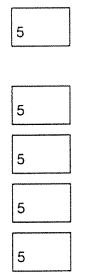

257

258 259 260 261 


\section{Opmerkingen}

Ruimte voor opmerkingen:

Hartelijk dank voor het invullen. 
BIJLAGE B

BETROUWBAARHEID VAN DE TECHNIEK-WAARDERINGSSCHALEN 
Zoals reeds aangegeven in hoofdstuk 3 van dit rapport, wordt voor het meten van de drie elementen van de waardering voor techniek l'interesse', 'consequenties van techniek' en 'meisjes en techniek') nauw aangesloten bij het instrument dat (mede) is ontwikkeld door De Klerk Wolters (1989). Dit heeft als belangrijk voordeel dat van een reeds gevalideerd instrument gebruik wordt gemaakt, zodat in dit onderzoek het ontwikkelen van valide schalen niet meer nodig is.

De drie techniek-waarderingsschalen zijn alle van het Likert-type. Een dergelijke Likert-schaal bestaat uit een aantal items over een bepaald onderwerp, waarover de respondenten hun mening moeten geven, variërend van 'helemaal eens' tot 'helemaal oneens' (5-puntsschaal). In hoofdstuk 3 van dit rapport zijn drie schalen uit het onderzoek van De Klerk Wolters gekozen. Daarbij moet wel worden aangetekend dat het aantal items gezien de lengte van onze vragenlijst enigszins moest worden beperkt. In deze bijlage zal worden nagegaan of deze qua aantal items beperkte schalen voldoende betrouwbaar zijn ${ }^{4}$.

Tabel B.1. Gemiddelde, standaarddeviatie en item-rest-correlatie per item

Item

gemiddelde standaard- item-restdeviatie correlatie

\section{Interesse}

Techniek interesseert me niet Ik lees niet graag technische tijdschriften

Als er een hobbyclub over techniek was, werd ik zeker lid

Er zouden meer televisieprogramma's over techniek moeten zijn

Ik vind het leuk om thuis zelf iets te repareren

Als er iets nieuws is uitgevonden, wil ik er graag meer van weten

$\begin{array}{lll}3,08 & 1,49 & 0,65 \\ 2,39 & 1,40 & 0,56 \\ 2,00 & 1,14 & 0,63 \\ 2,70 & 1,19 & 0,62 \\ 3,28 & 1,36 & 0,58 \\ 3,38 & 1,18 & 0,49\end{array}$

\section{Consequenties}

Techniek is goed voor de toekomst van ons land

Techniek is niet belangrijk in het leven

Door techniek wordt het leven ingewikkelder

Omdat techniek vervuiling veroorzaakt, moeten we het minder gebruiken3,18

Techniek veroorzaakt een hoge werkloosheid

Techniek heeft meer goede dingen dan slechte dingen gebracht

Techniek is goed voor de economie van ons land

Meisjes en techniek

Een meisje kan best een technisch beroep hebben Jongens zijn meer geschikt om technische dingen te doen dan meisjes Jongens weten meer van techniek dan meisjes Er zouden meer meisjes in de techniek moeten werken

4,60
3,66
3,49
3,69

4,60

0,83

1,32

0,35

1,31

0,55

0,47

0,99

4. Zie voor een handboek over het meten van attitudes, het ontwikkelen van schalen en het toetsen van de betrouwbaarheid ervan Mueller (1986). 
Tabel B.1. geeft per item de gemiddelde score, de standaarddeviatie en de item-rest-correlatie of R-waarden weer ${ }^{5}$. Deze R-waarden hebben betrekking op de correlatie tussen de score van een bepaald item en de totale score van alle andere items van de desbetreffende schaal. De tabel laat zien dat voor de meeste items de standaarddeviatie van de scores groter zijn dan 1, hetgeen algemeen wordt beschouwd als een minimumgrens voor de item-gevoeligheid. Alleen bij de items 'Een meisjes kan best een technisch beroep hebben' en 'Techniek is goed voor de economie van ons land' is de standaarddeviatie van de score duidelijk lager dan 1. De item-restcorrelaties zijn voor vrijwel alle items vrij hoog, hetgeen wil zeggen dat de afzonderlijke items hetzelfde meten als de gehele schaal. Dit geldt voor alle items, waarbij kan worden opgemerkt dat voor de items van de schaal 'consequenties van techniek' de laagste waarden worden waargenomen.

Tot slot wordt in tabel B.2. gekeken naar Cronbach's $a$, als maat voor de homogeniteit van de schaal. De interesseschaal met een Cronbach's $a$ van 0,82 blijkt een goede schaal te zijn. Voor de beide andere schalen blijkt dat de homogeniteit van de schalen eveneens groter is dan 0,60 , hetgeen wordt gezien als minimumeis voor (zwak) homogene schalen.

Tabel B.2. Cronbach's a voor de verschillende schalen

Schaal Cronbach's $a$

\begin{tabular}{ll} 
Interesse & 0,82 \\
Consequenties & 0,63 \\
Meisjes en techniek & 0,64 \\
\hline
\end{tabular}

Uit de bovenstaande analyses kan worden geconcludeerd dat de drie techniek-waarderingsschalen, die in dit onderzoek a priori zijn onderscheiden, voldoende betrouwbaar zijn. Op grond van de hierboven beschreven toetsen hoeft geen van de items uit een schaal te worden verwijderd. Hoewel door het beperken van het aantal items de schalen ten opzichte van de resultaten van De Klerk Wolters iets zwakker zijn geworden, zijn de verschillen vrij gering. De drie schalen kunnen derhalve in dit onderzoek worden gehanteerd.

5. De scores van negatief geformuleerde items zijn eerst 'gespiegeld'. 
BIJLAGE C

OVERZICHT VAN GEBRUIKTE VARIABELEN

IN DE MULTIVARIATE ANALYSES 
Tabel C.1. Overzicht van gebruikte variabelen in de multivariate analyses

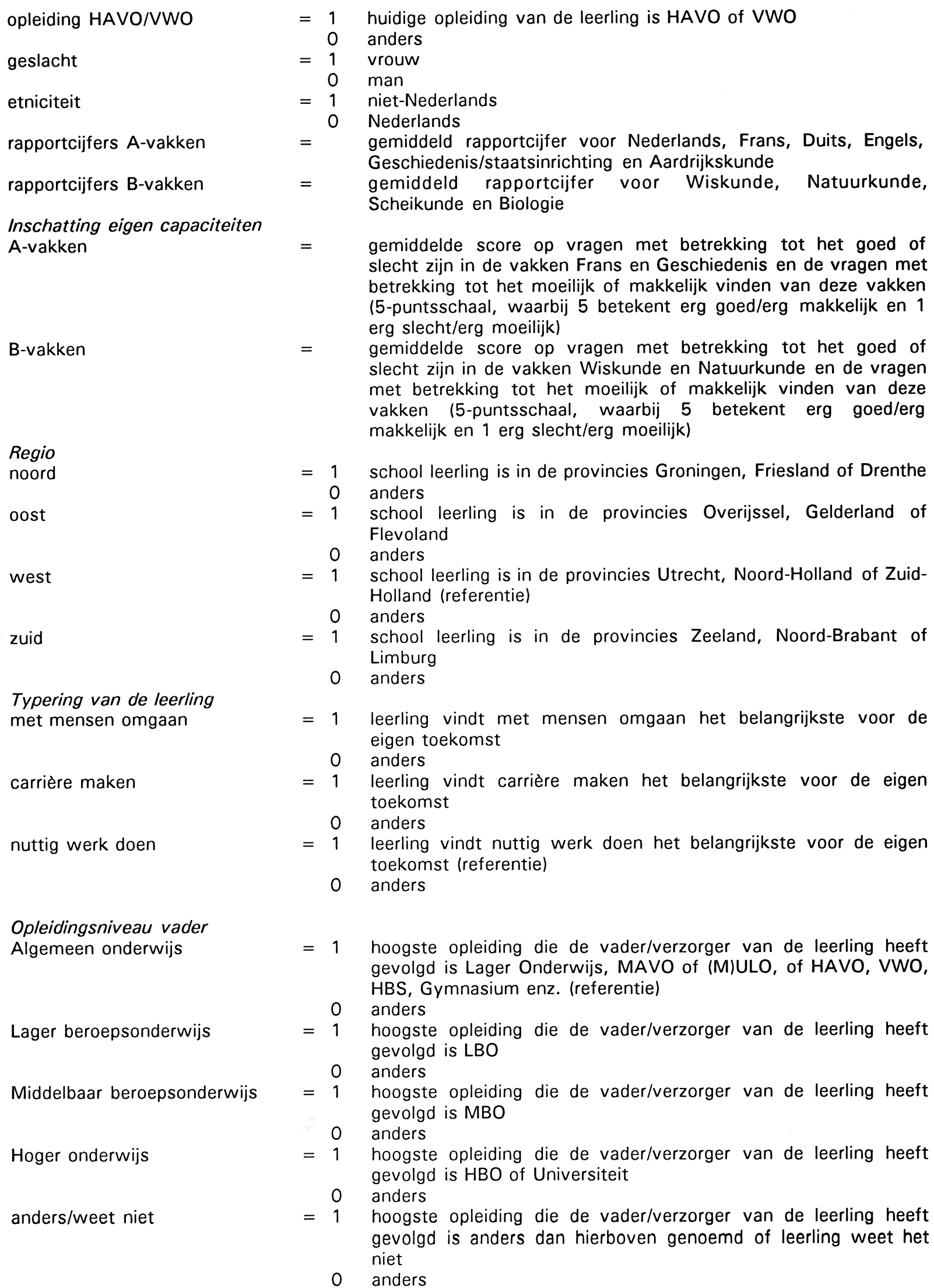


Opleidingsniveau moeder Algemeen onderwijs

Lager beroepsonderwijs

Middelbaar beroepsonderwijs

Hoger onderwijs

anders/weet niet

\section{Beroepsrichting vader} technisch

economisch medisch/dienstverl./verzorgend

overig

nooit beroep gehad/weet niet

Beroepsrichting moeder technisch

economisch

medisch/dienstverl./verzorgend

overig

nooit beroep gehad/weet niet

interesse

consequenties
$=1$ hoogste opleiding die de moeder/verzorgster van de leerling heeft gevolgd is Lager Onderwijs, MAVO of (M)ULO, of HAVO, VWO, HBS, Gymnasium enz. (referentie)

0 anders

$=1$ hoogste opleiding die de moeder/verzorgster van de leerling heeft gevolgd is LBO

0 anders

$=1$ hoogste opleiding die de moeder/verzorgster van de leerling heeft gevolgd is MBO

0 anders

$=1$ hoogste opleiding die de moeder/verzorgster van de leerling heeft gevolgd is HBO of Universiteit

0 anders

$=1$ hoogste opleiding die de moeder/verzorgster van de leerling heeft gevolgd is anders dan hierboven genoemd of leerling weet het niet

0 anders

$=1$ huidige of laatst uitgeoefende beroep van de vader/verzorger van de leerling is in de technische richting

0 anders

$=1$ huidige of laatst uitgeoefende beroep van de vader/verzorger van de leerling is in de economische richting

0 anders

$=1$ huidige of laatst uitgeoefende beroep van de vader/verzorger van de leerling is in de medische, dienstverlenende of verzorgende richting

0 anders

$=1$ huidige of laatst uitgeoefende beroep van de vader/verzorger van de leerling is anders dan hierboven genoemd (referentie)

0 anders

$=1$ vader/verzorger van de leerling heeft nooit een beroep gehad of leerling weet het niet

0 anders

$=1$ huidige of laatst uitgeoefende beroep van de moeder/verzorgster van de leerling is in de technische richting

0 anders

$=1$ huidige of laatst uitgeoefende beroep van de moeder/verzorgster van de leerling is in de economische richting

0 anders

$=1$ huidige of laatst uitgeoefende beroep van de moeder/verzorgster van de leerling is in de medische, dienstverlenende of verzorgende richting

0 anders

$=1$ huidige of laatst uitgeoefende beroep van de moeder/verzorgster van de leerling is anders dan hierboven genoemd (referentie)

0 anders

$=1$ moeder/verzorgster van de leerling heeft nooit een beroep gehad of leerling weet het niet

0 anders

$=\quad$ gemiddelde score op items met betrekking tot de interesseschaal (5-puntsschaal, waarbij 5 betekent erg veel interesse en 1 erg weinig interesse)

$=\quad$ gemiddelde score op items met betrekking tot de consequentiesschaal (5-puntsschaal, waarbij 5 betekent erg positief over de gevolgen van technologische ontwikkeling en 1 erg negatief over de gevolgen van technologische ontwikkeling) 
imago: moeilijkheidsgraad

imago: arbeidsmarktpositie

imago: kwalitatieve aspecten van het werk $=\quad$ beeld dat de leerling heeft van de moeilijkheidsgraad van de technische (vervolg-)opleiding (schaal van 0 tot 100 , waarbij 100 betekent dat het technisch onderwijs verhoudingsgewijs het makkelijkste is en 0 dat het technisch onderwijs verhoudingsgewijs het moeilijkste)

$=\quad$ gemiddelde beeld dat de leerling heeft van de arbeidsmarktpositie van technisch opgeleiden, bepaald als het ongewogen gemiddelde van dit beeld ten aanzien van de verwachte kans op werk en de verwachte kans op een hoog inkomen (schaal van 0 tot 100, waarbij 100 betekent een verhoudingsgewijs erg positief beeld van de arbeidsmarktpositie en 0 een erg negatief beeld hiervan)

$=$ gemiddelde beeld dat de leerling heeft van de kwalitatieve aspecten van het werk van technisch opgeleiden, bepaald als het ongewogen gemiddelde van dit beeld ten aanzien van de verwachte kans op lichamelijk zwaar werk, stress, vuil werk, saai werk en werk met veel zelfstandigheid (schaal van 0 tot 100, waarbij 100 betekent een verhoudingsgewijs erg positief beeld van de kwalitatieve aspecten van het werk en 0 een erg negatief beeld hiervan) 


\section{BIJLAGE D}

ENKELE AANVULLENDE TABELLEN 


\section{MOEILIJKHEIDSGRAAD VAN DE OPLEIDING}

Tabel 6.1a. Verwachte moeilijkheidsgraad van vervolgopleidingen voor VBO-Techniek-leerlingen

\begin{tabular}{|c|c|c|c|c|c|}
\hline Vervolgopleiding & $\begin{array}{c}1 \\
\text { moeilijkste }\end{array}$ & 2 & 3 & $\begin{array}{c}4 \\
\text { makkelijkste }\end{array}$ & $\begin{array}{l}\text { gemiddelde } \\
\text { positie }\end{array}$ \\
\hline & $\%$ & $\%$ & $\%$ & $\%$ & \\
\hline middelbaar agrarisch onderwijs & 6 & 13 & 33 & 48 & 3,2 \\
\hline middelbaar technisch onderwijs & 27 & 35 & 24 & 15 & 2,3 \\
\hline middelbaar economisch-administratief onderwijs & 49 & 28 & 15 & 8 & 1,8 \\
\hline middelbaar dienstverlenend/gezondheidszorg onderwijs & is 19 & 24 & 28 & 29 & 2,7 \\
\hline
\end{tabular}

Tabel 6.1b. Verwachte moeilijkheidsgraad van vervolgopleidingen voor VBO-Overig-leerlingen

\begin{tabular}{|c|c|c|c|c|c|}
\hline Vervolgopleiding & $\begin{array}{c}1 \\
\text { moeilijkste }\end{array}$ & 2 & 3 & $\begin{array}{c}4 \\
\text { makkelijkste }\end{array}$ & $\begin{array}{l}\text { gemiddelde } \\
\text { positie }\end{array}$ \\
\hline & $\%$ & $\%$ & $\%$ & $\%$ & \\
\hline middelbaar agrarisch onderwijs & 6 & 16 & 29 & 49 & 3,2 \\
\hline middelbaar technisch onderwijs & 19 & 31 & 33 & 17 & 2,5 \\
\hline middelbaar economisch-administratief onderwijs & 62 & 20 & 10 & 9 & 1,7 \\
\hline middelbaar dienstverlenend/gezondheidszorg onderwijs & s 13 & 32 & 28 & 26 & 2,8 \\
\hline
\end{tabular}

Tabel 6.1c. Verwachte moeilijkheidsgraad van vervolgopleidingen voor MAVO-leerlingen

\begin{tabular}{|c|c|c|c|c|c|}
\hline Vervolgopleiding & $\begin{array}{c}1 \\
\text { moeilijkste }\end{array}$ & 2 & 3 & $\stackrel{4}{\text { makkelijkste }}$ & $\begin{array}{l}\text { gemiddelde } \\
\text { positie }\end{array}$ \\
\hline & $\%$ & $\%$ & $\%$ & $\%$ & \\
\hline middelbaar agrarisch onderwijs & 6 & 14 & 30 & 51 & 3,3 \\
\hline middelbaar technisch onderwijs & 24 & 33 & 29 & 14 & 2,3 \\
\hline middelbaar economisch-administratief onderwijs & 54 & 26 & 12 & 8 & 1,7 \\
\hline middelbaar dienstverlenend/gezondheidszorg onderwijs & s 16 & 27 & 29 & 28 & 2,7 \\
\hline
\end{tabular}


$-137-$

Tabel 6.1d. Verwachte moeilijkheidsgraad van vervolgopleidingen voor HAVO-leerlingen

\begin{tabular}{|c|c|c|c|c|c|c|c|}
\hline Vervolgopleiding & $\begin{array}{c}1 \\
\text { moeilijkste }\end{array}$ & 2 & 3 & 4 & 5 & $\begin{array}{c}6 \\
\text { makkelijkste }\end{array}$ & $\begin{array}{l}\text { gemiddelde } \\
\text { positie }\end{array}$ \\
\hline & $\%$ & $\%$ & $\%$ & $\%$ & $\%$ & $\%$ & \\
\hline hoger pedagogisch onderwijs & 1 & 7 & 19 & 28 & 21 & 25 & 4,4 \\
\hline hoger agrarisch onderwijs & 2 & 8 & 15 & 20 & 24 & 32 & 4,5 \\
\hline hoger technisch onderwijs & $3 \overline{6}$ & 30 & 13 & 7 & 9 & 4 & 2,4 \\
\hline hoger economisch onderwijs & 42 & 31 & 14 & 6 & 5 & 3 & 2,1 \\
\hline hoger sociaal-cultureel onderwijs & 4 & 10 & 9 & 21 & 26 & 31 & 4,5 \\
\hline hoger gezondheidszorgonderwijs & 15 & 14 & 30 & 18 & 15 & 6 & 3,2 \\
\hline
\end{tabular}

Tabel 6.1e. Verwachte moeilijkheidsgraad van vervolgopleidingen voor VWO-leerlingen

\begin{tabular}{|c|c|c|c|c|c|c|c|c|}
\hline \multirow[t]{2}{*}{ Vervolgopleiding } & \multicolumn{2}{|c|}{$\begin{array}{c}1 \\
\text { moeilijkste }\end{array}$} & 3 & 4 & 5 & 6 & \multicolumn{2}{|c|}{ makkelijkste positie } \\
\hline & $\%$ & $\%$ & $\%$ & $\%$ & $\%$ & $\%$ & $\%$ & \\
\hline letteren & 11 & 10 & 11 & 16 & 18 & 13 & 21 & 4,4 \\
\hline agrarische wetenschappen & 1 & 7 & 7 & 12 & 16 & 22 & 36 & 5,5 \\
\hline technische wetenschappen & 33 & 19 & 15 & 11 & 9 & 10 & 4 & 2,9 \\
\hline economie & 4 & 12 & 22 & 17 & 21 & 17 & 6 & 4,1 \\
\hline rechten & 19 & 24 & 10 & 12 & 11 & 9 & 15 & 3,6 \\
\hline sociale wetenschappen & 1 & 7 & 13 & 22 & 16 & 25 & 16 & 4,8 \\
\hline medische wetenschappen & 30 & 22 & 23 & 9 & 9 & 5 & 2 & 2,7 \\
\hline
\end{tabular}




\section{ARBEIDSMARKTPOSITIE: WERK EN INKOMEN}

Tabel 7.1a. Verwachte kans op werk van vervolgopleidingen voor VBO-Techniek-leerlingen

\begin{tabular}{|c|c|c|c|c|c|}
\hline Vervolgopleiding & $\begin{array}{c}1 \\
\text { grootste }\end{array}$ & 2 & 3 & $\begin{array}{c}4 \\
\text { kleinste }\end{array}$ & $\begin{array}{l}\text { gemiddelde } \\
\text { positie }\end{array}$ \\
\hline & $\%$ & $\%$ & $\%$ & $\%$ & \\
\hline middelbaar agrarisch onderwijs & 3 & 18 & 29 & 50 & 3,3 \\
\hline middelbaar technisch onderwijs & 69 & 13 & 11 & 6 & 1,5 \\
\hline middelbaar economisch-administratief onderwijs & 11 & 43 & 29 & 17 & 2,5 \\
\hline middelbaar dienstverlenend/gezondheidszorg onderwijs & 17 & 26 & 30 & 26 & 2,7 \\
\hline
\end{tabular}

Tabel 7.1b. Verwachte kans op werk van vervolgopleidingen voor VBO-Overig-leerlingen

\begin{tabular}{|c|c|c|c|c|c|}
\hline Vervolgopleiding & $\begin{array}{c}1 \\
\text { grootste }\end{array}$ & 2 & 3 & $\begin{array}{c}4 \\
\text { kleinste }\end{array}$ & $\begin{array}{l}\text { gemiddelde } \\
\text { positie }\end{array}$ \\
\hline & $\%$ & $\%$ & $\%$ & $\%$ & \\
\hline middelbaar agrarisch onderwijs & 8 & 18 & 25 & 49 & 3,2 \\
\hline middelbaar technisch onderwijs & 15 & 27 & 35 & 22 & 2,7 \\
\hline middelbaar economisch-administratief onderwijs & 37 & 26 & 22 & 15 & 2,2 \\
\hline middelbaar dienstverlenend/gezondheidszorg onderwijs & s 41 & 28 & 16 & 15 & 2,1 \\
\hline
\end{tabular}

Tabel 7.1c. Verwachte kans op werk van vervolgopleidingen voor MAVO-leerlingen

\begin{tabular}{|c|c|c|c|c|c|}
\hline Vervolgopleiding & $\begin{array}{c}1 \\
\text { grootste }\end{array}$ & 2 & 3 & $\begin{array}{c}4 \\
\text { kleinste }\end{array}$ & $\begin{array}{l}\text { gemiddelde } \\
\text { positie }\end{array}$ \\
\hline & $\%$ & $\%$ & $\%$ & $\%$ & \\
\hline middelbaar agrarisch onderwijs & 5 & 10 & 23 & 62 & 3,4 \\
\hline middelbaar technisch onderwijs & 26 & 27 & 34 & 13 & 2,3 \\
\hline middelbaar economisch-administratief onderwijs & 41 & 35 & 14 & 10 & 1,9 \\
\hline middelbaar dienstverlenend/gezondheidszorg onderwijs & 28 & 29 & 29 & 15 & 2,3 \\
\hline
\end{tabular}


Tabel 7.1d. Verwachte kans op werk van vervolgopleidingen voor HAVO-leerlingen

\begin{tabular}{|c|c|c|c|c|c|c|c|}
\hline Vervolgopleiding & $\begin{array}{c}1 \\
\text { grootste }\end{array}$ & 2 & 3 & 4 & 5 & $\begin{array}{c}6 \\
\text { kleinste }\end{array}$ & $\begin{array}{l}\text { gemiddelde } \\
\text { positie }\end{array}$ \\
\hline & $\%$ & $\%$ & $\%$ & $\%$ & $\%$ & $\%$ & \\
\hline hoger pedagogisch onderwijs & 15 & 12 & 15 & 19 & 16 & 24 & 3,8 \\
\hline hoger agrarisch onderwijs & 2 & 9 & 13 & 18 & 23 & 35 & 4,6 \\
\hline hoger technisch onderwijs & $3 \overline{6}$ & 21 & 14 & 12 & 12 & 6 & 2,6 \\
\hline hoger economisch onderwijs & 30 & 33 & 13 & 12 & 8 & 5 & 2,5 \\
\hline hoger sociaal-cultureel onderwijs & 6 & 11 & 20 & 18 & 28 & 19 & 4,1 \\
\hline hoger gezondheidszorgonderwijs & 13 & 15 & 24 & 20 & 14 & 13 & 3,5 \\
\hline
\end{tabular}

Tabel 7.1e. Verwachte kans op werk van vervolgopleidingen voor VWO-leerlingen

\begin{tabular}{|c|c|c|c|c|c|c|c|c|}
\hline Vervolgopleiding & $\begin{array}{c}1 \\
\text { grootste }\end{array}$ & 2 & 3 & 4 & 5 & 6 & $\begin{array}{c}7 \\
\text { kleinste }\end{array}$ & $\begin{array}{l}\text { gemiddelde } \\
\text { positie }\end{array}$ \\
\hline & $\%$ & $\%$ & $\%$ & $\%$ & $\%$ & $\%$ & $\%$ & \\
\hline letteren & 2 & 8 & 7 & 15 & 18 & 20 & 29 & 5,1 \\
\hline agrarische wetenschappen & 2 & 7 & 12 & 11 & 16 & 19 & 33 & 5,2 \\
\hline technische wetenschappen & 39 & 19 & 11 & 11 & 10 & 7 & 4 & 2,7 \\
\hline economie & 14 & 20 & 21 & 14 & 13 & 12 & 6 & 3,5 \\
\hline rechten & 8 & 14 & 12 & 22 & 15 & 13 & 15 & 4,2 \\
\hline sociale wetenschappen & 9 & 16 & 14 & 16 & 18 & 20 & 8 & 4,1 \\
\hline medische wetenschappen & 26 & 16 & 22 & 12 & 8 & 9 & 6 & 3,1 \\
\hline
\end{tabular}

Tabel 7.2a. Verwachte inkomensverhoudingen van vervolgopleidingen voor VBO-Techniek-leerlingen

\begin{tabular}{|c|c|c|c|c|c|}
\hline Vervolgopleiding & $\begin{array}{c}1 \\
\text { hoogste }\end{array}$ & 2 & 3 & $\begin{array}{c}4 \\
\text { laagste }\end{array}$ & $\begin{array}{l}\text { gemiddelde } \\
\text { positie }\end{array}$ \\
\hline & $\%$ & $\%$ & $\%$ & $\%$ & \\
\hline middelbaar agrarisch onderwijs & 5 & 14 & 29 & 52 & 3,3 \\
\hline middelbaar technisch onderwijs & 45 & 32 & 17 & 6 & 1,9 \\
\hline middelbaar economisch-administratief onderwijs & 39 & 34 & 18 & 9 & 2,0 \\
\hline middelbaar dienstverlenend/gezondheidszorg onderwijs & 12 & 20 & 36 & 33 & 2,9 \\
\hline
\end{tabular}


Tabel 7.2b. Gepercipieerde inkomensverhoudingen van vervolgopleidingen voor VBO-Overig-leerlingen

\begin{tabular}{|c|c|c|c|c|c|}
\hline Vervolgopleiding & $\begin{array}{c}1 \\
\text { hoogste }\end{array}$ & 2 & 3 & $\begin{array}{c}4 \\
\text { laagste }\end{array}$ & $\begin{array}{l}\text { gemiddelde } \\
\text { positie }\end{array}$ \\
\hline & $\%$ & $\%$ & $\%$ & $\%$ & \\
\hline middelbaar agrarisch onderwijs & 6 & 18 & 27 & 49 & 3,2 \\
\hline middelbaar technisch onderwijs & 15 & 32 & 36 & 17 & 2,5 \\
\hline middelbaar economisch-administratief onderwijs & 61 & 20 & 11 & 9 & 1,7 \\
\hline middelbaar dienstverlenend/gezondheidszorg onderwijs & 19 & 29 & 26 & 26 & 2,6 \\
\hline
\end{tabular}

Tabel 7.2c. Verwachte inkomensverhoudingen van vervolgopleidingen voor MAVO-leerlingen

\begin{tabular}{|c|c|c|c|c|c|}
\hline Vervolgopleiding & $\begin{array}{c}1 \\
\text { hoogste }\end{array}$ & 2 & 3 & $\begin{array}{c}4 \\
\text { laagste }\end{array}$ & $\begin{array}{l}\text { gemiddelde } \\
\text { positie }\end{array}$ \\
\hline & $\%$ & $\%$ & $\%$ & $\%$ & \\
\hline middelbaar agrarisch onderwijs & 3 & 12 & 28 & 57 & 3,4 \\
\hline middelbaar technisch onderwijs & 20 & 40 & 30 & 11 & 2,3 \\
\hline middelbaar economisch-administratief onderwijs & 68 & 21 & 8 & 3 & 1,5 \\
\hline middelbaar dienstverlenend/gezondheidszorg onderwijs & 9 & 27 & 34 & 29 & 2,8 \\
\hline
\end{tabular}

Tabel 7.2d. Verwachte inkomensverhoudingen van vervolgopleidingen voor HAVO-leerlingen

\begin{tabular}{lrrrrrrr}
\hline Vervolgopleiding & $\begin{array}{c}1 \\
\text { hoogste }\end{array}$ & 2 & 3 & 4 & 5 & $\begin{array}{c}6 \\
\text { laagste }\end{array}$ & $\begin{array}{c}\text { gemiddelde } \\
\text { positie }\end{array}$ \\
& $\%$ & $\%$ & $\%$ & $\%$ & $\%$ & $\%$ & \\
& & & & & & & \\
& 3 & 3 & 9 & 32 & 26 & 28 & 4,6 \\
hoger pedagogisch onderwijs & 2 & 6 & 15 & 20 & 29 & 27 & 4,5 \\
hoger agrarisch onderwijs & 29 & 30 & 23 & 10 & 7 & 2 & 2,4 \\
hoger technisch onderwijs & 44 & 38 & 11 & 19 & 2 & 3 & 1,9 \\
hoger economisch onderwijs & 1 & 5 & 12 & 21 & 27 & 34 & 4,7 \\
hoger sociaal-cultureel onderwijs & 22 & 19 & 29 & 15 & 8 & 7 & 2,9 \\
hoger gezondheidszorgonderwijs & 22 & & & & &
\end{tabular}


$-141-$

Tabel 7.2e. Verwachte inkomensverhoudingen van vervolgopleidingen voor VWO-leerlingen

\begin{tabular}{lrrrrrrrr}
\hline Vervolgopleiding & $\begin{array}{c}1 \\
\text { hoogste }\end{array}$ & 2 & 3 & 4 & 5 & 6 & $\begin{array}{c}7 \\
\text { laagste }\end{array}$ \\
& $\%$ & $\%$ & $\%$ & $\%$ & $\%$ & $\%$ & $\%$ & \\
& & & & & & & \\
& & & & & & & & \\
positid \\
letteren & 1 & 4 & 6 & 8 & 25 & 30 & 25 & 5,4 \\
agrarische wetenschappen & 0 & 3 & 2 & 7 & 14 & 25 & 48 & 6,0 \\
technische wetenschappen & 11 & 17 & 27 & 24 & 14 & 6 & 2 & 3,4 \\
economie & 10 & 20 & 21 & 28 & 12 & 6 & 2 & 3,4 \\
rechten & 33 & 31 & 17 & 11 & 6 & 1 & 2 & 2,4 \\
sociale wetenschappen & 0 & 4 & 15 & 14 & 24 & 25 & 17 & 5,0 \\
medische wetenschappen & 45 & 23 & 12 & 8 & 4 & 5 & 3 & 2,3 \\
\end{tabular}




\section{KWALITATIEVE ASPECTEN VAN HET WERK}

Tabel 8.1a. Verwachte kans op lichamelijk zwaar werk van vervolgopleidingen voor VBO-Techniekleerlingen

\begin{tabular}{|c|c|c|c|c|c|}
\hline Vervolgopleiding & $\begin{array}{c}1 \\
\text { grootste }\end{array}$ & 2 & 3 & $\begin{array}{c}4 \\
\text { kleinste }\end{array}$ & $\begin{array}{c}\text { gemiddelde } \\
\text { positie }\end{array}$ \\
\hline & $\%$ & $\%$ & $\%$ & $\%$ & \\
\hline middelbaar agrarisch onderwijs & 36 & 32 & 18 & 14 & 2,1 \\
\hline middelbaar technisch onderwijs & 40 & 32 & 20 & 7 & 1,9 \\
\hline middelbaar economisch-administratief onderwijs & 7 & 12 & 19 & 62 & 3,4 \\
\hline middelbaar dienstverlenend/gezondheidszorg onderwijs & 17 & 24 & 42 & 17 & 2,6 \\
\hline
\end{tabular}

Tabel 8.1b. Verwachte kans op lichamelijk zwaar werk van vervolgopleidingen voor VBO-Overigleerlingen

\begin{tabular}{|c|c|c|c|c|c|}
\hline Vervolgopleiding & $\begin{array}{c}1 \\
\text { grootste }\end{array}$ & 2 & 3 & $\begin{array}{c}4 \\
\text { kleinste }\end{array}$ & $\begin{array}{c}\text { gemiddelde } \\
\text { positie }\end{array}$ \\
\hline & $\%$ & $\%$ & $\%$ & $\%$ & \\
\hline middelbaar agrarisch onderwijs & 28 & 34 & 26 & 12 & 2,2 \\
\hline middelbaar technisch onderwijs & 28 & 32 & 34 & 7 & 2,2 \\
\hline middelbaar economisch-administratief onderwijs & 6 & 9 & 12 & 73 & 3,5 \\
\hline middelbaar dienstverlenend/gezondheidszorg onderwijs & s 40 & 24 & 28 & 9 & 2,1 \\
\hline
\end{tabular}

Tabel 8.1c. Verwachte kans op lichamelijk zwaar werk van vervolgopleidingen voor MAVO-leerlingen

\begin{tabular}{|c|c|c|c|c|c|}
\hline Vervolgopleiding & $\begin{array}{c}1 \\
\text { grootste }\end{array}$ & 2 & 3 & $\begin{array}{c}4 \\
\text { kleinste }\end{array}$ & $\begin{array}{l}\text { gemiddelde } \\
\text { positie }\end{array}$ \\
\hline & $\%$ & $\%$ & $\%$ & $\%$ & \\
\hline middelbaar agrarisch onderwijs & 50 & 29 & 16 & 6 & 1,8 \\
\hline middelbaar technisch onderwijs & 23 & 36 & 34 & 8 & 2,3 \\
\hline middelbaar economisch-administratief onderwijs & 3 & 8 & 11 & 79 & 3,7 \\
\hline middelbaar dienstverlenend/gezondheidszorg onderwijs & 25 & 28 & 39 & 7 & 2,3 \\
\hline
\end{tabular}


Tabel 8.1d. Verwachte kans op lichamelijk zwaar werk van vervolgopleidingen voor HAVO-leerlingen

\begin{tabular}{|c|c|c|c|c|c|c|c|}
\hline Vervolgopleiding & $\begin{array}{c}1 \\
\text { grootste }\end{array}$ & 2 & 3 & 4 & 5 & $\begin{array}{c}6 \\
\text { kleinste }\end{array}$ & $\begin{array}{c}\text { gemiddelde } \\
\text { positie }\end{array}$ \\
\hline & $\%$ & $\%$ & $\%$ & $\%$ & $\%$ & $\%$ & \\
\hline hoger pedagogisch onderwijs & 6 & 13 & 16 & 26 & 22 & 18 & 4,0 \\
\hline hoger agrarisch onderwijs & 61 & 18 & 8 & 7 & 3 & 3 & 1,8 \\
\hline hoger technisch onderwijs & 11 & 31 & 16 & 11 & 24 & 7 & 3,2 \\
\hline hoger economisch onderwijs & 3 & 3 & 2 & 10 & 25 & 57 & 5,2 \\
\hline hoger sociaal-cultureel onderwijs & 9 & 15 & 25 & 29 & 15 & 8 & 3,5 \\
\hline hoger gezondheidszorgonderwijs & 11 & 21 & 33 & 18 & 10 & 7 & 3,2 \\
\hline
\end{tabular}

Tabel 8.1e. Verwachte kans op lichamelijk zwaar werk van vervolgopleidingen voor VWO-leerlingen

\begin{tabular}{|c|c|c|c|c|c|c|c|c|}
\hline Vervolgopleiding & $\begin{array}{c}1 \\
\text { grootste }\end{array}$ & 2 & 3 & 4 & 5 & 6 & $\begin{array}{c}7 \\
\text { kleinste }\end{array}$ & $\begin{array}{l}\text { gemiddelde } \\
\text { positie }\end{array}$ \\
\hline & $\%$ & $\%$ & $\%$ & $\%$ & $\%$ & $\%$ & $\%$ & \\
\hline letteren & 2 & 4 & 5 & 9 & 12 & 14 & 54 & 5,8 \\
\hline agrarische wetenschappen & 60 & 20 & 6 & 5 & 3 & 3 & 4 & 1,9 \\
\hline technische wetenschappen & 5 & 19 & 21 & 18 & 18 & 14 & 6 & 3,9 \\
\hline economie & 1 & 2 & 4 & 20 & 32 & 30 & 11 & 5,2 \\
\hline rechten & 2 & 3 & 13 & 12 & 23 & 25 & 21 & 5,1 \\
\hline sociale wetenschappen & 3 & 22 & 26 & 25 & 8 & 12 & 4 & 3,7 \\
\hline medische wetenschappen & 27 & 32 & 25 & 11 & 3 & 2 & 0 & 2,4 \\
\hline
\end{tabular}

Tabel 8.3a. Verwachte kans op een beroep met veel stress van vervolgopleidingen voor VBO-Techniekleerlingen

\begin{tabular}{|c|c|c|c|c|c|}
\hline Vervolgopleiding & $\begin{array}{c}1 \\
\text { grootste }\end{array}$ & 2 & 3 & $\begin{array}{c}4 \\
\text { kleinste }\end{array}$ & $\begin{array}{l}\text { gemiddelde } \\
\text { positie }\end{array}$ \\
\hline & $\%$ & $\%$ & $\%$ & $\%$ & \\
\hline middelbaar agrarisch onderwijs & 8 & 17 & 35 & 40 & 3,1 \\
\hline middelbaar technisch onderwijs & 12 & 12 & 38 & 38 & 3,0 \\
\hline middelbaar economisch-administratief onderwijs & 49 & 31 & 12 & 8 & 1,8 \\
\hline middelbaar dienstverlenend/gezondheidszorg onderwijs & 532 & 40 & 14 & 14 & 2,1 \\
\hline
\end{tabular}


Tabel 8.3b. Verwachte kans op een beroep met veel stress van vervolgopleidingen voor VBO-Overigleerlingen

\begin{tabular}{lccccc}
\hline Vervolgopleiding & $\begin{array}{c}1 \\
\text { grootste }\end{array}$ & 2 & 3 & $\begin{array}{c}4 \\
\text { kleinste }\end{array}$ & $\begin{array}{c}\text { gemiddelde } \\
\text { positie }\end{array}$ \\
\hline & $\%$ & $\%$ & $\%$ & $\%$ & \\
middelbaar agrarisch onderwijs & 9 & 13 & 27 & 51 & 3,2 \\
middelbaar technisch onderwijs & 11 & 19 & 45 & 25 & 2,8 \\
middelbaar economisch-administratief onderwijs & 47 & 30 & 11 & 12 & 1,9 \\
middelbaar dienstverlenend/gezondheidszorg onderwijs & 33 & 38 & 17 & 13 & 2,1 \\
\hline
\end{tabular}

Tabel 8.3c. Verwachte kans op een beroep met veel stress van vervolgopleidingen voor MAVO-leerlingen

\begin{tabular}{lccccc}
\hline Vervolgopleiding & $\begin{array}{c}1 \\
\text { grootste }\end{array}$ & 2 & 3 & $\begin{array}{c}4 \\
\text { kleinste }\end{array}$ & $\begin{array}{c}\text { gemiddelde } \\
\text { positie }\end{array}$ \\
\hline & $\%$ & $\%$ & $\%$ & $\%$ & \\
middelbaar agrarisch onderwijs & & & & & \\
middelbaar technisch onderwijs & 6 & 12 & 24 & 58 & 3,3 \\
middelbaar economisch-administratief onderwijs & 6 & 20 & 48 & 27 & 3,0 \\
middelbaar dienstverlenend/gezondheidszorg onderwijs & 33 & 27 & 10 & 7 & 1,7 \\
\hline
\end{tabular}

Tabel 8.3d. Verwachte kans op een beroep met veel stress van vervolgopleidingen voor HAVO-leerlingen

\begin{tabular}{|c|c|c|c|c|c|c|c|}
\hline Vervolgopleiding & $\begin{array}{l}1 \\
\text { grootste }\end{array}$ & 2 & 3 & 4 & 5 & $\begin{array}{c}6 \\
\text { kleinste }\end{array}$ & $\begin{array}{l}\text { gemiddelde } \\
\text { positie }\end{array}$ \\
\hline & $\%$ & $\%$ & $\%$ & $\%$ & $\%$ & $\%$ & \\
\hline hoger pedagogisch onderwijs & 52 & 24 & 16 & 2 & 3 & 3 & 1,9 \\
\hline hoger agrarisch onderwijs & 3 & 4 & 7 & 21 & 21 & 43 & 4,8 \\
\hline hoger technisch onderwijs & 2 & 6 & 10 & 17 & 44 & 21 & 4,6 \\
\hline hoger economisch onderwijs & 20 & 25 & 15 & 20 & 9 & 12 & 3,1 \\
\hline hoger sociaal-cultureel onderwijs & 20 & 32 & 22 & 12 & 9 & 6 & 2,8 \\
\hline hoger gezondheidszorgonderwijs & 4 & 9 & 30 & 28 & 15 & 16 & 3,9 \\
\hline
\end{tabular}


$-145-$

Tabel 8.3e. Verwachte kans op een beroep met veel stress van vervolgopleidingen voor VWO-leerlingen

\begin{tabular}{|c|c|c|c|c|c|c|c|c|}
\hline Vervolgopleiding & $\begin{array}{c}1 \\
\text { grootste }\end{array}$ & 2 & 3 & 4 & 5 & 6 & $\begin{array}{c}7 \\
\text { kleinste }\end{array}$ & $\begin{array}{c}\text { gemiddelde } \\
\text { positie }\end{array}$ \\
\hline & $\%$ & $\%$ & $\%$ & $\%$ & $\%$ & $\%$ & $\%$ & \\
\hline letteren & 4 & 6 & 7 & 14 & 16 & 20 & 35 & 5,3 \\
\hline agrarische wetenschappen & 3 & 3 & 5 & 7 & 14 & 28 & 41 & 5,8 \\
\hline technische wetenschappen & 3 & 5 & 11 & 15 & 27 & 26 & 13 & 4,9 \\
\hline economie & 18 & 11 & 13 & 21 & 22 & 12 & 4 & 3,7 \\
\hline rechten & 23 & 30 & 23 & 13 & 6 & 3 & 3 & 2,7 \\
\hline sociale wetenschappen & 24 & 19 & 21 & 16 & 10 & 7 & 4 & 3,1 \\
\hline medische wetenschappen & 26 & 27 & 22 & 15 & 5 & 4 & 1 & 2,6 \\
\hline
\end{tabular}

Tabel 8.4a. Verwachte kans op een beroep met vaak vuil werk van vervolgopleidingen voor VBOTechniek-leerlingen

\begin{tabular}{lrrrrc}
\hline Vervolgopleiding & $\begin{array}{c}1 \\
\text { grootste }\end{array}$ & 2 & 3 & $\begin{array}{c}4 \\
\text { kleinste }\end{array}$ & $\begin{array}{c}\text { gemiddelde } \\
\text { positie }\end{array}$ \\
\hline & $\%$ & $\%$ & $\%$ & $\%$ & \\
& & & & & \\
middelbaar agrarisch onderwijs & 58 & 26 & 10 & 7 & 1,7 \\
middelbaar technisch onderwijs & 27 & 39 & 27 & 7 & 2,2 \\
middelbaar economisch-administratief onderwijs & 3 & 9 & 16 & 72 & 3,6 \\
middelbaar dienstverlenend/gezondheidszorg onderwijs & 13 & 26 & 46 & 14 & 2,6 \\
\hline
\end{tabular}

Tabel 8.4b. Verwachte kans op een beroep met vaak vuil werk van vervolgopleidingen voor VBO-Overigleerlingen

\begin{tabular}{lrrrrr}
\hline Vervolgopleiding & $\begin{array}{c}1 \\
\text { grootste }\end{array}$ & 2 & 3 & $\begin{array}{c}4 \\
\text { kleinste }\end{array}$ & $\begin{array}{c}\text { gemiddelde } \\
\text { positie }\end{array}$ \\
\hline & $\%$ & $\%$ & $\%$ & $\%$ & \\
& & & & & \\
middelbaar agrarisch onderwijs & 56 & 28 & 11 & 5 & 1,6 \\
$\begin{array}{l}\text { middelbaar technisch onderwijs } \\
\text { middelbaar economisch-administratief onderwijs }\end{array}$ & 24 & 47 & 26 & 3 & 2,1 \\
middelbaar dienstverlenend/gezondheidszorg onderwijs & 18 & 20 & 52 & 11 & 2,6 \\
\hline
\end{tabular}


Tabel 8.4c. Verwachte kans op een beroep met vaak vuil werk van vervolgopleidingen voor MAVOleerlingen

\begin{tabular}{|c|c|c|c|c|c|}
\hline Vervolgopleiding & $\begin{array}{c}1 \\
\text { grootste }\end{array}$ & 2 & 3 & $\begin{array}{c}4 \\
\text { kleinste }\end{array}$ & $\begin{array}{l}\text { gemiddelde } \\
\text { positie }\end{array}$ \\
\hline & $\%$ & $\%$ & $\%$ & $\%$ & \\
\hline middelbaar agrarisch onderwijs & 64 & 25 & 8 & 4 & 1,5 \\
\hline middelbaar technisch onderwijs & 17 & 40 & 36 & 7 & 2,3 \\
\hline middelbaar economisch-administratief onderwijs & 2 & 3 & 11 & 84 & 3,8 \\
\hline middelbaar dienstverlenend/gezondheidszorg onderwijs & 17 & 33 & 45 & 6 & 2,4 \\
\hline
\end{tabular}

Tabel 8.4d. Verwachte kans op een beroep met vaak vuil werk van vervolgopleidingen voor HAVOleerlingen

\begin{tabular}{|c|c|c|c|c|c|c|c|}
\hline Vervolgopleiding & $\begin{array}{c}1 \\
\text { grootste }\end{array}$ & 2 & 3 & 4 & 5 & $\begin{array}{c}6 \\
\text { kleinste }\end{array}$ & $\begin{array}{c}\text { gemiddelde } \\
\text { positie }\end{array}$ \\
\hline & $\%$ & $\%$ & $\%$ & $\%$ & $\%$ & $\%$ & \\
\hline hoger pedagogisch onderwijs & 2 & 6 & 10 & 22 & 38 & 22 & 4,5 \\
\hline hoger agrarisch onderwijs & 69 & 19 & 7 & 1 & 1 & 3 & 1,6 \\
\hline hoger technisch onderwijs & 11 & 38 & 14 & 19 & 14 & 4 & 3,0 \\
\hline hoger economisch onderwijs & 2 & 2 & 1 & 9 & 24 & 63 & 5,4 \\
\hline hoger sociaal-cultureel onderwijs & $\overline{9}$ & 16 & 32 & 26 & 13 & 4 & 3,3 \\
\hline hoger gezondheidszorgonderwijs & 8 & 19 & 35 & 24 & 10 & 4 & 3,2 \\
\hline
\end{tabular}

Tabel 8.4e. Verwachte kans op een beroep met vaak vuil werk van vervolgopleidingen voor VWOleerlingen

\begin{tabular}{|c|c|c|c|c|c|c|c|c|}
\hline Vervolgopleiding & $\begin{array}{c}1 \\
\text { grootste }\end{array}$ & 2 & 3 & 4 & 5 & 6 & $\begin{array}{c}7 \\
\text { kleinste }\end{array}$ & $\begin{array}{l}\text { gemiddelde } \\
\text { positie }\end{array}$ \\
\hline & $\%$ & $\%$ & $\%$ & $\%$ & $\%$ & $\%$ & $\%$ & \\
\hline letteren & 1 & 1 & 6 & 8 & 21 & 16 & 48 & 5,9 \\
\hline agrarische wetenschappen & 68 & 21 & 4 & 5 & 2 & 1 & 0 & 1,6 \\
\hline technische wetenschappen & 4 & 23 & 28 & 24 & 8 & 8 & 4 & 3,5 \\
\hline economie & 1 & 2 & 16 & 33 & 33 & 15 & 2 & 5,4 \\
\hline rechten & 0 & 4 & 3 & 10 & 24 & 31 & 28 & 5,6 \\
\hline sociale wetenschappen & 6 & 14 & 26 & 33 & 9 & 9 & 3 & 3,6 \\
\hline medische wetenschappen & 21 & 37 & 30 & 6 & 3 & 2 & 2 & 2,4 \\
\hline
\end{tabular}


Tabel 8.6a. Verwachte kans op een beroep met vaak saai werk van vervolgopleidingen voor VBOTechniek-leerlingen

\begin{tabular}{lccccc}
\hline Vervolgopleiding & $\begin{array}{c}1 \\
\text { grootste }\end{array}$ & 2 & 3 & $\begin{array}{c}4 \\
\text { kleinste }\end{array}$ & $\begin{array}{c}\text { gemiddelde } \\
\text { positie }\end{array}$ \\
\hline & $\%$ & $\%$ & $\%$ & $\%$ & \\
middelbaar agrarisch onderwijs & 16 & 28 & 40 & 17 & 2,6 \\
middelbaar technisch onderwijs & 7 & 13 & 22 & 59 & 3,3 \\
middelbaar economisch-administratief onderwijs & 64 & 17 & 14 & 5 & 1,6 \\
middelbaar dienstverlenend/gezondheidszorg onderwijs & 14 & 42 & 25 & 19 & 2,5 \\
\hline
\end{tabular}

Tabel 8.6b. Verwachte kans op een beroep met vaak saai werk van vervolgopleidingen voor VBO-Overigleerlingen

\begin{tabular}{|c|c|c|c|c|c|}
\hline Vervolgopleiding & $\begin{array}{c}1 \\
\text { grootste }\end{array}$ & 2 & 3 & $\begin{array}{c}4 \\
\text { kleinste }\end{array}$ & $\begin{array}{l}\text { gemiddelde } \\
\text { positie }\end{array}$ \\
\hline & $\%$ & $\%$ & $\%$ & $\%$ & \\
\hline middelbaar agrarisch onderwijs & 15 & 28 & 30 & 27 & 2,7 \\
\hline middelbaar technisch onderwijs & 13 & 41 & 34 & 12 & 2,4 \\
\hline middelbaar economisch-administratief onderwijs & 61 & 12 & 13 & 14 & 1,8 \\
\hline middelbaar dienstverlenend/gezondheidszorg onderwijs & 10 & 19 & 22 & 49 & 3,1 \\
\hline
\end{tabular}

Tabel 8.6c. Verwachte kans op een beroep met vaak saai werk van vervolgopleidingen voor MAVOleerlingen

\begin{tabular}{|c|c|c|c|c|c|}
\hline Vervolgopleiding & $\begin{array}{c}1 \\
\text { grootste }\end{array}$ & 2 & 3 & $\begin{array}{c}4 \\
\text { kleinste }\end{array}$ & $\begin{array}{l}\text { gemiddelde } \\
\text { positie }\end{array}$ \\
\hline & $\%$ & $\%$ & $\%$ & $\%$ & \\
\hline middelbaar agrarisch onderwijs & 15 & 27 & 34 & 24 & 2,7 \\
\hline middelbaar technisch onderwijs & 9 & 33 & 33 & 25 & 2,8 \\
\hline middelbaar economisch-administratief onderwijs & 66 & 12 & 10 & 12 & 1,7 \\
\hline middelbaar dienstverlenend/gezondheidszorg onderwijs & s 11 & 28 & 23 & 39 & 2,9 \\
\hline
\end{tabular}


Tabel 8.6d. Verwachte kans op een beroep met vaak saai werk van vervolgopleidingen voor HAVOleerlingen

\begin{tabular}{|c|c|c|c|c|c|c|c|}
\hline Vervolgopleiding & $\begin{array}{c}1 \\
\text { grootste }\end{array}$ & 2 & 3 & 4 & 5 & $\begin{array}{c}6 \\
\text { kleinste }\end{array}$ & $\begin{array}{c}\text { gemiddelde } \\
\text { positie }\end{array}$ \\
\hline & $\%$ & $\%$ & $\%$ & $\%$ & $\%$ & $\%$ & \\
\hline hoger pedagogisch onderwijs & 16 & 21 & 18 & 13 & 14 & 18 & 3,4 \\
\hline hoger agrarisch onderwijs & 8 & 15 & 17 & 20 & 23 & 18 & 3,9 \\
\hline hoger technisch onderwijs & 10 & 23 & 17 & 16 & 20 & 16 & 3,6 \\
\hline hoger economisch onderwijs & 50 & 15 & 10 & 10 & 8 & 8 & 2,3 \\
\hline hoger sociaal-cultureel onderwijs & 12 & 17 & 22 & 16 & 13 & 20 & 3,6 \\
\hline hoger gezondheidszorgonderwijs & 6 & 10 & 17 & 25 & 22 & 21 & 4,1 \\
\hline
\end{tabular}

Tabel 8.6e. Verwachte kans op een beroep met vaak saai werk van vervolgopleidingen voor VWOleerlingen

\begin{tabular}{|c|c|c|c|c|c|c|c|c|}
\hline Vervolgopleiding & $\begin{array}{c}1 \\
\text { grootste }\end{array}$ & 2 & 3 & 4 & 5 & 6 & $\begin{array}{c}7 \\
\text { kleinste }\end{array}$ & $\begin{array}{l}\text { gemiddelde } \\
\text { positie }\end{array}$ \\
\hline & $\%$ & $\%$ & $\%$ & $\%$ & $\%$ & $\%$ & $\%$ & \\
\hline letteren & 42 & 19 & 15 & 12 & 4 & 3 & 6 & 2,5 \\
\hline agrarische wetenschappen & 3 & 9 & 13 & 18 & 22 & 16 & 19 & 4,7 \\
\hline technische wetenschappen & 11 & 13 & 14 & 13 & 18 & 19 & 12 & 4,2 \\
\hline economie & 22 & 23 & 18 & 17 & 10 & 6 & 6 & 3,1 \\
\hline rechten & 17 & 21 & 20 & 12 & 13 & 12 & 6 & 3,4 \\
\hline sociale wetenschappen & 4 & 13 & 15 & 16 & 17 & 21 & 14 & 4,5 \\
\hline medische wetenschappen & 1 & 3 & 6 & 13 & 17 & 24 & 36 & 5,6 \\
\hline
\end{tabular}

Tabel 8.8a. Verwachte kans op een beroep met veel zelfstandigheid van vervolgopleidingen voor VBOTechniek-leerlingen

\begin{tabular}{|c|c|c|c|c|c|}
\hline Vervolgopleiding & $\begin{array}{c}1 \\
\text { grootste }\end{array}$ & 2 & 3 & $\begin{array}{c}4 \\
\text { kleinste }\end{array}$ & $\begin{array}{c}\text { gemiddelde } \\
\text { positie }\end{array}$ \\
\hline & $\%$ & $\%$ & $\%$ & $\%$ & \\
\hline middelbaar agrarisch onderwijs & 25 & 34 & 17 & 24 & 2,4 \\
\hline middelbaar technisch onderwijs & 44 & 25 & 20 & 11 & 2,0 \\
\hline middelbaar economisch-administratief onderwijs & 20 & 21 & 30 & 29 & 2,7 \\
\hline middelbaar dienstverlenend/gezondheidszorg onderwijs & s 12 & 20 & 33 & 35 & 2,9 \\
\hline
\end{tabular}


Tabel 8.8b. Verwachte kans op een beroep met veel zelfstandigheid van vervolgopleidingen voor VBOOverig-leerlingen

\begin{tabular}{|c|c|c|c|c|c|}
\hline Vervolgopleiding & $\begin{array}{c}1 \\
\text { grootste }\end{array}$ & 2 & 3 & $\begin{array}{c}4 \\
\text { kleinste }\end{array}$ & $\begin{array}{l}\text { gemiddelde } \\
\text { positie }\end{array}$ \\
\hline & $\%$ & $\%$ & $\%$ & $\%$ & \\
\hline middelbaar agrarisch onderwijs & 27 & 28 & 23 & 22 & 2,4 \\
\hline middelbaar technisch onderwijs & 11 & 30 & 37 & 22 & 2,7 \\
\hline middelbaar economisch-administratief onderwijs & 32 & 18 & 18 & 32 & 2,5 \\
\hline middelbaar dienstverlenend/gezondheidszorg onderwijs & 30 & 24 & 21 & 26 & 2,4 \\
\hline
\end{tabular}

Tabel 8.8c. Verwachte kans op een beroep met veel zelfstandigheid van vervolgopleidingen voor MAVOleerlingen

\begin{tabular}{|c|c|c|c|c|c|}
\hline Vervolgopleiding & $\begin{array}{c}1 \\
\text { grootste }\end{array}$ & 2 & 3 & $\begin{array}{c}4 \\
\text { kleinste }\end{array}$ & $\begin{array}{l}\text { gemiddelde } \\
\text { positie }\end{array}$ \\
\hline & $\%$ & $\%$ & $\%$ & $\%$ & \\
\hline middelbaar agrarisch onderwijs & 36 & 23 & 22 & 19 & 2,2 \\
\hline middelbaar technisch onderwijs & 16 & 38 & 31 & 16 & 2,5 \\
\hline middelbaar economisch-administratief onderwijs & 34 & 20 & 21 & 25 & 2,4 \\
\hline middelbaar dienstverlenend/gezondheidszorg onderwijs & 14 & 19 & 26 & 41 & 2,9 \\
\hline
\end{tabular}

Tabel 8.8d. Verwachte kans op een beroep met veel zelfstandigheid van vervolgopleidingen voor HAVOleerlingen

\begin{tabular}{|c|c|c|c|c|c|c|c|}
\hline Vervolgopleiding & $\begin{array}{c}1 \\
\text { grootste }\end{array}$ & 2 & 3 & 4 & 5 & $\begin{array}{c}6 \\
\text { kleinste }\end{array}$ & $\begin{array}{c}\text { gemiddelde } \\
\text { positie }\end{array}$ \\
\hline & $\%$ & $\%$ & $\%$ & $\%$ & $\%$ & $\%$ & \\
\hline hoger pedagogisch onderwijs & 12 & 13 & 15 & 13 & 11 & 36 & 4,1 \\
\hline hoger agrarisch onderwijs & 29 & 16 & 16 & 15 & 15 & 9 & 3,0 \\
\hline hoger technisch onderwijs & 10 & 22 & 18 & 21 & 16 & 13 & 3,5 \\
\hline hoger economisch onderwijs & 23 & 16 & 14 & 15 & 19 & 13 & 3,3 \\
\hline hoger sociaal-cultureel onderwijs & 12 & 21 & 18 & 20 & 16 & 14 & 3,5 \\
\hline hoger gezondheidszorgonderwijs & 14 & 13 & 19 & 17 & 24 & 14 & 3,7 \\
\hline
\end{tabular}


$-150-$

Tabel 8.8e. Verwachte kans op een beroep met veel zelfstandigheid van vervolgopleidingen voor VWOleerlingen

\begin{tabular}{|c|c|c|c|c|c|c|c|c|}
\hline Vervolgopleiding & $\begin{array}{c}1 \\
\text { grootste }\end{array}$ & 2 & 3 & 4 & 5 & 6 & $\begin{array}{c}7 \\
\text { kleinste }\end{array}$ & $\begin{array}{l}\text { gemiddelde } \\
\text { positie }\end{array}$ \\
\hline & $\%$ & $\%$ & $\%$ & $\%$ & $\%$ & $\%$ & $\%$ & \\
\hline letteren & 13 & 12 & 14 & 15 & 14 & 12 & 20 & 4,2 \\
\hline agrarische wetenschappen & 20 & 15 & 16 & 14 & 15 & 12 & 8 & 3,6 \\
\hline technische wetenschappen & 13 & 18 & 15 & 16 & 19 & 10 & 9 & 3,8 \\
\hline economie & 18 & 16 & 14 & 19 & 11 & 15 & 6 & 3,6 \\
\hline rechten & 13 & 16 & 16 & 9 & 18 & 13 & 17 & 4,1 \\
\hline sociale wetenschappen & 9 & 14 & 13 & 17 & 13 & 23 & 12 & 4,3 \\
\hline medische wetenschappen & 12 & 11 & 12 & 10 & 11 & 16 & 29 & 4,6 \\
\hline
\end{tabular}




\section{DE KEUZE NA HET BASISONDERWIJS EN DE VAKKENPAKKETKEUZE IN HET ALGEMEEN VOORTGEZET ONDERWIJS}

Tabel 10.6a. Redenen voor het al dan niet kiezen van het vak frans door MAVO- en HAVO/VWOleerlingen naar geslacht

\begin{tabular}{|c|c|c|c|c|c|c|c|c|}
\hline \multirow{3}{*}{ Redenen } & \multicolumn{4}{|c|}{ wel frans kiezen } & \multicolumn{4}{|c|}{ geen frans kiezen } \\
\hline & \multicolumn{2}{|c|}{ MAVO } & \multicolumn{2}{|c|}{ HAVO/VWO } & \multicolumn{2}{|c|}{ MAVO } & \multicolumn{2}{|c|}{ HAVO/VWO } \\
\hline & j & m & j & m & j & $\mathrm{m}$ & j & $\mathrm{m}$ \\
\hline & $\%$ & $\%$ & $\%$ & $\%$ & $\%$ & $\%$ & $\%$ & $\%$ \\
\hline mijn cijfers voor dit vak & 51 & 54 & 49 & 43 & 36 & 32 & 42 & 49 \\
\hline of ik dit vak leuk vind & 51 & 61 & 68 & 60 & 24 & 26 & 34 & 39 \\
\hline $\begin{array}{l}\text { of ik dit vak moeilijk of } \\
\text { makkelijk vind } \\
\text { of mijn vrienden/vriendinnen }\end{array}$ & 18 & 25 & 24 & 30 & 37 & 41 & 45 & 48 \\
\hline $\begin{array}{l}\text { dit vak ook kiezen } \\
\text { of ik een leuke docent voor }\end{array}$ & 2 & 3 & - & - & 1 & 1 & - & 1 \\
\hline $\begin{array}{l}\text { dit vak krijg } \\
\text { of ik dit vak nodig heb voor de vervolg- }\end{array}$ & 3 & 4 & 5 & 1 & 3 & 7 & 4 & 3 \\
\hline $\begin{array}{l}\text { opleiding die ik hierna wil volgen } \\
\text { of ik heb dit vak nodig heb voor het beroep }\end{array}$ & 37 & 34 & 21 & 29 & 23 & 25 & 26 & 30 \\
\hline $\begin{array}{l}\text { dat ik wil uitoefenen } \\
\text { of dit vak past bij de andere vakken }\end{array}$ & 32 & 33 & 25 & 16 & 19 & 20 & 15 & 15 \\
\hline die ik denk te gaan kiezen & 12 & 4 & 9 & 15 & 5 & 8 & 9 & 6 \\
\hline $\begin{array}{l}\text { de mening van mijn ouders/verzorgers } \\
\text { de mening van mijn vrienden/ }\end{array}$ & 6 & 3 & 7 & 5 & 4 & 6 & 2 & 1 \\
\hline vriendinnen & 5 & - & - & - & 1 & 1 & - & - \\
\hline de mening van mijn docenten/dekaan & 7 & 5 & 2 & 8 & 6 & 8 & 7 & 9 \\
\hline andere redenen & 14 & 10 & 13 & 12 & 16 & 11 & 18 & 14 \\
\hline$N$ & 41 & 151 & 59 & 247 & 302 & 195 & 341 & 265 \\
\hline
\end{tabular}


Tabel 10.6b. Redenen voor het al dan niet kiezen van het vak geschiedenis door MAVO- en HAVO/VWOleerlingen naar geslacht

\begin{tabular}{|c|c|c|c|c|c|c|c|c|}
\hline \multirow{3}{*}{ Redenen } & \multicolumn{4}{|c|}{ wel geschiedenis kiezen } & \multicolumn{4}{|c|}{ geen geschiedenis kiezen } \\
\hline & \multicolumn{2}{|c|}{ MAVO } & \multicolumn{2}{|c|}{ HAVO/VWO } & \multicolumn{2}{|c|}{ MAVO } & \multicolumn{2}{|c|}{ HAVO/VWC } \\
\hline & j & $\mathrm{m}$ & $\mathrm{j}$ & m & j & $\mathrm{m}$ & j & $\mathrm{m}$ \\
\hline & $\%$ & $\%$ & $\%$ & $\%$ & $\%$ & $\%$ & $\%$ & $\%$ \\
\hline mijn cijfers voor dit vak & 38 & 34 & 47 & 44 & 26 & 32 & 17 & 30 \\
\hline of ik dit vak leuk vind & 70 & 56 & 78 & 78 & 40 & 32 & 27 & 44 \\
\hline $\begin{array}{l}\text { of ik dit vak moeilijk of } \\
\text { makkelijk vind }\end{array}$ & 42 & 41 & 59 & 55 & 26 & 43 & 24 & 36 \\
\hline of mijn vrienden/vriendinnen & & & & & & & & \\
\hline $\begin{array}{l}\text { dit vak ook kiezen } \\
\text { of ik een leuke docent voor }\end{array}$ & - & - & - & - & - & - & 1 & 0 \\
\hline dit vak krijg & 12 & 8 & 12 & 2 & 7 & 8 & 2 & 2 \\
\hline $\begin{array}{l}\text { of ik dit vak nodig heb voor de vervolg- } \\
\text { opleiding die ik hierna wil volgen }\end{array}$ & 15 & 25 & 9 & 21 & 23 & 22 & 37 & 32 \\
\hline of ik dit vak nodig heb voor het beroep & & & & & & & & \\
\hline $\begin{array}{l}\text { dat ik wil uitoefenen } \\
\text { of dit vak past bij de andere vakken }\end{array}$ & 8 & 19 & 5 & 7 & 19 & 21 & 29 & 26 \\
\hline die ik denk te gaan kiezen & 13 & 15 & 14 & 10 & 7 & 6 & 14 & 14 \\
\hline $\begin{array}{l}\text { de mening van mijn ouders/verzorgers } \\
\text { de mening van mijn vrienden/ }\end{array}$ & 2 & 2 & 4 & 1 & 5 & 3 & 2 & 2 \\
\hline $\begin{array}{l}\text { vriendinnen } \\
\text { vall }\end{array}$ & - & 2 & - & - & 1 & 0 & & \\
\hline de mening van mijn docenten/dekaan & 1 & 3 & 8 & 5 & 4 & 2 & 3 & 5 \\
\hline andere redenen & 18 & 16 & 19 & 11 & 18 & 16 & 24 & 10 \\
\hline $\mathrm{N}$ & 86 & 79 & 99 & 178 & 257 & 267 & 302 & 334 \\
\hline
\end{tabular}




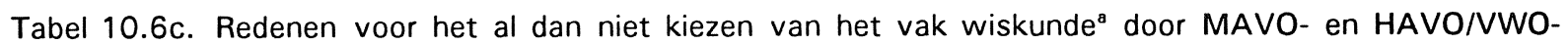
leerlingen naar geslacht

\begin{tabular}{|c|c|c|c|c|c|c|c|c|}
\hline \multirow{3}{*}{ Redenen } & \multicolumn{4}{|c|}{ wel wiskunde kiezen } & \multicolumn{4}{|c|}{ geen wiskunde kiezen } \\
\hline & \multicolumn{2}{|c|}{ MAVO } & \multicolumn{2}{|c|}{ HAVO/VWO } & \multicolumn{2}{|c|}{ MAVO } & \multicolumn{2}{|c|}{ HAVO/VWO } \\
\hline & j & $\mathrm{m}$ & $\mathrm{j}$ & $\mathrm{m}$ & $\mathrm{j}$ & $\mathrm{m}$ & j & $\mathrm{m}$ \\
\hline & $\%$ & $\%$ & $\%$ & $\%$ & $\%$ & $\%$ & $\%$ & $\%$ \\
\hline mijn cijfers voor dit vak & 34 & 37 & 29 & 29 & 34 & 36 & 31 & 42 \\
\hline of ik dit vak leuk vind & 36 & 38 & 34 & 30 & 22 & 25 & 18 & 22 \\
\hline $\begin{array}{l}\text { of ik dit vak moeilijk of } \\
\text { makkelijk vind }\end{array}$ & 25 & 25 & 15 & 20 & 45 & 47 & 57 & 64 \\
\hline of mijn vrienden/vriendinnen & & & & & & & & \\
\hline dit vak ook kiezen & 1 & 1 & - & - & - & 3 & & 1 \\
\hline $\begin{array}{l}\text { of ik een leuke docent voor } \\
\text { dit vak krijg }\end{array}$ & 3 & 5 & 1 & 1 & 5 & 7 & - & - \\
\hline of ik dit vak nodig heb voor de vervolg- & & & & & & & & \\
\hline $\begin{array}{l}\text { opleiding die ik hierna wil volgen } \\
\text { of ik dit vak nodig heb voor het beroep }\end{array}$ & 58 & 53 & 58 & 51 & 28 & 31 & 33 & 25 \\
\hline $\begin{array}{l}\text { dat ik wil uitoefenen } \\
\text { of dit vak past bii de andere vakken }\end{array}$ & 44 & 40 & 41 & 25 & 17 & 18 & 14 & 14 \\
\hline die ik denk te gaan kiezen & 18 & 13 & 28 & 31 & 9 & 8 & 9 & 7 \\
\hline de mening van mijn ouders/verzorgers & 6 & 6 & 4 & 5 & 6 & - & 2 & 2 \\
\hline vriendinnen & 1 & - & - & - & 6 & 3 & - & - \\
\hline de mening van mijn docenten/dekaan & 4 & 3 & 2 & 7 & - & 7 & 17 & 14 \\
\hline andere redenen & 1 & 7 & 7 & 7 & 3 & 15 & 13 & 9 \\
\hline $\mathrm{N}$ & 303 & 232 & 225 & 121 & 40 & 114 & 175 & 391 \\
\hline
\end{tabular}


Tabel 10.6d. Redenen voor het al dan niet kiezen van het vak natuurkunde door MAVO- en HAVO/VWOleerlingen naar geslacht

\begin{tabular}{|c|c|c|c|c|c|c|c|c|}
\hline \multirow{3}{*}{ Redenen } & \multicolumn{4}{|c|}{ wel natuurkunde kiezen } & \multicolumn{4}{|c|}{ geen natuurkunde kiezen } \\
\hline & \multicolumn{2}{|c|}{ MAVO } & \multicolumn{2}{|c|}{ HAVO/VWO } & \multicolumn{2}{|c|}{ MAVO } & \multicolumn{2}{|c|}{ HAVO/VWO } \\
\hline & j & $\mathrm{m}$ & j & $\mathrm{m}$ & j & $\mathrm{m}$ & j & m \\
\hline & $\%$ & $\%$ & $\%$ & $\%$ & $\%$ & $\%$ & $\%$ & $\%$ \\
\hline mijn cijfers voor dit vak & 29 & 28 & 28 & 29 & 26 & 32 & 34 & 47 \\
\hline of ik dit vak leuk vind & 36 & 21 & 42 & 35 & 30 & 26 & 28 & 31 \\
\hline $\begin{array}{l}\text { of ik dit vak moeilijk of } \\
\text { makkelijk vind }\end{array}$ & 25 & 32 & 17 & 23 & 33 & 45 & 41 & 62 \\
\hline of mijn vrienden/vriendinnen & & & & & & & & \\
\hline $\begin{array}{l}\text { dit vak ook kiezen } \\
\text { of ik een leuke docent voor }\end{array}$ & 2 & - & - & - & 1 & 2 & - & 1 \\
\hline $\begin{array}{l}\text { dit vak krijg } \\
\text { of ik dit vak nodia heb voor de vervola- }\end{array}$ & 1 & - & 1 & - & 3 & 8 & 2 & 1 \\
\hline $\begin{array}{l}\text { of ik dit vak nodig heb voor de vervolg- } \\
\text { opleiding die ik hierna wil volgen } \\
\text { of ik dit vak nodig heb voor het beroep }\end{array}$ & 54 & 62 & 59 & 57 & 20 & 18 & 37 & 24 \\
\hline $\begin{array}{l}\text { dat ik wil uitoefenen } \\
\text { of dit vak past bij de andere vakken }\end{array}$ & 43 & 43 & 39 & 33 & 15 & 13 & 20 & 12 \\
\hline die ik denk te gaan kiezen & 24 & 18 & 24 & 28 & 8 & 7 & 11 & 5 \\
\hline $\begin{array}{l}\text { de mening van mijn ouders/verzorgers } \\
\text { de mening van mijn vrienden/ }\end{array}$ & 3 & 6 & 3 & 5 & 8 & 3 & - & 2 \\
\hline vriendinnen & 0 & - & - & - & 1 & 1 & - & - \\
\hline de mening van mijn docenten/dekaan & 3 & 8 & - & 6 & 6 & 6 & 10 & 9 \\
\hline andere redenen & 3 & 7 & 6 & 1 & 14 & 16 & 12 & 6 \\
\hline $\mathrm{N}$ & 209 & 76 & 235 & 137 & 133 & 271 & 165 & 375 \\
\hline
\end{tabular}


Tabel 10.6e. Redenen voor het al dan niet kiezen van het vak economie door MAVO- en HAVO/VWOleerlingen naar geslacht

\begin{tabular}{|c|c|c|c|c|c|c|c|c|}
\hline \multirow{3}{*}{ Redenen } & \multicolumn{4}{|c|}{ wel economie kiezen } & \multicolumn{4}{|c|}{ geen economie kiezen } \\
\hline & \multicolumn{2}{|c|}{ MAVO } & \multicolumn{2}{|c|}{ HAVO/VWO } & \multicolumn{2}{|c|}{ MAVO } & \multicolumn{2}{|c|}{ HAVO/VWO } \\
\hline & j & $\mathrm{m}$ & j & $\mathrm{m}$ & j & $m$ & j & $\mathrm{m}$ \\
\hline & $\%$ & $\%$ & $\%$ & $\%$ & $\%$ & $\%$ & $\%$ & $\%$ \\
\hline mijn cijfers voor dit vak & 31 & 30 & 16 & 16 & 29 & 30 & 16 & 19 \\
\hline $\begin{array}{l}\text { of ik dit vak leuk vind } \\
\text { of ik dit vak moeiliik of }\end{array}$ & 37 & 34 & 30 & 42 & 30 & 17 & 27 & 37 \\
\hline $\begin{array}{l}\text { makkelijk vind } \\
\text { of mijn vrienden/vriendinnen }\end{array}$ & 18 & 23 & 11 & 18 & 22 & 38 & 20 & 37 \\
\hline $\begin{array}{l}\text { dit vak ook kiezen } \\
\text { of ik een leuke docent voor }\end{array}$ & - & 2 & - & - & 4 & 1 & 2 & 1 \\
\hline $\begin{array}{l}\text { dit vak krijg } \\
\text { of ik dit vak nodig heb voor de vervolg- }\end{array}$ & 4 & 4 & 3 & 0 & 9 & 2 & 1 & 4 \\
\hline $\begin{array}{l}\text { opleiding die ik hierna wil volgen } \\
\text { of ik dit vak nodig heb voor het beroep }\end{array}$ & 56 & 48 & 54 & 48 & 23 & 22 & 28 & 35 \\
\hline $\begin{array}{l}\text { dat ik wil uitoefenen } \\
\text { of dit vak past bij de andere vakken }\end{array}$ & 39 & 33 & 34 & 35 & 21 & 19 & 29 & 23 \\
\hline die ik denk te gaan kiezen & 17 & 12 & 30 & 27 & 8 & 6 & 12 & 6 \\
\hline $\begin{array}{l}\text { de mening van mijn ouders/verzorgers } \\
\text { de mening van mijn vrienden/ }\end{array}$ & 9 & 6 & 3 & 4 & 4 & 4 & 3 & 3 \\
\hline vriendinnen & 0 & - & 1 & - & 1 & 1 & 1 & 1 \\
\hline de mening van mijn docenten/dekaan & 4 & 5 & 7 & 11 & 7 & 5 & 8 & 11 \\
\hline andere redenen & 8 & 6 & 18 & 6 & 10 & 12 & 26 & 17 \\
\hline $\mathrm{N}$ & 196 & 169 & 212 & 256 & 146 & 177 & 188 & 256 \\
\hline
\end{tabular}




\section{DE KEUZE NA DE HUIDIGE OPLEIDING}

Tabel 11.2a. Keuze voor een vervolgopleiding door VBO-Techniek-leerlingen naar geslacht

\begin{tabular}{lrr} 
Opleidingskeuze & jongens & meisjes \\
\hline & $\%$ & $\%$ \\
MAVO & 1 & 2 \\
agrarische opleiding in MBO/kort MBO & 2 & 4 \\
technische of laboratorium opleiding in MBO/kort MBO & 82 & 21 \\
medische opleiding in MBO/kort MBO & 0 & - \\
economisch-administratieve opleiding in MBO/kort MBO & 1 & 1 \\
handelsopleiding in MBO/kort MBO & 2 & 32 \\
dienstverlenend/verzorgende opleiding in MBO/kort MBO & 6 & 6 \\
politie-opleiding of militaire opleiding & 3 & 3 \\
andere opleiding & & 29 \\
$\mathrm{~N}$ & 190 & \\
Cramer's V = 0,62* & & \\
$*$ * significant 5\%-niveau; ** = significant 1\%-niveau & &
\end{tabular}

Tabel 11.2b. Keuze voor een vervolgopleiding door VBO-Overig-leerlingen naar geslacht

\begin{tabular}{lrr}
\hline Opleidingskeuze & jongens & meisjes \\
& $\%$ & $\%$ \\
MAVO & 4 & 3 \\
agrarische opleiding in MBO/kort MBO & 27 & 8 \\
technische of laboratoriumopleiding in MBO/kort MBO & 14 & 2 \\
medische opleiding in MBO/kort MBO & - & 10 \\
economisch-administratieve opleiding in MBO/kort MBO & 31 & 3 \\
handelsopleiding in MBO/kort MBO & 10 & 2 \\
dienstverlenend/verzorgende opleiding in MBO/kort MBO & 5 & 1 \\
politie-opleiding of militaire opleiding & 9 & 188 \\
andere opleiding & 1 & \\
$N$ & 67 & \\
Cramer's V = 0,57* & & \\
* = significant 5\%-niveau; * = significant 1\%-niveau & & \\
\end{tabular}


Tabel 11.2c. Keuze voor een vervolgopleiding door MAVO-leerlingen naar geslacht

\begin{tabular}{lrr}
\hline Opleidingskeuze & jongens & meisjes \\
\hline & $\%$ & $\%$ \\
HAVO & 35 & 38 \\
agrarische opleiding in MBO/kort MBO & 1 & 1 \\
technische of laboratoriumopleiding in MBO/kort MBO & 27 & 4 \\
medische opleiding in MBO/kort MBO & 1 & 11 \\
economisch-administratieve opleiding in MBO/kort MBO & 15 & 3 \\
handelsopleiding in MBO/kort MBO & 8 & 3 \\
dienstverlenend/verzorgende opleiding in MBO/kort MBO & 4 & 6 \\
politie-opleiding of militaire opleiding & 6 & 283 \\
andere opleiding & 4 & \\
N & 277 & \\
Cramer's V = 0,47** & & \\
* significant 5\%-niveau; * significant 1\%-niveau & & \\
\end{tabular}

Tabel 11.2d. Keuze voor een vervolgopleiding door HAVO-leerlingen naar geslacht

Opleidingskeuze jongens meisjes

\begin{tabular}{|c|c|c|}
\hline & $\%$ & $\%$ \\
\hline VWO & 22 & 22 \\
\hline agrarische opleiding in $\mathrm{MBO} /$ kort $\mathrm{MBO}$ & - & - \\
\hline technische of laboratorium opleiding in $\mathrm{MBO} /$ kort $\mathrm{MBO}$ & 3 & 0 \\
\hline medische opleiding in $\mathrm{MBO} /$ kort $\mathrm{MBO}$ & - & 5 \\
\hline economisch-administratieve opleiding in $\mathrm{MBO} /$ kort $\mathrm{MBO}$ & 11 & 8 \\
\hline handelsopleiding in $\mathrm{MBO} /$ kort $\mathrm{MBO}$ & 2 & 0 \\
\hline dienstverlenend/verzorgende opleiding in $\mathrm{MBO} /$ kort $\mathrm{MBO}$ & - & 5 \\
\hline politie-opleiding of militaire opleiding & 6 & 3 \\
\hline pedagogische opleiding in het $\mathrm{HBO}$ & 3 & 12 \\
\hline agrarische opleiding in het $\mathrm{HBO}$ & 4 & 2 \\
\hline technische of laboratorium opleiding in het $\mathrm{HBO}$ & 17 & 4 \\
\hline medische opleiding in het $\mathrm{HBO}$ & 3 & 5 \\
\hline economische opleiding in het $\mathrm{HBO}$ & 20 & 9 \\
\hline sociale opleiding in het $\mathrm{HBO}$ & - & 2 \\
\hline kunstopleiding in het $\mathrm{HBO}$ & 7 & 9 \\
\hline andere opleiding & 5 & 15 \\
\hline $\mathrm{N}$ & 196 & 241 \\
\hline Cramer's $V=0,45^{* *}$ & & \\
\hline
\end{tabular}


Tabel 11.2e. Keuze voor een vervolgopleiding door VWO-leerlingen naar geslacht

\begin{tabular}{|c|c|c|}
\hline Opleidingskeuze & jongens & meisjes \\
\hline & $\%$ & $\%$ \\
\hline pedagogische opleiding in het $\mathrm{HBO}$ & 1 & 2 \\
\hline agrarische opleiding in het $\mathrm{HBO}$ & 1 & 2 \\
\hline technische of laboratorium opleiding in het $\mathrm{HBO}$ & 9 & 2 \\
\hline medische opleiding in het $\mathrm{HBO}$ & 2 & 8 \\
\hline economische opleiding in het $\mathrm{HBO}$ & 8 & 11 \\
\hline sociale opleiding in het $\mathrm{HBO}$ & 1 & 4 \\
\hline kunstopleiding in het HBO & 5 & 2 \\
\hline universitaire opleiding in de letteren & 6 & 10 \\
\hline universitaire opleiding in de agrarische wetenschappen & 1 & - \\
\hline universitaire opleiding in de technische wetenschappen & 29 & 7 \\
\hline universitaire studie in de medische wetenschappen & 8 & 18 \\
\hline universitaire opleiding in de economische wetenschappen & 14 & 5 \\
\hline universitaire opleiding in de rechten & 4 & 10 \\
\hline universitaire opleiding in de sociale wetenschappen & 1 & 12 \\
\hline andere opleiding & 9 & 9 \\
\hline $\mathrm{N}$ & 108 & 146 \\
\hline Cramer's $V=0,48^{* *}$ & & \\
\hline
\end{tabular}

Tabel 11.3. Keuze voor een beroep naar opleidingscategorie en geslacht

\begin{tabular}{|c|c|c|c|c|c|c|c|c|}
\hline \multirow[t]{2}{*}{ Beroepskeuze } & \multicolumn{2}{|c|}{ VBO-Techniek } & \multicolumn{2}{|c|}{ VBO-Overig } & \multicolumn{2}{|c|}{ MAVO } & \multicolumn{2}{|c|}{ HAVO/VWC } \\
\hline & j & $\mathrm{m}$ & j & $\mathrm{m}$ & j & $\mathrm{m}$ & j & m \\
\hline & $\%$ & $\%$ & $\%$ & $\%$ & $\%$ & $\%$ & $\%$ & $\%$ \\
\hline agrarisch beroep & 1 & - & 25 & 18 & 3 & - & 9 & - \\
\hline technisch beroep & 72 & 21 & 17 & 2 & 24 & - & 48 & 13 \\
\hline transport beroep & 8 & - & 5 & - & 14 & - & 7 & - \\
\hline medisch beroep & 1 & 39 & 2 & 14 & 3 & 23 & 22 & 33 \\
\hline economisch-administratief beroep & - & - & 6 & 16 & - & 6 & 7 & 17 \\
\hline handelsberoep & 3 & - & 28 & 4 & 13 & 8 & - & 16 \\
\hline dienstverlenend beroep & 11 & 34 & 7 & 34 & 17 & 54 & - & 13 \\
\hline veiligheidsberoep & 3 & - & 5 & 10 & 23 & 8 & 7 & - \\
\hline ander beroep & 1 & 5 & 4 & 1 & 3 & - & - & 8 \\
\hline $\mathrm{N}$ & 90 & 8 & 25 & 77 & 37 & 37 & 16 & 28 \\
\hline Cramer's V & & $2^{* *}$ & & $57^{* *}$ & & $68^{* *}$ & & 64 \\
\hline
\end{tabular}

